\title{
OREA
}

\section{Annual Report 2018}

Barbara Horejs (ed.) 


\section{OREA \\ Annual Report 2018}

Barbara Horejs (ed.) 


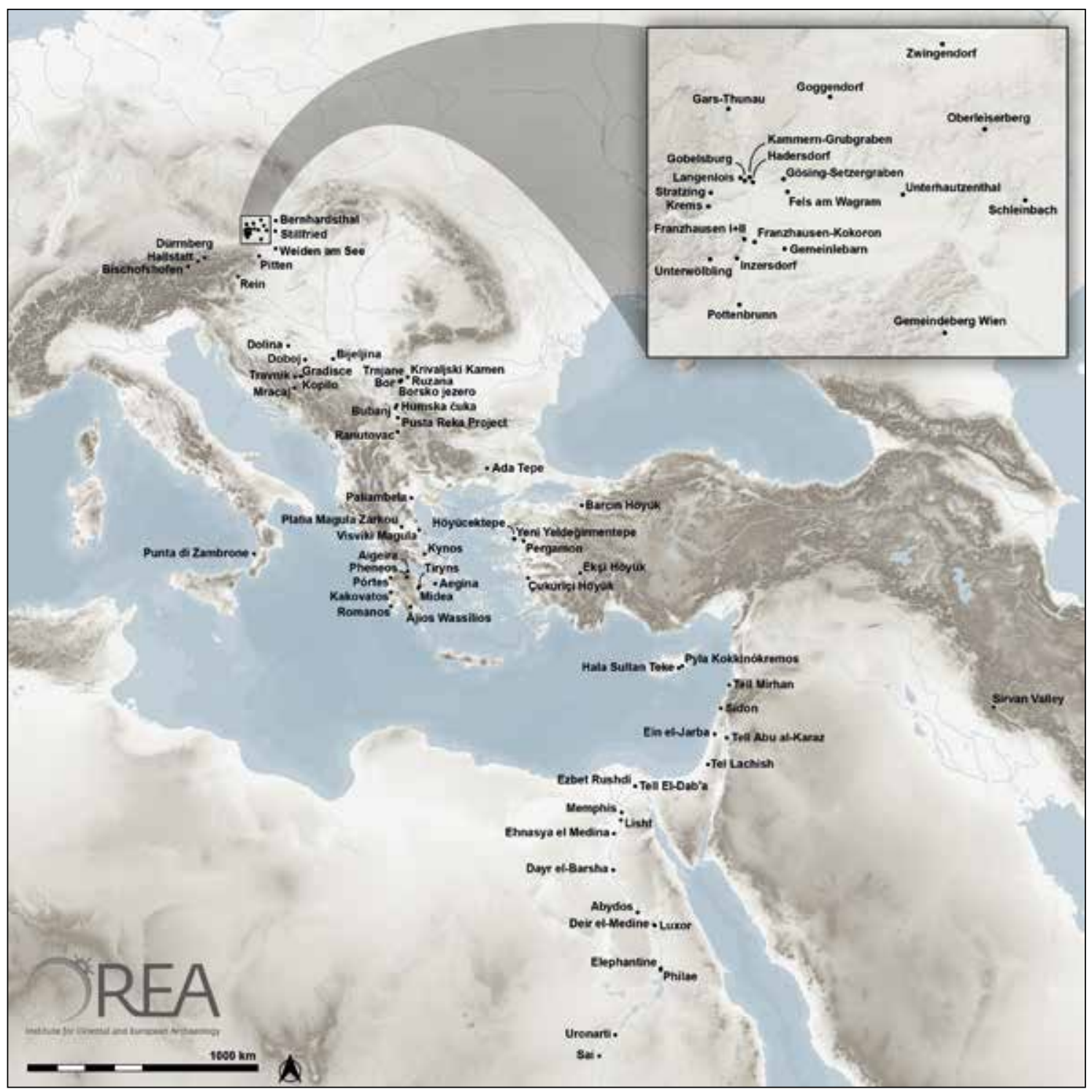

Fig. 1 Current research projects at OREA (2018-2019)

Report: Barbara Horejs (ed.) \& the OREA Team, OREA

Editing: Ulrike Schuh, Angela Schwab, Sophie Zimmermann

Language editing: Nicola Wood, Clare Burke

Layout: Angela Schwab

All rights reserved (C) OREA, Austrian Academy of Sciences 2019

ISBN: 978-3-903207-35-6 


\section{Contents}

OREA Mission Statement and Short Description - B. Horejs, D. Melman, U. Schuh, A. Schwab ....... 5

The Cluster 'Archaeology and Classics' - CLAC $\ldots \ldots \ldots \ldots \ldots \ldots \ldots \ldots \ldots \ldots \ldots \ldots \ldots$

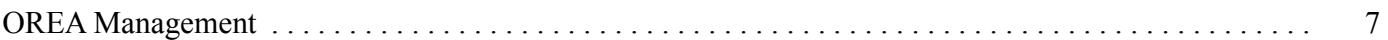

Research strategy. . . . . . . . . . . . . 10

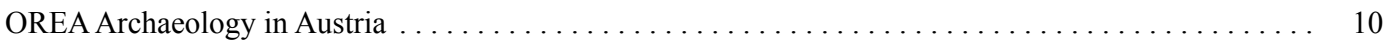

Promotion of young researchers, career development, gender and diversity in $2018 \ldots \ldots \ldots \ldots \ldots \ldots$

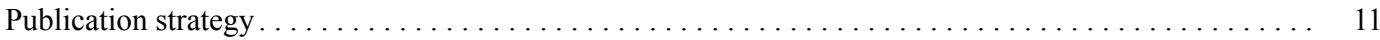

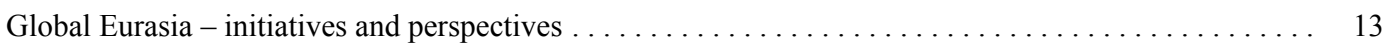

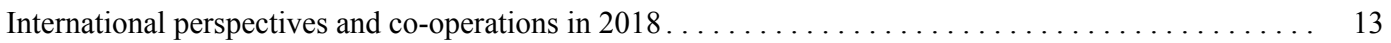

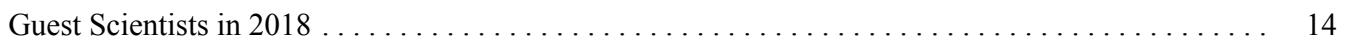

Turkey Scientific Initiative of the Austrian Academy of Sciences at OREA $\ldots \ldots \ldots \ldots \ldots \ldots \ldots$

High Impact National and International Outreach in 2018 - B. Horejs, A. Schwab. . . . . . . . . . 16

Gold and Bronze. Metals, Technologies and Networks in the Eastern Balkans during the Bronze Age, National Archaeological Museum in Sofia . . . . . . . . . . . . . . . . . . . . . . . . 16

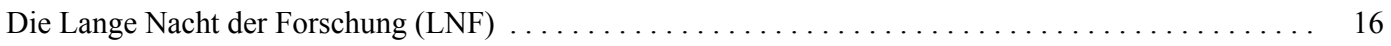

'Beyond Death: Exploring the uses of dead bodies, funerary objects, and burial spaces through time'

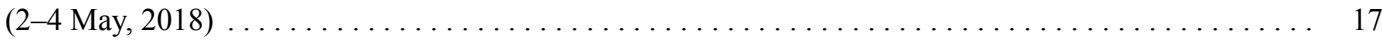

OREA at BE OPEN - Science \& Society Festival: 50 years of top-level research in Austria . . . . . . 18

Tag des Denkmals, Monuments Day 2018, 30 September $\ldots \ldots \ldots \ldots \ldots \ldots \ldots \ldots \ldots \ldots \ldots \ldots \ldots \ldots$

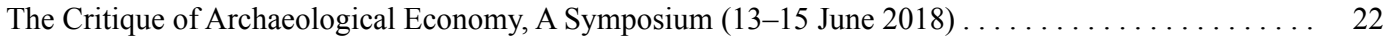

Genes, Isotopes and Artefacts: How should we interpret the movements of people throughout

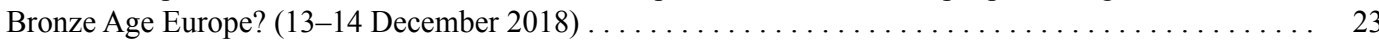

135 + 5 Jahre: 140 Jahre Prähistorische Forschungen an der Österreichischen Akademie der

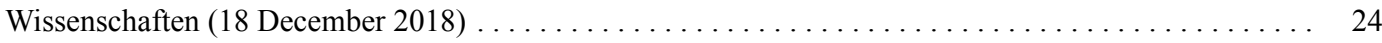

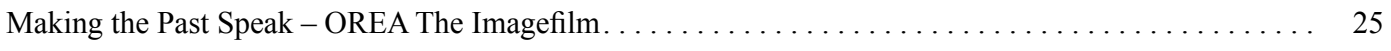

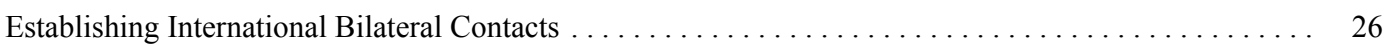

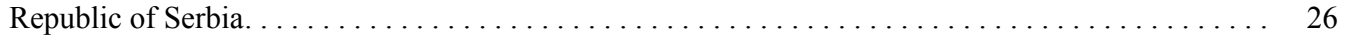

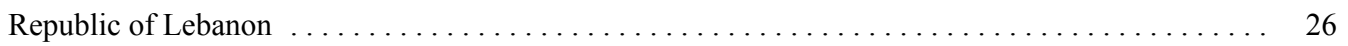

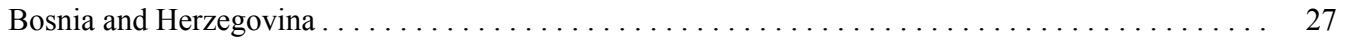

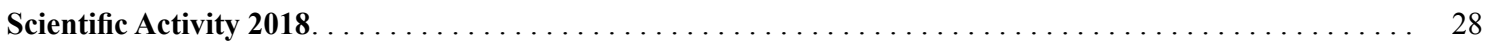

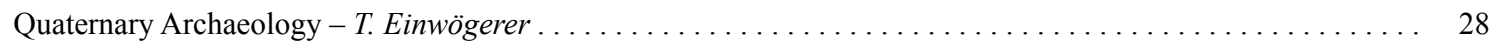

Prehistoric Phenomena - E. Alram-Stern, B. Horejs, Ch. Schwall, G. Brem, B. Wallner .............. 33

Prehistoric Identities - K. Rebay-Salisbury, D. Pany-Kucera, R. B. Salisbury, E. Perego, M. Fritzl,

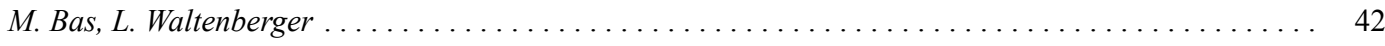

DEEPDEAD - Deploying the Dead: Artefacts and human bodies in socio-cultural transformations

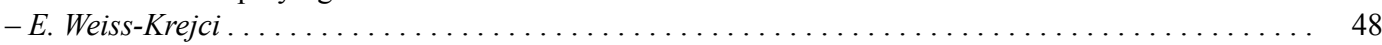

Levantine and Egyptian Histories - R. Gundacker, F. Höflmayer, A. Wüthrich $\ldots \ldots \ldots \ldots \ldots \ldots \ldots \ldots \ldots$ 


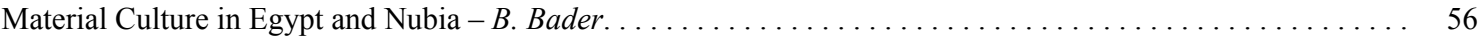

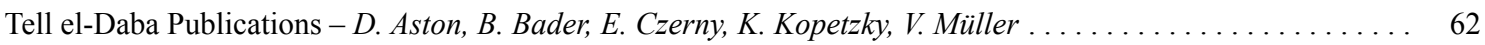

Mediterranean Economies - T. Bürge, L. Burkhardt, R. Jung, E. Kardamaki, K. Kopetzky, A. Rumolo. . . . . . . 67

The Mycenaean Aegean - B. Eder, E.Alram-Stern, J. Huber, A. Vött, M. Zavadil ................ 72

Urnfield Culture Networks - M. Gavranović, M. Griebl, B. Biederer. . . . . . . . . . . . . . . . . . 78

OREA Raw Material Lab - M. Brandl, C. Burke, G. Ruß-Popa........................ 87

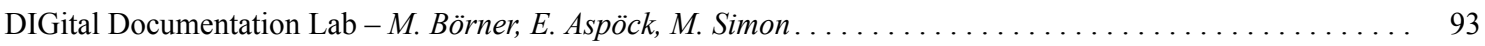

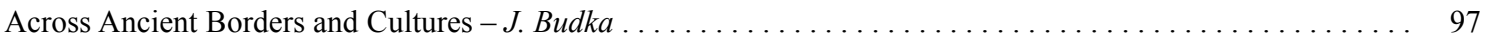

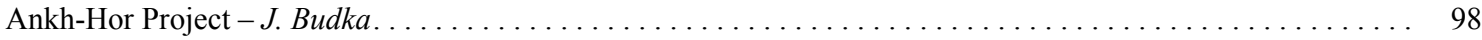

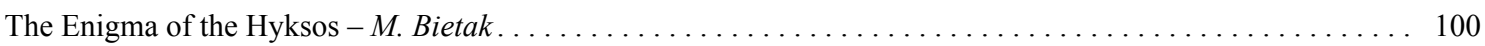

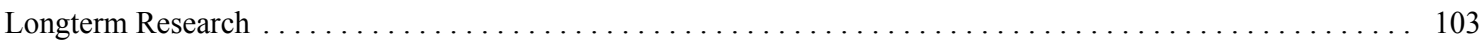

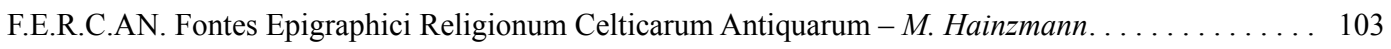

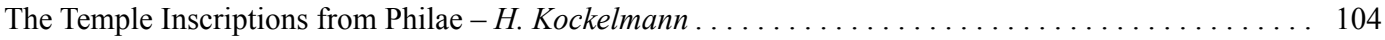

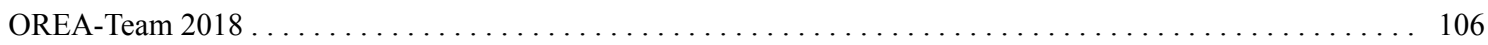

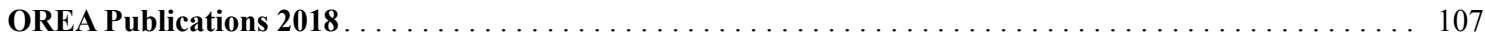




\section{OREA Mission Statement and Short Description}

The Institute for Oriental and European Archaeology (OREA), founded by uniting three Commissions partly going back to 1878 , covers essential prehistoric and early historical cultural developments from the Orient to Europe. This mission is reflected in research ranging from Europe, North Africa, as well as the Middle East in the context of World Archaeology. The Orient and Occident are frequently understood as counterpoints in different worlds and explored separately. In this research institute, these areas are deliberately considered a common cultural bracket for crucial advances of human (pre)history and are therefore explored together. The focus of basic research lies in the time horizon from the Quaternary, about 2.6 million years ago, to the transformation of societies into historical epochs in the first millennium BC.

Research methods include archaeological field work (excavations and surveys), material culture studies with diverse archaeometric methods, and interdisciplinary co-operations with a range of different disciplines, including archaeozoology, archaeobotanics, anthracology, biological anthropology, palaeogenetics, climatology, geoarchaeology and landscape modelling. The basic analysis and interpretation of early cultures lies at the core of research efforts, which aim to include all possible sources. The study of chronologies, art and early writing as well as a broad socio-cultural spectrum including religion, ideologies, economies and identities compliment research at the institute.

OREA focusses on the following research topics:

- Prehistory in the Orient \& Europe

- Archaeology from the Pleistocene to Early State Societies

- Environments \& Economies, Digital Archaeology

- Interdisciplinary Studies of Resources \& Identities

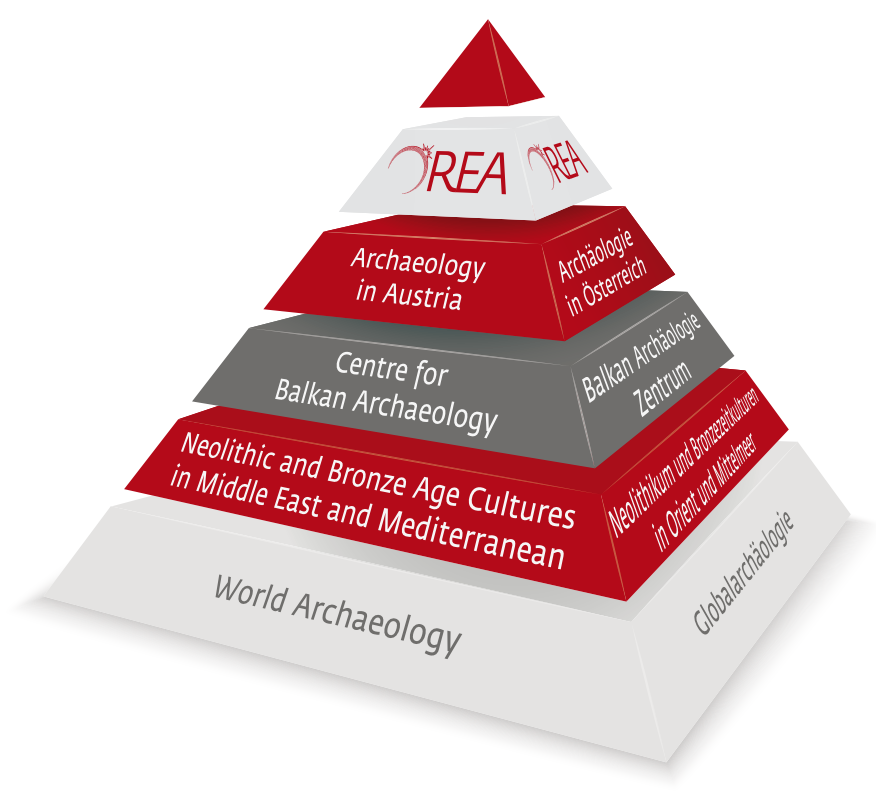

Fig. 2 Main scientific expertise at OREA (C OREA)

OREA researchers cover a wide range of disciplines from prehistoric archaeology, egyptology, sudanese archaeology, Near/Middle Eastern and early Greek archaeology to various philologies, anthropology and raw material studies. In 2018 about 70 OREA scientists were active in 
17 countries on three continents conducting field work at sites spanning from the Palaeolithic to the Bronze Age.

Targeted research on different priorities is concentrated in research groups spanning broad regions and designed to be trans-regional and diachronic. Research groups are being initiated and developed to pick up new trends in the research landscape and provide new impetus.

For ongoing national and international quality assurance as well as additional research funding, the institute strives for success in competitive third party funding. Current financial support is provided by the Austrian Research Fund (FWF), the ERC, the Marie Skłodowska-Curie programme and INSTAP as well as by the Austrian National Bank (ÖNB), the White Levy Fund, the City of Vienna, the County of Lower Austria and various private foundations. Altogether four ERC Grants (3 Starting, 1 Advanced) and four FWF START prizes mark OREA as one of the leading institutes in the international field of archaeology.

The institute publishes five publication series and two international journals. The publications reflect the core research areas and comply with the highest scientific standards through international evaluation procedures and advisory boards.

\section{The Cluster 'Archaeology and Classics'-CLAC}

OREA is now part of the Cluster for Archaeology and Classics of the Austrian Academy of Sciences. The Cluster Archaeology and Classics (CLAC) was founded at the Austrian Academy of Sciences with the aim of consolidating the already existing research excellence in these professional disciplines, and of increasing potential for innovation. CLAC constitutes the parent organisation for the Institute for the Study of Antient Culture (IKAnt), the Institute for Oriental and European Archaeology (OREA), as well as the Austrian Archaeological Institute (ÖAI). These institutes, with significant strategic priorities, cover the entire curriculum and the diversity of methods of their disciplines. The chronological range of the expertise extends from the Quaternary period up until the modern era.

With the foundation of the cluster, the largest archaeological research association of Austria, with approximately 190 colleagues in a total of 30 groups, came into being. The official kick-off event on October 9, 2018 was co-organized by the three member institutes of the cluster in a very fruitful meeting triggering vivid scientific discussions.

In addition, via the establishment of the Archaeological Council (Archäologischer Rat) at the AAS in 2016 with the involvement of complementary university institutions, museums, Austrian archaeological institutions as well as the Federal Monuments Office (as advisor), an instrument has been created for the management and organisation of archaeological research in Austria.

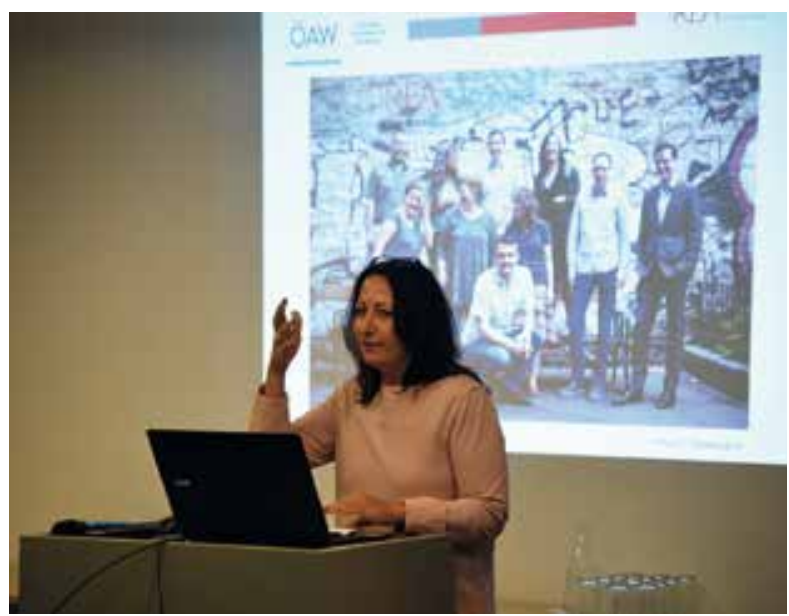

Fig. 3 B. Horejs at the CLAC Kick-off, 9 October 2018

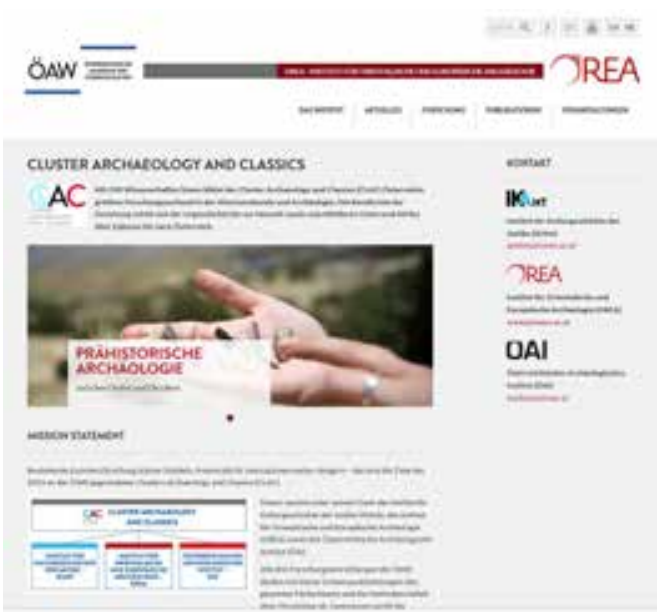

Fig. 4 https://www.orea.oeaw.ac.at/clac/ 


\section{OREA Management}

In spring 2018 Mario Gavranović took over the role of the deputy director of OREA. Administrational support in 2018 was provided additionally by Bibiana Dernec and Valentin Jovanovic.

The definition of research initiatives within OREA is as follows:

\section{- Research groups}

Innovative research on different priorities within OREA is focused in research groups - period independently/diachronic - according to the respective topic. The development of research groups was directly coupled to the structure of the new institute in 2013 and led to a fundamentally new research structure, now established and consolidated. They are the basic structure within OREA in order to carry out successful international and interdisciplinary research in a structured team framework, which also specifically integrates and promotes young researchers. The groups are constantly evolving as a dynamic element and initiated to set new impulses in the research landscape. They are implemented for a limited period and have to undergo evaluation according to recognised quality assurance criteria.

\section{- Long-Term research \& Platforms}

Traditional research priorities are bundled in the form of long-term research projects. This relates primarily to long-term commitments to editions, publication of old excavations' material etc. The Urnfield Culture Networks project is OREA's highly successfully evaluated long-term research project. Mario Gavranović took over the function as principal investigator after the retirememnt of Michaela Lochner in Spring 2018.

The platform History of Archaeology irregularly brings together colleagues working on different topics not only concerning the history of archaeology and the biographies of archaeologists but also dealing with questions of history of art. Only sporadic lectures or workshops are organized. Research is manifold and covers amongst other things research into the history of the former Kommissionen, the impact of Egyptian art on $19^{\text {th }}$ century painting and studies on Heinrich Schliemann. The platform integrates researchers from OREA and different Austrian institutions as well as freelancers.

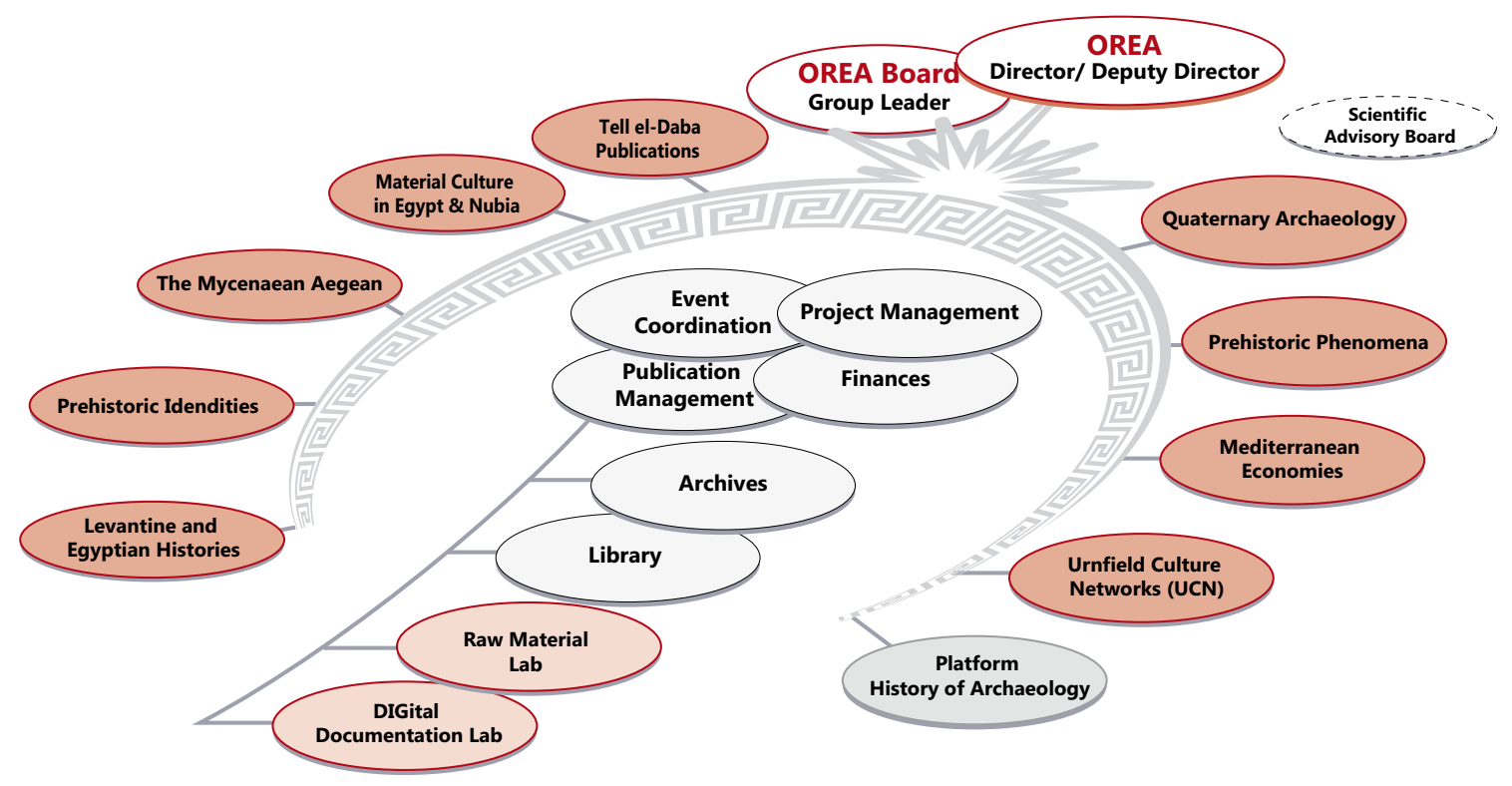

Fig. 5 Organigram of OREA institute 2018 


\section{- Laboratories}

Two laboratories are now supporting the research activities at OREA. They have been established as analytical and documentative service devices.

The Raw Material Lab (M. Brandl) ist interacting with all research programs dealing with raw material sources, economic development and trade routes, and helps to trace and identify their sources and distribution routes.

The DIGital Documentation Lab (M. Börner) has been developed out of the former Digital Archaeology group and is now focussing on all the digital support archaeological research might need - professional excavation engineering and provision of computer-assisted methods for capturing, processing and preparing research data. The lab is equally working together with all research groups at OREA and the Austrian Centre for Digital Humanities of the AAS.

\section{- The OREA Archives}

Following the fusion of the former Commissions OREA took over the responsibility for the hitherto accumulated and rather divers archives. Fortunately the spatial situation of OREA could be highly improved by moving into a new office infrastructure in summer 2016, which also guaranteed very good storage conditions for the valuable and heterogenous files and objects. This change of location and given the UV-protected, largely dust-free storage environment a complete survey of the portfolio was undertaken. New standards of organisation and administration updated the accessibility to a $21^{\text {st }}$-century state-of-the-art procedure. The reorganisation of the archives has been completed recently and the responsibility was assumed by Eva Alram, Michael Brandl, Mario Gavranović and Karin Kopetzky. The new and detailed breakdown of the inventory is complemented by an on-going digitization of the analogue data for long-term-storage at the repositories of the Austrian Academy of Sciences.

Deailed information on the archives can be found in the Annual Report 2017 (https://www. orea.oeaw.ac.at/fileadmin/Institute/OREA/pdf/Publikationen/OREA_AnnualReport_2017.pdf).

The following archives are accessible at OREA:

The lithic raw material collection at OREA (responsible: M. Brandl) detailed information in the Annual Report 2017, 13-14.

The Urnfield Culture archive (responsible: M. Gavranović) includes documentation of excavations at Franzhausen-Kokoron, Inzersdorf ob der Traisen, Gars/ Thunau; detailed information in the Annual Report 2017, 15.

Archive of the Fritz Schachermeyr Collection (responsible: E. Alram) detailed information in the Annual Report 2017, 15.

The Egyptian excavations' archive (responsible: K. Kopetzky) includes documentation of excavations at Tell el-Daba, the Assasif and Sayala; detailed information in the Annual Report 2017, 15-16. 


\section{OREA Research Group Leaders} and Heads of Labs

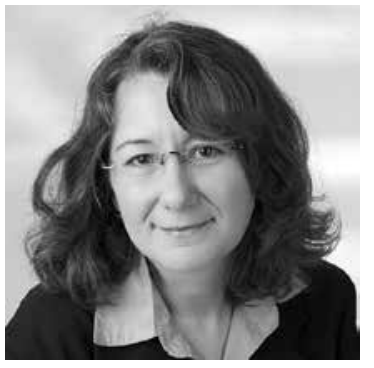

Material Culture in Egypt \& Nubia The Mycenaean Aegean Bettina Bader

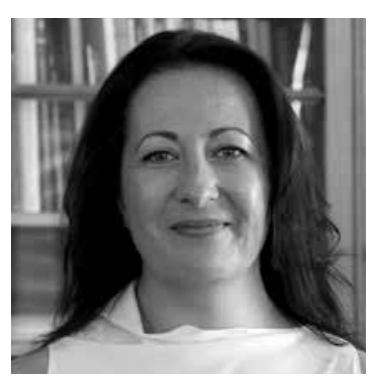

Prehistoric Phenomena Barbara Horejs

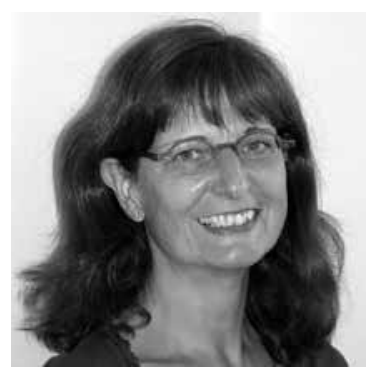

Tell el-Daba Publications Vera Müller

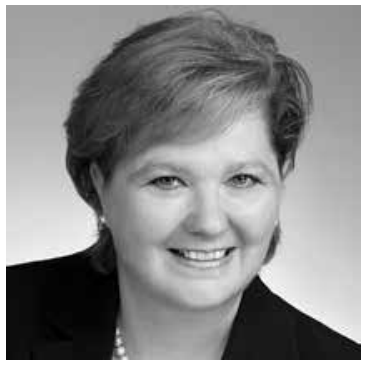

Birgitta Eder

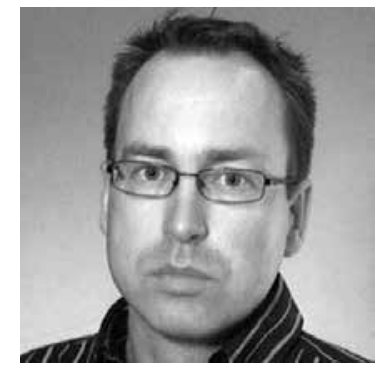

Mediterranean Economies Reinhard Jung

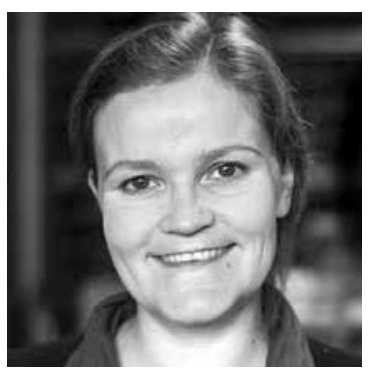

Prehistoric Identities Katharina Rebay-Salisbury

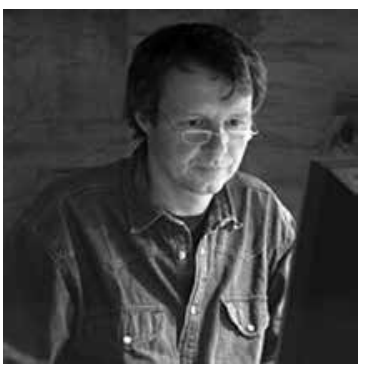

Quaternary Archaeology Thomas Einwögerer

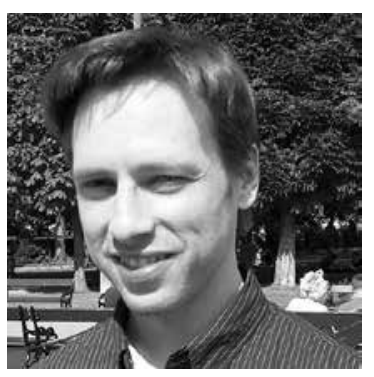

Levantine and Egyptian Histories Roman Gundacker

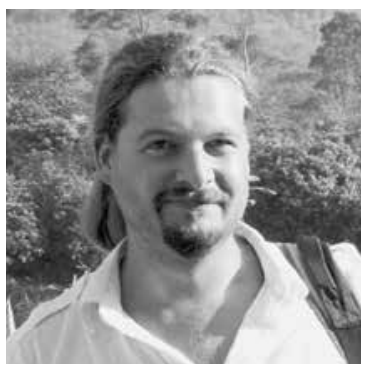

Raw Material Lab

Michael Brandl
Felix Höflmayer

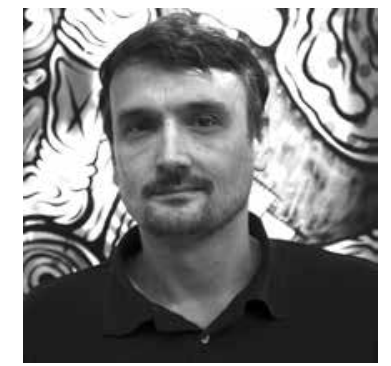

Urnfield Culture Networks (UCN) Mario Gavranović
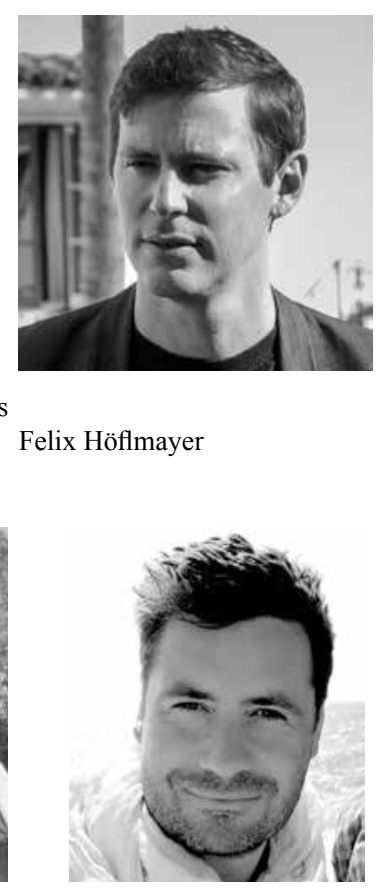

DIGital Documentation Lab Mario Börner

Fig. 6 OREA research group leaders and heads of labs 2019 (C OREA) 


\section{Research strategy}

The basis of the research program are the OREA research groups, built up since 2013, whose leaders are represented in an OREA panel of research group leaders (OREA Board). The research priorities defined in 2013 are now fully organised in groups, individual studies are the exception and mostly function as strategic pilot studies for potentially larger projects. The research groups are open to new input from incoming research fellows and additional adjacent projects and groups.

The strategy follows the focus defined in the OREA mission statement (see above) from research on the basis of humankind between the Orient and Europe to the transformation to historical societies of the $1^{\text {st }}$ millennium BC. In 2018 the following research groups existed: Quaternary Archaeology, Prehistoric Phenomena, Levantine and Egyptian Histories, Mediterranean Economies, Mycenaean Aegean, Material Culture in Egypt and Nubia, Tell el-Daba Publications, Urnfield Culture Networks and Prehistoric Identities were the formative impact on OREA's research.

\section{OREA Archaeology in Austria}

Many different OREA projects are located in Austria itself. Fieldwork (Lower Austria, Styria, Vienna) as well as extensive material analyses, large-scale and cross-regional studies in addition to the (re)assessment of older excavation materials/documentations concentrate on around 30 archaeological sites in Austria. Furthermore, OREA hosts long-term publication projects, supports and supervises academic theses dealing with Austrian issues and core themes, (co-)organises exhibitions at state- and national level whilst being actively engaged in national committees.

As the successive institution of the Prähistorische Kommission, which was already founded in 1878, OREA took over responsibility for all its archives and publishing obligations; moreover, several of OREA's projects examine its research history and the role of its former stakeholders.

All these studies and projects are embedded in the traditionally well-established cooperations with the federal authorities and their representatives as well as Austrian museums. Within the framework of the OREA research groups new state-of-the-art studies dealing with this wide range of topics are prepared, initiated, accomplished and published continuously. The journal Archaeologia Austriaca is jointly edited by the director of OREA together with the Institute for Prehistoric

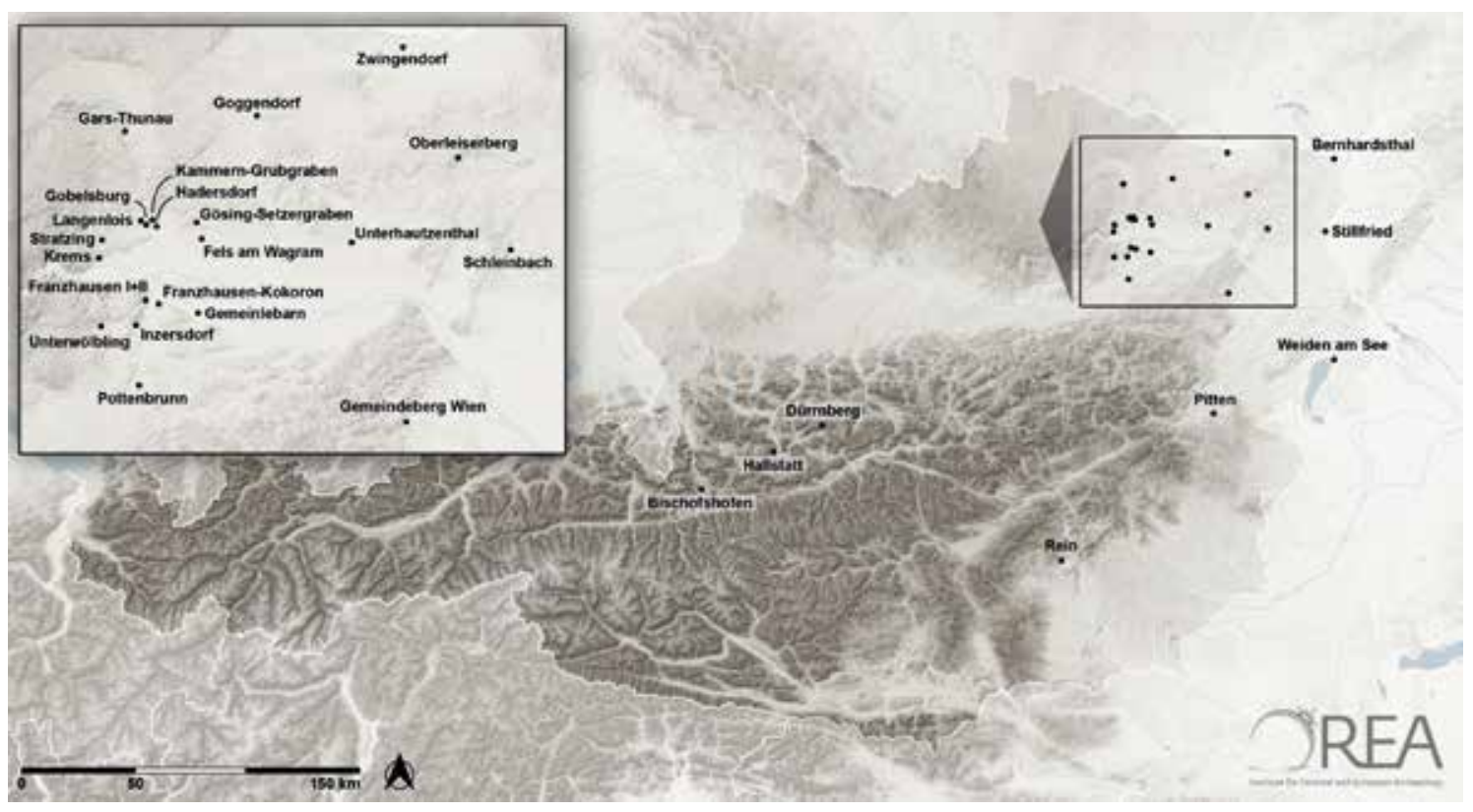

Fig. 7 OREA's archaeological activity areas in Austria (graphics: M. Börner/C OREA) 
and Historical Archaeology, University of Vienna, and is published by the the Austrian Academy of Sciences Press. This journal is an essential publishing body and represents an important internationally ranked journal for Austrian archaeology and published open access since 2018.

The tradition of prehistoric archaeology in Austria is reaching back far and has been documented by a project dealing with the "Die Prähistorische Kommission der kaiserlichen Akademie der Wissenschaften 1878-1918", carried out by Brigitta Mader, who presented her substantial publication on this topic on 18 December 2018. Still on-going is the preparation of the publication of the follow up project "Archäologie und Ideologie. Die Prähistorische Kommission der Österreichischen Akademie der Wissenschaften zwischen 1938 und 1948".

\section{Promotion of young researchers, career development, gender and diversity in 2018}

The already successful practice at OREA of promoting the development of young scientists has been continued. Young scientists are encouraged and supported to submit grants for their research projects and then carry out their research at an international level at OREA. The DOC scholarship holders at OREA are integrated into the research work of the OREA groups and supported by the group leaders. Gabriela Ruß-Popa was awarded a Herta Firnberg Post-Doc project SKIN: Ressourcen und Technologien in 2018. In 2018 the DOC Team The Role of Households at the Dawn of the Bronze Age - Contextualizing Social Organization of Maria Röcklinger, Constanze Moser, Stephanie Emra and Sabina Cveček continued with an international workshop at OREA. The research successfully continued with international placements for the members of the team in 2018 and continuation of the work at Ephesos. Aaron de Souza successfully secured a MSCA Scholarship for his research project INBETWEEN in 2018. The research fellows at OREA are encouraged to build their own new projects and international networks based on their respective projects and the resulting collaborations. Benedikt Biederer was awarded a DOC scholarship in 2018 for his work on "Herausforderung Vorratshaltung. Essentielle Strategien im urgeschichtlichen Europa vom Neolithikum bis in die Eisenzeit".

OREA especially supported workshops and conferences for young scientists as their workshops and conferences were integrated into larger scale conferences or organised independently and will take place continuously, actively supported by OREA, to give young researchers the possibility to present and publish their preliminary through to their further results.

OREA, especially its director, is actively involved in the "Initiative for the promotion of women in science" as well as in the mentoring programme of the Austrian Academy.

Cooperation in the field of teaching exists in Austria, especially with the Institute of Prehistoric and Historical Archaeology and the Institute for Egyptology, the Institute for Old History, "Altertumskunde" Papyrology and Epigraphics, the Institute for Classical Archaeology as well as the Faculty of Protestant Theology, all at the University of Vienna, supported by an updated co-operation agreement on archaeological research and teaching with the University of Vienna in 2018. Internationally, teaching co-operations with the Universities of Tübingen, Heidelberg, Leuven, New Bulgarian University (Sofia), Tel Aviv and Istanbul exist.

\section{Publication strategy}

The institute's strategy covers two different fields of publication: OREA's own publication series and journals as well as external international publications by OREA scientists in high ranked journals.

OREA Publications of the Institute for Oriental and European Archaeology

CAENL Contributions to the Archaeology of Egypt, Nubia and the Levant (series closed in 2018)

UZK Untersuchungen der Zweigstelle Kairo des Österreichischen Archäologischen Instituts (Analyses of the Cairo branch of the Austrian Archaeological Institute) 
MPK

Mitteilungen der ehem. Prähistorischen Kommission (Communications of the Prehistoric Commission)

MykStud Mykenische Studien (Mycenaean Studies)

Ägypten und Levante / Internationale Zeitschrift für ägyptische Archäologie und deren Nachbargebiete / Egypt and the Levant International Journal of Egyptian Archaeology and Related Disciplines Archaeologia Austriaca Zeitschrift zur Archäologie Europas / Journal on the Archaeology of Europe

All series and journals edited and published by OREA are internationally peer-reviewed and follow the high state-of-the-art standards of scientific publications, regularly monitored by the Austrian Academy of Sciences and its publishing house as well as by international ranking institutions (ESCI, ERIH).

In 2018 the following books have been published by OREA:

- Brigitta Mader, Die Prähistorische Kommission der kaiserlichen Akademie der Wissenschaften 1878 1918, MPK 86 (Vienna 2018).

- Elisabeth Nowotny, Thunau am Kamp-Das frühmittelalterliche Gräberfeld auf der Oberen Holzwiese. Mit Beiträgen von Karina Grömer, Martin Ježek, Mathias Mehofer, Erich Nau, Gabriela Ruß-Popa und Sirin Uzunoglu-Obenaus, MPK 87 (Vienna 2018).

- Christoph Schwall, Çukuriçi Höyük 2. Das 5. und 4. Jahrtausend v. Chr. in Westanatolien und der Ostägäis. Mit einem Beitrag von Barbara Horejs, OREA 7 (Vienna 2018).

- William Anderson - Kristen Hopper - Abby Robinson (eds.), Landscape Archaeology in Southern Caucasia. Finding Common Ground in Diverse Environments. Proceedings of the Workshop held at $10^{\text {th }}$ ICAANE in Vienna, April 2016, OREA 8 (Vienna 2018).
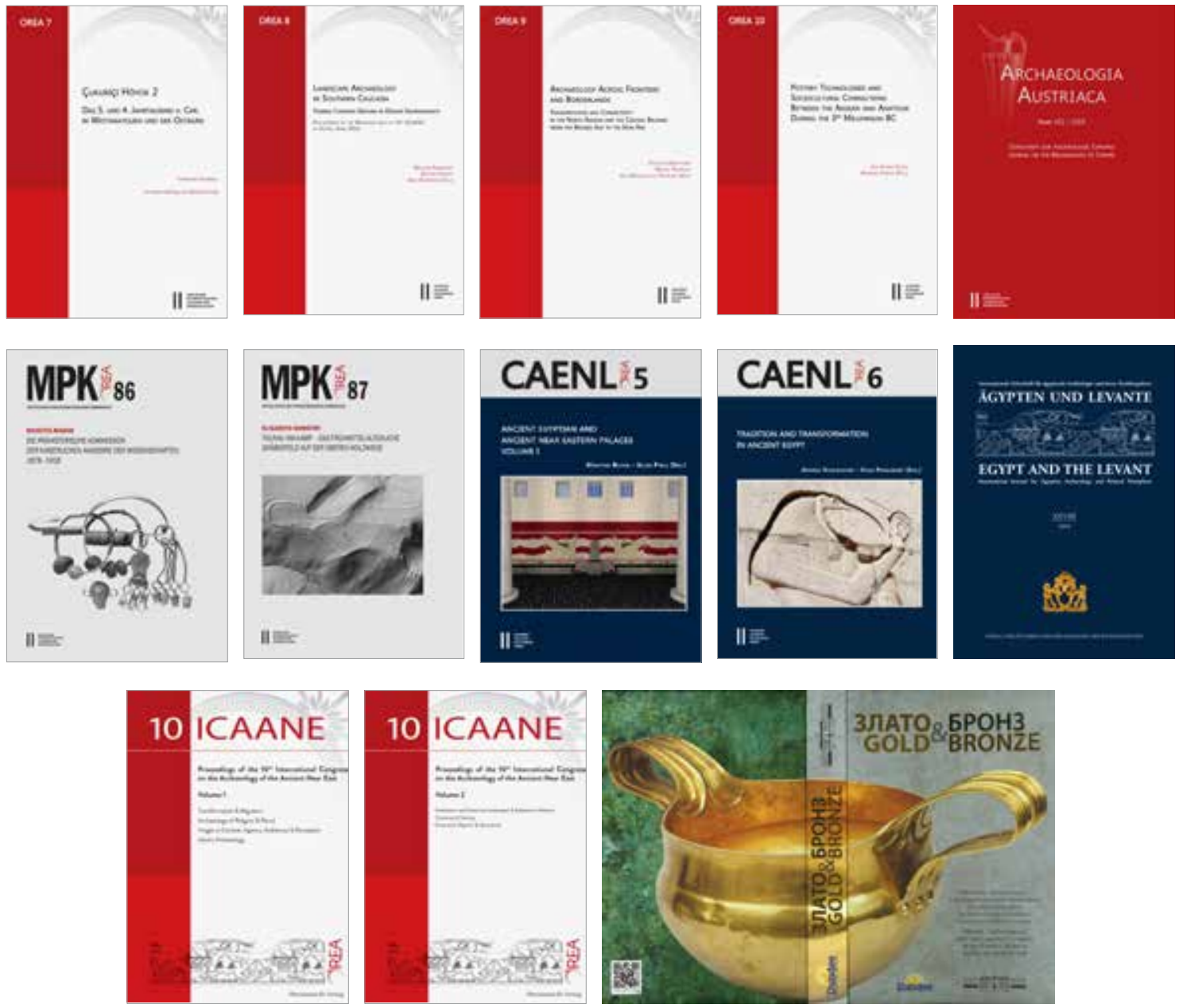

Fig. 8 OREA's Publications 2018 
- Stefanos Gimatzidis - Magda Pieniążek - Sila Mangaloğlu-Votruba (eds.), Archaeology Across Frontiers and Borderlands. Fragmentation and Connectivity in the North Aegean and the Central Balkans from the Bronze Age to the Iron Age, OREA 9 (Vienna 2018).

- Eva Alram-Stern - Barbara Horejs (eds.), Pottery Technologies and Sociocultural Connections Between the Aegean and Anatolia During the $3^{\text {rd }}$ Millennium BC, OREA 10 (Vienna 2018).

- Barbara Horejs - Christoph Schwall - Vera Müller - Marta Luciani - Markus Ritter - Mattia Giudetti - Roderick B. Salisbury - Felix Höflmayer - Teresa Bürge (eds.), Proceedings of the $10^{\text {th }}$ International Congress on the Archaeology of the Ancient Near East, 2 volumes (Wiesbaden 2018).

- Stefan Alexandrov - Yana Dimitrova - Hristo Popov - Barbara Horejs - Krastyu Chukalev (eds.), Злато \& бронз / Gold \& Bronze. Metals, Technologies and Interregional Contacts in the Eastern Balkans during the Bronze Age (Sofia 2018).

- Manfred Bietak - Silvia Prell (eds.), Ancient Egyptian and Ancient Near Eastern Palaces. Volume I, CAENL 5 (Vienna 2018).

- Andrea Kahlbacher - Elisa Priglinger (eds.), Tradition and Transformation in Ancient Egypt. Proceedings of the Fifth International Congress for Young Egyptologists, 15-19 September, 2015, Vienna, CAENL 6 (Vienna 2018).

- Archaeologia Austriaca 102/2018.

- Ägypten und Levante 28/2018.

\section{Global Eurasia - initiatives and perspectives}

The research institutes devoted to the humanities and located in the AAS offices in Hollandstraße, Vienna, developed a common focus on "Global Eurasia". The goal was to create an enhanced interconnectedness between these very successful research bodies, as well as to initiate new research perspectives and trigger new approaches. 7 institutes are part of the interdisciplinary research initiative:

- Institute for the Study of Ancient Culture - IKAnt

- Institute for Oriental and European Archaeology - OREA

- Institute of Iranian Studies - IFI

- Institute for the Cultural and Intellectual History of Asia - IKGA

- Institute for Social Anthropology - ISA

- Institute for Medieval Research - IMAFO

- Institute for Modern and Contemporary Historical Research - INZ

Global Eurasia was inaugurated on 7 June 2017 by the participating institutes with a kick-off meeting and presentations on their subject focus and their visions for the initiative. A first success for the initiative is the foundation of a new official AAS Platform Global Eurasia in 2018, going public with events, workshops and lectures in the near future. A Strategic Focus Programme has been developed for 2019-2020 which will start in Spring 2019.

\section{International perspectives and co-operations in 2018}

OREA and its scientists pursue internationally orientated projects and actively participate in international initiatives e.g. Horizon 2020 applications, especially in the category excellent science. In collaboration with our colleagues from the Danube region and the Balkans, OREA collaborated in strategies concerning these areas, as well as in the AAS (JESH programme), and continued its participation in the HERA initiative. OREA (E. Aspöck) successfully received funding for participation in ARIADNE+ and COST. As a result of the synergies involved, both projects will be implemented at the Austrian Centre for Digital Humanities of the Austrian Academy of Sciences.

OREA was also able to establish itself as the Centre for Balkan Archaeology with the FWF-funded project Gold Roads of the Balkans. The Innovation Fund projects Golden Trea- 
sures and Visualizing the unknown Balkans continued. Several field projects and co-operations in Bosnia, Croatia, North Macedonia, Bulgaria and Serbia complement the Balkan Archaeology forum. Daria Ložnjak Dizdar (Institute of Archaeology, Zagreb) was awarded a JESH scholarship for her research on "Landscape and communication network in the Late Urnfield Culture in the Sava valley". Several new co-operation agreements were established, among them those with the National Museum in Belgrade or the Archaeological Museum Macedonia.

Further activities concerning Iran and the United Arab Emirates have been continued in 2018 and will be continuously developed in 2019 .

In Lebanon, the investigations by Karin Kopetzky within the framework of the FWF project continued with the research focus Between Land and Sea - The Chekka Region in Lebanon in co-operation with Hermann Genz of the American University of Beirut.

Michaela Zavadil and Laura Burkhardt were awarded Athens scholarships for a two-month scientific stay in Athens for comparative studies to complement their research. Reinhard Jung is in close cooperation with the University of Zurich and holding lectures on a regular basis at the Institute for Archaeology, Department of Prehistoric Archaeology.

\section{Guest Scientists in 2018}

- Uroš Matić (University of Münster) spent February 2018 to January 2019 at OREA as a mobility visit during his post-doc project "Beautiful Kush: Cosmetic substances and utensils in New Kingdom Nubia" as part of the DAAD P.R.I.M.E programme. He collaborated closely with Bettina Bader's research group Material Culture in Egypt and Nubia, in terms of theoretical approaches, as well as on object-specific questions.

- Annalisa Rumolo (funded by the Gerda-Henkel-Stiftung) is co-operating with the Mediterranean Economies Group and currently writing her $\mathrm{PhD}$ thesis at OREA with the main focus on the reconstruction of diet and mobility of targeted individuals at the cemetery of Portes in Achaea (north-western Peloponnese) and a general reassessment of published isotopic and archaeological evidence from coeval Mycenaean sites.

- Julie Dunne (University of Bristol) and Alexander Frisch (Museum Regensburg) visited OREA from 14 to 16.5.2018 to sample Bronze and Iron Age feeding vessels at the Natural History Museum in Vienna.

- Ken Massy (Ludwig-Maximilian University, Munich) visited OREA on 17.7.2018 to compare early Bronze Age cemeteries in Bavaria and Lower Austria.

- Christophe Snoeck (Vrije Universiteit Brussel) visited OREA from 22 to 23.10.2018 to foster collaboration on reconstructing migration paths at late Bronze Age cemeteries in the Traisen valley through strontium isotope analysis.

- Veronica Tamorri (London/Durham, UK, Rome, Italy) visited OREA in advance of submitting her Marie Skłodowska-Curie Individual Fellowship on 12.9.2018. Her stay was supported by the OeAW Grant Service under the Compensation for H2020 application costs scheme.

- During the last week of November, Alba Masclans Latorre (University of Barcelona) conducted use wear analyses on ground stone tools from the early Neolithic burial site of Kleinhadersdorf in Lower Austria. First results indicate that the stone axes examined were used for a wide array of tasks aside from woodworking.

- Yana Dimitrova (Institute of Archaeology and Museum, Bulgarian Academy of Sciences) and Petar Minkov (Sofia University "St. Kliment Ohridski”) are cooperating in the Ada Tepe project within the Mediterranean Economies. From 1.11. to 15.12.2018 they conducted comparative studies of the material culture of the Metal Ages at OREA. 
Turkey Scientific Initiative of the Austrian Academy of Sciences at OREA

In the framework of the Turkey Scientific Initiative of the Austrian Academy of Sciences, initiated by Barbara Horejs and generously supported and funded by the Presiding Committee, in 2018 OREA hosted seven Turkish scientists for several months each to intensify the co-operation with Turkish scholars and to foster bilateral archaeological research under difficult political conditions.

The guests of the initiative cover a wide range of research interests, thus initiating a mutually fruitful scientific discourse. The visiting researchers were:

\begin{tabular}{|l|l|l|}
\hline $\begin{array}{l}\text { Prof. Dr. Ciler Çilingiroğlu } \\
\text { (Ege University, Izmir) }\end{array}$ & 03.01.-28.02.2018 & $\begin{array}{l}\text { Pre-neolithic horizons in der Aegean and Western Anatolia, } \\
\text { first contact of hunter-gatherers }\end{array}$ \\
\hline $\begin{array}{l}\text { Dr. Sinan Ünlüsöy } \\
\text { (Yaşar University, Izmir) }\end{array}$ & $03.01 .-28.02 .2018$ & The breakdown of societies in Anatolia around 2200 BC \\
\hline $\begin{array}{l}\text { Dr. Neyir Kolankaya-Bostancı } \\
\text { (Hacettepe University, Ankara) }\end{array}$ & $22.01 .-05.02 .2018$ & $\begin{array}{l}\text { Exchange/trade network in western Anatolia during Late Neo- } \\
\text { lithic, Chalcolithic and Early Bronze Age of obsidian artefacts }\end{array}$ \\
\hline $\begin{array}{l}\text { Prof. Dr. Metin Kartal } \\
\text { (Ankara University, Ankara) }\end{array}$ & $01.02 .-14.02 .2018$ & $\begin{array}{l}\text { Research on Paleolithic, Neolithic and Chalcolithic chipped } \\
\text { stone techno-typology in Turkey }\end{array}$ \\
\hline $\begin{array}{l}\text { Dr. Gizem Kartal } \\
\text { (Ankara University, Ankara) }\end{array}$ & $01.02 .-14.02 .2018$ & Chipped stone technology and pressure technique \\
\hline $\begin{array}{l}\text { Dr. Yavuz Aydın } \\
\text { (Ankara University, Ankara) }\end{array}$ & $01.09 .-16.12 .2018$ & $\begin{array}{l}\text { Techno-typology of the Lower Paleolithic chipped stone tool } \\
\text { assemblage from Karain Cave, Antalya }\end{array}$ \\
\hline $\begin{array}{l}\text { Dr. Buket Aydın } \\
\text { (Ankara University, Ankara) }\end{array}$ & $01.09 .-16.12 .2018$ & $\begin{array}{l}\text { Techno-typology of the Lower Paleolithic chipped stone tool } \\
\text { assemblage from Karain Cave, Antalya }\end{array}$ \\
\hline
\end{tabular}

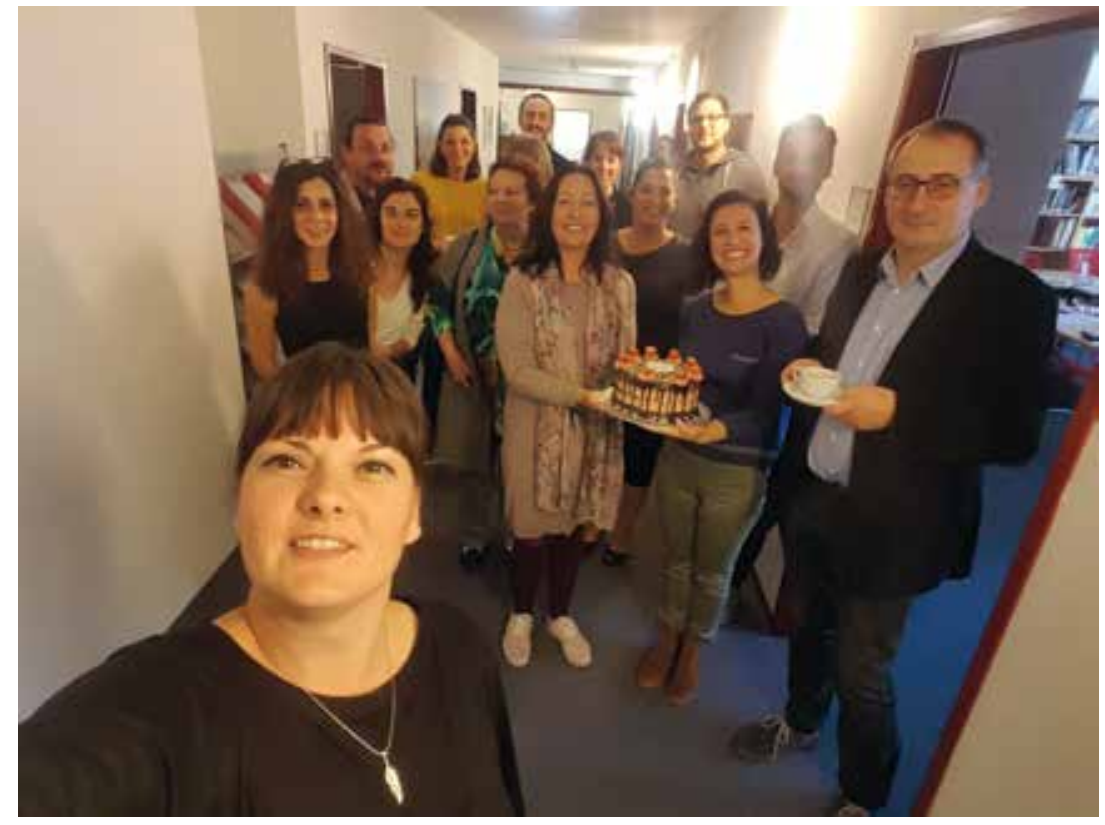

Fig. 9 Ciler Çilingiroğlu celebrating her birthday at OREA with the team Prehistoric Phenomena and guests (photo: B. Milić) 


\section{High Impact National and International Outreach in 2018}

\section{Gold and Bronze. Metals, Technologies and Networks in the Eastern Balkans during the Bronze Age, National Archaeological Museum in Sofia}

From 25 October 2017 until 28 January 2018, the exhibition "Gold and Bronze. Metals, Technologies and Networks in the Eastern Balkans during the Bronze Age" was shown in the National Archaeological Museum in Sofia. It was a joint project by the National Archaeological Museum, the Institute of Oriental and European Archaeology/Austrian Academy of Sciences (OREA) and the Kunsthistorisches Museum Wien which was dedicated to the so-called Golden Path in the Balkans during the Bronze Age. As part of the same project, the exhibition "The First Gold: Ada Tepe the Oldest Gold Mine in Europe" (7.3.- 25.6.2017) was shown at the Kunsthistorisches Museum in Vienna in 2017 (see Annual Report 2017, 53-54) and ranked the most successful exhibition in the category Antiquities in The Art Newspaper on 26 March 2018, with 231,553 visitors. The difference between the two exhibitions was that in Sofia a lot more exhibits could be presented - more than 600 objects from the abundance of collections of 29 archaeological museums in Bulgaria were presented. The exhibition "Gold and Bronze, Metals, Technologies and Networks in the Eastern Balkans during the Bronze Age" was part of the cultural programme of the Bulgarian and Austrian EU Council Presidency in 2018 (Fig. 10). The exhibition in Sofia was also accompanied by a catalogue, published in 2018 with contributions by OREA from Barbara Horejs and Reinhard Jung, as well as the OREA cooperation partners Ernst Pernicka, Peter Pavúk and Mathias Mehofer.

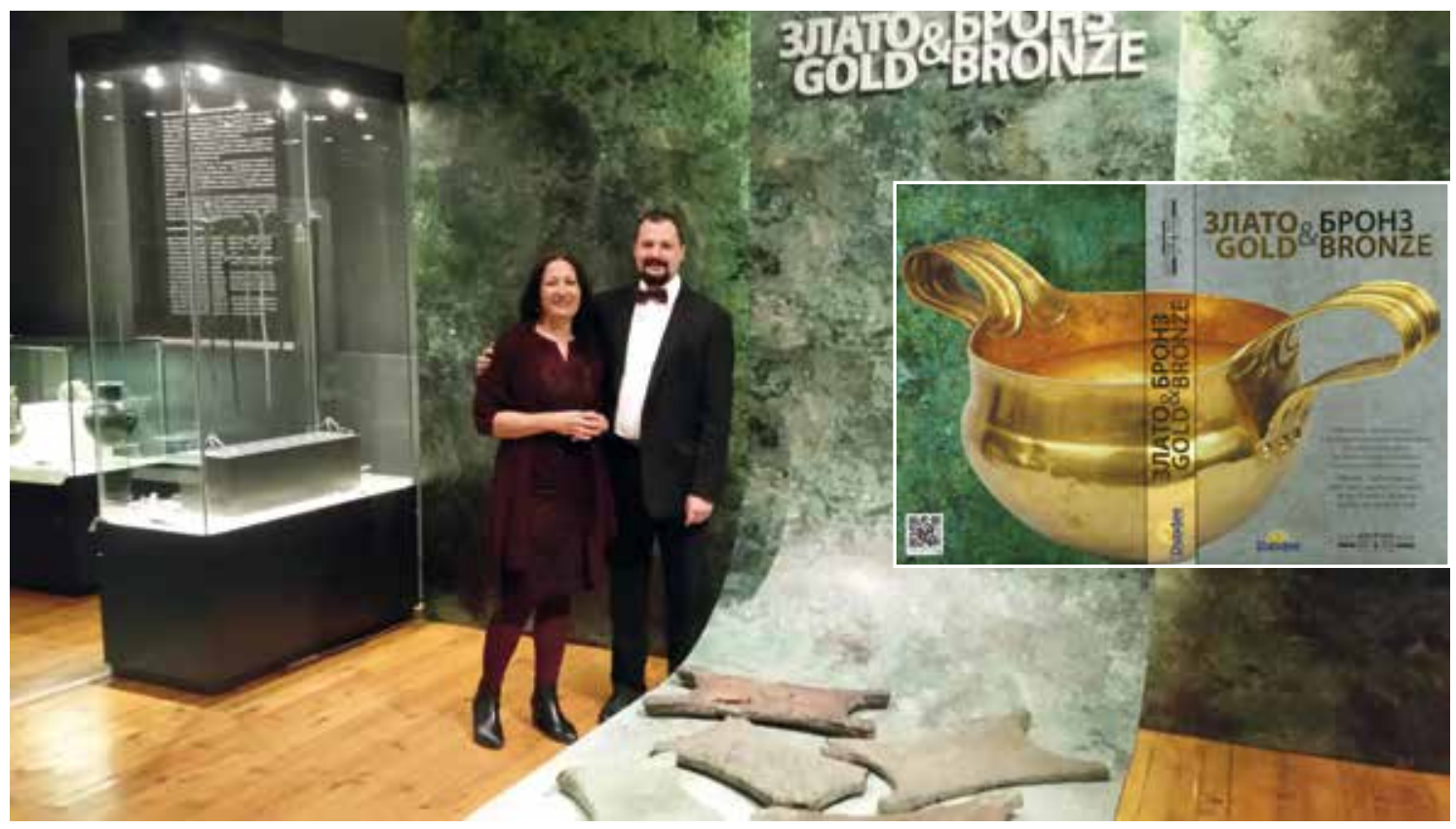

Fig. 10 Barbara Horejs and Hristo Popov (Bulgarian Academy of Sciences) at the opening of the exhibition "Gold \& Bronze" in Sofia (photo: D. Melman, C OREA) and the cover of the accompanying book, partly coauthored by OREA scientists

Die Lange Nacht der Forschung (LNF)

OREA at the largest Research Event in Austria (13 April 2018)

The LNF event is the only nationwide event of science-communication in Austria, the public outreach to 228,000 visitors proving a success for the $8^{\text {th }}$ edition of the event. The Austrian Academy 


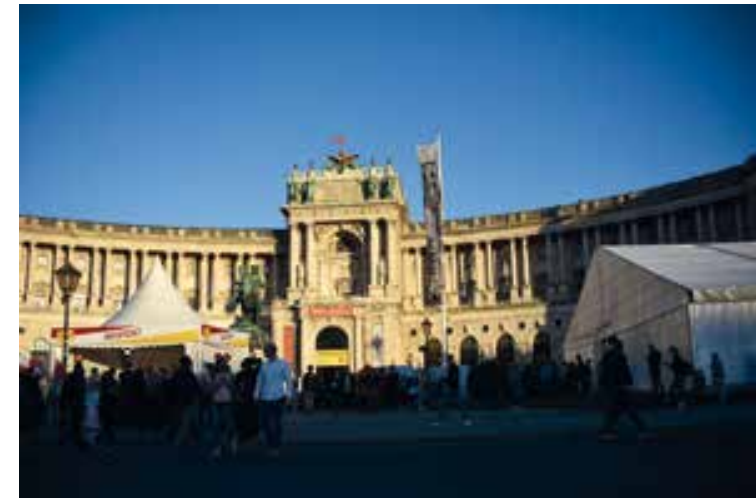

Fig. 11 LNF 2018 at the Heldenplatz, Vienna (photo: F. Ostmann, (C) OREA)

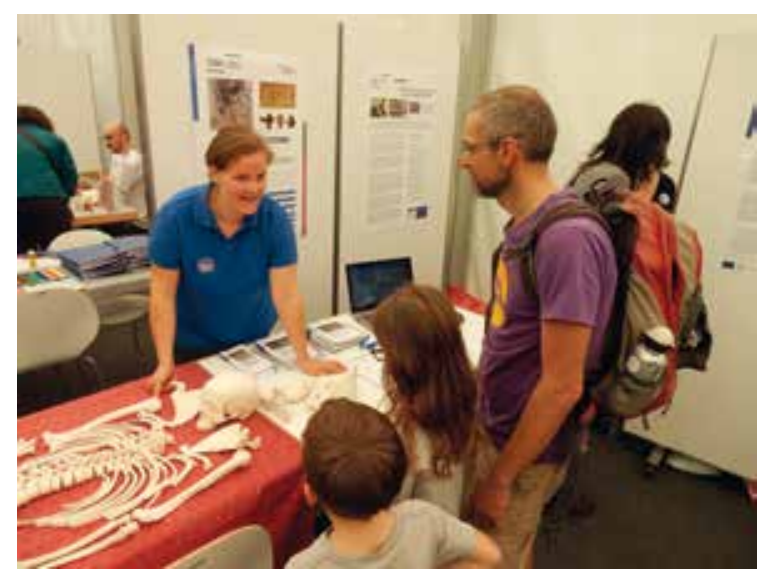

Fig. 13 LNF 2018, K. Rebay-Salisbury, presenting hands on The Value of Mothers to Society (photo: M. Fritzl, C OREA)

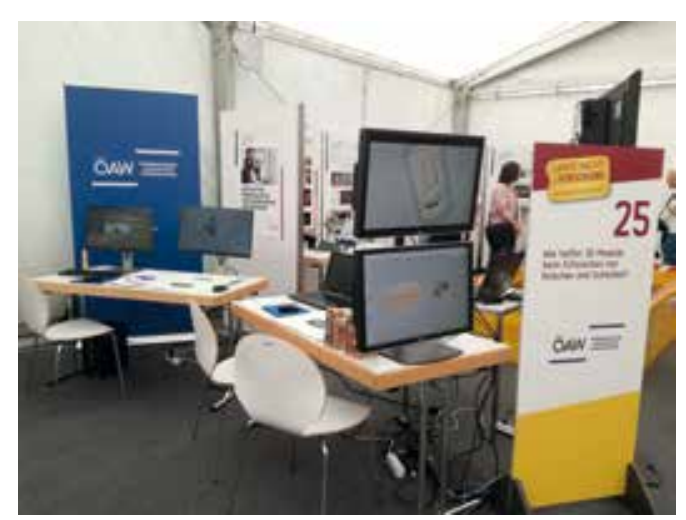

Fig. 12 Presenting digital documentation methods at the LNF (photo: F. Ostmann, (C) OREA)

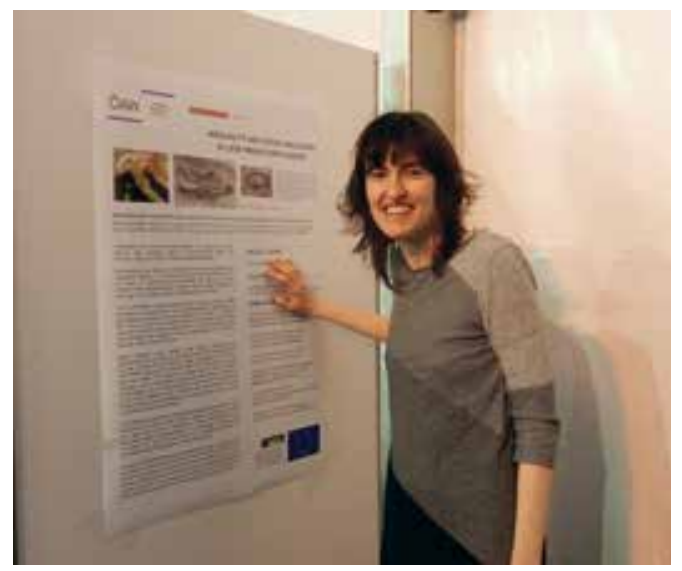

Fig. 14 Elisa Perego presenting her project at the LNF 2018 (photo: K. Rebay-Salisbury, (C) OREA)

of Sciences participated under the title of "Lebendiges Altertum" / "Antiquity coming to life" in a pavilion on the Heldenplatz, Vienna (https://www.oeaw.ac.at/lnf2018/) (Fig. 11). OREA once more participated in 2018 and contributed with presentations of the latest innovations and methods of data visualisation and 3D visualisations of archaeological records (Fig. 12). Reconstructions and 3D-modelling in particular lead to a better understanding of archaeologists' results and allow us to communicate these to the broader public. Virtual walk-throughs of ancient Egyptian tombs and palaces were accessible for the interested visitors and virtual models of prehistoric skeletons could be compared with anatomic models as a real experience on the spot. The lively response from the visitors, the range spanning from schoolchildren to third agers, again showed the wide fascination with the legacy of ancient times. OREA's contributions were organised by the Digital Archaeology team, the Prehistoric Identities group (Figs. 13, 14) and the ERC Hyksos Enigma team.

\section{'Beyond Death: Exploring the uses of dead bodies, funerary objects, and burial spaces through time' (2-4 May, 2018)}

The international conference 'Beyond Death: Exploring the uses of dead bodies, funerary objects, and burial spaces through time' was organised by Estella Weiss-Krejci and Sebastian Becker and held at the Austrian Academy of Sciences, Hollandstraße, from 2-4 May 2018, with nineteen speakers from the UK, Germany, the Netherlands, Czech Republic, France, Sweden, and Austria (e.g. Harald Meller, Mike Parker Pearson, Paul Pettitt, Antonius Robben, Philip Schwyzer, Julia Smith, etc.) (Fig. 15). The conference explored the uses and meanings of dead 
bodies, objects, and burial spaces over long periods of time and raised the following questions: How is it that the dead become flashpoints of controversy, interest, and identity for the living? How have interactions with dead bodies and related artefacts been used in different time periods and cultures to underwrite, rewrite, or overturn narratives of national or community origin? How and why do material remains come to embody the past in the present, collapsing essential distinctions in temporality? As this topic is most fruitfully approached from a wide range of perspectives, contributions were invited from the fields of archaeology, literary studies, social and physical anthropology, and history. The inaugural lecture Hominin Evolutionary Thanatology. The LongTerm Evolution of Mortuary Activity from Face-to-Face to Place was held by Paul Pettitt, UK. Find the detailed Programme under https://www.orea.oeaw.ac.at/filead$\mathrm{min} /$ Institute/OREA/Events/2018/BeyondDeath/BeyondDeath_Program.pdf.

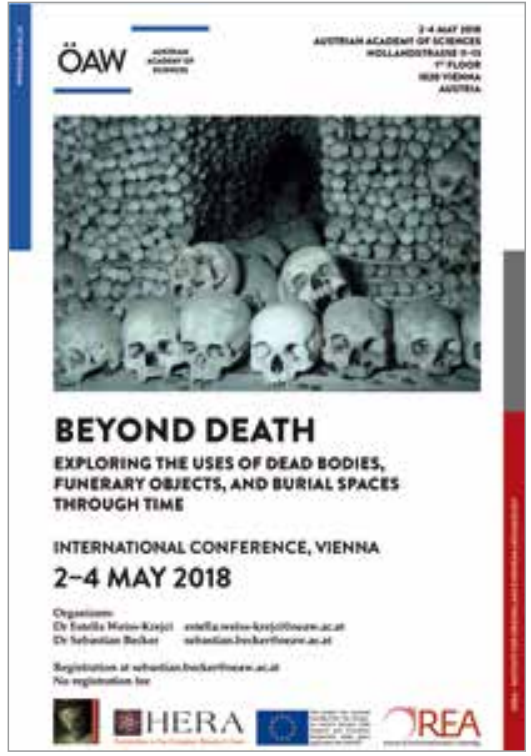

Fig. 15 Conference Beyond Death

\section{OREA at BE OPEN - Science \& Society Festival: 50 years of top-level research in Austria}

An event organized by the FWF - the Austrian Science Fund - under the auspices of the President of the Republic of Austria, Alexander Van der Bellen, within the framework of the Austrian EU Presidency (8-12 September 2018), celebrating the 50 ${ }^{\text {th }}$ anniversary of the Austrian Science Fund.

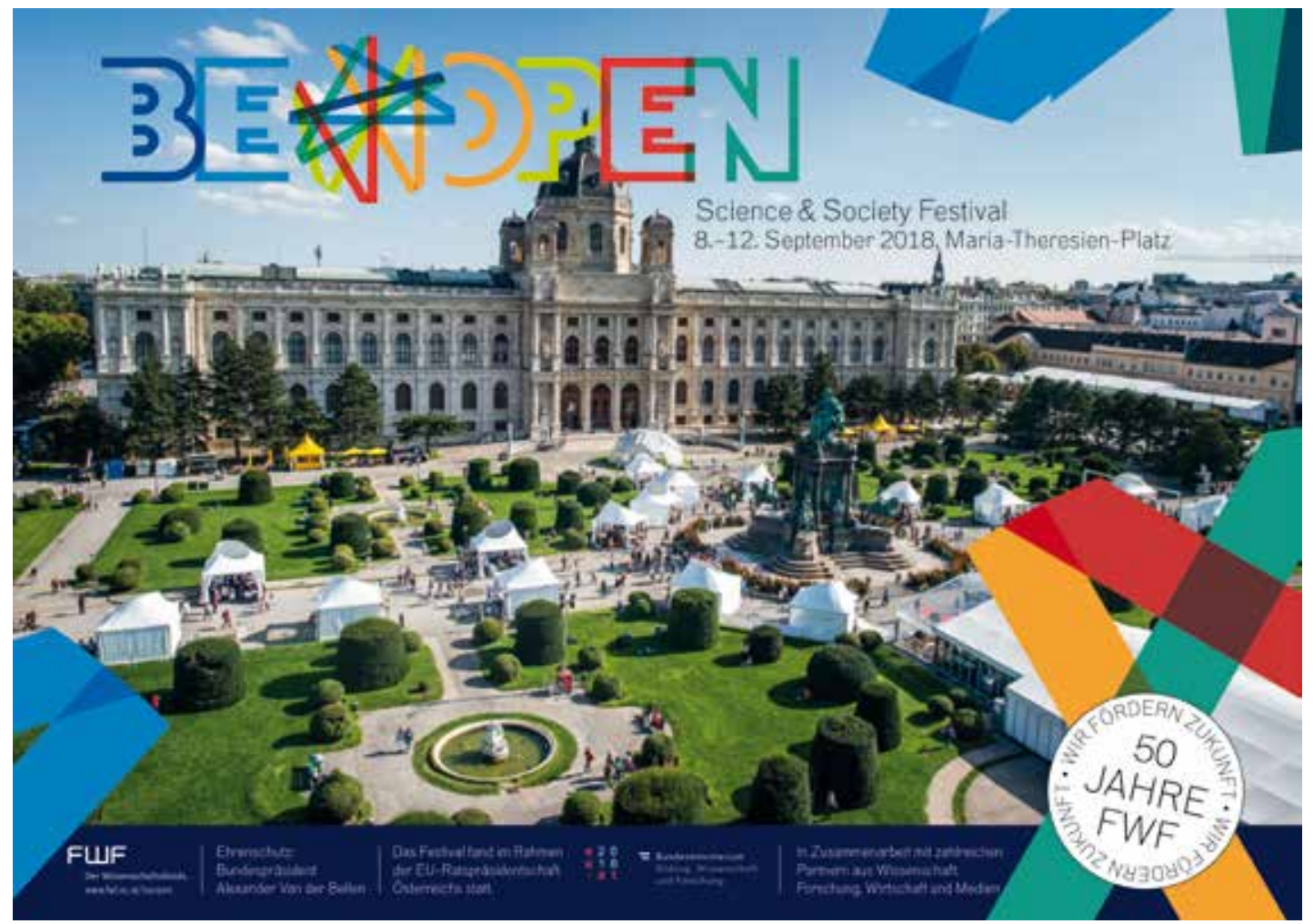

Fig. 16 BE OPEN 2018 (grafics after FWF Nachlese www.fwf.ac.at/fileadmin/files/Dokumente/Ueber_den_FWF/ BE_OPEN/BE_OPEN_Nachlese_d.pdf) 


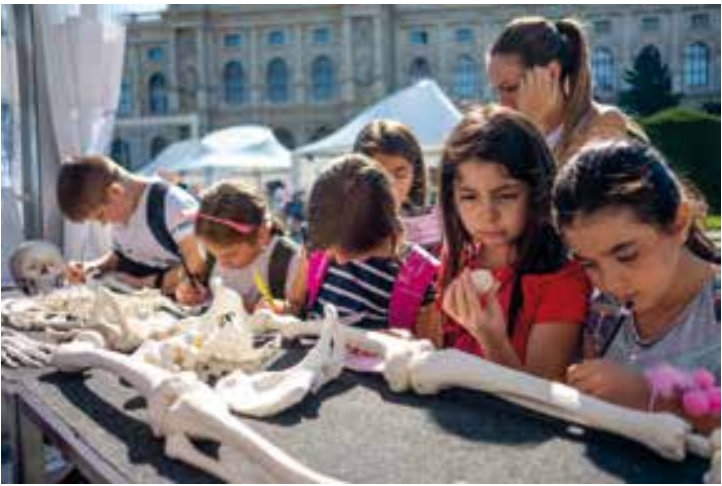

Fig. 17 School children inspired by archaeology of the body (photo: K. Rebay-Salisbury, (C) OREA)

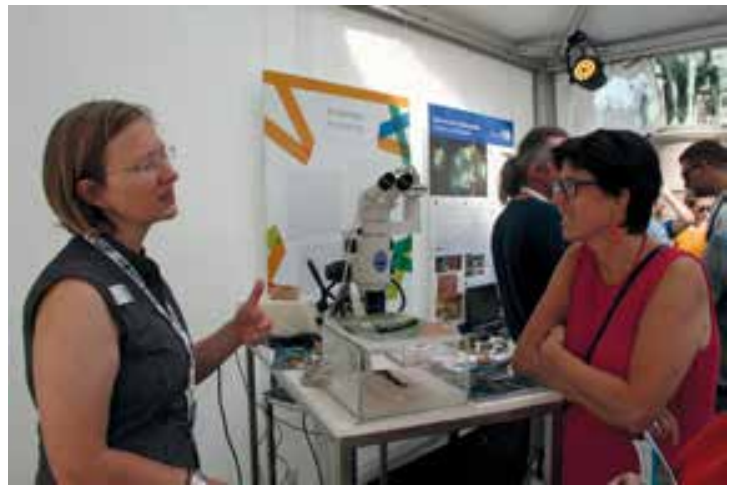

Fig. 18 K. Kowarik, NHM, Vienna at BE OPEN (photo: S. Pratsch, (C) OREA)

The Austrian Science Fund (FWF) celebrated its $50^{\text {th }}$ anniversary together with partners from the sciences, the economy, media and society, organizing the festival BE OPEN. The festival invited the public to get in touch with basic research, enter into a dialogue and meet the scientists in person (Fig. 16).

A selection of the best Austrian scientists and their teams were invited to permit the public a glance into their pioneering work. Future issues concerning the economy and society were discussed in a dialogue forum. Programmes for children, families, students and the broader public invited them to immerse themselves in scientific topics.

More than 30,000 visitors engaged in dialogue with 150 participating scientists in 18 science pavilions at the event venue, the Maria Theresien Platz in Vienna.

Barbara Horejs, representing the Austrian Academy of Sciences, was nominated as curator of the archaeology pavilion for the Austrian scientific community in Archaeology and organized the pafilion together with Sigrid Pratsch. The key question Was bringen 40.000 Jahre Migration? What do 40,000 Years of Migration Imply? set the focus on the transformations, innovations and developments triggered by human migration, the sustainable changes still influencing our modern world and traceable in archaeological research.

OREA and its partners (see below) presented their research portfolio with focused questions on migration during the last 40 millennia. Key areas were:

- Jäger und Sammler im Donauraum, Thomas Einwögerer, Michael Brandl and teams

- Wege der ersten Ackerbauern nach Europa, Barbara Horejs and team

- Die Archäologie des Körpers, Katharina Rebay-Salisbury and team (Fig. 17)

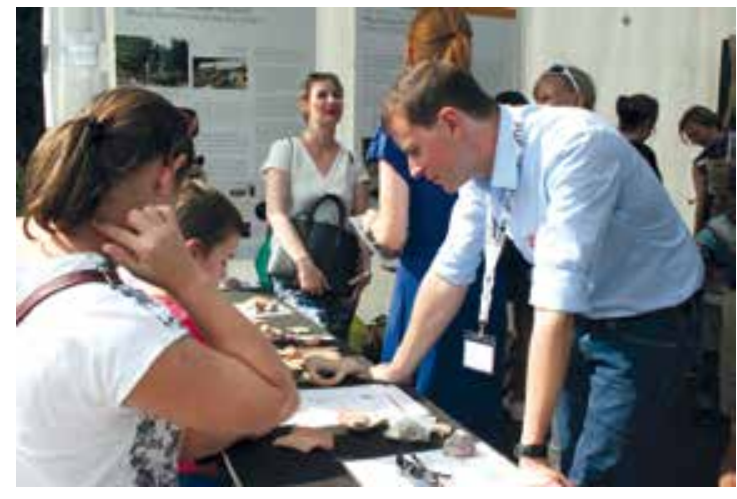

Fig. 19 Explaining documentation methods, F. Höflmayer (photo: S. Pratsch, C OREA)

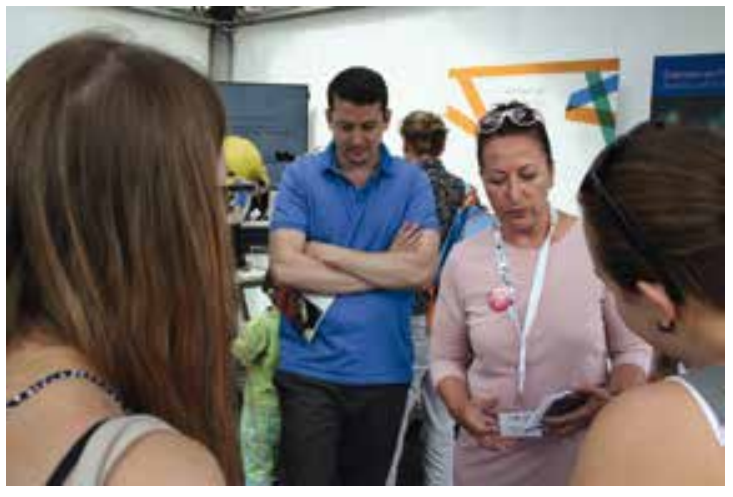

Fig. 20 Graduate students invited by B. Horejs to participate in the quiz (photo: S. Pratsch, (C) OREA) 


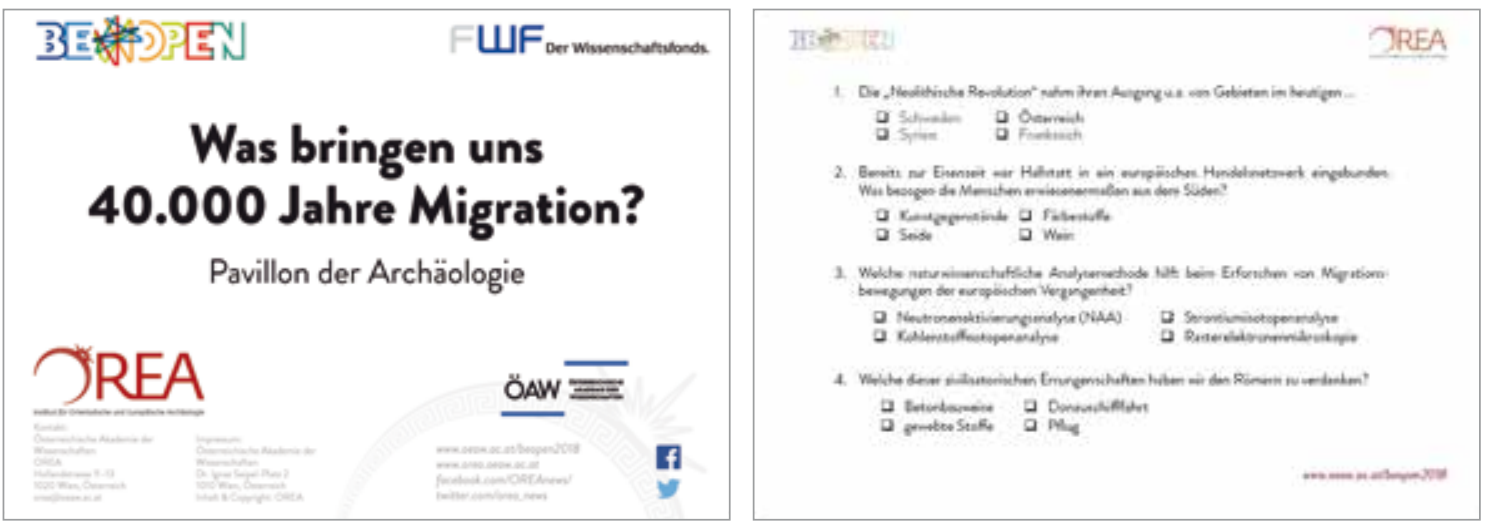

Fig. 21 Multiple choice test for adults (C OREA)

- Mobilität \& Handel im östlichen Mittelmeer, Felix Höflmayer, Katharina Streit (Hebrew University of Jerusalem), Johannes Sterba (Institute of Atomic and Subatomic Physics, Technical University of Vienna) (Fig. 19)

- Salzbergwerk Hallstatt, Kerstin Kowarik, Hans Reschreiter, Fiona Poppenwimmer, Daniel Brandner (NHM Vienna) (Fig. 18)

- Carnuntum - Metropole im Grenzgebiet, Gabrielle Kremer (IKant, Institute for the Study of Ancient Culture)

Awareness of the contents was intensified by the opportunity to answer questions related to the key topics of the exhibition, displayed on handout cards. Two versions - one for children and a multiple choice test for adults - were available. (Figs. 20, 21).

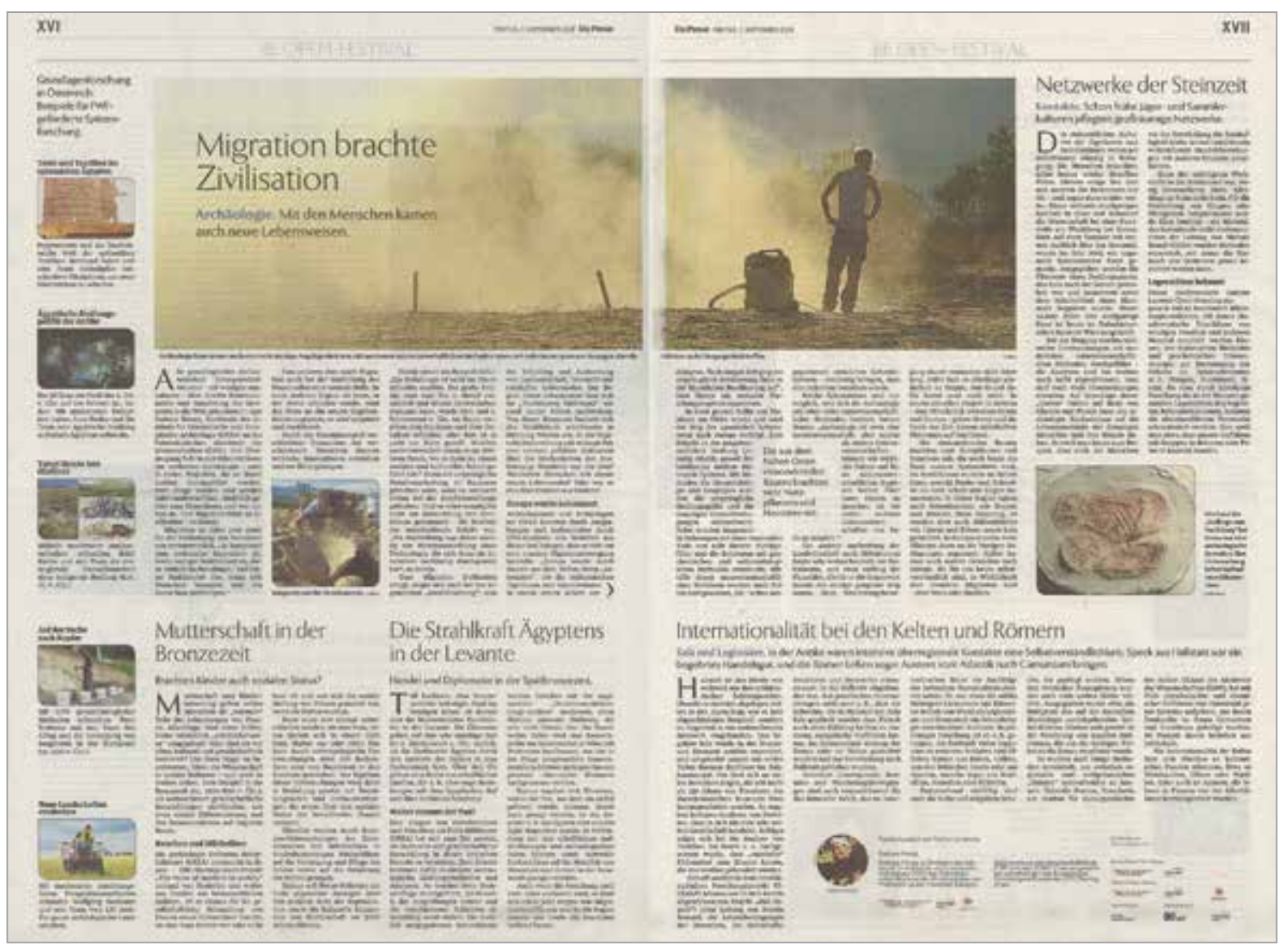

Fig. 22 BE OPEN Festival Paper by Die Presse, presenting the "Archaeology pavilion" (C Die Presse) 
The newspaper Die Presse issued a special Festival Paper, covering the archaeological research on two whole pages (Fig. 22).

The festival can be called a real success, with OREA participating in the centre of the pavilion village and thus reaching a considerable number of interested visitors (see also Facts \& Figures).

\section{Facts \& Figures: ${ }^{*}$}

$\checkmark 18$ science pavilions, 150 scientists, more than 30,000 visitors - including 2,000 students with their teachers

$\checkmark 30$ partner organisations from science and the economy

$\checkmark 500,000$ media outreach in partner communities

$\checkmark 4$ ORF TV and radio broadcasts

$\checkmark 250$ media \& social-media contributions

$\checkmark 750,000$ spectators

\section{Tag des Denkmals}

Monuments Day 2018, 30 September

Within the public outreach event of the Federal Monuments Office, OREA presented the topic "Visualizing the unknown Balkans" - Bronze Age metallurgy and Neolithic expansion in the Balkans, with the presentation being hosted in the main building of the Austrian Academy of Sciences. A movie introduced the topic to the interested audience and visitors were able to obtain "hands-on experience" with raw materials, metallurgical tools, analytic approaches to Bronze Age metallurgy and traces of early farming Neolithic cultures (crops, plants) in the Balkans. Irene Petschko and Mario Gavranović provided the visitors with inside information on the archaeological research and specific tasks in the project. The OREA station and the project "Visualizing the unknown Balkans" attracted a large portion of the audience of around 600 visitors (Fig. 23).

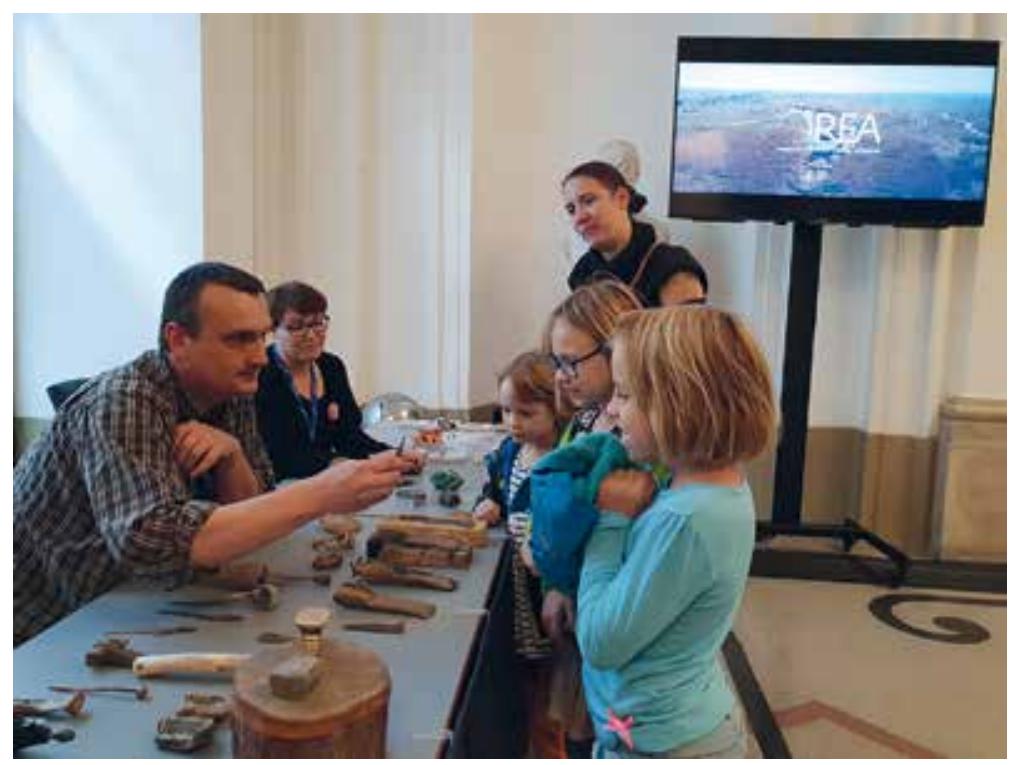

Fig. 23 Monuments Day, OREA presenting Visualizing the unknown Balkans, I. Petschko and M. Gavranović (photo: F. Ostmann, (C) OREA)

Source: The Austrian Science Fund, https://www.fwf.ac.at/fileadmin/files/Dokumente/Ueber_den_FWF/BE_ OPEN/BE_OPEN_Nachlese_d.pdf 


\section{The Critique of Archaeological Economy \\ A Symposium (13-15 June 2018)}

"The Critique of Archaeological Economy-A Symposium", was held at the central building of the Austrian Academy of Sciences in June 2018 and attracted the interest of a wide scholarly audience. The organisers, Reinhard Jung (research group leader of the "Mediterranean Economies") and Stefanos Gimatzidis (ÖAI), had brought together twelve international specialists in the disciplines of anthropology, archaeology, history, and economy for a critical discussion of the dominant economic models applied to the study of past economic relations during the last two centuries and for the consideration of alternative theoretical trajectories.

A single and isolated individual driven by his or her economic agency has emerged in modernity in an imaginary free market. This had a profound impact on archaeological theory and interpretative praxis. Anthropological research has shown since the $19^{\text {th }}$ century that such "Robinsonades" lack foundations in well-documented pre-capitalist societies. Yet, archaeological theorising remains contingent on contemporary political and philosophical contexts. There

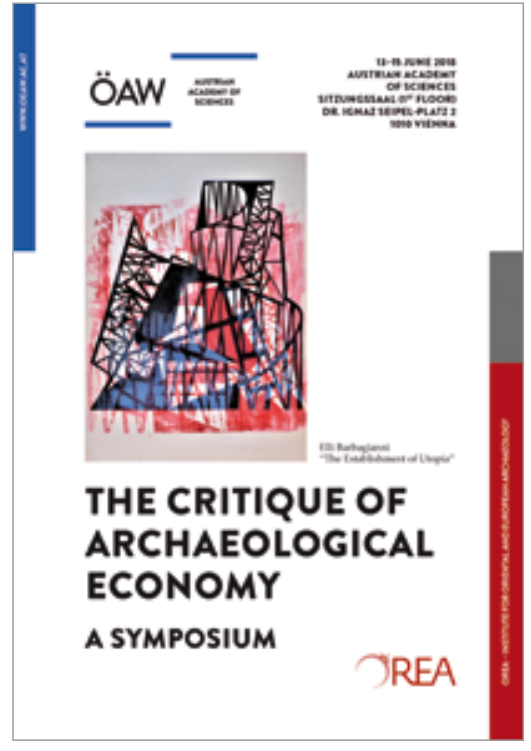

Fig. 24 Conference "The Critique of Archaeological Economy" (C OREA) are only a few academic fields in which interpretation depends so heavily on the theoretical methods and approaches engaged as in economic studies of the past. Therefore, a current challenge in archaeological interpretation is to become aware of several points of critique and reassert them in analytical praxis. Both the speakers in their talks and the audience in the discussions succeeded in questioning and transcending the limitations of the currently hegemonic discourse and in offering new critical and dialectic approaches to analysing past economic mechanisms and their underlying social contradictions (Figs. 24, 25).

The lively debates during the symposium went into depth on topics such as work by women, the appropriation of surplus and the role of force in the economy, counterstrategies against exploitative modes of production, problems in the conceptualisation of exchange value, the emergence of markets and their role under different historical conditions, as well as the potential of Marxist and feminist analytical approaches. The speakers addressed a wide array of theoretical

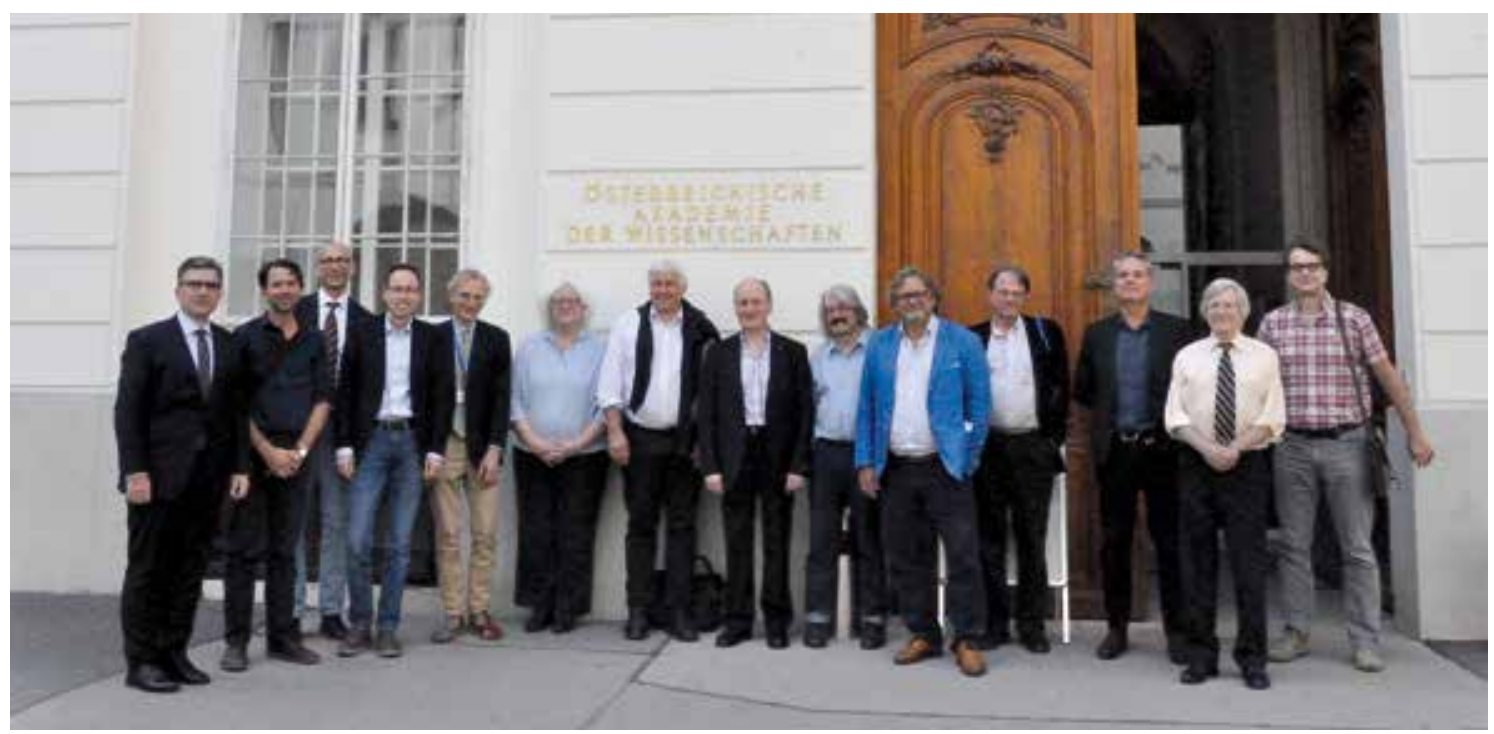

Fig. 25 Speakers of the conference The Critique of Archaeological Economy (photo: F. Ostmann, (C) OREA) 
issues with reference to concrete archaeological and historical data ranging from ancient Central America to Neolithic and Bronze Age societies in different parts of Europe and the Near East, Mesopotamia, Pharaonic Egypt and ancient Greece. Find the detailed programme and abstracts unter https://www.orea.oeaw.ac.at/fileadmin/Institute/OREA/Events/2018/CritiqueEconomy/ CritiqueEconomy_Program.pdf and https://www.orea.oeaw.ac.at/fileadmin/Institute/OREA/ Events/2018/CritiqueEconomy/CritiqueEconomy_Abstracts.pdf.

\section{Genes, Isotopes and Artefacts \\ How should we interpret the movements of people throughout Bronze Age Europe?} (13-14 December 2018)

This international conference, organised by Claudio Cavazzuti, Benjamin Roberts and Katharina Rebay-Salisbury, arose from the recent and rapid advances in genomic, isotope and archaeological research (Figs. 26, 27). New bio-archaeological and archaeometric data have provided complex, but frequently contradictory, perspectives on human mobility across Bronze Age Europe (2200-800 BC). Abstracts can be found under https://www.orea.oeaw.ac.at/fileadmin/Institute/ OREA/Events/2018/Genes/GenesIsotopesArtefacts_Abstracts.pdf.

Human mobility in European prehistory has traditionally been identified through artefacts rather than people. Interpretations of movement have frequently drawn upon distribution maps of artefact types across the continent or changes in recurring artefact assemblages in graves and settlements. Recent technological developments in genomic sequencing and isotope analysis on teeth/ bones have meant that debates concerning mobility have now shifted to direct evidence from humans (and animals). In addition, scientific developments in archaeological materials have enabled new perspectives on production and trade. Network analyses, which draw upon these and other new avenues of data, are starting to transform the Bronze Age map from a mosaic of static archaeological cultures to a mobile world of inter-dependent polities.

The aim of the conference was to identify the different scales, patterns and societal impacts of mobility throughout Europe. This international event brought together leading scholars from England to Russia and Sweden to Italy, tackling similar problems with different methods rooted in the humanities and natural sciences. As an inter-disciplinary forum, this event provided room for networking and discussions amongst the 110 participants. Videos of selected contributions are available on the OREA News Youtube channel https://www.youtube.com/playlist?list=PLmRZN1FA-ksaFQ_bSPy6L9bFQ1uC2Nv4q. Two essays have been published as follow-ups:

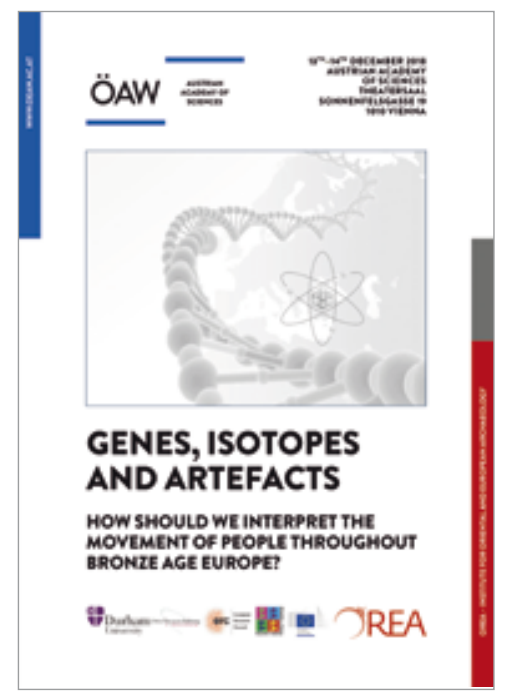

Fig. 26 Conference Genes, Isotopes and Artefacts (C OREA)

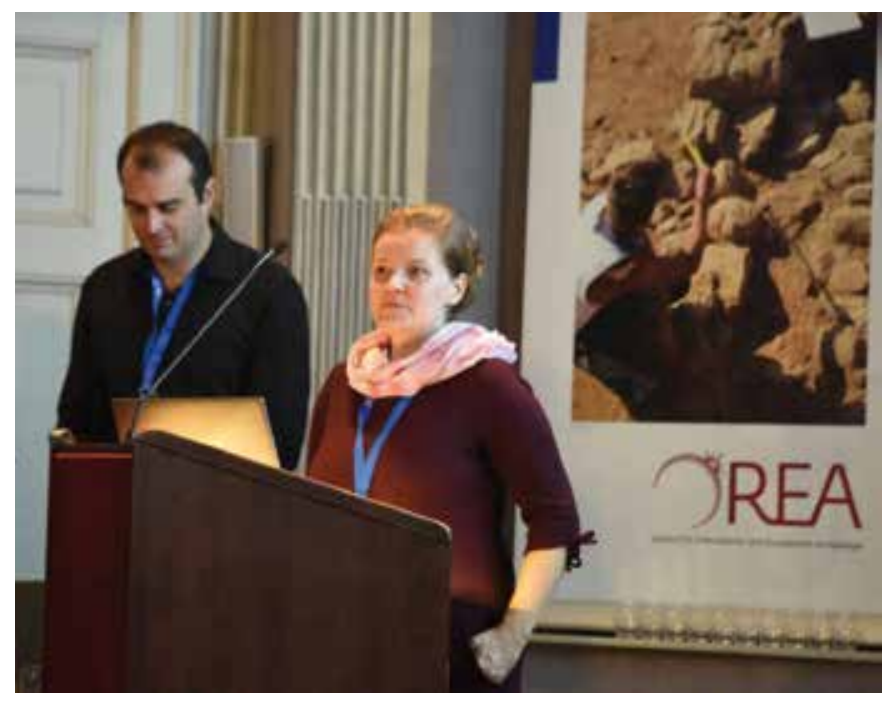

Fig. 27 K. Rebay-Salisbury and B. Roberts opening Genes, Isotopes and Artefacts (photo: F. Ostmann, (C) OREA) 
K. Rebay-Salisbury in "Der Standard BLOG 21.2.2019" (https://derstandard.at/2000098319987/ Mobilitaet-und-Migrationen-in-der-Bronzezeit) and B. Horejs in APA science 1/2019 (https://science.apa.at/dossier/Archaeologie_zwischen_genetischem_Goldrausch_und_ethischem_Dilemma/ SCI_20190131_SCI81335452246560650).

\section{$135+5$ Jahre}

140 Jahre Prähistorische Forschungen an der Österreichischen Akademie der Wissenschaften (18 December 2018)

The foundation of the "Commission zur Förderung prähistorischer Forschungen und Ausgrabungen auf österreichischem Gebiete" at the Austrian Academy of Sciences in 1878 was the beginning of a long and successful story of research (Fig. 28). In December 2018 OREA celebrated 135 +5 years of prehistoric archaeology, by combining the long history of the Commission with the recent transformation into a research institute 5 years ago. The Institute for Oriental and European Archaeology being the successor of the Commission.
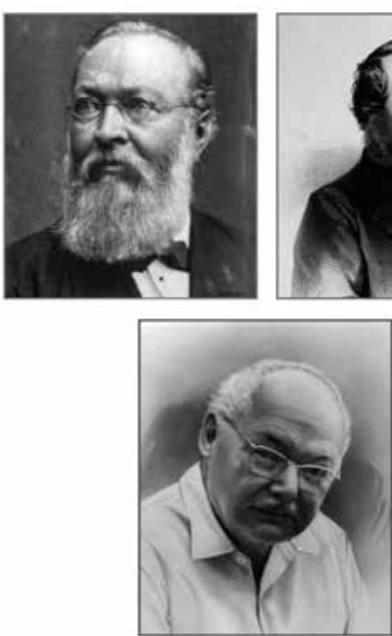
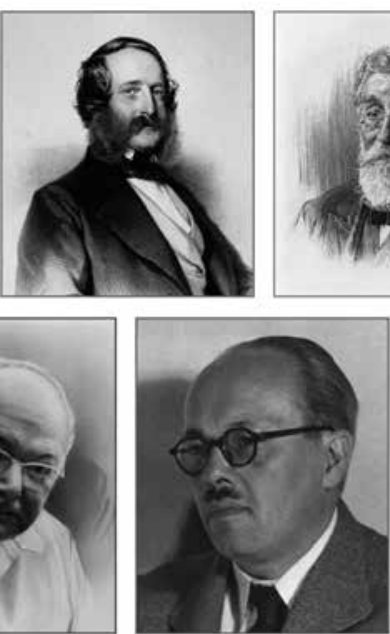
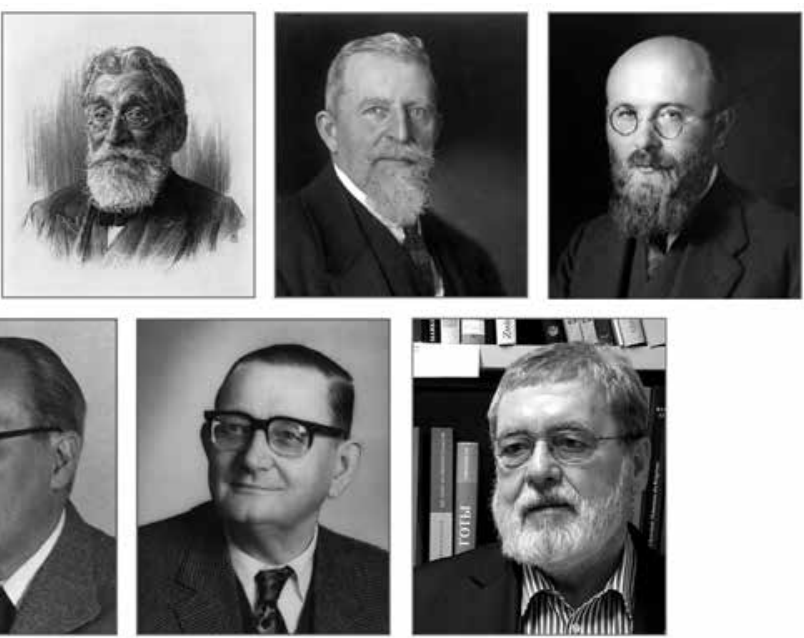

Fig. 28 Chairmen of the Commission from 1878 to 2012: Ferdinand von Hochstetter, Franz von Hauer, Franz Steindachner, Rudolf Much, Oswald Menghin, Josef Weninger, Richard Pittioni, Hermann Vetters, Herwig Friesinger (C AAS Archive)
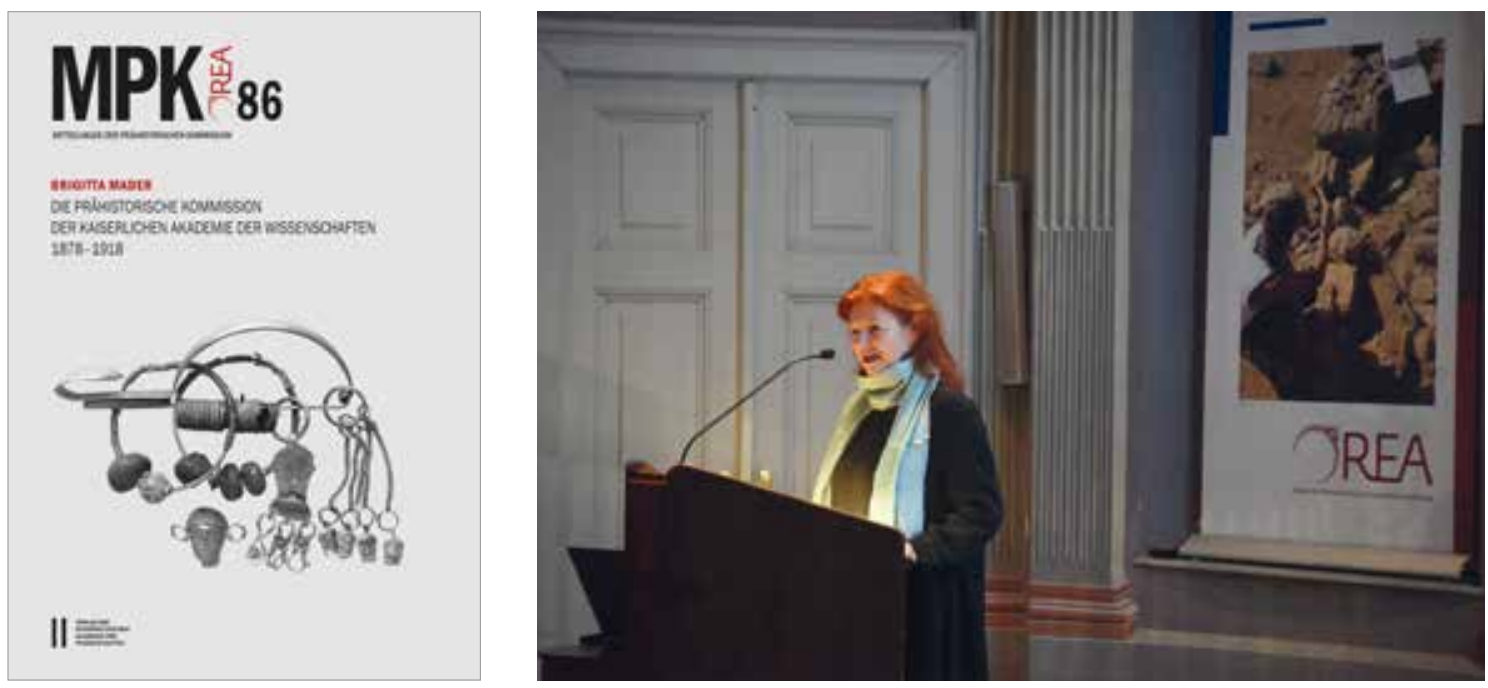

Fig. 29 Brigitta Mader, author of Die Prähistorische Kommission der kaiserlichen Akademie der Wissenschaften 18781918 , presenting the recently published monograph (photo: F. Ostmann, (C) OREA) 
The jubilee event was hosted at the historic premises of the Academy in the baroque Theatersaal, with more than 100 guests of honour and visitors. Representatives of the Presiding Committee of the Academy of Sciences, the FWF - the Austrian Science Fund - the Curt-Engelhorn-Zentrum and the OREA Scientific Advisory Board were amongst the key note speakers. Timed perfectly for the event, a substantial monograph "Die Prähistorische Kommission der kaiserlichen Akademie der Wissenschaften 1878-1918", presenting the results of a research project hosted at OREA, was hot off the press (Fig. 29). The author herself, Birgitta Mader, presented her research to the audience. This was followed by a joint reception, co-hosted by the Academy's publishers. The Austrian prehistoric scientific community, of whom many were present at the event, celebrated with OREA 140 years of successful prehistoric research at the Academy of Sciences.

\section{Making the Past Speak \\ OREA The Imagefilm}
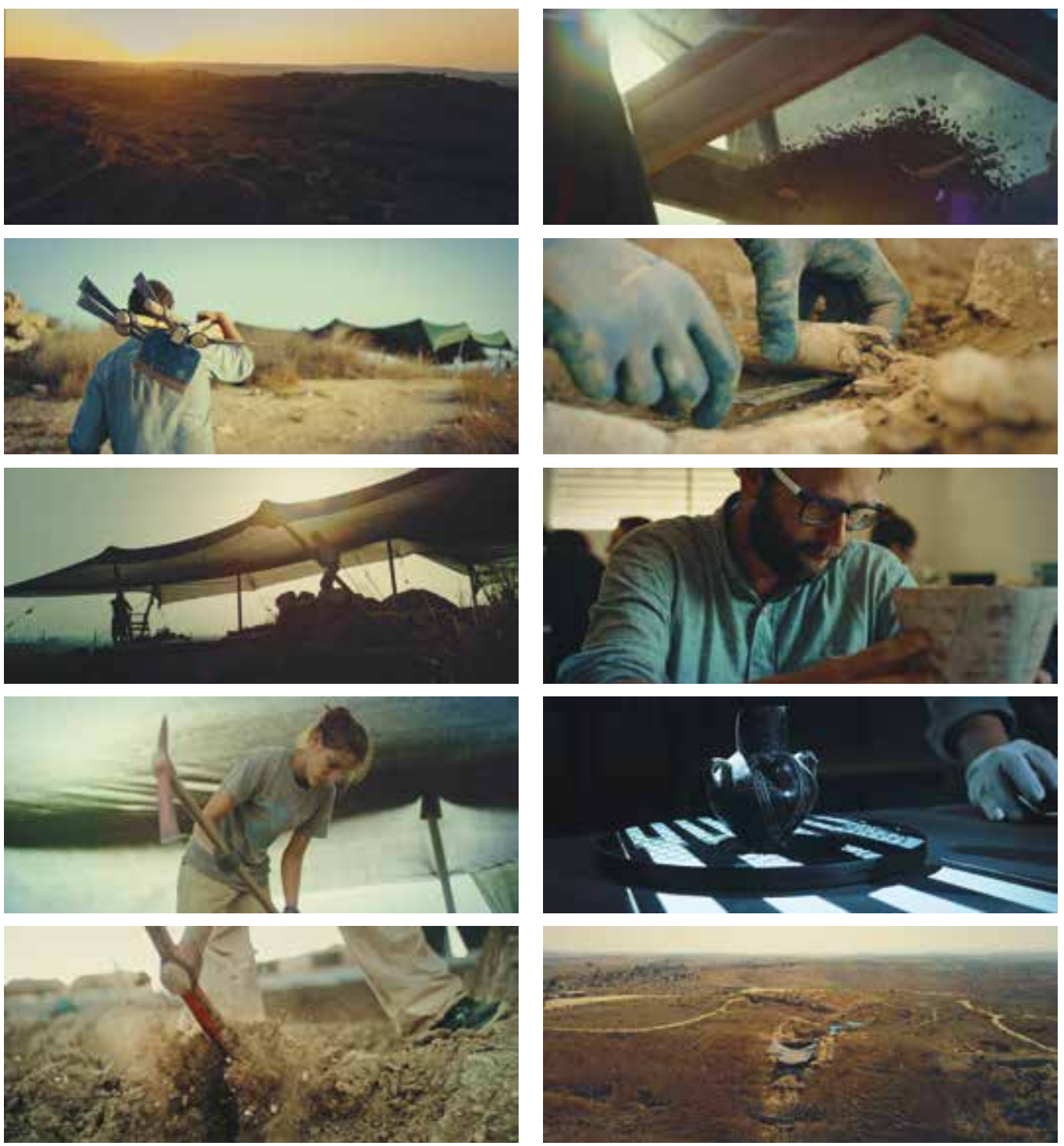

Fig. 30 You have questions? Come and look for me! Discover me! Bring me to light! I am waiting for you. In Europe, in the Orient. In 17 countries on three different continents.

You want to know who you are? Where you come from? Gather the most brilliant minds of your time and preserve my traces. Measure me. Analyse me. Study me under the microscope. Interpret me. Reconstruct me. Draw conclusions. Gain insight. Understand the big picture! And get ready for surprises!

You have questions? Come and look for me! Discover me! I am willing to answer them all. (photos: Querschuss, (C OREA) 
In August 2018 the production of the image film Making the Past Speak (Fig. 30) was launched after a short and very concentrated phase of concept development and preparation for the shooting. The shooting took place at excavation sites, as well as at the OREA premises.

The film had its premiere and first public performance in the presence of a large audience at the FWF BE OPEN Science Festival on September 8 (see above). Making the Past Speak was the first imagefilm going online for an institute of the AAS as well as the first of its kind for an archaeological institute in Europe. The

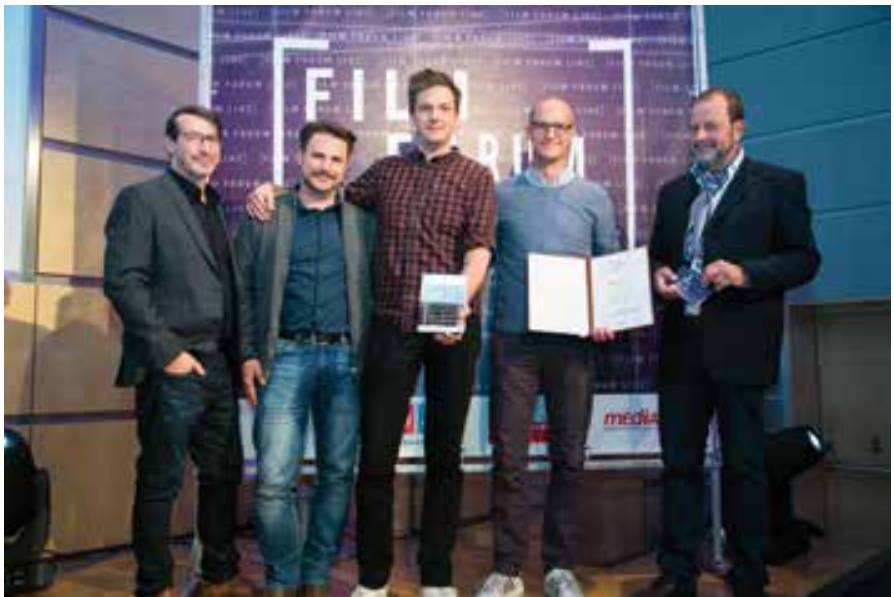

Fig. 31 Award ceremony Film Forum Linz, 16 December, 2018. Left to right: Karl Möstl (jury member Film Forum Linz), Viktor Schaider (camera), Christoph Petrik and Christoph Strobl (producers, Querschuss), Claus Muhr (Federal Economic Chamber Upper Austria and organizer of the Film Forum Linz) (photo: cityphoto.at, https:// www.cityfoto.at/content/de/fotogalerie/14454?img=1759177) producers, Christoph Petrik and Christoph Strobl (Querschuss) went into competition with the film at the Film Forum Linz. The Film was awarded Best Image Film 2018 on 16 December (Fig. 31).

\section{Establishing International Bilateral Contacts}

\section{Republic of Serbia}

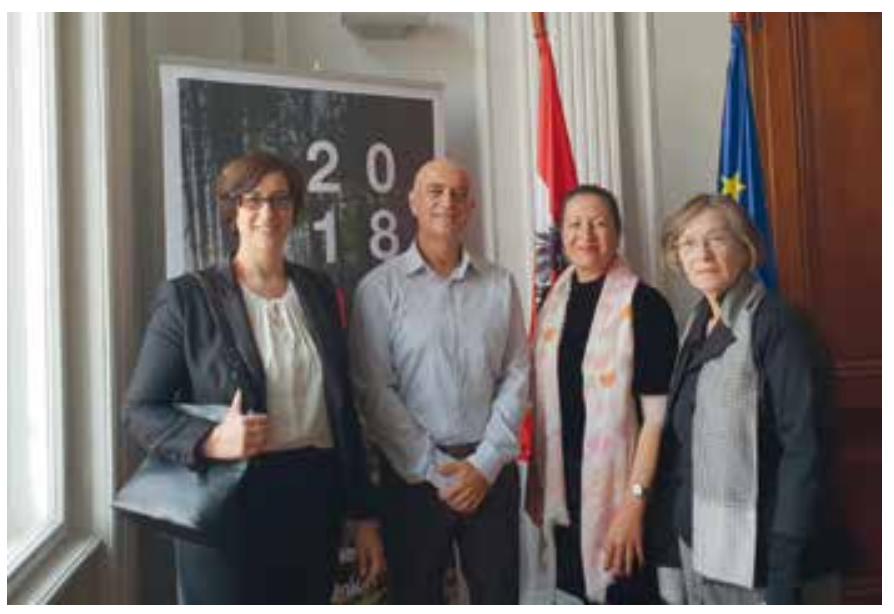

Fig. 32 Meeting at the Austrian Embassy, Belgrade. Left to right: S. Stefanović, A. Bulatović, B. Horejs, V. Bogosavljević-Petrović
In October Barbara Horejs was invited to join the Austrian Cultural and Scientific Delegation accompanying Alexander Van der Bellen, President of the Austrian Federal Republic, during his visit to the Republic of Serbia. The visit lasted from October 17 to October 18 and mutually stimulated contacts with colleagues from universities, museums and other scientific and cultural bodies. The National Museum, Belgrade - only recently reopened after long years of renovation - and the Historical Museum of Serbia were highlights of these meetings. The Austrian Embassy supported these initiatives with special receptions in the course of the visit (Fig. 32).

\section{Republic of Lebanon}

For the second trip in 2018 within the framework of the presidential visit to the Republic of Lebanon, Barbara Horejs joined the Austrian Cultural and Scientific Delegation from 10 to 13 December, 2018 (Figs. 33, 34). First steps towards strengthened contacts with the local adminis- 


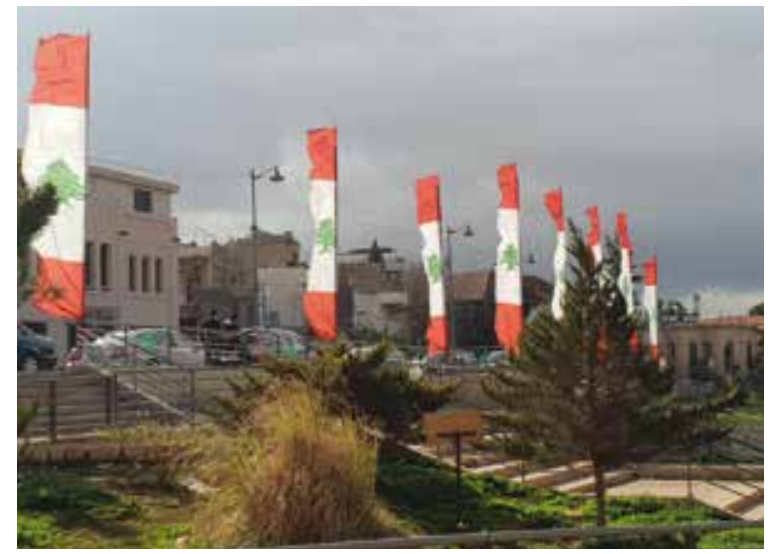

Fig. 33 State Visit to the Republic of Lebanon, autumn 2018 (photo: B. Horejs)

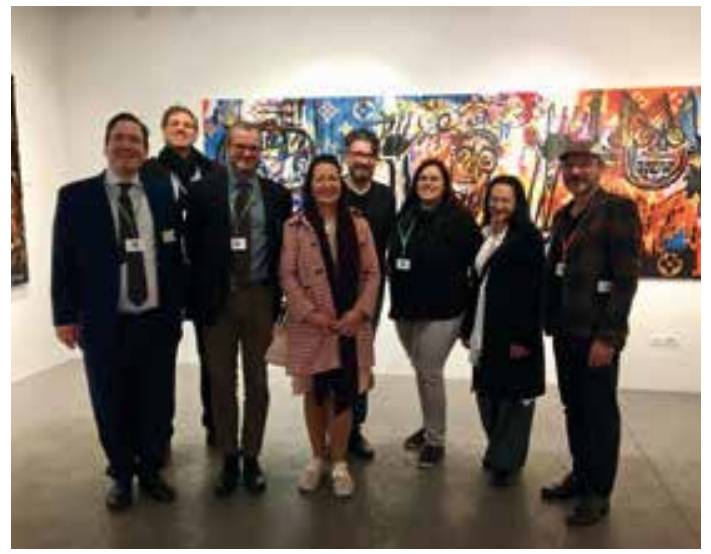

Fig. 34 The cultural scientific delegation at the Gallery of Contemporary Arts in Beirut, autumn 2018

trative authorities were successfully taken - fully supported by the organising team of the Austrian presidential office. The visit included meetings in Baalbek, Sidon and the Beirut National Museum as well the Umayad remains at Aanjar. Again the visit opened up new possibilities for bilateral cooperations with scientists and archaeologists. These contacts will facilitate excavation field work and help to establish good relations with the local authorities.

\section{Bosnia and Herzegovina}

On November 5, 2018, OREA together with H.E. Ambassador Martin Pammer, Austrian Ambassador in Sarajevo, presented a public evening under the motto "New Research in Bosnia and Herzegovina". Barbara Horejs and Mario Gavranović gave lectures on "Visualizing the unknown Balkans" and "New archaeological investigations in Bosnia-Herzegovina", complemented by posters on ongoing excavations in the region and a book presentation. A broad audience of Bosnian colleagues was invited and new initiatives and cooperations were discussed. Following the presentations the audience was invited to a reception at the ambassador's residence (Fig. 35).
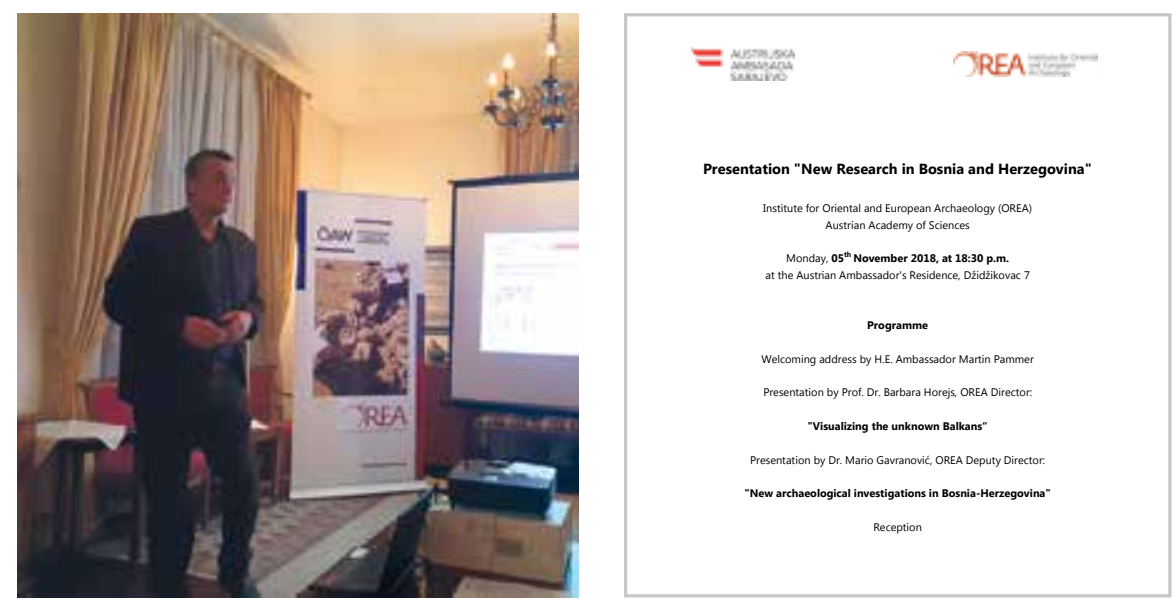

Fig. 35 M. Gavranović lecturing at the Austrian Embassy (photo: B. Horejs)

Barbara Horejs - Dagmar Melman - Ulrike Schuh - Angela Schwab 


\title{
Scientific Activity 2018
}

\author{
Quaternary Archaeology \\ (Research group leader: Thomas Einwögerer)
}

\begin{abstract}
Objectives
The Quaternary Archaeology research group focuses on investigation of the hunter-gatherer cultures of the Ice Ages. The main field of research covers open air sites which are well-preserved in the loess sediments of the Middle Danube region's river systems. Ongoing fieldwork (Kammern-Grubgraben, Kamegg), as well as concluded field investigations (e.g. Krems-Hundssteig, Krems-Wachtberg, Gösing-Setzergraben, Schiltern) in Lower Austria provide a large database for Ice Age research. The occupation span, structure, and function of the individual sites are reconstructed on the basis of this data, in conjunction with interdisciplinary analyses (e.g. raw material studies, physical anthropology, ancient DNA) and comparison of regional and supra-regional cultural developments and climatic changes. Located amid the best known Palaeolithic sites of Lower Austria, the branch in Krems functions as a research platform and provides enough space for material studies, in particular for ther (re)assambling of the vast lithic inventories of KremsWachtberg and Kammern-Grubgraben.
\end{abstract}

\section{Current research}

After 10 years of field investigations from 2005 to 2015, the Gravettian open air site Krems-Wachtberg still constitutes an important focus of the Quaternary Archaeology research group. In addition to a large number of finds, including not only lithics, animal hard tissue remains, and charcoal, but also adornments and mobile art, the excavations also documented spectacular and unique features. A double burial of newborns and the single grave of a 3-4 month-old infant must be considered the most significant among these. Furthermore, two hearths, as well as a number of pits of various sizes have been documented. In particular, the burials established the international fame and significance of this Lower Austrian open air locality as a key reference site for the investigation of Ice Age environmental and climate conditions in the Middle Danube Region during the Upper Palaeolithic. State-of-the-art excavation standards, single artefact recording, and the organisation of all datasets in one central database allow for addressing issues such as social structure, subsistence, and mobility. Furthermore, questions concerning the production processes of different materials ranging from lithics to bone, ivory, and pigments, can be targeted. Research is now being conducted towards analyses, evaluation, and publication of the data. At present, the work is focusing on a comprehensive presentation of the lithic industry encompassing raw material procurement, artefact morphology, as well as the entire chaîne opératoire of both the flake industry and the cores. Extensive refittings carried out in recent years provided a crucial basis for the technological assessment. Analyses and publication of the finds and features of the Krems-Wachtberg excavations are receiving substantial financial support from the Federal State of Lower Austria. At the moment, support is secured until 2021. This will result in a number of monographs, beginning with a volume on the lithic industry. Another important topic of investigation comprises the analysis and publication of the double burial of newborns. The extraordinarily well-preserved feature enables detailed anthropological assessment of stress events, age at death, as well as reconstruction of kinship and descent through human DNA. A manuscript is currently in preparation and will be submitted to a high-ranked journal in cooperation with Maria Teschler-Nicola 
(NHM, Natural History Museum Vienna, Dept. of Anthropology) and Ron Pinhasi (University of Vienna, Dept. of Anthropology).

Furthermore, a pilot study "Digitalisation as a chance for restoration and visualisation - A pilot study on the 30,000 year old double burial of newborns from Krems-Wachtberg" in cooperation with Dieter Pahr (Karl Landsteiner University, Krems), Maria Teschler-Nicola (NHM), and Anja Grebe (Danube University, Department for Arts and Cultural Studies) commenced in November 2018. The study is funded by the research, technology and innovation programme (FTI Call of the NÖ Forschungs- und Bildungsges.m.b.H. NFB) of the Federal State Government of Lower Austria and aims at a 3D reconstruction of the infants' skeletal remains based on high-resolution micro-CT data. The method allows for a digital reconstruction of both the surface and internal micro-structure of bone elements and teeth. Digitisation of the skeletal elements will thus enable future non-invasive investigations on the digital model. In addition, the project's scope includes exploration regarding enhancement of 3D documentation and development of a state-of-the-art catalogue of criteria for long-term archiving of 3D data and creation of an open-source archive. The research group also participated, with both finds and samples as well as research questions regarding micro-taphonomy at Krems-Wachtberg, in a project proposal for an ERC starting grant "Early modern human taphonomy: A new methodological approach to human remains" submitted by Sandra Sázelová (Research Centre for the Palaeolithic and Palaeoanthropology, Institute of Archaeology, Academy of Sciences of the Czech Republic, Brno).

In August and September 2018, fieldwork resumed at the Epigravettian site of Kammern-Grubgraben (Fig. 36) where investigations have been carried out by the research group since 2015. Research is co-funded by the Federal State of Lower Austria. As in previous years, a field school was conducted for the Institute of Prehistoric and Historical Archaeology of the University of Vienna. According to the original permit negotiated with the landholder (Weingut Gobelsburg) in 2015, this was to be the last campaign at the site. Several fieldwork campaigns between 2015 and 2017 documented a number of excavation trenches in different positions at

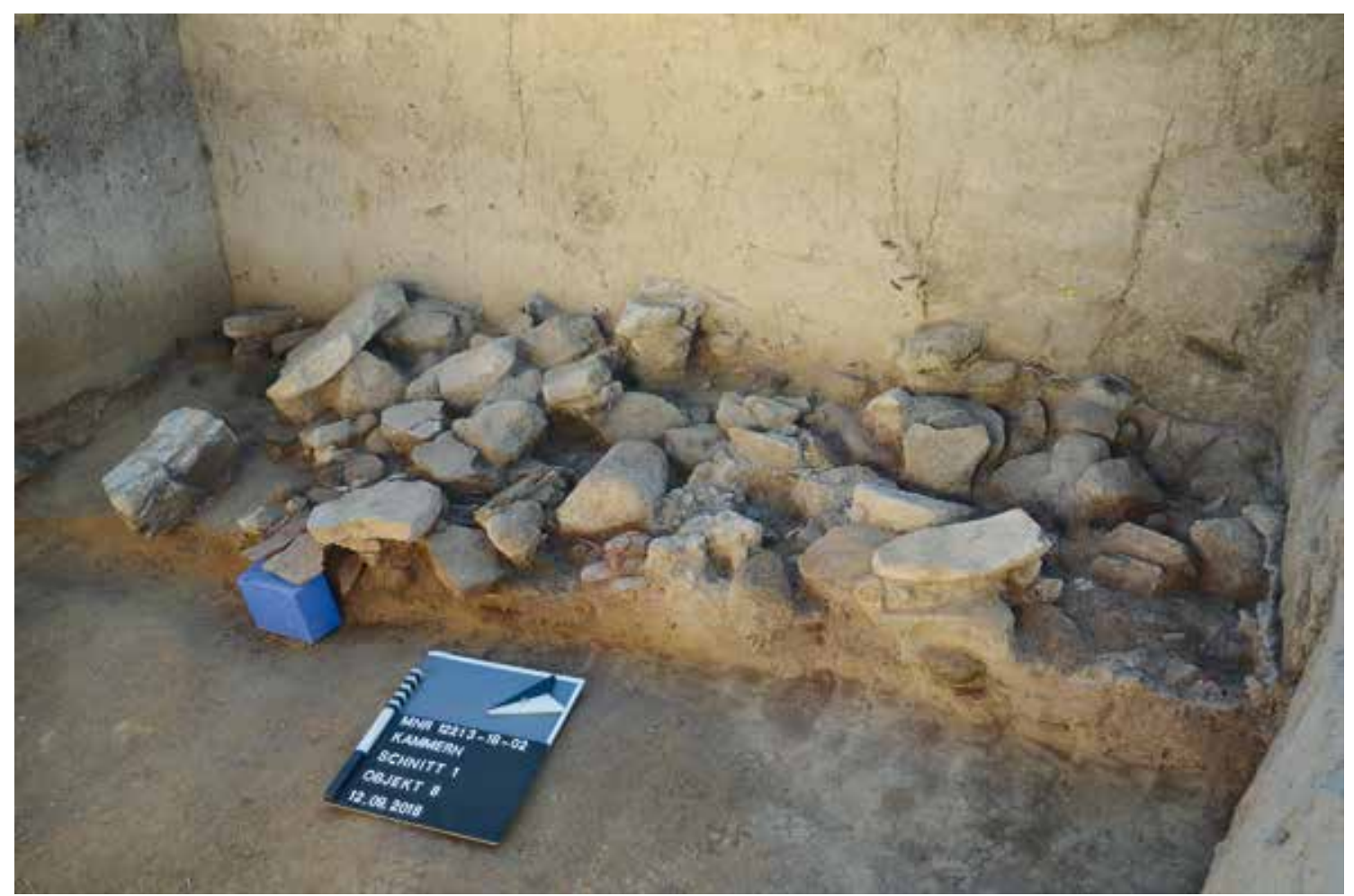

Fig. 36 Kammern-Grubgraben, Lower Austria, Trench 1, collapsed stone structures (photo/C OREA) 
this important site dating to the Last Glacial Maximum (around 19,000 BP). In 2015 and 2016, an extensive pavement of stone slabs was documented in a previously uninvestigated area on the site's southern fringe. In 2016 and 2017, a stratigraphic sounding originally investigated by Paul Haesaerts in 1986 was re-opened and extended. This trench (Trench 'Paul') documented a stone slab pavement together with an extraordinarily high density of finds and a number of small anthropogenic pits, presumably postholes. The find layer most probably represents cultural layer sequence AL 2-4 as defined in 1985-1994 when previous excavations were carried out by Anta Montet-White and Friedrich Brandtner. In 2016, excavation commenced at a new $1 \times 3 \mathrm{~m}$ trench (Trench 1). Here, for the first time in the course of recent investigations, it was possible to capture an extensive part of layer AL 1, which had been recorded during the excavations from 1985-1994, and to collect dateable material. During the 2018 campaign, excavations concentrated on both a $10 \mathrm{~m}$-long exploratory trench aiming at a stratigraphic connection of Trench 'Paul' with the stone slab pavement in the south, and Trench 1 where a thick stone package representing cultural layer sequence AL 2-4 was exposed. Here, unlike in the other trenches, not simply a pavement of one layer of stone slabs was recorded but instead the remains of rising stone constructions with up to 5 stone slabs preserved atop each other. Structural stone collapse documented that the construction had originally been larger and higher. Due to the extraordinary results, in particular the stone structures in Trench 1, the Austrian Bundesdenkmalamt (BDA) supported a new arrangement with the landholder to allow for another 3 years of field investigations, until 2021. The hitherto recovered lithics confirm an assignment to the Epigravettian/Badegulian.

In order to analyse the enormous body of finds from the previous excavations from 19851994 which were recently recorded in a database for comparison with the results from the ongoing investigations, a D-A-CH project proposal "Living on the edge - Success, limits and

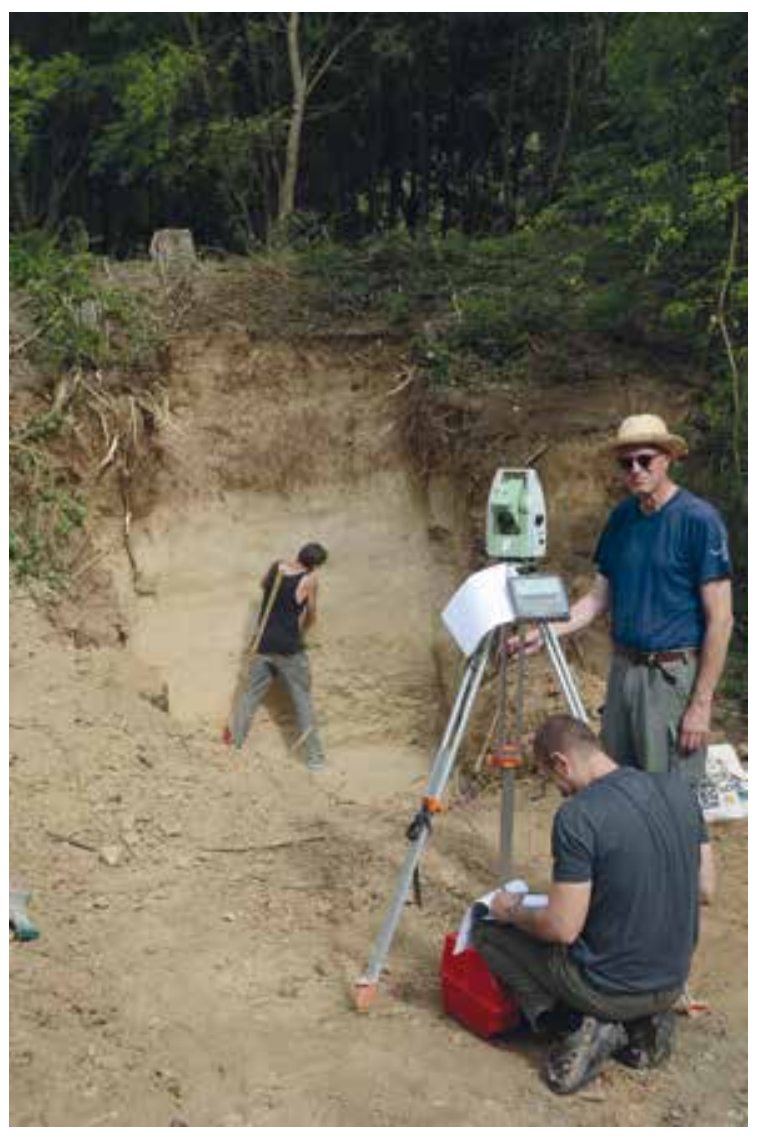

Fig. 37 Kamegg, Lower Austria, Alte Ziegelei, documentation of Profile 1 (photo/C OREA) failure of adaptive strategies in eastern Central Europe during the Last Glacial Maximum" was submitted to the German Research Foundation (DFG) and the Austrian Science Fund (FWF) in cooperation with Kerstin Pasda, Andreas Maier, and Christoph Mayr (all Friedrich-Alexander University, Erlangen-Nürnberg). Furthermore, in order to sort, identify, and digitise the previous excavation's documentation material and clarify the numerous inconsistencies in the 1985-1994 investigations, a second project proposal "Digitising Kammern-Grubgraben" was submitted to the research, technology and innovation programme of the Federal State Government of Lower Austria (FTI Call of the NÖ Forschungs- und Bildungsges.m.b.H. NFB).

In the run-up to construction of an access road, laying a sub-surface power supply line, and preparing plots for housing, the Quaternary Archaeology research group conducted field investigations at the wellknown Upper Palaeolithic site of Kamegg, Lower Austria (Fig. 37). In the course of clay quarrying at the be ginning of the $20^{\text {th }}$ century, lithic artefacts, animal bones and 


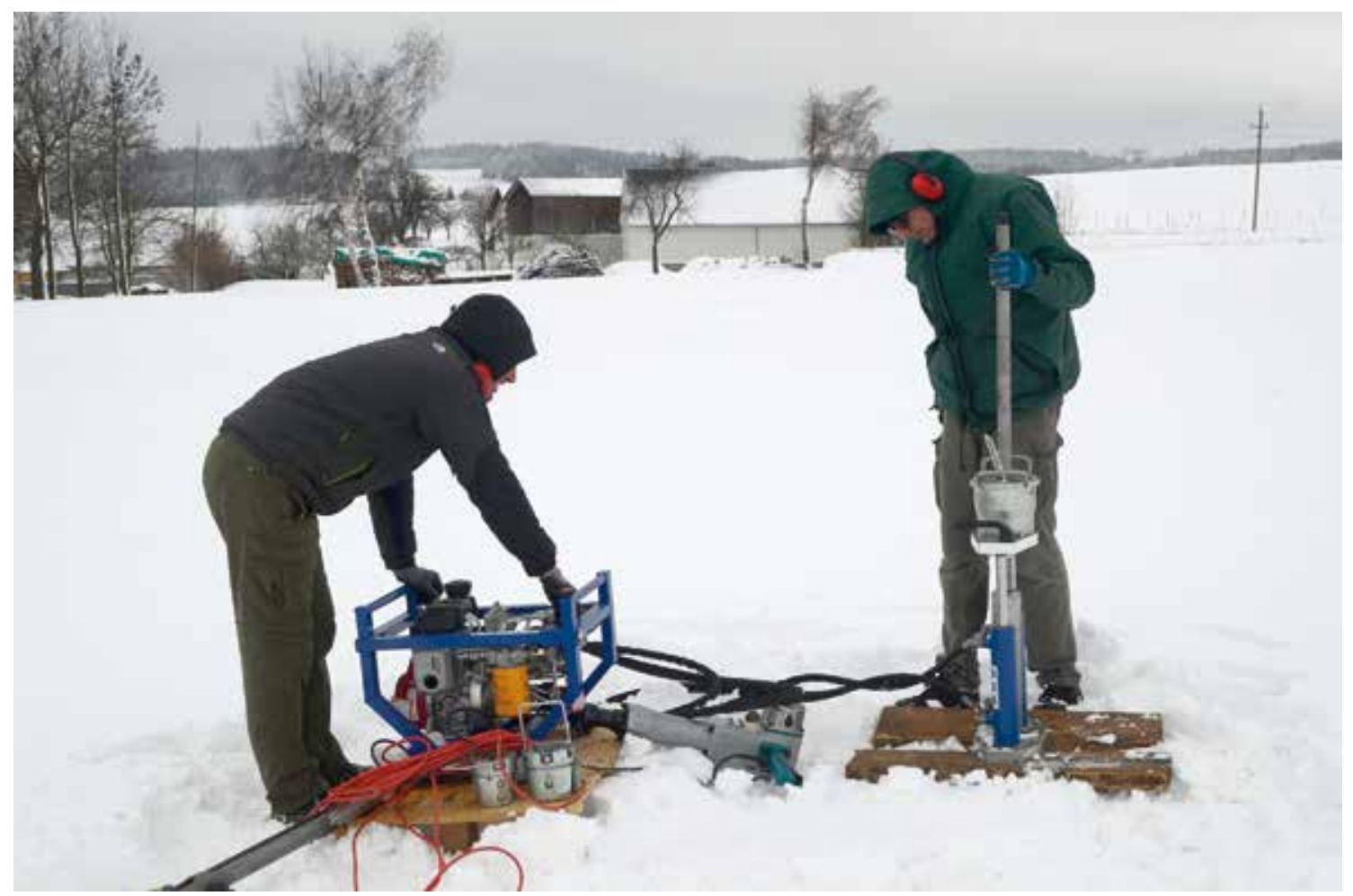

Fig. 38 Brunn am Wald, Lower Austria, core sampling in adverse weather conditions (photo/C OREA)

antler have been recovered, as well as pavements of stone slabs reported. The site is dated to around 15,000 BP. For the most part it had been destroyed by the quarrying of clay for brick production. In the early 1980s however, small-scale soundings by Friedrich Brandtner and Anta Montet-White established that archaeological remains are still present. Unfortunately, comprehensible documentation does not exist for these investigations. In June 2018, the research group was commissioned to clarify the stratigraphy and archaeological potential. A four metre-high profile was created and a number of core soundings conducted. This documented that in some areas, Palaeolithic layers are still intact. Furthermore, the soundings of the 1980s were localized and recorded, as well as samples for radiocarbon dating recovered. The investigations contributed to supplementing the sparse data known from the previous excavations and to spatially capturing the soundings in the official grid. Of special interest is the confirmation of preserved archaeological layers providing potential for future investigations.

The Quaternary Archaeology research group was also commissioned and financed to carry out field investigations at a site known since the 1980s, Brunn am Wald near Lichtenau in Lower Austria. In the course of several years, amateur collectors had gathered lithic objects made of yellow chalcedony from the surface, which they classified as Aurignacian artefacts. A planned land sale and development rendered archaeological assessment necessary. The first step was a systematic surface survey carried out in the form of a line walk with 3-dimensional total station recording of the objects collected. This was followed by core sampling (Fig. 38). Unfortunately, no preserved archaeological layers were evidenced. In addition, the lithic objects collected exhibit features of geofacts, or plough artefacts, rather than of intentionally knapped implements. Brunn am Wald is a site from the so-called 'Plateaulehmpaläolithikum'. These sites are characterised by outcrops of lithic raw materials, in this case yellow chalcedony. Due to a lack of substantial sedimentation, these sources have been accessible for millennia and have thus often been used throughout prehistory. Today's use of heavy agricultural machinery leads to continuous unintentional 'extraction' of fragments from these outcrops and production of plough artefacts. 
As in previous years, a quantity of coursework on Palaeolithic topics was provided by members of the research group at the Institute of Prehistoric and Historical Archaeology of the University of Vienna (C. Neugebauer-Maresch, T. Einwögerer, M. Brandl). The topics of the lectures included identification of Palaeolithic and Mesolithic stone tools, methods for analyses of Palaeolithic stone tools such as artefact morphology and archaeometry, raw material analysis and economy, as well as a field school.

2017-2018 saw a close cooperation with the State Museum of Prehistory in Halle, Germany. A selection of mammoth ivory beads from the double burial of Krems-Wachtberg was presented as part of the special exhibition "Climate Powers - Driving Force of Evolution".

\section{Highlights 2018}

- Start of the pilot project "Digitalisation as a chance for restoration and visualisation - A pilot study on the 30,000 year-old double burial of newborns from Krems-Wachtberg" in cooperation with Dieter Pahr (Karl Landsteiner University Krems), Maria Teschler-Nicola (NHM), and Anja Grebe (Danube University, Department for Arts and Cultural Studies). It is funded by the research, technology and innovation programme of the Federal State Government of Lower Austria (FTI Call of the NÖ Forschungs- und Bildungsges.m.b.H. NFB), and aims at a $3 \mathrm{D}$ reconstruction of the infant remains based on high-resolution micro-CT data. Digitisation of the skeletal elements will thus enable future non-invasive investigations on the digital model. The project also aims at enhancing 3D documentation and development of a state-of-the-art catalogue of criteria for long-term archiving of 3D data as well as creation of an open-source archive.

- Excavations at Kammern-Grubgraben evidenced that, in addition to extensive one-layer stone slab pavements, the site is also characterised by the presence of rising Upper Palaeolithic stone constructions. For the time period this is absolutely unique. The finding provided the decisive argument for convincing the landholder (Weingut Gobelsburg) to provide permission for a further 3 years of field investigations at the site, until 2021. This provides the opportunity for a much better assessment and interpretation of the feature.

- Field investigations at the well-known Upper Palaeolithic site of Kamegg substantiated the presence of intact archaeological layers, albeit most of the site had been destroyed by clay quarrying. This provides substantial potential for future fieldwork and to collect data for a timespan poorly represented in Austria (between the LGM and Younger Dryas). 
Prehistoric Phenomena

(Research group leader: Barbara Horejs)

\section{Objectives}

From the Holocene to the beginning of the Metal Ages (c. the $10^{\text {th }}$ to the $3^{\text {rd }}$ millennium BC) crucial changes in human society and ways of life took place in the vast area extending from the Middle East to south-eastern Europe. These developments include the profound and long lasting change towards the oldest sedentary agricultural cultures of the Neolithic period and the incipient shaping of the natural environment by humans associated with a fundamental change of communal organisational structures. This process of Neolithisation proceeds differently according to the region and starts between c. 9500 and 6000 calBC. The changes in socio-cultural structures of these early farming communities until the formation of early proto-urban communities during the Chalcolithic and Early Bronze Age period reflect a fundamental shift, which is evidenced by the appearance of various, simultaneous innovations. The development and adoption of essential technologies is tightly connected with the management of resources whose use again varies regionally. The Metal Ages, defined by regional differences, are related to the phenomena of centralisation, specialisation and new dynamics of mobility. These fundamental processes of human history are investigated by an interdisciplinary methodological approach on a supra-regional level. The aim is the development of models on the basis of new, primary datasets which are gained through in-house field investigations.

\section{Area of Investigation}

The phenomena of Neolithisation, centralisation, resource management, technologies and innovations are a key focus of a number of research projects. These are, moreover, regionally and supra-regionally contextualised in the framework of communication systems and networks. The civilizational core zones of the Old World are the focus of Prehistoric Phenomena. The individual

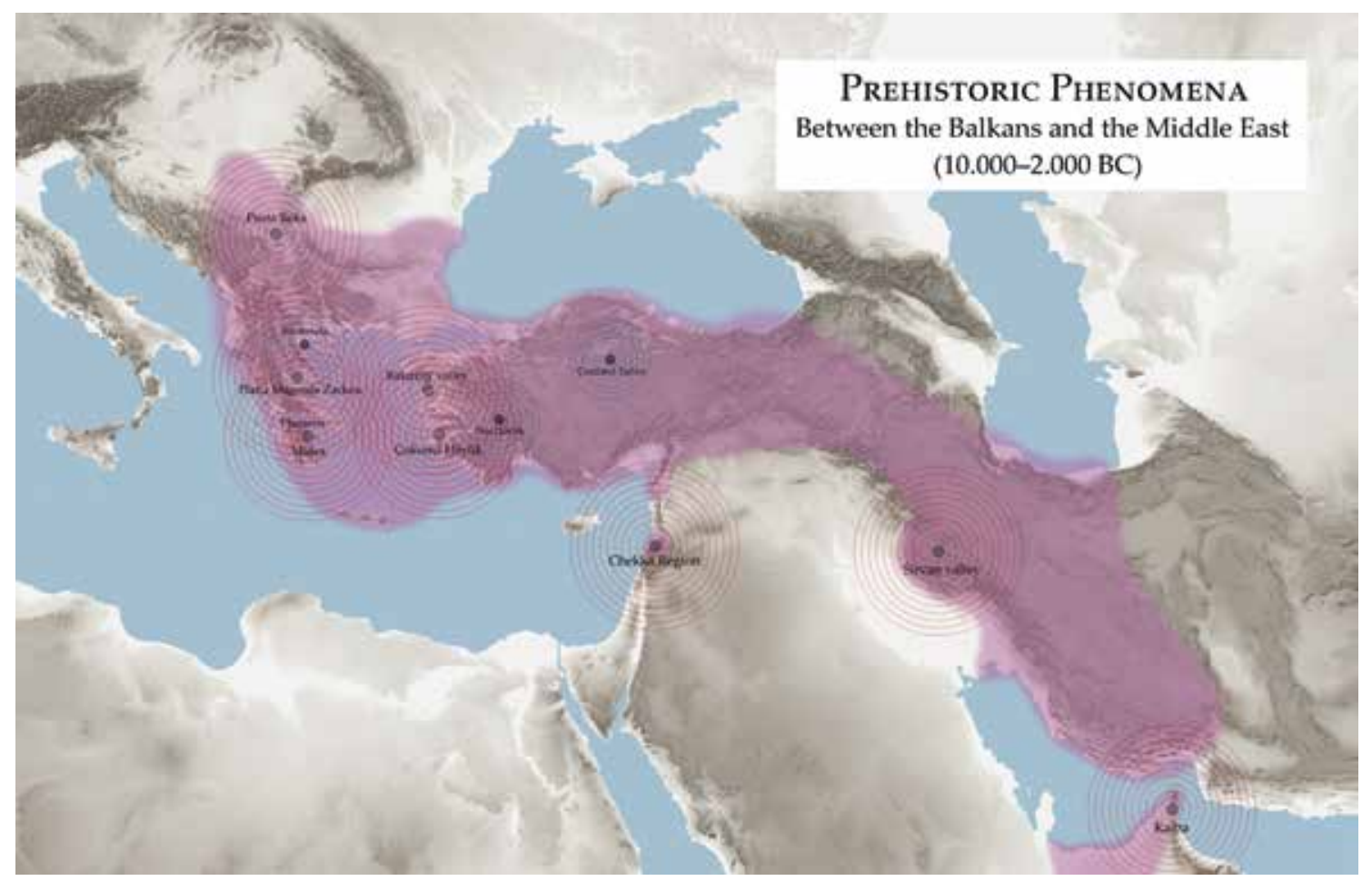

Fig. 39 Areas of investigation of Prehistoric Phenomena (December 2018; map: M. Börner, Ch. Schwall, (C) OREA) 
cultural regions include the Fertile Crescent (Iran, Turkey), the Levant (Lebanon), the Arabian Peninsula (UAE), the Aegean (Greece) and the Balkans (Serbia, Northern Macedonia). Besides in-house field investigations in these regions, individual case studies are embedded in various cooperations within broad international research projects (Fig. 39).

The range of methods includes excavations, surveys and landscape analysis, as well as material studies combined with geoarchaeological disciplines (paleogeography, geophysics, and geology), radiocarbon dating, zoology, anthropology, botanics, anthracology, metallurgy, aDNA, petrography/mineralogy, geochemical analyses (i.e. NAA, pXRF, pLA-ICP-MS), and computer simulations/data modelling.

\section{Current research}

\section{Process of Neolithisation $\left(10^{\text {th }}-7^{\text {th }} / 6^{\text {th }}\right.$ mill. BC)}

The essential processes of sedentism, the cultivation of animals and plants as well as all socio-economic changes that can be summarised as Neolithisation, are highly debated in the regions of our focus from the Balkans to the Middle East. Modern excavated data from the early $7^{\text {th }}$ millennium site Çukuriçi Höyük in Western Anatolia are currently being used for multiple interdisciplinary and extended studies focusing on the initial starting point of first settlers in the region and their potential origins. For this approach, a new collaboration with the title 'Pathways to the Late Neolithic of Central and Western Anatolia' between the Çukuriçi Höyük and Çatalhöyük projects (in cooperation with Çiler Çilingiroğlu, Ege University; Arkadius Marciniak, Poznan University) was initiated with a workshop in October 2018. The aim is to bring the results of both projects together and analyse potential connections and changes during the Late Neolithic period in this broader region. Important for this collaboration is the research on settlement phase ÇuHö VIII at Çukuriçi Höyük, which is currently being prepared for publication.

Investigations on lithic raw materials from Çukuriçi Höyük have been continued. Bogdana Milić submitted and successfully defended her PhD thesis on the topic of 'Lithics and Neolithisation - Çukuriçi Höyük in Anatolia and the Aegean' in Tübingen in November 2018. The thesis will be prepared for publication as a monograph.

In May 2018 'The Prehistoric Sirvan Project' in the highlands of the Central Zagros started with the extensive and intensive archaeological surveys in the province of Ilam (western Iran). This project is led by Barbara Horejs, cooperating with the Iranian partner Lily Niakan (ICAR Iranian Center for Archaeological Research), and is embedded in the larger project of the Austrian Academy of Sciences, with Florian Schwarz (The Institute of Iranian Studies) and Andreas Pülz (The Institute for the Study of Ancient Cultures). The pilot campaign in 2018 aimed to define all potential prehistoric sites in the Sirvan Valley. The first results offered an overview of the prehistoric activities in this micro-region, where a range of sites dating to the Paleolithic, Pre-Pottery (PPN) and Pottery Neolithic (PN), Chalcolithic and Bronze Age have been recorded and documented. Additionally, a smaller survey has been conducted in the neighbouring Chardavol Valley, with the inspection of the PPN tell site of Chogha Khaki, and its surroundings. Based on the archaeological, environmental and geological surveys, topographical locations and the study of finds, the first mapping of prehistoric sites in the previously unexplored area of Sirvan and further Chardavol Valley was undertaken, showing a strong potential for further investigations in this part of the Zagros Mountains. Further expeditions concerning work on several recognised promising locations are planned for the near future, with a focus on understanding the process of formation and development of the Neolithic in the region.

Based on the results of an initial survey campaign in 2017, first excavations at the newly detected site Svinjarička Čuka took place in August and September 2018 in the course of the new 'Pusta Reka Project' by Barbara Horejs in collaboration with Aleksandar Bulatović (Archaeological Institute Belgrade) and the Museum of Leskovac, in order to investigate the Neolithic landscapes of the Pusta Reka region near the city of Leskovac in southern Serbia. The excavations of two trenches yielded information about horizontal and vertical stratigraphies 


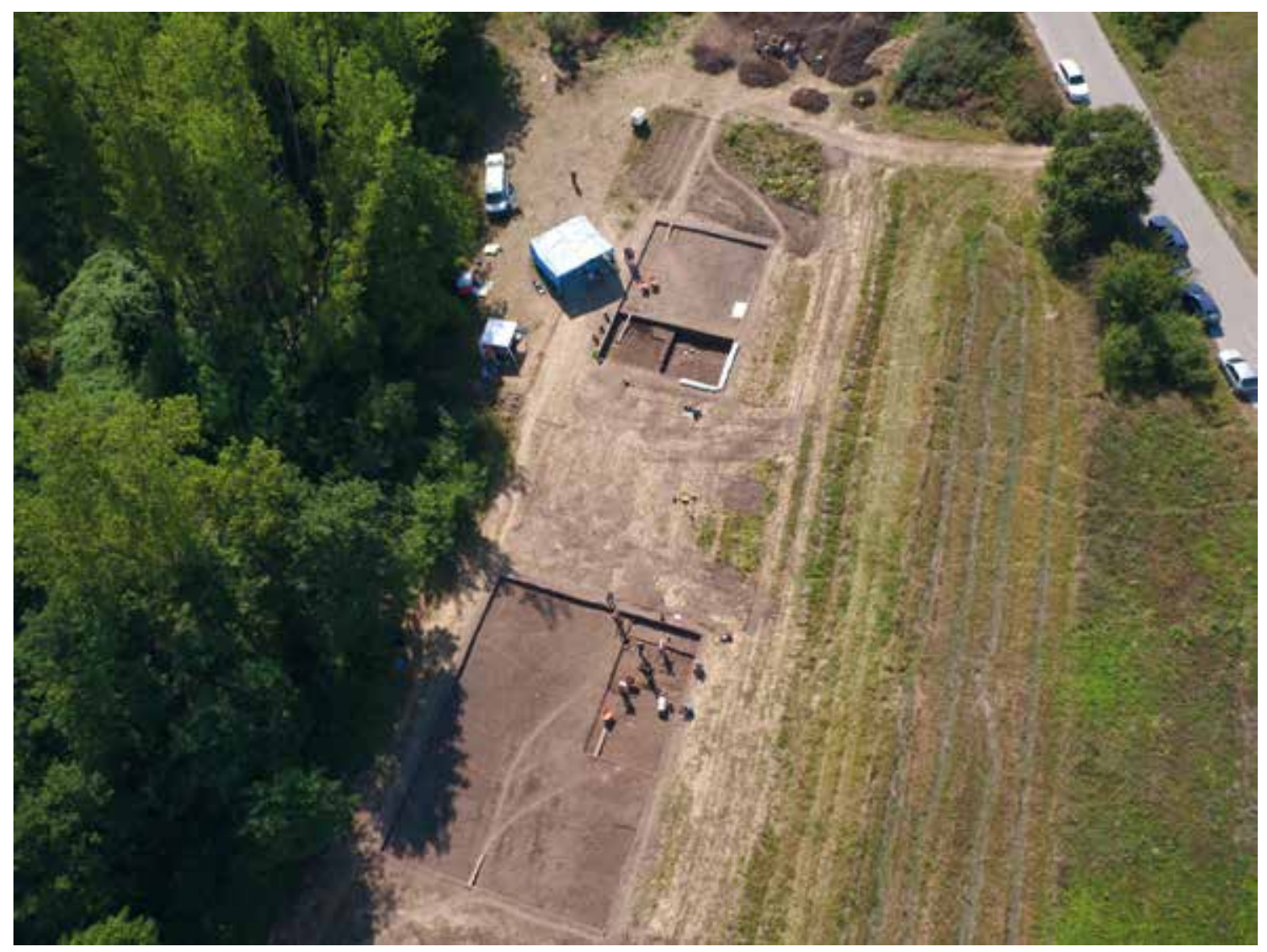

Fig. 40 Excavations at Svinjarička Čuka/Serbia (photo: M. Börner, (C OREA)

present at the site, which was presumably occupied in the Iron, Bronze and Copper Ages, as well as in the Early to Middle Neolithic, i.e. Starčevo culture (Fig. 40). The first results of the excavations confirmed some of the survey outcomes, in particular those concerning the dating and site formation. The materials, GIS analyses and geo-archaeological results of the 2017 surveys have been accomplished and published (Horejs et al. 2018). A study season and the continuation of the excavations are planned for 2019 within the projects Pusta Reka and Visualizing the unknown Balkans.

Additionally, the characterisation of Early Neolithic chert resources in the Pusta Reka region has been continued by Michael Brandl (cf. Raw Material Lab). The aim is to reconstruct the Early Neolithic resource management strategies through the characterisation of local versus non-local raw materials in lithic assemblages from this region in order to answer questions concerning the use of the prehistoric landscape of this micro-region.

The study on the Neolithisation processes in Anatolia, the Aegean and the Balkans based on the appearance of new emerging technologies and their possible inter- and supra-regional transfer took place in 2018 with new collaborations between OREA Neolithic specialists and external partners. A first study season on the new Neolithic material (chipped stones) from the $7^{\text {th }}$ mill. BC site of Ekşi Höyük (Denizli province, inner west Anatolia) directed by Fulya Dededoğlu from the Ege University in Izmir was undertaken by Bogdana Milić. This sub-project tends to contribute to understanding of the broader area of western Anatolia in the spread of the Neolithic focusing on lithic technologies, which includes a larger comparative study on the primary data sets, combining lithics from Ekşi and Çukuriçi Höyük studied first hand. Bogdana Milić and Michael Brandl conducted a first analysis on lithic technology and raw material use at the Early Neolithic site of Paliambela in northern Greece, directed by Kostas Kotsakis (Aristotle University of Thessaloniki). Paliambela has been recognised as one of the pioneer sites in 
the Aegean in the context of the emergence of the Neolithic in the $7^{\text {th }}$ millennium BC. The preliminary results of the study of the finds provide information about a slightly distinct concept of production and use of chipped stones in Northern Greece, comparing it to the eastern Aegean, where further attempts at the cultural contextualisation of the broader $7^{\text {th }}$ mill. Aegean Neolithic are planned. Finally, the analysis of the Early Neolithic lithics and pottery technologies, as well as the use of raw materials in the Balkans have been enriched via a new cooperation within the already existing partnership with the Archaeological Museum of Macedonia in Skopje, with the visit of Bogdana Milić, Clare Burke and Michael Brandl to Macedonia in autumn 2018. Future study of the materials available in the museum is planned to take place from 2019 onwards, within the investigations in line with find analysis from the ongoing excavations at the site of Svinjarička Čuka in southern Serbia.

The pilot study by Bogdana Milić and Barbara Horejs 'Modelling the Neolithic', based on the spread of the pressure technique and funded by the Dr. Anton Oelzelt-Newin'sche foundation yielded first results regarding the archaeological background and data collection strategies. The results were presented at the $24^{\text {th }}$ Annual meeting of the European Association of Archaeologists (EAA) in Barcelona in September this year, in the session concerning 'Modelling the Spread of Agriculture: The Application of Computational Modeling Techniques to the Neolithic Transition'.

Finally, an EAA session on the 'Strategies of obsidian procurement, knapping and use in the first farming societies from the Caucasus to the Mediterranean' was organised by Bogdana Milić and colleagues from the University of Sorbonne (Alice Vinet) and the French Ministry of Culture (Denis Guilbeau). As the outcome of the successful session, eleven papers with new approaches and results concerning the study of obsidian in relation to the Neolithic in this large area will be published in the edited volume by the session organisers within the internationally peer-reviewed OREA series.

\section{Diachronic studies in the Thessalian plain ( $6^{\text {th }}-3^{\text {rd }}$ mill. BC)}

The interdisciplinary stand-alone project Platia Magoula Zarkou: Cultural change during the $6^{\text {th }}$ millennium BC, funded by the FWF and directed by Eva Alram-Stern, was continued. The project Platia Magoula Zarkou aims at the analysis of the stratigraphy, use of space and a contextual presentation of the pottery and finds of this tell settlement, which is located in western Thessaly and dates to the Middle Neolithic as well as the Early Late Neolithic periods (6000$5300 \mathrm{BC})$.

In autumn 2018, a new core drilling with a depth of $62 \mathrm{~m}$ was conducted to reveal more data about the palaeogeographic setting of the site in collaboration with the University of Ferrara. Additionally, a raw material survey, directed by Michael Brandl (cf. Raw Material Lab) with the focus on the procurement of radiolarite, was performed to define the accessibility of this material (Fig. 41). It turned out that one major source was used which is about $40 \mathrm{~km}$ away from Platia Magoula Zarkou. Additionally, the publication process proceeded and the first volume should be submitted for publication in 2019.

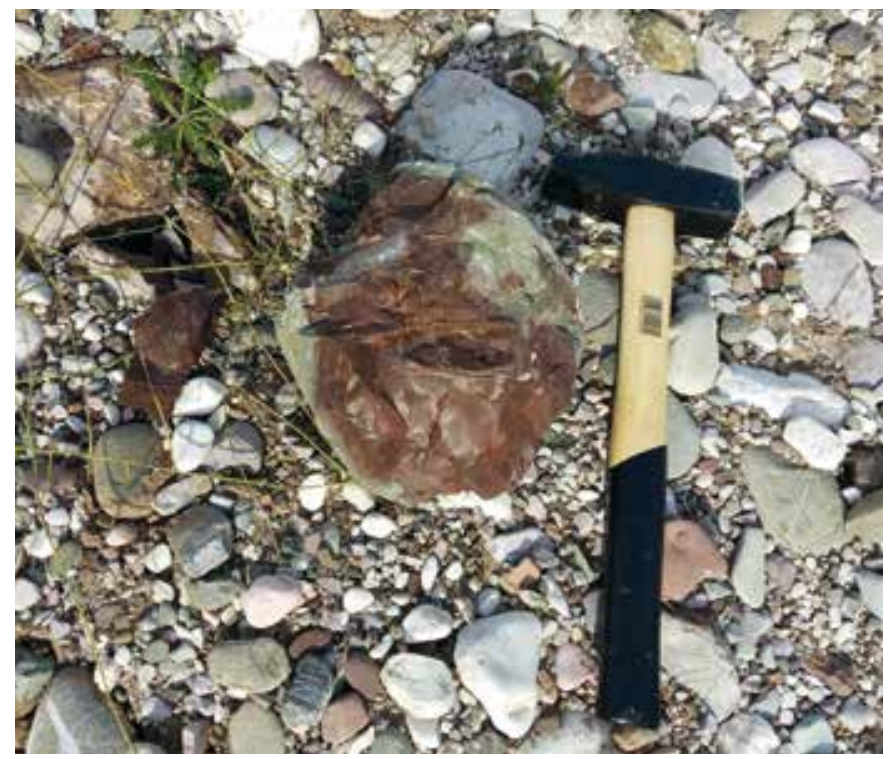

Fig. 41 High quality radiolarite nodule from gravels of the Portaikos river at Pili/Greece (photo: M. Brandl, C OREA) 
Chalcolithic and Early Bronze Age settlements, economies and technologies ( $4^{\text {th }}-3^{\text {rd }}$ mill. BC)

The studies on the $4^{\text {th }}$ and $3^{\text {rd }}$ millennia BC were extended from Greece to the United Arab Emirates focusing on settlement patterns and structures, economic background, sourcing, technological development and chronology. The aim is to reveal regionalisms as well as inter-regional communication and exchange networks during the Chalcolithic and Early Bronze Age sites in a vast geographic context.

Basic research on these questions has been conducted at Çukuriçi Höyük. During the twomonth research stay in the excavation house in Selçuk/Turkey, the focus was on the documentation of the pottery from phase ÇuHö IV and the corresponding small finds. A total of 2,047 characteristic and 10,758 wall fragments as well as 200 small finds were documented by Maria Röcklinger, thus completing the recording of the Early Bronze Age 1 pottery of Çukuriçi Höyük. The documentation of the ceramic material comprises the statistical recording of the entire material (significant pieces and wall fragments) as well as the detailed description (shape, type, variant, ware group, dimensions, etc.) of the characteristic vessel fragments. The records of the small finds were checked for completeness and new records were created for some of the objects. Working photos were taken of all small finds and data records were created in the database. This task was mainly carried out by Sabina Cveček, member of the DOC team 'The Role of Households at the Dawn of the Bronze Age'. In a final campaign, planned for 2019, all records will be checked again for completeness and final drawings and photos will be made.

In 2018, the second volume of the Çukuriçi Höyük series was released. The monograph of the dissertation by Christoph Schwall with a contribution by Barbara Horejs presents the results of Late Chalcolithic excavations at Çukuriçi Höyük embedded in a broad study of the $5^{\text {th }}$ and $4^{\text {th }}$ millennia in Western Anatolia and the East Aegean. Further volumes dealing with material studies of the site are in preparation.

Besides this volume, the proceedings of the conference 'Pottery Technologies and Sociocultural Connections between the Aegean and Anatolia During the $3^{\text {rd }}$ Millennium BC' edited by Eva Alram-Stern and Barbara Horejs was published. The main aim of this conference volume is to bring together archaeometric experts, and their scientific questions and data, with traditional archaeological pottery analysis. This enables broader archaeological and cultural contextualisation within one particular geographical area and time horizon - the Early Bronze Age 1-2 periods (3000-2300 BC) - on both sides of the Aegean. The results of two FWF-funded projects (managed by Eva Alram-Stern and Barbara Horejs) were published as several contributions within this volume as well.

The $\mathrm{PhD}$ thesis of Christopher Britsch concerning the technological studies of textile production tools has been successfully submitted. He included objects from Turkey, Greece and Bulgaria, covering a data set with more than 1000 items and evaluated these with different statistical analyses.

Besides the mentioned research, fieldwork was conducted in Lebanon and the United Arab Emirates. In the course of the excavations at Tell Mirhan in the Chekka region in the north of Lebanon (cf. research group Mediterranean Economies), preliminary work for a survey was performed with the help of airborne laser scanning (ALS) in the Chekka region and its hinterland. The planned survey aims to reveal data of the settlement pattern in the coastal region and the hinterland in a diachronic perspective. The Neolithic, Chalcolithic and Early Bronze Age periods in particular are focused on by Christoph Schwall.

Moreover, several visits by kind invitation of the Austrian Embassy to Abu Dhabi in the United Arab Emirates resulted in the pilot project 'Across Arabia' by Christoph Schwall in cooperation with the Archaeological Authority of the Emirate of Sharjah (SAA), which was approved by the Dr. Anton Oelzelt-Newin'sche Foundation (OeAW). Field investigations at the site of Kalba are starting in January 2019. The objective of this pilot study is, on the one hand, to obtain data on the geomorphology and the settlement dimensions with the help of geophysical analytical methods; on the other hand, a trial excavation should provide more detailed information on the Early Bronze Age and possibly earlier remains of the site. The aim is to assess the 


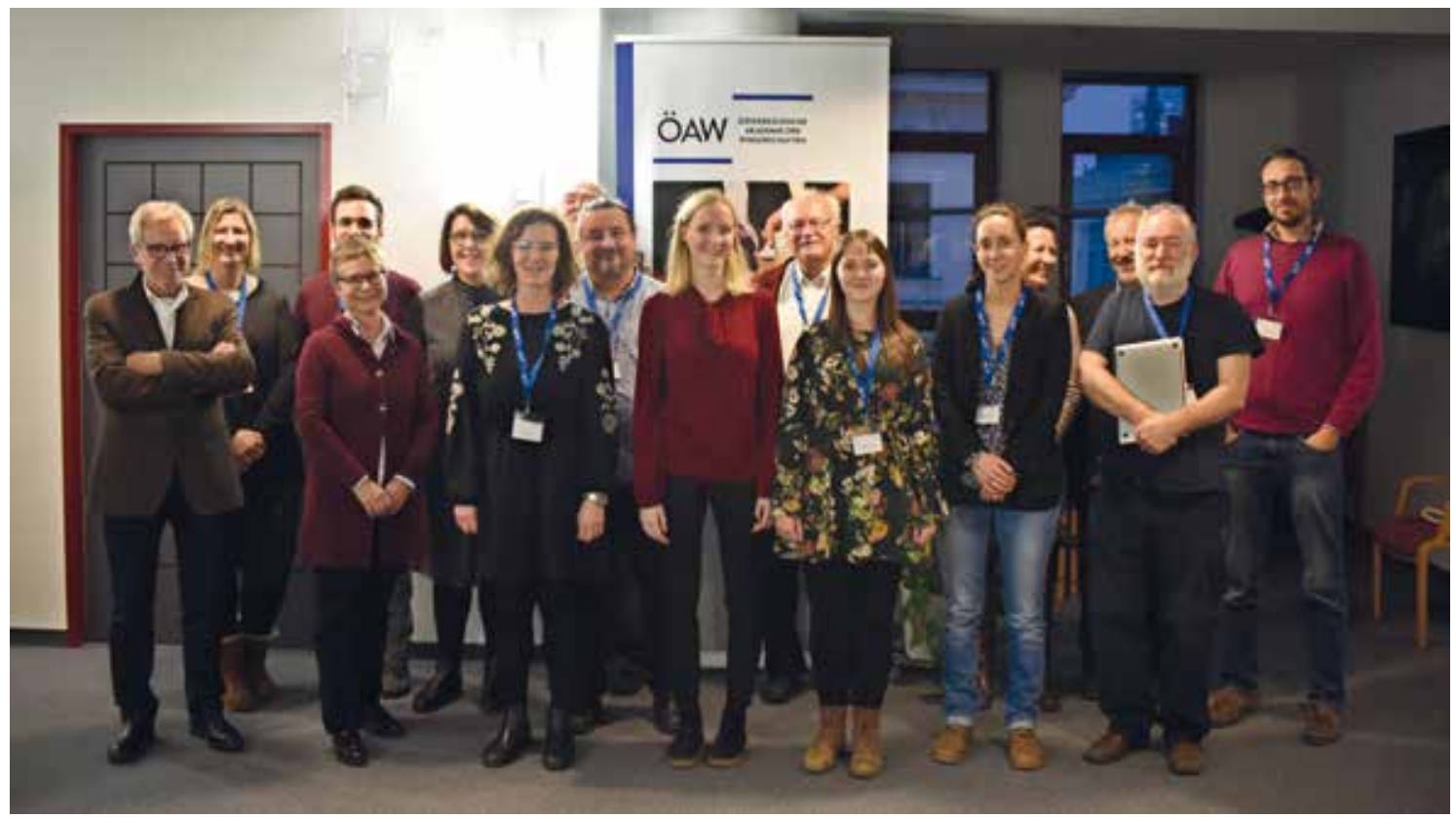

Fig. 42 Participants of the 'Household' Workshop held in October 2018 by the DOC-team (photo: F: Ostmann, (C) OREA)

settlement's function as well as its position on the Musandam peninsula and, moreover, within the extended framework of $3^{\text {rd }}$ millennium $\mathrm{BC}$ trading networks in the gulf region and beyond.

\section{The Role of Households at the Dawn of the Bronze Age}

Research in this jointly planned set of interdisciplinary dissertation projects focuses on studying households as a primary source for discussing the emergence of social structures in the Early Bronze Age ( $3^{\text {rd }}$ millennium BC), namely underlining the importance of bottom-up studies for classifying and studying prehistoric societies. Social equality or inequality are being addressed from a bottom-up perspective, by looking at the domestic organisation in which sharing becomes a leading trait for discussion of social organisation. The DOC team is an interdisciplinary $\mathrm{PhD}$ project on "The role of households at the dawn of the Bronze Age" and consists of four young researchers from the fields of social-anthropology, zooarchaeology and archaeology.

In the past year all four team members (Sabina Cveček, Stephanie Emra, Constanze Moser, Maria Röcklinger) participated in several group meetings, international workshops and conferences and in individual research stays abroad. Aside from individual stays abroad, this year the DOC team spent about two months together at the case site Çukuriçi Höyük in Turkey. In November 2018 an international workshop, organised by the $\mathrm{PhD}$ students, was held at OREA (Fig. 42). In this workshop, internationally known experts like Paul Halstead, Kostas Kotsakis and Ourania Kouka, as well as junior scholars from the three disciplines, presented their own case studies and contributed to the discussion of social organisation, household archaeology and the state of research in the Early Bronze Age Aegean and Western Anatolia. The workshop aimed to bring together specialists and young scientists working in the Aegean and Western Anatolia as well as experts on household archaeology in prehistory. The aim was to discuss concepts of social organisation, household archaeology and the state of research for the time and region in focus and to shed more light onto the social organisation of this nebulous period. In December, the team presented their current state of research at the $10^{\text {th }}$ DOC-Team Graduiertenkonferenz. 


\section{A new Approach for Golden Treasures}

During the second year of the Innovation Fund project 'A new Approach for Golden Treasures. Innovative Analyses in Archaeometry', samples from $3^{\text {rd }}$ millennium sites from Bulgaria, Greece and Turkey were analysed. Moreover, in cooperation with the National Archaeological Museum at Athens (NAM) a broad analysing series has been started. In a first stage of this analytical project, objects from several important sites dating to the Mycenaean period have been recorded and investigated using the portable laser ablation technique at Athens in May 2018. The analysation process by ICP-MS is currently in progress at the Curt-Engelhorn-Center for Archaeometry GmbH (CEZA). First preliminary research results of the archaeological and archaeometrical research have been presented in several lectures in Germany, Austria and the Czech Republic. Moreover, in the second half of the year further applications for the analyses of selected gold objects in Greece in spring 2019 have been submitted.

\section{Y-chromosomal Haplotypes in Prehistoric Horses}

Team: Gottfried Brem, Barbara Wallner, Simone Reiter, Sabine Felkel, Christoph Schwall (coordination of the archaeological part of the project)

The horse represents the domestic animal that most impacted human history; the domestication of the horse about 5500 years ago revolutionized transportation and the mobility of human societies, as well as warfare and agriculture. Horses, therefore, deeply influenced the politico-economic trajectory of human societies. Reciprocally, human activities have circled back on the recent evolution of the horse by creating hundreds of domestic breeds through selective breeding. Because they are closely associated with humans, horse remains can advance our understanding of history not only for horses but also for humans.

The group is leading the way in genetically exploring the origin of stallion lines in modern-day horses with strictly paternally inherited Y-chromosomal markers. So far, we see a strong influence from multiple stallions from the Middle East during the past 500 years in modern horses. In order

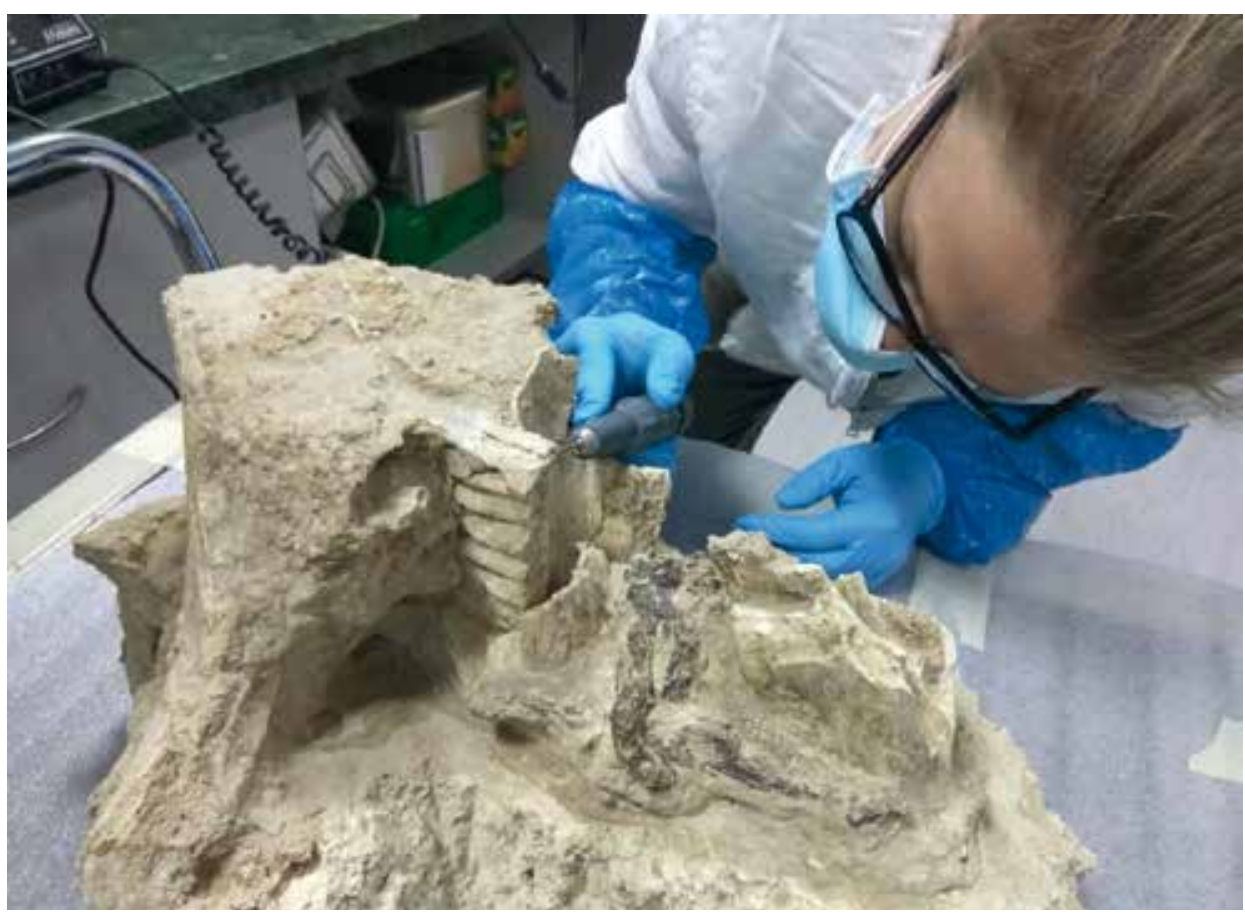

Fig. 43 Sampling of the 'Mleiha horse' in the Sharjah Archaeological Museum, UAE by S. Reiter (photo: A. Liebmann) 
to address what happened beyond this period we want to include the analysis of ancient DNA derived from museum samples. Such samples will recover a full time series of lineage frequencies and help us to better characterize historic demographic dynamics.

In 2018, the second year of the Innovation Fund project Y-chromosomal Haplotypes in Prehistoric Horses. To elucidate Domestication, Early Human and Land Settlement, Migration Waves and Warlike Operations, broad sampling series in various museums and collections in Austria, Croatia, Germany, Serbia, Slovenia and the United Arab Emirates have been conducted. The aim is to obtain samples from different periods to assess the development of horse domestication. A highlight within this approach was the sampling of the famous 'Mleiha horse', found at a grave in Mleiha in the Emirate of Sharjah (Fig. 43). This horse dates from between $150 \mathrm{BC}$ and $200 \mathrm{AD}$ and represents the oldest known horse on the Arabian Peninsula.

In autumn, analysis of the samples was started in the laboratories of the Natural History Museum Vienna (NHM) as well in Toulouse. The preliminary results of this research are expected in summer of 2019.

\section{Events}

- 21-22.11.2018: Workshop Household Archaeology in Old World prehistory - An Interdisciplinary Approach, organised by the DOC team fellows (M. Röcklinger, S. Cveček, St. Emra, C. Moser) of the Austrian Academy of Sciences.

- 18-19.10.2018: Workshop Pathways to the Late Neolithic of Central and Western Anatolia - The Case Studies of Çukuriçi Höyük and Çatalhöyük between 6500 and 6000 calBC, Initial workshop of scientific cooperation between Çatalhöyük and Çukuriçi Höyük teams, (B. Horejs).

- 8-12.9.2018: BE OPEN - Science and Society Festival, organised by the Austrian Research Fund FWF, Maria-Theresien-Platz, Vienna; curator of the Archaeology Pavilion: B. Horejs, organization: S. Pratsch (see above pp. 18-21 for more details).

\section{Outreach activities}

- 7.9.2018: Bogdana Milić organized together with Alice Vinet and Denis Guilbeau Session 335: Strategies of Obsidian procurement, knapping and use in the first farming societies from the Caucasus to the Mediterranean at the EAA 2018 in Barcelona.

- 6.11.2018: Barbara Horejs contributed to the panel discussion Club Research: Gesellschaftlicher Impact als politischer Auftrag. Woran muss sich Forschung heute messen? Vienna.

- 8.-12.9.2018: The research group organized (together with others) the Pop-up-Pavilion Archaeology: Was bringen 40.000 Jahre Migration? At the BE OPEN - Science and Society Festival, organized by the Austrian Research Fund FWF, Maria-Theresien-Platz, Vienna.

- 22.11.2018: Moritz Numrich and Christoph Schwall presented their Investigating on Golden 'Treasures': Mobile Laser Ablation ICP-MS Analyses on Bronze Age Gold Artefacts at a VERA seminar.

- Barbara Horejs presented her latest results on the Neolithisation in an interview with Der Standard: Die ersten Ackerbauern kamen über den Balkan nach Zentraleuropa https://mobil.derstandard.at/2000094258974/Die-ersten-Ackerbauern-kamen-ueber-den-Balkan-nach-Zentraleuropa?fbclid=IwAR2mSB75i5VFC83bWNoFtlJbgPMFTShilL8092ICRB7XuGr7Pp0vYxovvkE.

- ÖAW news: Barbara Horejs on "Das Wissen wandert immer mit den Menschen" zum 140 Jubiläum prähistorischer Forschung an der ÖAW https://www.oeaw.ac.at/detail/news/das-wissen-wandert-immer-mit-den-menschen/?fbclid=IwAR3-DVJm9DCcEDquEC15HMhNDzUY1mwl-HKE0ASfk3GZ_KENf2rWrG3TVUQ. 
Highlights 2018

- The OREA series volume "Çukuriçi Höyük 2. Das 5. und 4. Jahrtausend v. Chr. in Westanatolien und der Ostägäis" (Ch. Schwall with a contribution by B. Horejs) was published and is available open access.

- The OREA series volume "Pottery Technologies and Sociocultural Connections between the

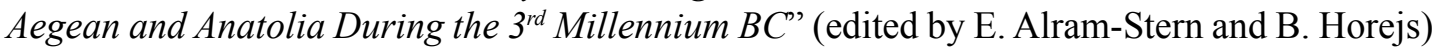
was published.

- Successful excavations at the newly detected site Svinjarička Čuka, Serbia during August and September 2018 in the course of the new 'Pusta Reka Project' by Barbara Horejs in collaboration with Aleksandar Bulatović (Archaeological Institute Belgrade) and the Museum of Leskovac in the Pusta Reka region near the city of Leskovac in southern Serbia. Coverage by local papers and TV stations guaranteed public awareness in the region and beyond.

Eva Alram-Stern - Barbara Horejs - Christoph Schwall - Gottfried Brem - Barbara Wallner 


\section{Prehistoric Identities \\ (Research group leader: Katharina Rebay-Salisbury)}

\section{Objectives}

The aim of the research group is to deepen our understanding of bioarchaeological methods and their diverse and complex scientific results, as well as to embark on a new, discursive path in identity research that discusses cultural and contextual information on an equal footing with bioarchaeological data.

Aspects of prehistoric identities - building blocks of how people saw themselves and others include age, sex and gender, descent, social relationships, ethnicity, status and religion. Many of these aspects are inextricably linked to the human body, the biological basis of existence through which the world is experienced.

Material culture is directly involved in the creation and maintenance of identities; it also serves to categorise people. Recording and interpreting artefacts, their spatial distribution and chronological development is one of the core competences of archaeology.

Increasingly, the analysis of human bones and teeth focuses on individual life histories of prehistoric persons, with the help of the latest scientific methods. Detailed anthropological analyses allow the reconstruction of biographies, including stress events and traumas, and form the basis for reconstructing health and nutrition. Examinations of human genetic material reveal relationship patterns, lineages and genetic origins. Isotope analyses provide valuable information about nutrition, mobility and migration.

Bioarchaeological data form the basis of the third science revolution in archaeology, which, in combination with established archaeological methods, is currently revolutionising research into prehistoric identities. The temporal and cultural depth as well as the archaeological context, however, now need to be reemphasised.

More than ever, a detailed examination of all aspects of identity, as they develop over time, intersect and influence each other, allows us to understand the human experience in prehistory, while at the same time allowing us to explore the archaeological record in a new light. The expertise developed will be employed by contributing to public and political debates on gender relations, origin and migration.

\section{Current research}

\section{The social status of motherhood in Bronze Age Europe}

\section{PI: Katharina Rebay-Salisbury, project members: Doris Pany-Kucera}

The research group Prehistoric Identities emerged from Katharina Rebay-Salisbury's ERC Starting Grant project 'VAMOS. The Value of Mothers to Society: responses to motherhood and child rearing practices in prehistoric Europe' (No. 676828), which examines how female identity changed through motherhood in the last three millennia BC. Its FWF-funded pilot project 'The social status of motherhood in Bronze Age Europe' (P 26820) was completed at the end of 2017. The project explored social responses to pregnancy, birth and early child rearing in Bronze Age central Europe and developed a methodological package for investigating motherhood through a combined theoretical and bioarchaeological approach. Methods included an assessment of the spatial distribution of the graves of infants, pregnant women, double burials of women and children; the gender and age analysis of material culture; the evaluation of status differences expressed through funerary treatment as well as in the quality and quantity of grave goods; osteological analyses (age at death, sex, body height, pathologies, with an emphasis on pelvic changes); ${ }^{14} \mathrm{C}$ dating; tooth cementum annulation; ${ }^{813} \mathrm{C} /{ }^{15} \mathrm{~N}$ isotope and aDNA analyses, as well as demographic modelling. Investigating the link between women's reproductive and social status included work on Early Bronze Age inhumation graves of groups with different burial practices from Lower Austria 
(Únětice and Unterwölbing); Middle and Late Bronze Age cemeteries also contained cremated individuals.

In early Bronze Age case studies, we found a young age for first time mothers in their late teens, and no particular differentiation between different kinds of women that could be explained by reproductive success. Age and gender were clearly the most important components of identity expressed in the funerary ritual. The typical age of first motherhood corresponds to high status values, which suggests a link between reproductive age and potential, but not necessarily reproductive success. The lifetime maternal mortality risk can be estimated at around $10-15 \%$, with women giving birth to between 7 and 8 children on average if they reached the age of menopause. We identified a shift in social organisation towards the Iron Age, which includes a higher age for marriage and motherhood as well as more diversity in women's lives, which may be linked to reproduction (Fig. 44).

\section{The Value of Mothers to Society: Responses to motherhood and child rearing practices in prehistoric Europe}

PI: Katharina Rebay-Salisbury; project members: Marlon Bas, Michaela Fritzl, Doris PanyKucera, Roderick B. Salisbury, Michaela Spannagl-Steiner, Lukas Waltenberger; project manager: Barbara Saringer-Bory

Research activities continued in the framework of 'VAMOS. The Value of Mothers to Society' in 2018. This ERC-funded diachronic study expands Katharina Rebay-Salisbury's research on motherhood both chronologically and thematically to write the history of motherhood over the last three millennia BC, from the late Neolithic to the late Iron Age (c. 3000-15 BC) through case studies in central Europe. With the aim of documenting and analysing social responses to pregnancy, birth and childrearing, the project focuses on the application of innovative archaeo-

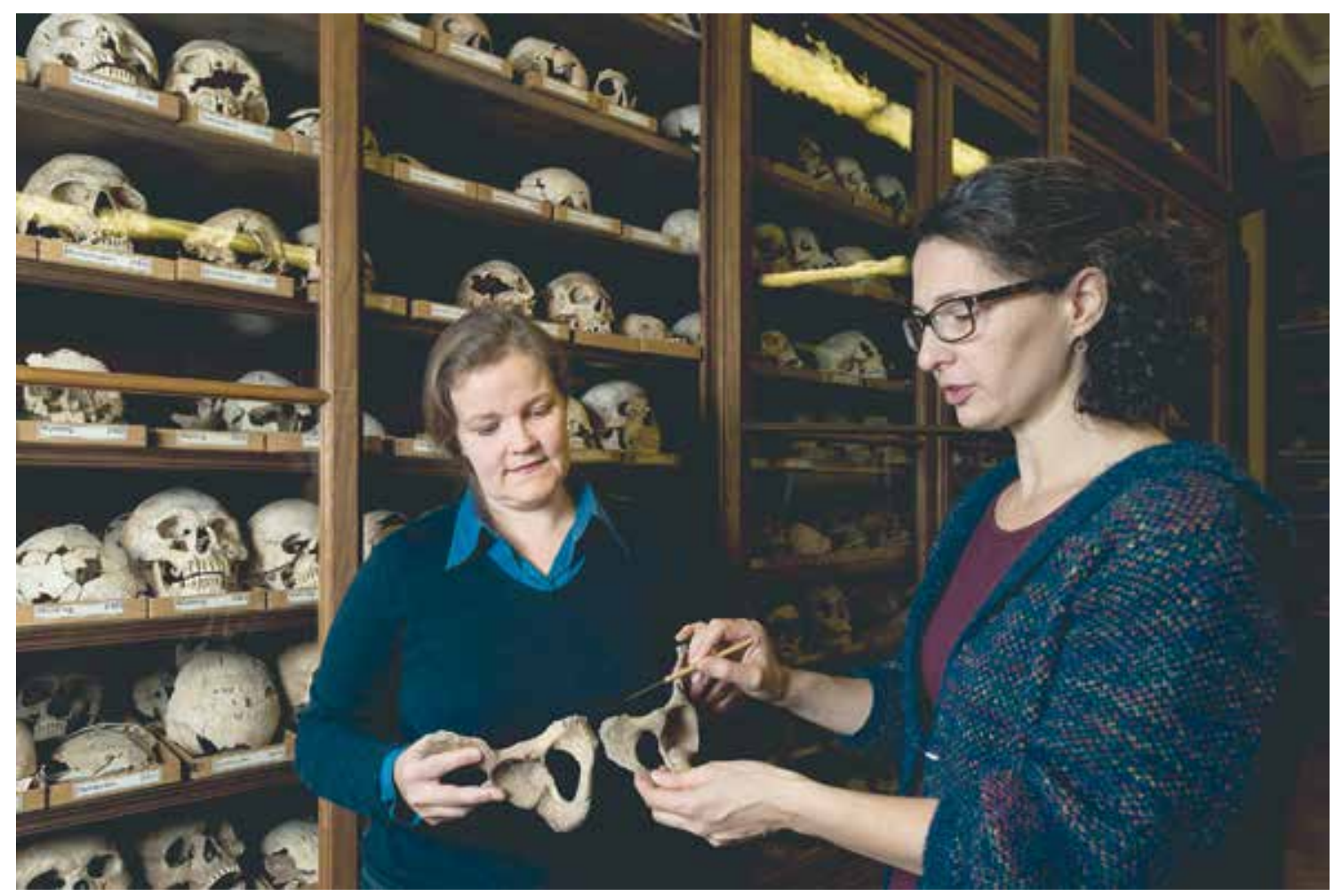

Fig. 44 Katharina Rebay-Salisbury and Doris Pany-Kucera discussing pelvic features at the Natural History Museum in Vienna (photo: L. Puiu, (C) OREA) 


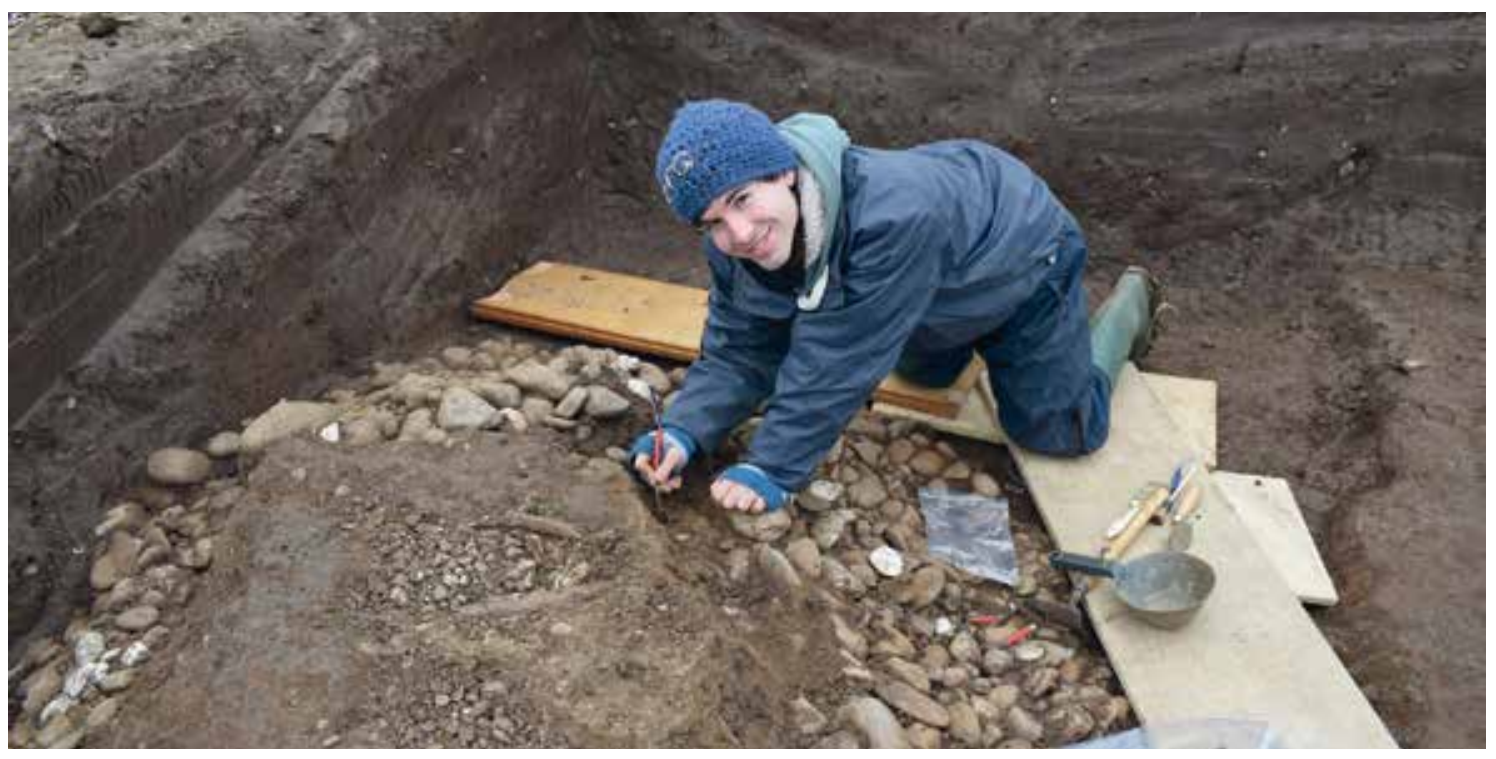

Fig. 45 Lukas Waltenberger excavating at the site Novo Selo, Bijeljina, Bosnia and Herzegovina (photo: M. Bas, C OREA)

logical and bioanthropological methods. Archaeological methods include the analysis of graves of infants, pregnant women, as well as double burials of women and children and a reconstruction of their social status. Anthropological methods include the palaeo-pathological reassessment of women's and infants' skeletons, tooth cementum analysis of selected individuals, isotope analyses to assess infant feeding practices and aDNA analyses to clarify genetic relationships between buried individuals and to determine the sex of infants. Through the juxtaposition of the status analysis of women's graves with documented physical changes in their bodies connected to pregnancy and birth, the link between reproduction and women's social status will be revealed.

Data acquisition, documentation and description of pelvic features and selected pathologies continued with Bronze Age skeletal series from Schleinbach, Franzhausen I, Zwingendorf and Pitten (all Lower Austria). The research strategy included sampling human remains for TCA, DNA, ${ }^{14} \mathrm{C}$ and $\mathrm{C}$ and $\mathrm{N}$ isotope analyses. Barbara Rendl has been appointed $(0.5 \mathrm{FTE}$ from 1.5.2018 to 30.4.2019) to work as a scientific/technical assistant. Her task is to produce histological thin sections of teeth and document tooth cementum annulation, providing age at death estimations. In a pilot study, she is currently assessing if TCA can be used to estimate the season of death.

Doris Pany-Kucera and Michaela Spannagl-Steiner's work on understanding pelvic features in relation to pregnancy and parturition continued. Collaborations with the anatomists Wolfgang Weninger and Barbara Maurer-Gesek from the Medical University of Vienna (Center for Anatomy and Cell Biology) and Stanislaus Argeny (Department of Surgery) aimed to clarify the origin of the newly described pelvic features 'preauricular extension' and 'preauricular notch'. Urogynecologist Engelbert Hanzal and radiologist Andrea Mair (AKH Vienna) facilitate access to clinical data for comparison. 3D data from the anatomical Weissbach Collection held at the Natural History Museum in Vienna will be integrated into the study of pelvic dimensions in collaboration with the Evolutionary Morphology Group Zürich (Martin Häusler and Victoria Krenn).

Three PhD projects are currently being carried out as part of VAMOS. Lukas Waltenberger's project 'Are parturition scars truly signs of birth? - A geometric morphometric approach to analyse pelvic birth marks' focuses on pelvic metrics and the digital documentation of pelvic features that might relate to pregnancy and birth (Fig. 45). Marlon Bas studies 'Macro and micro-wear in the developing juvenile dentition: diet and masticatory mechanics in past populations' to gain insights into the diet of children at our case study sites. Michaela Fritzl tackles 'Mobility, Migration and Connectivity at the Late Bronze Age cemetery of Inzersdorf ob der Traisen' using stron- 


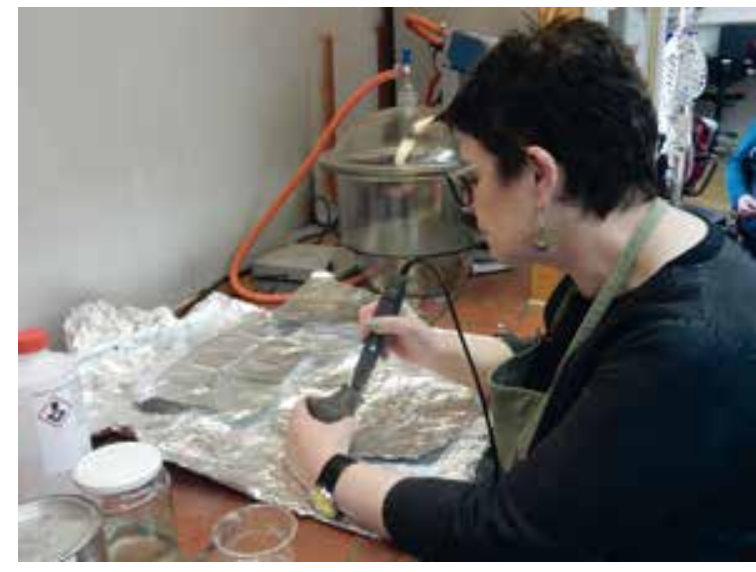

Fig. 46 Sampling feeding vessels at the Natural History Museum in Vienna with Julie Dunne (photo: K. RebaySalisbury, (C) OREA)

tium isotope analysis on cremated human remains. We have applied for funding from the FWF to expand this promising angle of research onto further Urnfield Culture cemeteries in the Traisen valley (Unlocking the secrets of cremated human remains: temporality, gendered mobility and family relations in Late Bronze Age Austria).

In collaboration with Julie Dunne and Richard Evershed from the Chemistry Department of the University of Bristol, we developed a minimally invasive strategy for sampling Bronze and Iron Age feeding vessels for molecules absorbed into the ceramics matrix. Chromatographic techniques, mass spectrometry and isotope mass spectrometry, are used to characterise the compounds. The aim was to find out if such vessels could be used for weaning, and which foodstuffs babies and small children were fed. Results indicate that a few of the prehistoric 'baby bottles' found in children's graves indeed contained ruminant animal milk, whereas others contained lipids from adipose animal fats from broths or stews (Fig. 46). Many were too contaminated to yield results, and some were likely deposited empty in the graves.

Funding: ERC Starting Grant Project 676828

\section{COPOWER: Government of Life and Death: The Rise of Coercive Power in European Late Prehistory}

\section{PI: Elisa Perego}

Elisa Perego's Marie Skłodowska-Curie Individual Fellowship CoPOWER: Government of Life and Death: The Rise of Coercive Power in European Late Prehistory (No. 750596, 1.7.2017 to 30.6.2019) adopts state-of-the-art archaeological and bioarchaeological approaches to investigate the transition to urban society, inequality, and the rise of social control mechanisms in Europe c. 2200-200 BC. Within this framework, a network of international collaborations on funerary archaeology, human-environment interaction, epigenetics, bioarchaeology, and burial taphonomy has been developed. Core collaborators on CoPOWER include Veronica Tamorri (London) on burial taphonomy and Rafael Scopacasa (UFMG and Exeter) on climate change. New collaborations include Claudio Cavazzuti (Rome/Durham), Marco Ferrante (Trace Research Centre), the Museo della Civiltà Romana in Rome and the Museo di Fratta Polesine in Veneto. Mobility and its relation to inequality have emerged as a key sub-theme of the project. The first CoPOWER case study has focused on displacement and mobility in southern Italy in the late first millennium BC. Research on climate change in Apulia has shown that potentially marginalised people moved into one of the most drought-prone areas of the Mediterranean in a period of temperature increase. This research, which has been published in Humanities, shows how the interplay between socio-political and environmental forces may have shaped the agency of subaltern groups on the move.

In the second CoPOWER case study, strontium isotope analysis has been carried out on a sample of abnormal burials from the late second-millennium BC production hub of Frattesina (Veneto, Italy). Oxygen and nitrogen-carbon isotope analysis will be carried out in 2019 to shed further light on diet and mobility in the same sample. Burial taphonomy and palaeopathology will provide additional data on burial rites, bone preservation and health. The applicability of aDNA analysis to the Frattesina sample is currently under investigation.

Funding: Marie Curie Grant 750596 
Events

- 17.12.2018, TAG Deva, Chester: \#SilentNightScience. Discussing the marginalisation of diverse voices in archaeological research (session organized by Elisa Perego).

- 13-14.12.2018, Vienna: Genes, Isotopes and Artefacts: how should we interpret the movements of people throughout Bronze Age Europe? (International Conference, organised by Claudio Cavazzuti, Benjamin Roberts and Katharina Rebay-Salisbury, supported by a 9,500€ Fritz Thyssen Foundation conference grant) (see above pp. 23-24 for more details).

- 20-22.9.2018, Vienna: $11^{\text {th }}$ Annual International Conference Society for the Study of Childhood in the Past (International Conference, organised by Katharina Rebay-Salisbury and Doris Pany-Kucera).

- 11.9.2018, Vienna: Disability in late Prehistory. Concepts, methods and Ethics (workshop organised by Elisa Perego).

- 23-24.5.2018, Vienna: Collapse and Inequality. Viewpoints from later prehistory (workshop organised by Elisa Perego).

\section{Outreach activities}

- VAMOS actively participated in three popular scientific events, offering a mini-workshop on sexing techniques in osteology to a broader, non-scientific audience:

- 28.9.2018: European Researcher's Night at the TGM, Vienna (5,800 visitors)

- 8-12.9.2018: BE OPEN - Science and Society Festival, organised by the Austrian Research Fund FWF, Maria-Theresien-Platz, Vienna (see above pp. 18-21 for more details)

- 13.4.2018: Lange Nacht der Forschung, Heldenplatz, Vienna (see above pp. 16-17 for more details)

- 18-19.8.2018: Archäologie am Berg, Hallstatt: Presentation of anthropological methods and scientific results of investigating skeletons from Hallstatt (Doris Pany-Kucera).

- An info-screen in the Anthropological Exhibition of the Natural History Museum in Vienna informs visitors about ongoing research on skeletal remains within the VAMOS framework.

- Katharina Rebay-Salisbury continued to run her research blog, with contributions by Marlon Bas and Michaela Fritzl: https://motherhoodinprehistory.wordpress.com/.

- Research blog articles appeared in Der Standard: Wie hat sich Mutterschaft auf das Leben urgeschichtlicher Frauen ausgewirkt? https://derstandard.at/2000071789616/Wie-hat-sichMutterschaft-auf-das-Leben-urgeschichtlicher-Frauen-ausgewirkt?_blogGroup=3 (Katharina Rebay-Salisbury), Alltag eines forensischen Anthropologen: Suche nach Vermissten des Zypern-Konflikts, https://derstandard.at/2000080702588/Alltag-eines-forensischen-Anthropologen-Die-Suche-nach-Vermissten-des-Zypern (Lukas Waltenberger).

- Doris Pany-Kucera presented her research on Hallstatt skeletons for several TV programmes ("Erde an Zukunft", "Lesch's Kosmos", "Terra mater Hallstatt").

\section{Highlights 2018}

- In collaboration with Julie Dunne from the University of Bristol, we used a combined molecular and isotopic examination of lipid residues in Bronze and Iron Age feeding vessels 
to understand what they might have contained. Results indicate that a few of the prehistoric 'baby bottles' from children's graves indeed contained ruminant animal milk. Other vessels were found to contain lipids from adipose animal fats pointing to broths or stews.

- The conference 'Genes, Isotopes and Artefacts: how should we interpret the movements of people throughout Bronze Age Europe?' organized by Claudio Cavazzuti, Benjamin Roberts and Katharina Rebay-Salisbury brought a large number of internationally renowned scholars to Vienna in December. New isotopic and genetic data on Bronze Age mobility was presented, and fruitful discussions emerged on how we may use them to understand Bronze Age societies in a new light.

- In September, Katharina Rebay-Salisbury and Doris Pany-Kucera hosted the $11^{\text {th }}$ Annual International Conference of the Society for the Study of Childhood in the Past at the Natural History Museum in Vienna. The conference theme 'Pregnancy, birth, early infancy and childhood: life's greatest transitions in the past' gave rise to an edited volume on bioanthropological and social stages of childhood, to which many of the conference participants agreed to contribute.

- Elisa Perego's engagement in marginality studies led to the submission of highly competitive grant proposals (ERC Starting Grant, Start Prize by the FWF) to expand her research on the theme of Disability in Prehistoric Europe.

Katharina Rebay-Salisbury - Doris Pany-Kucera - Roderick B. Salisbury Elisa Perego - Michaela Fritzl - Marlon Bas - Lukas Waltenberger 


\section{DEEPDEAD - Deploying the Dead: Artefacts and human bodies in socio-cultural transformations}

PI: Estella Weiss-Krejci; postdoctoral researcher: Sebastian Becker

\section{- Overall Objectives}

Long-dead bodies are pervasive and increasingly active participants in contemporary European society. Recent years have seen numerous examples of celebrated and sometimes controversial encounters with the dead, in Europe and beyond. In a number of European countries, calls for the exhumation and identification of victims of wars and civil conflicts are also becoming increasingly urgent. Even prehistoric bodies become emblematic of contemporary cultural values. Since the unquiet bodies of the dead are perceived as keys to unlocking fundamental social, religious, and literary questions, the HERA-JRP-III funded DEEPDEAD-project - a collaboration between archaeologists, literary scholars, and anthropologists in the UK, Austria, Germany, and the Czech Republic - attempts to map the links and differences between contemporary uses of the dead and comparable practices in past eras. In pursuit of this goal, project members are working within three main research areas: (1) Reuse of the prehistoric monuments; (2) Encounters with the longdead and their artefacts; and (3) Uses and agency of the dead.

- 2018 Activities of the Austrian DEEPDEAD-Team

Apart from the continued research in museum collections and archives (Fig. 47) as well the analysis of archaeological texts, in 2018 Estella Weiss-Krejci, Sebastian Becker, and Philip Schwyzer also finished a book proposal for an edited volume, which will be one of the major outcomes of the project.

\section{- Project Funding and Partners:}

HERA is a network of currently 26 national funding agencies committed to leading and developing funding opportunities for humanities researchers in Europe. The HERA JRP III UP, Joint Research Programme III, Uses of the Past; CRP 15.055 DEEPDEAD, which lasts from July 1, 2016-September 30, 2019 , has received $€ 1,160,116$ across four partners.

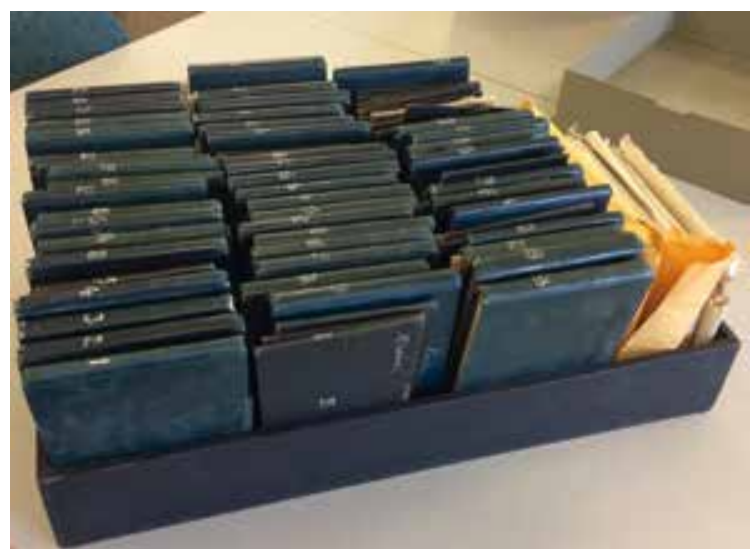

Fig. 47 J. Szombathy diaries (photo: E. Weiss-Krejci; courtesy Department of Prehistory, NHM, Vienna)

The international consortium partners are: Philip Schwyzer (PL and PI), Department of English, University of Exeter, United Kingdom; Estella Weiss-Krejci (PI), OREA, ÖAW, Austria; Andrew James Johnston (PI), Department of English, Freie Universität Berlin, Germany; and Ladislav Šmejda (PI), Czech University of Life Sciences Prague, Department of Ecology, Czech Republic. Associated partners are Harald Meller, Landesmuseum für Vorgeschichte, Halle/ Saale, Germany and Maria Teschler-Nicola, NHM, Vienna, Austria.

\section{- Conference Organisation and Lectures 2018}

The members of the Austrian DEEPDEAD team organised two international conferences, one session at an international meeting, and held several lectures.

'Beyond Death: Exploring the uses of dead bodies, funerary objects, and burial spaces through time,' was organised by Estella Weiss-Krejci and Sebastian Becker and held at the Austrian Academy of Sciences from 2-4 May, 2018. It explored the uses and meanings of dead bodies, objects, and burial spaces over long periods of time. Contributions came from the fields of archaeology, literary studies, social and physical anthropology, and history. Estella Weiss-Krejci presented the Introduction on 3 May and on 4 May Sebastian Becker and Estella Weiss-Krejci contributed a paper with the title: Reading between the bodies: archaeological writing and memory work.

The conference 'Tote Körper zwischen Nutzen und öffentlichem Ärgernis: Ethische, politische, kulturelle Überlegungen zum Umgang mit menschlichen Überresten' (7-8 November 2018) was co-organised by Estella Weiss-Krejci together with Claudia Augustat from the Weltmuseum Wien, 
and Igor Eberhard from the Department of Cultural and Social Anthropology of the University of Vienna. The keynote lecture was held at the Department of Cultural and Social Anthropology; the rest of the conference took place in the Weltmuseum Wien. This conference brought together a group of German-speaking physicians, cultural anthropologists, restorers, archaeologists, anthropologists, culture managers, and taxidermists and addressed the ethical, political, and museological dimensions of human remains. The introductory notes Steine des Anstoßes: Einleitung zum Workshop were delivered on 8 November by Claudia Augustat, Igor Eberhard, and Estella Weiss-Krejci.

On 8 September, 2018 Estella Weiss-Krejci, Sebastian Becker, and Ladislav Šmejda organised a half-day session at the $24^{\text {th }}$ Meeting of the European Association of Archaeologists (EAA), 5-8 September, in Barcelona. Session 305: 'Deploying the Dead II: Dead Bodies and Social Transformations', which included an Introduction by the organisers; a paper by Sebastian Becker, Estella Weiss-Krejci, Kirsten Mandl, and Maria Teschler-Nicola titled: Threaded ancestors: the use of (human) bone ornaments in Early Bronze Austria; and a paper by Estella Weiss-Krejci: One dynasty, two countries: the divergent fates of two collective Habsburg tombs.

Estella Weiss-Krejci presented the lecture Die Toten der Vergangenheit und ihr Gebrauch: Einblicke in das DEEPDEAD-Projekt on 21 March, 2018 at the OREA Institute in Vienna and on 29 November, 2018, in Graz, Austria at the Forum Anthropologie Steiermark 2018 ,Skelette, Knochen, Mumien ... - Menschliche Relikte in Museen und Ausstellungen.

\section{- Supervision and Teaching}

In 2018 Estella Weiss-Krejci started to supervise two new master's theses and two dissertations; was appointed member of the dissertation committee of Hemmamuthe Goudiaby (Dissertation title: Pratiques funéraires et statut des morts dans les ensembles résidentiels mayas classiques (205-950 apr. J.-C., completed 14 February, 2018), Université Paris 1 Panthéon-Sorbonne; finished the semester course 'Interdisziplinarität in der Sozialanthropologie' (WS 2017/2018) with Khaled Hakami at the Department of Social and Cultural Anthropology, University of Vienna; and taught one course in the seminar 'Les pratiques mortuaires sont-elles un processus technique comme les autres?' at the Université Paris 1 Panthéon-Sorbonne on 28 March, 2018 titled Exhibition, museology and repatriation of human remains. On 12 December, 2018 together with Hans Reschreiter, Ilja Stefflbauer, and Khaled Hakami she gave a tour for students through the exhibition 'Krieg: Auf den Spuren einer Evolution' at the NHM, Vienna.

\section{Outreach activities}

- 18.6.2018: Estella Weiss-Krejci, Die Herzbestattung als politisches Instrument vom Mittelalter bis zur Neuzeit, a lecture within the framework of the public lecture series 'Die Macht der Toten: Geschichte, Politik, Literatur' (Der Offene Hörsaal der Freien Universität Berlin: Interdisziplinäre Ringvorlesungen für die breite Öffentlichkeit), which was organised by the DEEPDEAD-team of the Free University of Berlin.

- Articles about the DEEPDEAD project related initiatives and research appeared in Die Presse (5 May, 2018, p. 32), Der Standard (31-1 November, 2018, p. F8), The Toronto Star (13 August, 2018), and on the ÖAW homepage. Project information and illustrations were included in the German ARD TV-show 'W wie Wissen: Die neue Bestattungskultur/"Ökobestattung": Nachhaltige Särge und Urnen' on 24 November 2018.

- The ethics of using dead bodies in museum collections for research and display were discussed in the conference 'Tote Körper zwischen Nutzen und öffentlichem Ärgernis: Ethische, politische, kulturelle Überlegungen zum Umgang mit menschlichen Überresten' held at the Weltmuseum Vienna 7-8.11.2018 (organized by Estella Weiss-Krejci - OREA, Claudia Augustat - Weltmuseum Wien, Igor Eberhard - Department of Cultural and Social Anthropology of the University of Vienna). 


\section{LEVANTINe AND EgYPTIAN Histories}

(Research group leaders: Roman Gundacker \& Felix Höflmayer)

\section{Objectives}

Near Eastern Studies, Biblical Archaeology, and Egyptology have developed individual approaches and specific traditions for addressing the historical questions and specific problems of the pre-classical period of the wider Near East. The OREA Institute is one of the few international research institutions that has developed a multidisciplinary focus on and an integrative approach to the history and archaeology of Egypt and the Levant. The research group Levantine and Egyptian Histories aims at consolidating and expanding this internationally unique research profile and continues to stimulate and advance the cooperation between Egyptology, Biblical Archaeology, and Near Eastern Studies via a combination of philology and archaeology. On the one hand, textual sources from Egypt and the Levant and, on the other hand, the material culture unearthed by the archaeological disciplines are considered as vital sources of equal importance.

'Levantine and Egyptian Histories' focuses on the Chalcolithic, Bronze, and Iron Ages (c. 5000-600 BC) in the region of the Nile Valley, the eastern Mediterranean littoral and its hinterland up to the Syrian and Jordanian deserts. 'Levantine and Egyptian Histories' explores the history and archaeology of these lands, as well as transregional phenomena such as trade and exchange, migration and identity, cultural transfer, adaptation, and adoption as well as language contact and development. While current projects mainly focus on the chronology, history, culture, and interregional contacts of the Bronze Ages, 'Levantine and Egyptian Histories' also aims at developing new projects including the Iron Age.

The long-term aim of 'Levantine and Egyptian Histories' is to provide a firm basis for overarching research questions that lead to the historical synthesis of Egyptian-Levantine interconnections based on the evaluation of philological and archaeological data in concord with a radiocarbon-backed chronological framework, all contributing as equal sources.

\section{Current research \\ 'Challenging Time(s)' \\ A New Approach to Written Sources for Ancient Egyptian Chronology}

PI: Roman Gundacker, project staff: Annik Wüthrich, Hermine Huber (project management)

This research project works on the systematic re-assessment of written sources which represent a corner stone for Egypt's historical chronology. Among the written sources, the king lists are of significant influence even today. For example, the periodisation of Egyptian history and its division into 31 dynasties are based on the king list of Manetho, an Egyptian priest and historian (c. $280 \mathrm{BC}$ ) writing for the Ptolemaic kings in Greek. It is thus surprising that there has never been an in-depth analysis of the royal names found in Manetho's king list and in the works of further Greek historiographers (Herodotus, Diodorus of Sicily, Pseudo-Apollodorus/PseudoEratosthenes, so-called 'Leipziger Weltchronik' and dispersed mentions of Egyptian royal names in Greek and Latin sources, e.g., Pliny the Younger). Also, the relationship between those Greek king lists and their Egyptian precursors (Royal Canon of Turin, King Lists of Abydos, Saqqara, Abusir, Table of Kings at Thebes, sequence of kings in Papyrus Westcar) and the ample contemporaneous written evidence of the various periods of Egyptian history is unclear.

'Challenging Time(s)' advances the current understanding of written sources and the methods of evaluation by (1) systematically examining royal names on a linguistic basis, which includes re-vocalisation and morphological analysis in the light of recent onomastic research; (2) compiling dated inscriptions and testing the currently proposed attribution to certain kings in a broader context if no royal name is given as part of the date or the further inscription; (3) testing chronological schemes on the basis of prosopographic data which is used for establishing genealogies of royalty and commoners and sequences of officials; (4) combining the results of the three research 
objectives just mentioned in order to define Egypt's historical chronology more precisely. The primary aim of 'Challenging Time(s)' is to test established theories and to get new information from written sources in order to advance further the rigour and accuracy of ancient Egyptian historical chronology, which is a highly important reference point for the chronological systems of neighbouring Near Eastern and Mediterranean cultures and for the calibration and statistical evaluation of radiocarbon dates.

In June 2018, Annik Wüthrich joined the team of 'Challenging Time(s), primarily concentrating on the collection, translation and analysis of the written sources of the $21^{\text {st }}$ Dynasty as part of her sub-project on the Third Intermediate Period. The written documentation is crucial for the reconstruction of the structure of society both in Thebes and Tanis/Memphis, the two centres of power, and for determining the connections between them. Besides the factual reconstruction of the historical chronology of this period, this study aims at establishing the genealogical tree of the reigning families in interconnection with the members of the elite. Special attention has been paid to the expressions of filiation during this period in order to see whether or not their variety has specific implications on an ideological or societal level. A part of these results will be presented at an international congress on the Third Intermediate Period in Grenoble (France) early next year. Over the coming years, this approach will be extended to the subsequent dynasties in order to see the evolution of the expression of the lineage. In parallel, the collection of dated inscriptions and their attribution to kings, the re-construction of non-royal lineages and the identification of sequences of local rulers and officials will be advanced.

Research on Manetho and his king list has started with the troublesome evaluation of testimonia. It is paramount to re-assess the chronological and geographical whereabouts of Manetho himself in order to determine his background and the context in which he composed his Egyptian

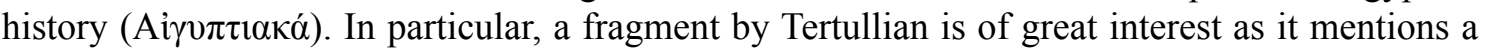
number of historians who may have been recipients of Manetho, Berossos and Hieromos of Tyre. Further research will most likely help to define Manetho's floruit, which is commonly dated to the $3^{\text {rd }}$ century $\mathrm{BC}$, but recently was said to be searched for in the $1^{\text {st }}$ century $\mathrm{BC} / \mathrm{AD}$. The entire state of affairs is highly complicated and will require more time and resources, but a critical reassessment of allegedly secure interpretations and of certain crucial testimonia will definitively produce a sound result concerning Manetho's floruit.

The evaluation of royal names has concentrated on the $5^{\text {th }}$ Dynasty, which is poorly preserved in the Greek king lists. Furthermore, the $5^{\text {th }}$ Dynasty is a stumbling block insofar as the, in part, folkloristic topic of the Heliopolitan princes, as reflected in the stories of Papyrus Westcar, makes one expect a vivid entanglement of history and literary reception. A paper presented at the conference on Old Kingdom Art and Archaeology in Warsaw (2014) was thus re-worked and augmented on the eve of printing (with sincere thanks to Kamil Kuraszkiewicz, who made this possible). For the time of the $4^{\text {th }}$ Dynasty, a key scene for the reconstruction of the royal family's genealogy was examined in great detail, with the result that the hitherto accepted reconstruction is not in line with the material remains and the cultural and societal background. Three relief fragments (Fig. 48) found in the 1920s near or in mastabah G 7110/20 in Gizah, which are usually attributed to a single genealogical scene illustrating the descent of Prince Kawab from Queen Meretites I and Cheops, must, in fact, be assigned to two different genealogical scenes. One of these records Queen Meretites I and Cheops as the parents of Princess Hetepheres (the wife of Prince Kawab and, after his death, as Queen Hetepheres II, the wife of Redjedef); the other, which remains highly con-
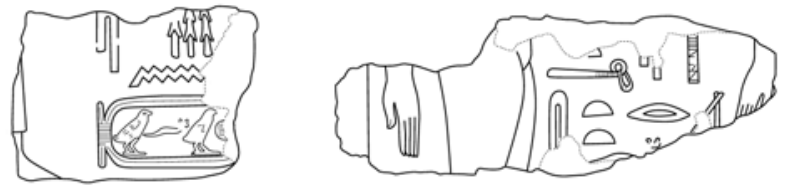

Fig. 48 Fragments of two genealogical scenes of Kawab and Hetepheres [II] (drawing: Liza Majerus) jectural, names Prince Kawab as the son of Queen Hetepheres I, a queen of Sneferu and the mother of Cheops (Fig. 49). The impact of this revised reconstruction on the overall assessment of the royal lineage of the $4^{\text {th }}$ Dynasty and its further effects on the de- 

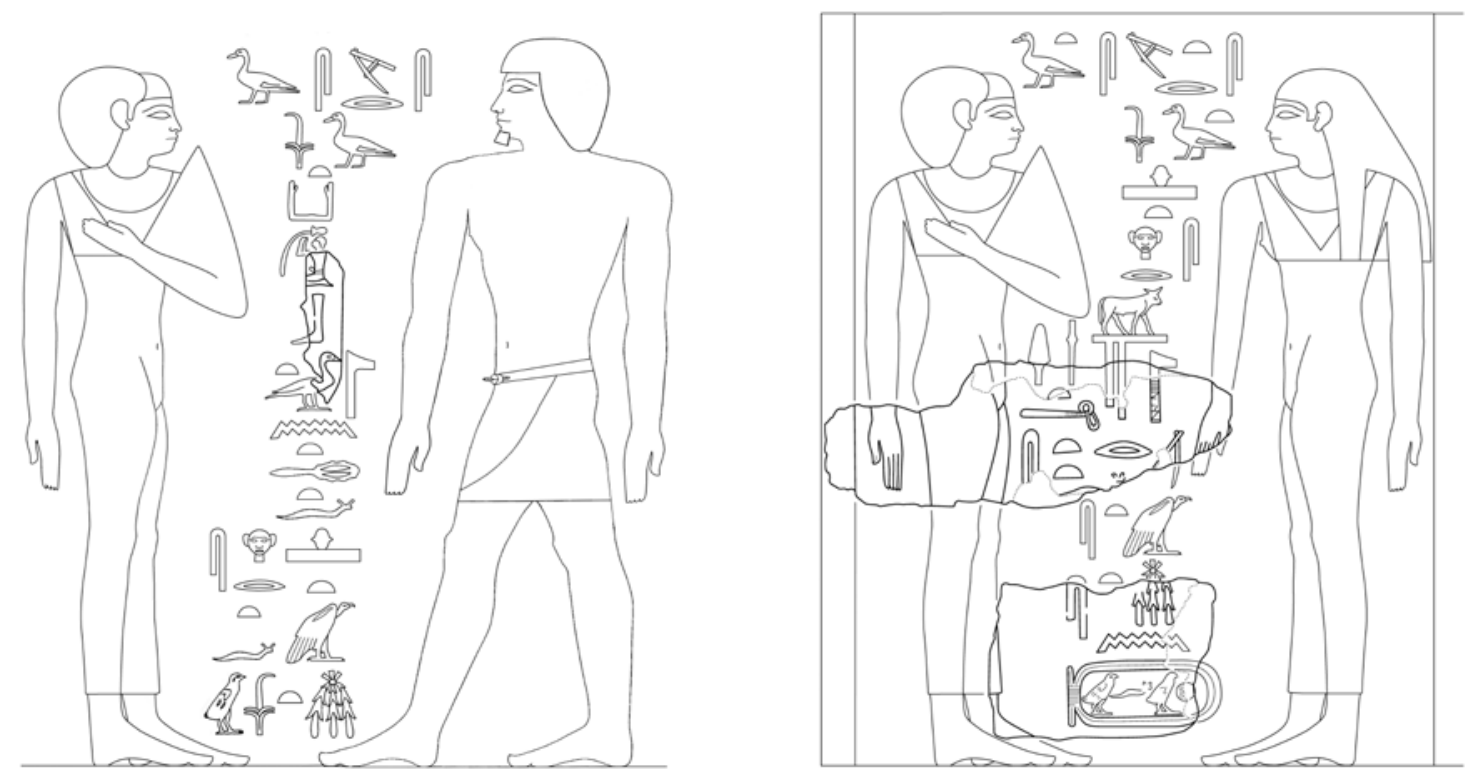

Fig. 49 Kawab and his mother, Queen Hetepheres I (left), Hetepheres [II] and her mother, Queen Meretites I (right), (drawings: Roman Gundacker, Liza Majerus)

termination of the regularity of the ideally biannual census, which is crucial for the entire system of dating and time reckoning during the Old Kingdom, cannot be predicted at the moment.

Funding: ERC Starting Grant (Grant Agreement Number 757951, European Research Council)

Cooperations: Julia Budka (Ludwig Maximilan University, Munich), Georg Danek (University of Vienna), Günter Dreyer (German Archaeological Institute, Cairo office), Armenuhi Drost-Abgarjan (Martin-Luther-University, HalleWittenberg), Heiner Eichner (University of Vienna), Peter Jánosi (University of Vienna), E. Christiana Köhler (University of Vienna), Nadine Moeller (The Oriental Institute, University of Chicago), Thomas Schneider (University of Vancouver), Stéphane Polis (University of Liège)

\section{Egyptian-Levantine Relations in the $4^{\text {th }}$ and $3^{\text {rd }}$ Millennia $B C$}

\section{PI: Felix Höflmayer}

This project reassesses the relations between the Levant and the Nile Valley based on the new radiocarbon-backed high Early Bronze Age chronology. This period encompasses state formation processes in Egypt during the Proto- and Early Dynastic Period, the Old Kingdom, and its collapse at the end of the $6^{\text {th }}$ Dynasty. The Levant saw the so-called Egyptian 'colonies' at the beginning of the Early Bronze Age, the rise of urbanism during Early Bronze II and III, its collapse, and the advent of the de-urbanized Early Bronze IV (or Intermediate Bronze Age). In 2018, Felix Höflmayer co-organized a workshop on "Transitions during the Early Bronze Age in the Levant. Methodological Problems and Interpretative Perspectives" together with Matthew J. Adams and Valentine Roux that took place at the W. F. Albright Institute of Archaeological Research and the Centre de recherche français à Jérusalem.

Funding: APART Fellowship of the Austrian Academy of Sciences (until April 2017)

Tracing Transformations in the Southern Levant:

From collapse to consolidation in the mid-second millennium $B C$

PI: Felix Höflmayer, project staff: Katharina Streit (Hebrew University of Jerusalem), Lyndelle Webster (OREA), Vanessa Becker (University of Vienna)

This project is being conducted in close cooperation with the University of Vienna and Hebrew University of Jerusalem and explores the history and archaeology of the late Middle and early Late 


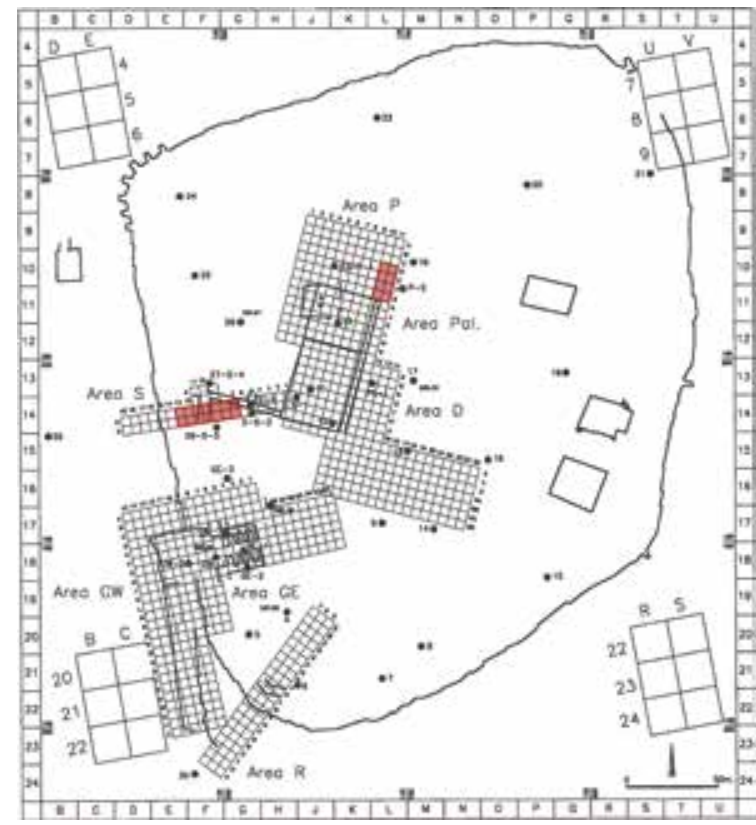

Fig. 50 Map of Tel Lachish with current excavation areas highlighted in red (grafics: F. Höflmayer based on Ussishkin 2004)

Bronze Age in the southern Levant. This period saw the demise of the Middle Bronze Age city-states, the end of the Hyksos Empire in Egypt, and the rising interest and involvement of the Pharaohs in the Levant, culminating in the military campaigns of the Thutmosid period and leading to the 'International Age' of the Late Bronze Age Amarna period. This transformative period is still poorly understood due to an insecure chronological framework, with many open questions regarding the chronological synchronization of Egypt and the Levant. So far, assessments of this period were dominated by a text-based approach relying heavily on Egyptian sources, while archaeological data from the southern Levant was not always fully appreciated.

'Tracing transformations' sheds new light on this formative period by (1) a targeted excavation of late Middle and early Late Bronze Age settlement layers at Tel Lachish; (2) establishing an absolute chronology for the late Middle and early Late Bronze Age based on sequences of radiocarbon dates that can be correlated with the radiocarbon-backed New Kingdom chronology of Egypt; (3) an in-depth study of the value of Egyptian scarabs seals for chronological purposes; (4) a comprehensive study of the development of material culture of the southern Levant based on the radiocarbon chronology, and (5) a new historical assessment of the period based on the new chronological framework, the results of the study on material culture, and a critical study of the available text sources.

In July/August 2018, the second season of excavation was conducted at Tel Lachish. Work continued in Area $\mathrm{S}$ on the western side of the mound and a second area (Area P) was opened north of the Judean palace/fort in order to trace the continuation of the Middle Bronze Age palace that was partly excavated by the Tel Aviv University Expedition under David Ussishkin (Fig. 50). In Area S, we continued to excavate settlement contexts of the early Late Bronze Age outside a sub-

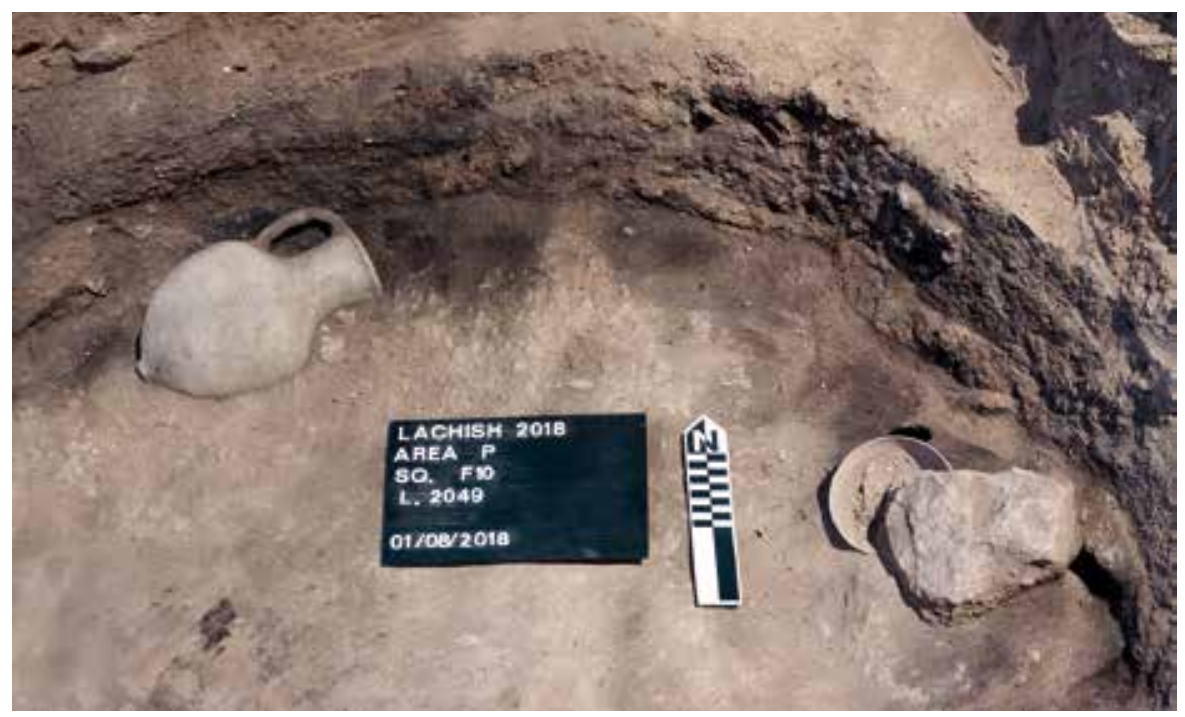

Fig. 51 Late Bronze Age offering pit (?) with complete vessels in situ (photo: J. Dye) 
stantial building (Strata S-3a/b and S-4). Notable finds include a scarab of the "Carnelian and Red Jasper scarabs with cross design" group, significant amounts of Cypriot White Slip and Base Ring pottery, and a Proto-Canaanite inscription. In Area $P$, the eastern continuation of the Middle Bronze Age palace was found. Walls were built of well-laid mud-bricks, coated with white plaster. Further, a Late Bronze Age offering pit (?) cutting into the walls of the palace was found that included a significant number of beads and shells, complete vessels and an almost completely preserved Mycenaean straight-sided alabastron (Fig. 51). Later, Area $\mathrm{P}$ was used for domestic purposes, several walls of the late Late Bronze Age and early Iron Age were discovered, including an almost complete Late Bronze Age chalice (Fig. 52).

First results of the Austrian-Israeli excavations were presented by Felix Höflmayer and Katharina Streit in Vienna; at an event sponsored by OREA at the W.F. Albright Institute in Jerusalem; at the Annual Meeting of the American Schools of Oriental Research in Denver,

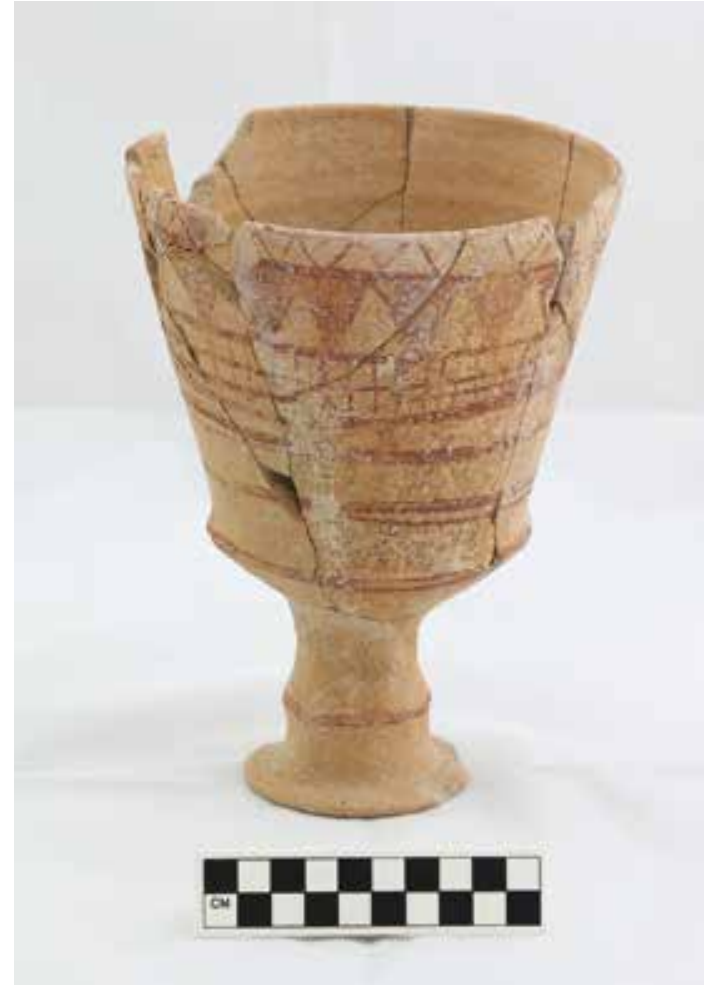

Fig. 52 Late Bronze Age chalice (photo: J. Dye) $\mathrm{CO}$, and at the Wissenschaftliches Kolloquium des Deutschen Palästina-Vereins in Mainz. A first preliminary report appeared in December 2018 in the journal Near Eastern Archaeology.

Additional results of individual sub-projects were presented by Lyndelle Webster, Vanessa Becker, Katharina Streit and Felix Höflmayer at various international conferences, such as the $11^{\text {th }}$ International Conference on Archaeology of the Ancient Near East (ICAANE) in Munich in April 2018; the 23 ${ }^{\text {rd }}$ International Radiocarbon Conference in Trondheim in June 2018; the $3^{\text {rd }}$ Crossroads conference in Prague in September 2018; and the Annual Meeting of the American Schools of Oriental Research in Denver, CO in November 2018.

Funding: FWF START Y-932

Cooperations: Israel Antiquities Authority, Israel Nature and Parks Authority, Prof. Ilan Sharon (Hebrew University of Jerusalem), Dr. Matthew Adams (W.F. Albright Institute of Archaeological Research, Jerusalem), Prof. Dr. Jens Kamlah, PD Dr. Simone Riehl (University of Tübingen), Prof. Dr. Michael W. Dee (University of Groningen)

\section{Untersuchungen zur Nominalkomposition des Ägyptischen}

\section{PI: Roman Gundacker}

The main objective of this research project is to identify and analyse compound nouns as found in ancient Egyptian. This requires the meticulous evaluation of hieroglyphic, hieratic and demotic writings of potential compound nouns and the search for offspring in Coptic or Egyptian Arabic and for vocalised renderings in cuneiform, Hebrew, Aramaic, Greek, Meroitic and Old Nubian texts. It is paramount to distinguish between morphological compounds (traditionally called 'Ältere Komposita') and syntactical compounds or juxtaposita (traditionally called 'Jüngere Komposita'). Beyond linguistic aspects, the evaluation of compound nouns ('Ältere Komposita'), which were only created until the breakdown of the Old Kingdom (late third millennium BC) and many of which denote key concepts of Egyptian elite culture, contributes to the determination of the Egyptians' mindset at the dawn of Egyptian civilisation in the fourth and third millennium BC. 
In 2018, three papers which communicate preliminary, though essential, results from the research on morphological compounds ('Ältere Komposita') were published. They deal 1) with the geographical distribution of morphological compounds ('Ältere Komposita') and their importance for drafting a dialectal map of Old Egyptian (third millennium BC), 2) with the gradual replacement of morphological compounds ('Ältere Komposita'), the causes for this process, the mechanisms applied and the general cultural background thereof, and 3) with the significance of morphological compounds ('Ältere Komposita') for the grammatical and metrical evaluation of texts (in this case: Pyramid Texts). Further publications are on the way, in particular the proceedings of the workshop Componendo composito, which is currently being prepared.

Funding: APART Fellowship of the Austrian Academy of Sciences (until December 2017)

Cooperations: Research Project "Strukturen und Transformationen des Wortschatzes der ägyptischen Sprache. Text- und Wissenskultur im alten Ägypten" of the Berlin-Brandenburg Academy of Sciences (directed by Tonio S. Richter); Chicago Demotic Dictionary of the Center for Near Eastern Languages and the Oriental Institute of the University of Chicago (directed by Janet H. Johnson)

\section{Events}

- F. Höflmayer - M. J. Adams - V. Roux, Transitions during the Early Bronze Age in the Levant. Methodological Problems and Interpretative Perspectives, W. F. Albright Institute of Archaeological Research and Centre de recherche français à Jérusalem, Jerusalem, May 2018.

- A. Wüthrich (co-organiser), 50. Ständige Ägyptologenkonferenz: Kulturen im Kontakt. Altägypten und seine Nachbarn, Institut für Ägyptologie und Koptologie, Westfälische Wilhelms-Universität Münster, Münster, July 2018.

\section{Outreach activities}

- 8-12.9.2018: Tracing Transformations was featured in the Archaeology Pavilion at the BE OPEN - Science and Society Festival, organised by the Austrian Research Fund FWF, Maria-Theresien-Platz, Vienna (see above pp. 18-21 for more details).

- Felix Höflmayer was interviewed in the Austrian newspaper Die Presse (published $9^{\text {th }}$ November 2018, title 'Neue Befunde bringen der Archäologie neue Rätsel').

- Roman Gundacker was interviewed for the series 'Junge Forschung' in the renowned Austrian News Paper Die Presse (published $21^{\text {st }}$ April 2018, title "Pharaonennamen in neuem Licht)".

\section{Highlights 2018}

- Second season of excavation at Tel Lachish directed by Felix Höflmayer and Katharina Streit.

- Start of the ERC Starting Grant 'Challenging Time(s)'-A New Approach to Written Sources for Ancient Egyptian Chronology directed by Roman Gundacker (Principal Investigator).

- Felix Höflmayer was part of the delegation of Federal Minister Heinz Faßmann and Federal Chancellor Sebastian Kurz on their visit to Israel in June 2018. 


\section{Material Culture in Egypt and Nubia \\ (Research group leader: Bettina Bader)}

\section{Objectives}

The lucky combination of Egypt being an early literate society with a rich artistic legacy on the one hand and the favourable state of preservation of relics of material culture on the other, places Egyptologists in a privileged position in reconstructing the history of its inhabitants. Of these three source categories, material culture is an extensive body of evidence, much of which remains unstudied. Thus, the primary objective of the group is the systematic study of material culture from Egyptian settlements and cemeteries to obtain relevant data for the reconstruction of several aspects of socio-economic and cultural history. This includes insights into the daily life and death of elite and non-élite people as well as into local histories and regional developments in order to gain a more emic-informed, pluralistic view of ancient Egyptian culture and the society that created it. There is no specific limit in terms of period or object class, but any object is set within its context and therefore in a wider interpretational framework. We also look to neighbouring areas in order to overcome the still widespread bias of Egypt being perceived as a culturally isolated society. Through the prism of material culture we would like to incorporate Egypt into the broader framework of the Eastern Mediterranean but also Africa. Working with material from both on-going excavations and museum collections across the world, the work is firmly based on modern theoretical approaches to material culture. Using modern recording methods and analyses when possible, a bottom-up approach to Egyptian history is promoted and the somewhat neglected study of objects given a boost. In 2018 the Material Culture research group not only gained valuable new members, but also significantly expanded its time-frame, now, in addition to the Middle Kingdom, Second Intermediate Period and New Kingdom, also including Pre-and Early Dynastic material culture. Thus, alongside a multiregional approach, the research group also embraces an increasingly diachronic framework ranging from c. 3200 to c. $1295 \mathrm{BC}$.

\section{Current research}

\section{Beyond Politics}

PI: Bettina Bader, team: Lucia Hulková, Christian Knoblauch (to August 2018), Elke Kraft

After the successful evaluation of the project 'Beyond Politics' last year, the project entered into its second term. As before, our work concentrated on the study and documentation of assemblages of material culture of the Second Intermediate Period and organisation of this information
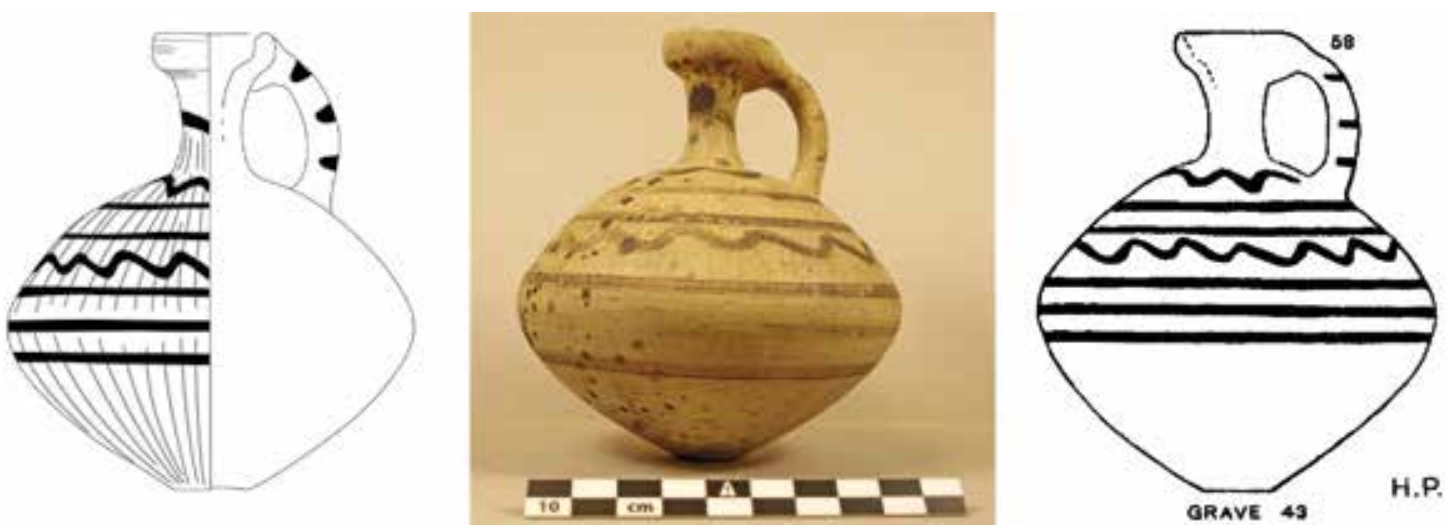

Fig. 53 E3484, Ashmolean Museum, re-recording, photo and original publication (photo: L. Hulková, (C) Ashmolean Museum) 
in the project database. Both work with new excavations as well as in museum collections was conducted. The material studied is derived from sites throughout Egypt and Nubia from Tell elDaba in the north to Kerma at the third cataract in the south. The sites where activities are being undertaken within the project are listed from north to south.

Work at Tell el-Daba was resumed in a month-long study campaign in co-operation with the Austrian Archaeological Institute, Cairo (OeAW). During this time, the photographic record of the find material of the late Middle Kingdom was updated as digital photography has improved greatly in the last decade (see also belwo, Tell el-Daba publications). The first volume of the final report (Tell el-Dabca XXIV. The late Middle Kingdom Settlement of Area A/II. A Holistic Study of Non-élite Inhabitants at Tell el-Daba, Volume 1 The Archaeological Report of the Excavations from 1966 to 1969) was accepted by the publishing house of the Austrian Academy of Sciences through peer review, and publication costs were awarded by the Austrian Science Fund (PUB 575-Z25). The volume is currently in press.

The focus of the season was, however, on selected contexts of a large, probably public building situated in Ezbet Helmi, alongside the early New Kingdom palaces. This building represents the final stage in the archaeological development in Area H/VI south and it provides find contexts for comparison with other sites in southern Egypt towards the end of the transition from the Second Intermediate Period to the New Kingdom. Several floor deposits were recorded and analysed. Of particular interest were large pottery storage jars in a presumably local fabric, which were still largely handmade according to a relatively ancient manufacturing tradition, with the rims turned on the wheel or turning device. Comparison with sites further south such as Ehnasya el-Medina promises to be of great interest (Bettina Bader).

The patchy state of archaeological exploration of the Nile Delta, especially concerning longterm modern research, is slowly improving, but the gap in available data is still felt keenly, especially for the Second Intermediate Period. For this reason, re-examination of material from the excavations carried out during the early $20^{\text {th }}$ century available in museums is important. At Tell el-Yahudiya a large number of tombs spanning the period from the Second Intermediate Period to the early New Kingdom were excavated by Flinders Petrie in 1905. Mostly complete tomb inventories were collected, regardless of the subjective quality or preservation of the objects. Thus, these assemblages present a rich corpus of provenanced material, available for modern study in museums. This year almost 70 objects from 16 graves in Tell el-Yahudiya were drawn, described and photographed in the Ashmolean Museum, Oxford and the Petrie Museum (University College, London). This study yielded details on the shapes and styles of these objects, their material composition and manufacturing technology (chaîne opératoire), all together information not available from the original publication. Our work also shows that the original drawings are quite accurate, just with too little detail (Fig. 53). Entering this data in the project database makes it available in a structured form and the site can be incorporated into the modern, bottom-up, object-based study of the Second Intermediate Period (Bettina Bader, Lucia Hulková).

Due to unexpected organisational difficulties, the planned 2018 excavation season in Tell el-Retaba did not take place. Nevertheless, the digitalisation of the available material from the Second Intermediate Period settlement and associated cemetery proceeded, as did the more detailed evaluation. The Harris matrix of the SIP units was finalised, as was the characterisation of individual phases of site occupation. The material from the 2017 season was prepared for publication in a preliminary report for the journal Polish Archaeology in the Mediterranean (in press) and for a more detailed article planned for the journal Egypt and the Levant (Lucia Hulková).

The archaeological sites of Harageh and Sedment approx. $60 \mathrm{~km}$ south of Cairo were excavated in the early $20^{\text {th }}$ century by W. M. F. Petrie and the British School of Archaeology. From Harageh, mainly a cemetery site, some tomb groups dating to the late Middle Kingdom/early Second Intermediate Period and later were studied (40 objects), also scant remains of a settlement were excavated and one relevant find group from House 530 was brought back to the UK, 
where it is housed in the Ashmolean Museum in Oxford. The 30 objects of this group, including stone vessels, net sinkers, scarabs, a mirror handle and chipped stone tools where re-studied and recorded with a focus on material analysis and manufacturing technology. Sedment, which lies a short way towards the south from Harageh, and only $7 \mathrm{~km}$ away from Ehnasya (see below), is an extensive area of cemeteries spanning the First Intermediate Period up to the $19^{\text {th }}$ Dynasty. The cemetery at Sedment/Mayana is particularly interesting for the current project because a number of tombs dated by Petrie to the " $16^{\text {th }}$ Dynasty" were found there and therefore potentially fill a chronological gap in this area. Whether the dating is tenable still needs to be verified. Some of the material was brought back to Europe and is now kept in the Ashmolean Museum, Oxford and the Petrie Museum (University College, London). Also, this material - pottery, wooden and faience objects - has been re-studied (Bettina Bader, Lucia Hulková).

Research at Ehnasya el-Medina was continued in co-operation with the Museo Arquèologico Nacional, Madrid under the direction of Carmen Pérez-Die. The analysis of the ceramic material of the soundings to explore the architectural history of the Hery-shef temple built by Ramesses II was continued and yielded - in the absence of other object types - ceramics as evidence for activity, inter alia, in the transition period from the very late Second Intermediate Period to the early New Kingdom. The ceramic material indicates that the latest possible date for this phase is the reign of Thutmose III. Recording of Soundings 1, 2 and 3 was finalised this year. The repertoire includes types known from the Nile delta in the same transition period such as flat-based cups, but also dishes with incurved rims and dark red and occasionally black slipped rims. The ring bases of such dishes were turned on the wheel or, if flat, show concentric circles from this treatment. Some parallels for this corpus were already seen at Abusir el-Meleq and Memphis. Moreover, a number of other Second Intermediate Period/early New Kingdom material from other areas of the site excavated years before, was located and photographed (Bader). The recordings already exist.

At Deir el-Bershah the study of the Second Intermediate Period material found in earlier seasons also continued, focusing especially on the chaine opératoire of the ceramic material, which, as usual, provided the largest object group. Differences in the manufacturing technology of hemispherical cups - one of the hallmarks of late Middle Kingdom and early Second Intermediate Period ceramic corpora - strongly suggest regional developments of this pottery type on a smaller geographical scale than hitherto acknowledged. The habitual dating by external parallel occurrence and similarity of these cups has been criticised before, but the more sites come under scrutiny, the more obvious differences in details become, casting doubt onto this habit, especially in the Second Intermediate Period, since this happens to be a pottery type in which regional differences are particularly apparent (Bettina Bader).

The analysis of the development of the material culture at Abydos during the Second Intermediate Period and on into the New Kingdom is well advanced and fieldwork finalised. One of the main results is that the changeover to a "new style" did not happen as a break in the traditions of material culture, but rather as a gradual development. The manuscript of Material Culture and Society: Abydos Assemblages from the

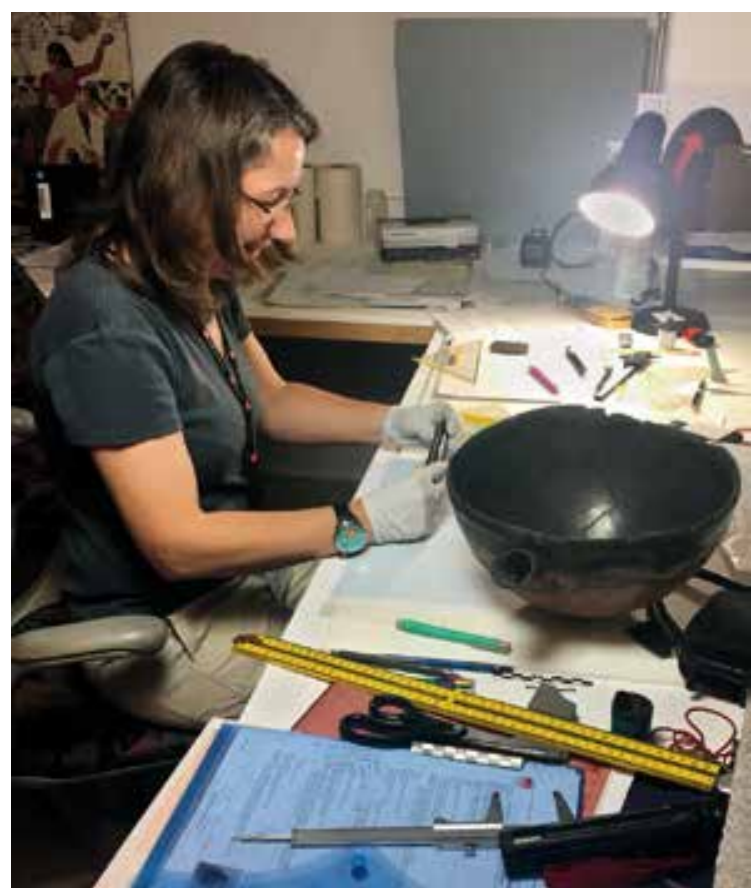

Fig. 54 Bettina Bader recording a Kerma vessel in the Museum of Fine Arts, Boston (photo E. Schuster) 
Late Middle Kingdom until the Early New Kingdom, is currently in preparation (Christian Knoblauch).

A new co-operation with J.-M. Galán directing the Djehuti Project in Western Thebes (Consejo Superior de Investigaciones Scientificas, Spain) allows us to study first hand a sequence of material culture from the early Middle Kingdom to the very early New Kingdom in this area, which fills gaps in knowledge derived from other sites with different context types in western Thebes (Bettina Bader).

Finally, the re-recording of the hitherto unstudied objects of several intact and near intact contexts from the large tumuli at Kerma (Sudan) was continued in the Museum of Fine Arts in Boston (Fig. 54). A few burials within the limits of each of the larger tumuli (nos. XI, X, IV and III) were chosen for re-analysis, covering the Second Intermediate Period. They give valuable clues not only for the internal sequence of these archaeological contexts, but also contribute insights about the recording method of G.A. Reisner, on whose results much subsequent research builds. Valuable first hand evidence was obtained through re-recording (Bettina Bader, Elke Kraft).

Funding: START-project 'Beyond Politics - Material Culture in Second Intermediate Period Egypt and Nubia' (Y754G19) awarded by the Austrian Science Fund (FWF), 1.1.2015-31.12.2020

\section{'Beautiful Kush'-Cosmetic substances and utensils in Egyptian New Kingdom Nubia}

\section{PI: Uroš Matić}

As part of his Post-doc project, Uroš Matić spent 2018 as a guest researcher at the OREA institute. The goal of this project is the analysis of cosmetic utensils (such as kohl-pots, -cases, and sticks; palettes; "cosmetic" spoons; tweezers; "curlers"; "trimmers"; razors and mirrors) and substances found in Nubian contexts of New Kingdom date and their comparison with similar objects found in contemporary New Kingdom contexts in Egypt. This comparison will show if there are any differences in the composition of contexts or use traces between the two areas. Moreover, the scientific analysis of galena started during this project in collaboration with the Museum Gustavianum in Uppsala and will give insights into the procurement and distribution of this material used in élite contexts to paint the eyes in the famous Egyptian way. During his stay, Matić has worked extensively on reassessing previous cultural-historical and colonial approaches to interrelations between Egypt and Nubia during the New Kingdom, completing his database and visiting European collections to (re-)record cosmetic utensils from Egypt and Nubia (Leipzig, Uppsala and Leiden), some for the first time. As the result of the work conducted at the OREA institute, several papers were presented at international conferences in 2018 (Current Research in Egyptology 2018 - Prague, $2^{\text {nd }}$ Sudan Studies Postgraduate Conference, 24 ${ }^{\text {th }}$ Annual Meeting of the European Association of Archaeologists in Barcelona, $21^{\text {st }}$ Sergeev's Readings - Moscow) or submitted for publication.

Funding: P.R.I.M.E (Postdoctoral Researchers International Mobility Experience) by DAAD (German Academic Exchange Service), 1.12.2016-30.6.2019.

\section{Centre or Periphery? The cemetery of Turah in the creative tension of state formation at the end of the $4^{\text {th }}$ and the beginning of the $3^{\text {rd }}$ millennium BC in Egypt}

PI: Vera Müller, team: Karl Burkhart, Nicola Math, Julian Posch

The project is devoted to the re-evaluation of tomb inventories from the cemetery of Turah and it was launched on September $1^{\text {st }} 2018$ by Vera Müller and her national co-operation partners Regina Hölzl, Director of the Egyptian-Oriental department of the Kunsthistorisches Museum (KHM), and Johannes Sterba, Senior Scientist at the Atominstitut of the Technical University of Vienna.

The cemetery of Turah was occupied from the late Predynastic Period to the end of the $1^{\text {st }}$ Dynasty (the final centuries of the $4^{\text {th }}$ mill. $\mathrm{BC}$ to the beginning of the $3^{\text {rd }}$ mill. $\mathrm{BC}$ ), thus encompassing the phase of state formation in Egypt. Situated only a few kilometres from the ancient 


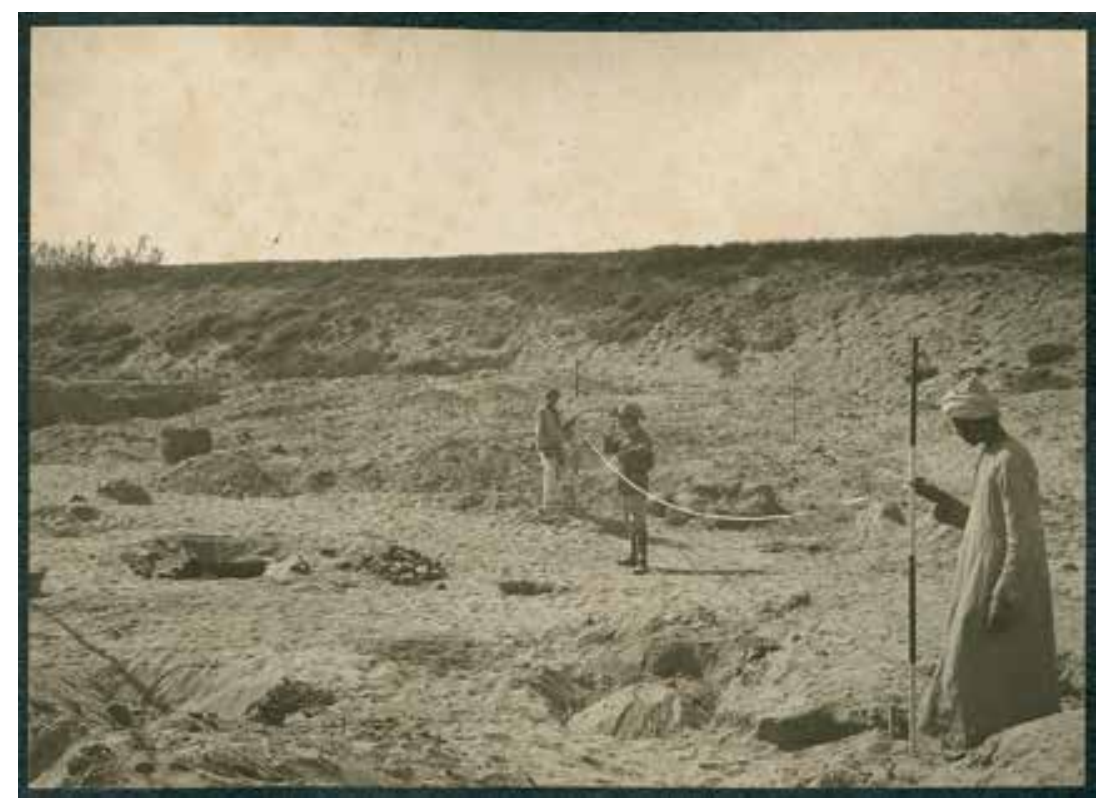

Fig. 55 The cemetery of Turah, 1910 (C Kunsthistorisches Museum)

capital Memphis and its main cemeteries at Saqqara and Helwan, a thorough intra-site and intersite analysis of this cemetery in relation to its contemporary equivalents will deliver important insights into the organisation of the centre and its peripheries as well as burial customs and trade and exchange patterns of this period, which are still only poorly understood. In order to achieve this, scientific analyses of the tomb inventories will be undertaken, such as petrography and neutron activation analysis of pottery vessels for provenance studies, as well as XRF and lead-isotopic analysis for copper objects. Due to the very bad preservation of human remains at Turah, only a single skeleton was transferred to Vienna. Nevertheless, several current scientific methods will be applied, such as aDNA and isotope analysis. Also, less spectacular finds will be scientifically studied, such as molluscs.

Excavated during the first few months of 1910, Hermann Junker was allowed to take all of the objects to Vienna except one harpoon head made of copper which was acquired by the Egyptian Museum in Cairo. The majority of the finds are housed in the KHM. Smaller numbers were given to collections in Krakau, Graz, the University of Vienna, Berlin, Hildesheim and Leipzig. While the Academy of Krakau supported the excavation financially, the museums in Germany received objects from Turah in exchange for artefacts from periods not or only badly represented in Vienna. The easy access to the objects means we can benefit from applying modern scientific methods, many of which are not available in Egypt. Moreover, the Egyptian authorities currently prohibit the export of samples. The analyses will thus help building up new methods and data which are already state of the art in European archaeology (Fig. 55).

In the original publication of 1912, Junker published the find material almost exclusively by means of photographs. Despite the exceptional number of photographs, the lack of drawings does not compensate for the difficulties in comparing the material to that from other cemeteries. It is therefore necessary to document the material entirely anew with drawings, modern photographs and thorough verbal descriptions. All data - the new as well as the old - will be made available at the end of the project in an open access database, which will be implemented and curated by the Austrian Centre for Digital Humanities (ACDH) of the Austrian Academy of Sciences. In addition, the analyses and results will be presented in printed form. These publications will form an important basis for a plethora of new research questions on this very intriguing period of state formation in Egypt.

Work started with the documentation of the objects in the KHM and the design of the database. Funding: Stand-alone project (P 31551) of the Austrian Science Fund (FWF), 1.9.2018-31.8.2022. 


\section{Outreach activities}

- 23.2.2018: Lucia Hulková presented: Hra o tróny: Egypt medzi Strednou a Novou ríšou (Game of Thrones: Egypt between the Middle and New Kingdoms), an Egyptological Lecture in the frame work of foundation Aigyptos in Bratislava, Institute of Oriental Studies of the Slovak Academy of Sciences and the Town museum of Bratislava (venue: Bratislava; Town Museum Bratislava)

- 8.3.2018: Lucia Hulková presented: Výskumy slovenských egyptológov na Tell el-Retábí (Research of the Slovak Egyptologists at Tell el-Retaba) a Lecture for Students organised by the University Library of the University of the Philosoper Constantine at Nitra (venue: Nitra; University Library of Nitra)

- 7.11.2018: Uroš Matić participated at the $3^{\text {rd }}$ Berlin Antiquity Slam - Stories about Antiquity in ten Minutes: „Gender, Schönheit und Körperpflege im Alten Ägypten“: https://lisa.gerdahenkel-stiftung.de/3._berliner_antiquity_slam?nav_id=7994\&fbclid=IwAR1hY2UGwMiU7 m59Dxyym_HOauO7/IdOYBPDushgSDGSbym4sY'BNELkAbY-E

Highlights 2018

- Aaron de Souza was awarded a Marie Skłodowska-Curie Fellowship for his project INBETWEEN - Reappraising Nubian Identity through Material Culture (grant agreement No 796050, 15.1.2019-14.1.2021).

- Uroš Matić spent 2018 at OREA by means of the DAAD's P.R.I.M.E. academic exchange Post-doc programme with his project 'Beautiful Kush'-Cosmetic substances and utensils in Egyptian New Kingdom Nubia.

- Uroš Matić received the Philippika-Preis from the German publisher Harrassowitz for the most outstanding dissertation in Ancient History.

- Award of FWF funding for the project 'Centre or Periphery?' (P 31551) with PI Vera Müller (collaborators N. Math, K. Burkhart, J. Posch) re-analysing the cemetery of pre- and early dynastic Turah.

- The publication Tell el-Dabc $a$ XXIV by B. Bader received full funding from the Austrian Science Fund (FWF-PUB575-Z25).

Bettina Bader - Lucia Hulková - Christian Knoblauch - Uroš Matić - Vera Müller 


\section{Tell el-Daba Publications \\ (coordinated by Vera Müller)}

\section{Objectives}

The aim of the research group is to prepare final publications of the long-term excavations at Tell el-Daba in the Eastern Nile Delta, from its beginning in 1966 until the excavator's (M. Bietak) retirement in 2009. Encompassing the period from the early Middle Kingdom until the middle of the New Kingdom (c. 2000-1300 BC), the site developed from a small planned settlement to a major harbour town with widespread international connections and functioned as the capital during the period of the Hyksos domination (c. 1650-1550 BC), before it was reintegrated into the Egyptian realm at the beginning of the New Kingdom and continued to serve as an important transfer shipment-centre. The site thus incorporates a wide range of Egyptian and Near Eastern cultural traits which are reflected in the architecture of domestic houses, palaces, temples and tombs as well as in the diversity of archaeological materials. The publications will therefore not only present these materials in their respective contexts, but will answer a range of research questions concerning the different spheres of life of the ancient inhabitants, who consisted of Egyptians as well as a wide range of foreigners. This research is conducted in close cooperation with the Austrian Archaeological Institute.

In addition, each member of this research group is engaged in further scientific activities, such as involvement in other excavations in Egypt (David Aston in Deir el-Bersheh and the Valley of the Kings at Luxor; Ernst Czerny at the Karnak temple in Luxor; Vera Müller at Abydos; Bettina Bader with her own research group 'Material culture' in several sites in Egypt and Sudan) or the Levant (Karin Kopetzky in diverse Levantine coastal sites and on her own new excavation project in Lebanon) as well as with the history of Egyptology (Ernst Czerny).

\section{Current research}

\section{Late Middle Kingdom settlement in Area A/II}

The final publication of the western part of Area A/II (vol. 1) by B. Bader was accepted for print by the peer review process of the Austrian Academy publication committee under the title Tell el-Dab a XXIV. The late Middle Kingdom Settlement of Area A/II. A Holistic Study of Non-élite Inhabitants at Tell el-Dab a, Volume 1 The Archaeological Report of the Excavations from 1966 to 1969, and publication (incl. open access) costs were awarded by the Austrian Science Fund (PUB 575-Z25).

A detailed analysis of the typical domestic house ground plans (two rooms of uneven widths in an almost square house) of the settlement including measurements and comparanda from all over Egypt and other sources was published. This study also includes non-archaeological sources and a survey in Syria-Palestine in the Middle Bronze Age II-A. Other topics such as the distribution

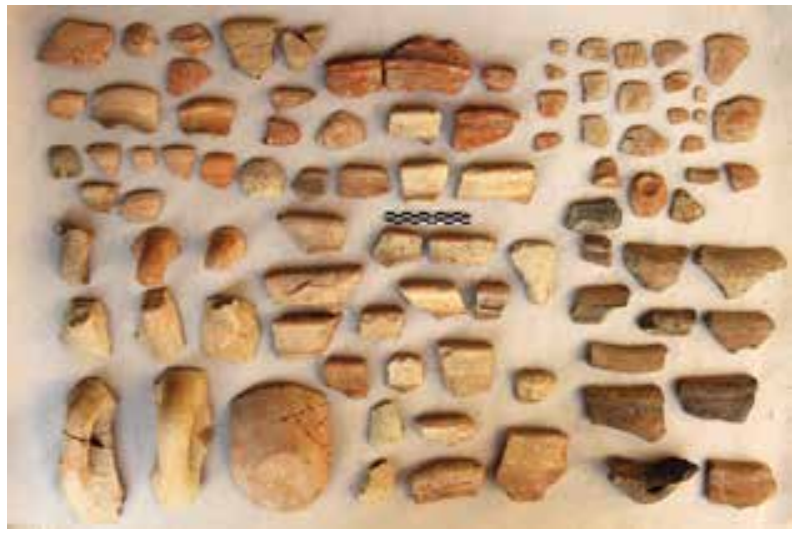
of storage facilities and the layout of the narrow alleyways were also discussed (see bibliography).

In a study season in September 2018 at Tell el-Daba it was possible to update the photographic documentation with digital photos (Fig. 56) of the archaeological finds for the planned second volume of the late Middle Kingdom settlement, namely the eastern part.

Fig. 56 Pottery Assemblage K 2030 of the late Middle Kingdom (photo: B.Bader, (CÖAI/ÖAW) 


\section{Temple rituals in Area A/II}

After the reopening of the Tell el-Daba site after a break of 2.5 years in autumn 2018, Vera Müller continued the documentation of archaeological relics deposited in the forecourts of the temples in the religious compound in area A/II. This area was excavated in the early years of the Austrian mission, therefore it is necessary to document most of the material anew with state-of-the-art recording methods. During the five weeks at Tell el-Daba a large part of the material was documented and recorded.

According to the architectural analyses by Manfred Bietak, the temple compound consisted of two temples in Egyptian layout and two of Near Eastern layout. Interestingly, the coexistence of Egyptian and Near Eastern features is not reflected in the relics encountered in the forecourts of these temples. On the contrary, the proportion of pottery vessels in the Levantine style is much lower than in other contexts, such as tombs or the settlement. Another interesting result is the small number of vessels confined to ritual contexts. The majority of vessels are also known from daily life contexts in the settlement, with the exception of a rather low proportion of storage jars. This combination of vessel types raises general questions on the specificity of objects used in temple cults. Do objects used in a religious context have to be recognizable as such or were the majority also used in daily life?

\section{Necropolis in Area F/I}

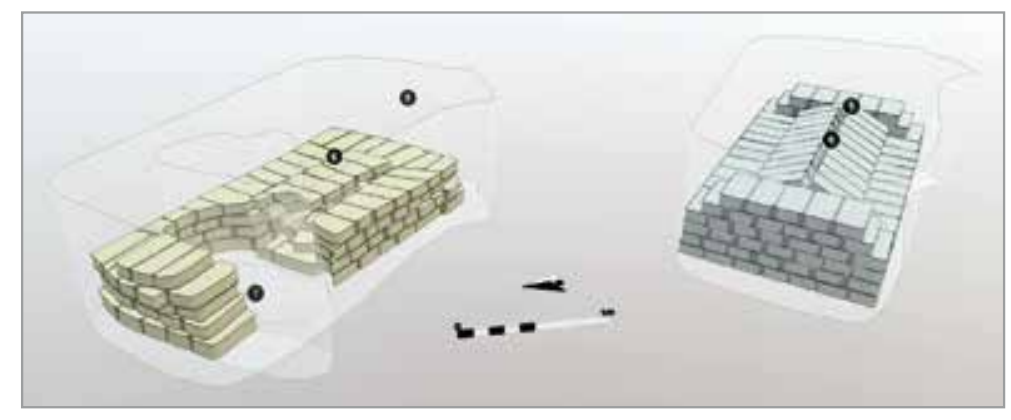

Fig. 57 3D-model of Tomb F/I-/21 no. 8. Left: based on field documentation, right: reconstruction of architecture (graphics: S. Fragner, (C) OREA)
Karin Kopetzky continued her research of the tombs of area F/I (Fig. 57). Together with Zuzanna Wygnańska, she organized the workshop "Middle Bronze Age Tombs and their Funerary Environment from Syria to Egypt" at the $11^{\text {th }}$ ICAANE in Munich. The aim of this workshop was to shed more light on the similari-

ties of and differences in spatial organisation (intra vs. extra-mural) and layout of cemeteries, on the types of tombs used in various regions and the burial customs and rituals during and after the entombment of the deceased covering the area from Northern Syria to Egypt. Karin Kopetzky focused on "Buried in Avaris - a fusion of Egyptian and Near Eastern funerary customs", investigating the reasons for geographical locations and re-locations of cemeteries at the site over the period of nearly 300 years. Changes are not only mirrored in the shifted locations and the layout of the cemeteries, but also in the architecture of the tombs and the burial habits reflecting changes in the religious perception of the inhabitants of Avaris and their concept of the afterlife.

\section{Pit System 'L81' in Area F/II}

The final comprehensive publication by David Aston of the finds from the huge assemblage called Locus 81 (L81), comprising over 35,500 diagnostic sherds and a number of small finds dating to the Second Intermediate Period has significantly advanced. Although some smaller find groups and individual objects have already been published or are currently in press (with two further articles on some aspects of the pit and its finds being written in the past year), full treatment of all the material is still some way off, but during 2018 a large part of the existing drawings were inked and digitized. Currently some 800 of 1,400 A3 sheets have been so treated, which is an important step towards final publication. 


\section{Scarabs and Sealings from Ezbet Helmi}

Ernst Czerny continued to study the seals and sealings from Ezbet Helmi and to prepare the collection of 480 objects (scarabs, scaraboids, amulets, plaques and sealings) for publication.

\section{Pottery Corpus of Ezbet Helmi, Area H/VI}

The comprehensive pottery analysis by David Aston of the material of 9 phases in Tel el-Daba Area H/VI spanning the late Second Intermediate Period to the mid- $18^{\text {th }}$ Dynasty made good progress. The catalogue and plates detailing some 4,250 pieces are ready, whilst introductory comments and the typological discussion of the pottery types and their development, including discussions of parallels at other Egyptian sites as well as local developments during the course of these phases is well advanced.

\section{'Building L'at Ezbet Helmi}

The actual focus of Bettina Bader in the study season at Tell el-Daba in September 2018 was the continuation of the analysis of ceramic finds in a large public building ('Building L') of the early New Kingdom in Ezbet Helmi, derived from closed loci such as floor deposits, for use as a comparative body of material for the project Beyond Politics (see above, research group Material Culture in Egypt and Nubia). The contexts studied belong to the floors of a series of rooms in the building, and an interesting ceramic assemblage came to light including large storage jars (Fig. 58).

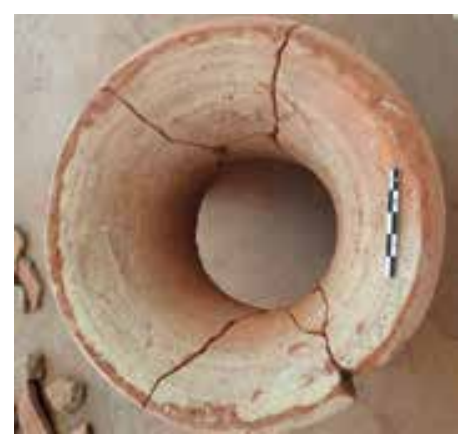

Fig. 58 Storage Jar (Inv.-No. 8987 D) of the New Kingdom (photo: B. Bader, (C) ÖAI/ÖAW)

\section{Digitizing the Tell el-Daba archive}

The rich excavation documentation of Tell el-Daba collected from nearly 50 years (1966-2009) of excavating in the Eastern Nile delta in Egypt is currently digitized within the "A Puzzle in 4D" project, which is funded by the Österreichische Nationalstiftung für Forschung, Technologie \& Entwicklung (DH 2014/12) and embedded within the DIGital Documentation Lab (coordinated by Edeltraud Aspöck).

The aim of this project is to provide digital long-term preservation for the various archaeological resources of archaeological excavations dealing with old (analogue) and modern (digital) documentation systems. In her function as custodian of the Tell el-Daba archive, Karin Kopetzky is the archaeological consultant to this project. So far, more than 70,000 analogue documents have been scanned and provided with metadata following the CIDOC CRM model by Karl Burkhardt, Stephanie Fragner, Julian Posch and Martina Simon. This work will be continued in the next year (see also: Below DIGital Ducumentation Lab and https://4dpuzzle.orea.oeaw.ac.at/)

\section{Egypt in the Levant}

For the project Egypt in the Levant, the study of the Egyptian imports from the Middle and New Kingdom to the sites of Sidon (British Museum excavation) and Tell Fadaous-Kfarabida (American University excavation) was continued by Karin Kopetzky. It is the continuation of an MSCA project (no. 253671), which was conducted from 2011-2013 at Harvard University and the Austrian Academy of Sciences. One of the results of this project, the synchronisation of Tell el-Daba and Byblos, is published in the 2018 volume of Egypt \& Levant. In this, study material found inside the Royal Tombs I, II and III of Byblos was studied in detail, compared with stratified finds from Tell el-Daba and, as a result, dated to the early MB IIB and MB IIC periods, about 120 years later then generally believed. 


\section{Further Activities}

Other activities by David Aston concentrated on excavations conducted in the Valley of the Kings in Luxor, where he collaborated with the team from the University of Basel in Tomb KV 40, the Pacific Lutheran University (Tacoma, WA, USA) in tombs KV 48 and 50-52 and the American University in Cairo in KV 63. In all these projects he studied the ceramic material for final publication. The chapter of the final report on KV 64 and 40 on the New Kingdom pottery has already been written and awaits publication.

A quite small but very well dated body of material deriving from the $26^{\text {th }}$ Dynasty is the subject of a new co-operation with the Swiss Institute in Cairo at Elephantine where he also worked in the past year. Moreover, the co-operation with the University of Leuven excavations at Deir el-Bersheh made good progress, as recording of the $18^{\text {th }}$ Dynasty pottery from Sheikh Said is almost finished and will only need one more season to be completed.

In February and March, Ernst Czerny was working with the IFAO mission led by Irmgard Hein (University of Vienna) at Karnak-North. The mission's aim is to study and publish the many thousand objects which were excavated by the late Helen and Jean Jaquet, but have remained unpublished. This season's work concentrated on the study of decorated limestone chips, the remains of the destroyed walls of the treasury of Thutmose I (Early $18^{\text {th }}$ Dynasty).

Vera Müller spent one month at Abydos at the excavation of the German Archaeological Institute, Cairo to complete her documentation on the inventory of King Den's tomb dating to the $1^{\text {st }}$ Dynasty. During this season, in addition to a selection of pottery vessels, a varied range of unsealed jar stoppers were documented which differ in several aspects from the sealed stoppers and reveal a large variety of different devices with which the jars were closed: pottery lids, pottery sherds, balls made of straw or lumps of textiles. In addition, the lithic material from this tomb was analysed by the two French specialists, B. Midant-Reynes (CNRS, former director of the IFAO in Cairo) and F. Briois (University of Toulouse).

While David Aston carried on with the editing of the volume by Perla Fuscaldo, Tell el-Dab ' $a$ $X / 3$, Ernst Czerny continued editorial work on the monumental 2-volume monograph by Penelope Mountjoy Decorated Pottery in Cyprus and Philistia in the 12 $2^{\text {th }}$ Century BC: Cypriot IIIC and Philistine IIIC, which finally appeared at the end of May 2018. There followed editorial work for Egypt and the Levant 28 (2018), which is going to be published shortly after the turn of the year ( 22 contributions: two obituaries, two preliminary excavation reports, 18 articles).

Bettina Bader is simultaneously the group leader of the research group Material Culture in Egypt and Nubia, into which Vera Müller was integrated in autumn 2018 with her new FWF-funded project Centre or Periphery?. Karin Kopetzky's FWF project Between the Land and Sea: The Chekka region in Lebanon was transferred to the research group Mediterranean Economies in 2018.

Ernst Czerny was co-coordinator of the research platform History of Research. He was involved in the organisation of a two-day workshop "Archäologie und Republik" (to take place at the end of January 2019), which will include a section entitled "Egypt".

\section{Events}

- Workshop organised at $11^{\text {th }}$ ICAANE in Munich on the $5^{\text {th }}$ of April 2018 by K. Kopetzky together with Z. Wygnanska (University of Warsaw) on Middle Bronze Age Tombs and their Funerary Environment from Syria to Egypt

\section{Outreach Activities}

- 13.-15.7.2018: Vera Müller, Bericht zu den ägyptologischen Aktivitäten des Instituts für Orientalische und Europäische Archäologie (OREA) der ÖAW. Ständige Ägyptologenkonferenz (SÄK) Münster 
- 16.4.2018: lecture by Vera Müller, Ein Friedhof voller Rätsel: der frühzeitliche Königsfriedhof in Abydos, Institut für Ägyptologie, Ägyptologische Gesellschaft Wien

- 5.4.2018: lecture by K. Kopetzky, Buried in Avaris - a fusion of Egyptian and Near Eastern funerary customs, in Workshop on Middle Bronze Age Tombs and their Funerary Environment from Syria to Egypt, organzized by K. Kopetzky and S. Wygnanska at the $11^{\text {th }}$ ICAANE, Munich

\section{Highlights 2018}

- The publication Tell el-Dab'a XXIV received full funding from the Austrian Science Fund (FWF- PUB 575-Z25) applied for by B. Bader

- Reopening of the excavation site Tell el-Daba after a break of 2.5 years for political reasons

David Aston - Bettina Bader - Ernst Czerny - Karin Kopetzky - Vera Müller 


\section{MediterRanean ECONOMIES}

(Research group leader: Reinhard Jung)

\section{Objectives}

In its approach, this research group combines archaeological case studies with economic theory. The development of the forces of production constitutes a decisive factor in the history of social relations in all human societies and determines contacts between societies to a large extent. Therefore, modes of production, including property relations as well as exchange processes between different Mediterranean societies, are in the focus of the projects conducted by the scholars in this group. A first level of research relates to the establishment of chronological frameworks in order to define for each site and project its proper historical context. At a second level, the research questions target the economic basis as well as related social structures and political institutions. This includes local and regional perspectives as well as interregional product exchanges and mobility. All the projects cooperate closely with colleagues from a wide array of archaeometric disciplines - e.g. for analyses of different find materials (pottery, metals, biological remains) or for chronological purposes $\left({ }^{14} \mathrm{C}\right)$. In order to arrive at historical conclusions, written sources - if available - are analysed in a comparative way as well. The projects deal with different pre-state and early state societies in the Mediterranean and circum-Mediterranean regions ranging from Italy in the West to the Levant in the east and from the central Balkans in the north to Egypt in the south.

In the "Zentral-Cafe", which is directly affiliated to the research group, researchers from different OREA research groups as well as from the University of Vienna meet in discussion. They come from various disciplines of archaeology and social anthropology and work on chronological periods from the Neolithic up to modern times. Our discussions centre on important economic theory texts on the one hand and specific case studies from archaeology and anthropology on the other.

\section{Current research}

Between Land and Sea: The Chekka Region in Lebanon. An Archaeological and Paleo-environmental Approach towards the Potential of an East Mediterranean Coastal Region

\section{PI: Karin Kopetzky}

In May 2018, this new project funded by the FWF started with a geophysical survey at Tell Mirhan in Lebanon. An excavation conducted on site from June $11^{\text {th }}$ to July $7^{\text {th }}$ followed this first investigation. The excavations in two areas revealed a massive fortification system from the Middle Bronze Age and the remains of walls dating to early Iron Age phases. The quantity of imports from Egypt, Cyprus, Mycenaean as well as Iron Age Greece is surprising and shows that Tell Mirhan and the Bay of

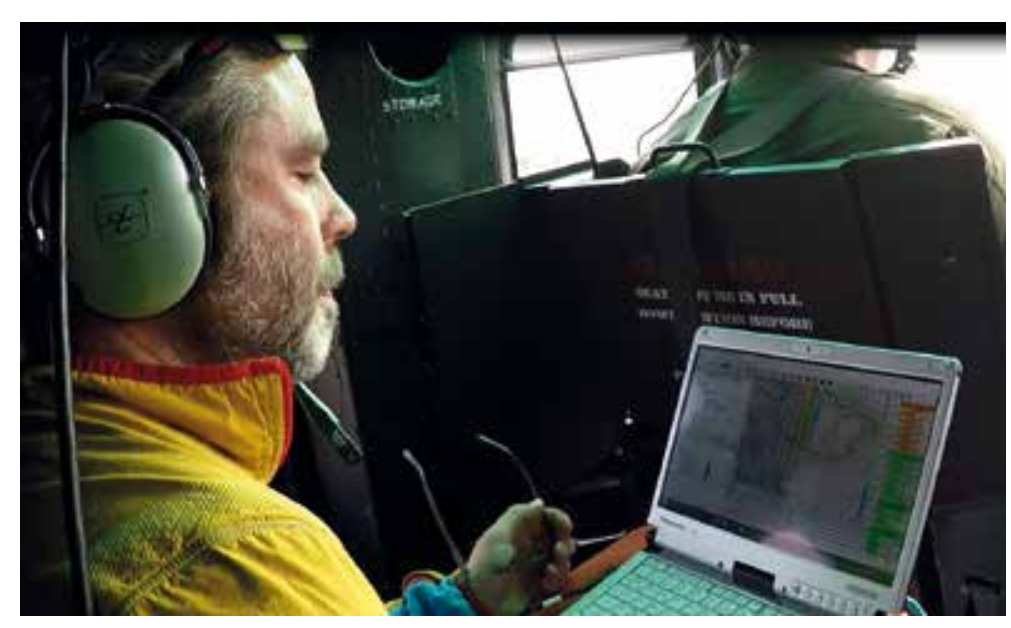

Fig. 59 F. Haas LiDAR scanning in the Chekka region (Lebanon) (photo: K. Kopetzky, C OREA)
Chekka were well integrated in the trading networks of the Eastern Mediterranean during both periods. To gain a better understanding of how this coastal area communicated with and was connected to its hinterland, a LiDAR survey (Fig. 59) of the area between the coast, the Wadi Asfur and the Lebanon mountains was conducted in cooperation with Florian Haas from the Institute of Physical Geography of the Catholic University of Eichstätt-Ingolstadt in 
November 2018. Florian Haas operated the Riegl VP1 Helicopter pod for airborne laser scanning during the flight and is in charge of processing the data collected. The Lebanese Army was an indispensable partner in this venture and thankfully supported the scientists vigorously and with utmost efficiency, the pilots fulfilling this rather tricky task with precision and dedication.

Funding: FWF 30581

\section{Studies on the new Mycenaean Palace of Ayios Vasileios in Laconia}

\section{PI: Reinhard Jung}

This research project entered its third year and final phase. The first objective of the project was to provide a chronological framework for the construction and destruction phases of the recently identified Mycenaean palace in the south-eastern Peloponnese (the ancient name of the site is still unknown). The second objective was to characterise the pottery tradition used in the palace in a broader chronological and geographical sense by means of provenance and technological studies (neutron activation analysis - NAA, thin section petrography and x-ray analysis).

In order to accomplish these tasks, Eleftheria Kardamaki has completed the detailed recording of more than 4,500 feature sherds from various excavated contexts of the palace. These form the basis for the typological, macroscopic and statistical analysis of the material. Among the most valuable results of this research project were dating the destruction of the palace to the first part of the $13^{\text {th }}$ century BCE and understanding aspects of change and continuity in the pottery manufacturing traditions of Laconia from the $16^{\text {th }}$ to the $13^{\text {th }}$ century BCE. Since Laconia played a pivotal role in the development of the Late Bronze Age pottery styles of the Greek mainland, these were valuable insights into diachronic aspects of Late Bronze Age pottery technology and styles.

Furthermore, a new group of sherds was sampled for NAA, petrography and organic residue analysis (ORA). In total, 130 and 90 sherds for NAA/petrography and ORA respectively, together with 19 samples for x-ray analysis, offer valuable information regarding the production strategies and technological choices of pottery workshops in Laconia. Our scientific partners and Maria Choleva (UC Louvain, x-rays), Peter M. Day (University of Sheffield, Petrography), Anno Hein and Vassilis Kilikoglou (NCSR "Demokritos", NAA) and Cynthianne Spiteri (University of Tübingen) have reached preliminary results and several joint articles are in preparation. Two articles about pottery typology, stratigraphy and architecture submitted by Eleftheria Kardamaki and co-authors are forthcoming.

Funding: FWF 28023

\section{Bronze Age Gold Road of the Balkans - Ada Tepe Mining}

\section{PI: Barbara Horejs}

In 2018, the research activities of this project funded by the FWF focused on the cultural-historical contextualisation of the north-eastern settlement on the Ada Tepe and on contacts between the Aegean and the Balkans during the Late Bronze Age. Laura Burkhardt pursued further methodological training as well as practical comparative studies. She attended workshops on ceramic petrography and network analysis and undertook an extensive study trip to museums on the Balkans. Based on that, she started a collaboration with Clare Burke, the petrographer of the OREA institute, in order to investigate the technological aspects of the pottery found in the north-eastern settlement on the Ada Tepe mound. In the framework of a two-month ATHENS scholarship from the ÖAI, Laura Burkhardt visited different museums in northern Greece. She then presented the results of her comparative investigations and theoretical studies in a public lecture at the Austrian Archaeological Institute in Athens (November 14 $4^{\text {th }}$ ). Yana Dimitrova (Institute of Archaeology and Museum, Bulgarian Academy of Sciences) and Petar Minkov (Sofia University "St. Kliment Ohridski") conducted comparative studies of the material culture of the Metal Ages at OREA from November 1, to December 15, 2018.

Funding: FWF 28451 
The Collapse of Bronze Age Societies in the Eastern Mediterranean: Sea Peoples in Cyprus?

PI: Peter M. Fischer (University of Gothenburg, Sweden); co-researcher: Teresa Bürge

Within the project The Collapse of Bronze Age Societies in the Eastern Mediterranean: Sea Peoples in Cyprus? (The Swedish Research Council [Vetenskapsrådet]) the excavations continued at the Bronze Age city of Hala Sultan Tekke with its ninth season lasting from May to June 2018. In City Quarter 1, industrial and domestic structures belonging to three phases of occupation (Strata 3-1) were exposed: These can be dated to the end of the $13^{\text {th }}$ and the first half of the $12^{\text {th }}$ centuries BCE (phases LC IIC-IIIA). Additional evidence for intra-urban copper production in Strata 3 and 2 was obtained by finds of almost $500 \mathrm{~kg}$ of copper slag together with remains of furnaces and tuyères.

A magnetometer survey covering 23 ha and carried out in 2017 had brought to light new parts of the city and demonstrated its vast size. The most striking feature is a large architectural compound, City Quarter 4, located approximately $140 \mathrm{~m} \mathrm{SW}$ of City Quarter 1 . The excavations uncovered several walled spaces, where, inter alia, numerous large broken storage and transport vessels were found. One of the spaces is a 'bathroom' (Fig. 60), the walls and floor of which are coated with ashlar slabs and a thick layer of fine plaster, demonstrating an advanced hydro-technical construction. There is a water inlet just above the floor, which slopes down towards a drain on the opposite side. The structures exposed so far are synchronous with Stratum 1 in City Quarter 1, judging by the pottery evidence.

Excavations also continued in Area A, a suburban area just SE of the city, where Late Cypriot wells, offering pits and tombs had been found in previous seasons. A large, roughly figure-8shaped anomaly indicated by the magnetometer survey was targeted by excavation and turned out to be a LC II tomb (Tomb RR). The two interconnected chambers contained 13 skeletons, in addition to numerous tomb gifts of Cypriot, Mycenaean, Minoan and possibly Egyptian provenance. Amongst the most imposing finds is a large, complete Mycenaean chariot krater.

The 2018 season of excavation yielded numerous ${ }^{14} \mathrm{C}$ samples to be analysed by Eva Maria Wild (VERA laboratory Vienna). Preliminary results of the samples from previous seasons were presented at the $23^{r d}$ International Radiocarbon Conference in Trondheim in June 2018. The study of petrographic samples is carried out by Paula Waiman Barak (University of Haifa); pottery samples for NAA are processed by Johannes Sterba (Technical University of Vienna). Preliminary results revealed numerous ceramic imports from the Aegean (including Crete), Anatolia, the Northern and the Southern Levant, and Egypt. In addition, specific regions of provenance for Cypriot pottery could be identified.

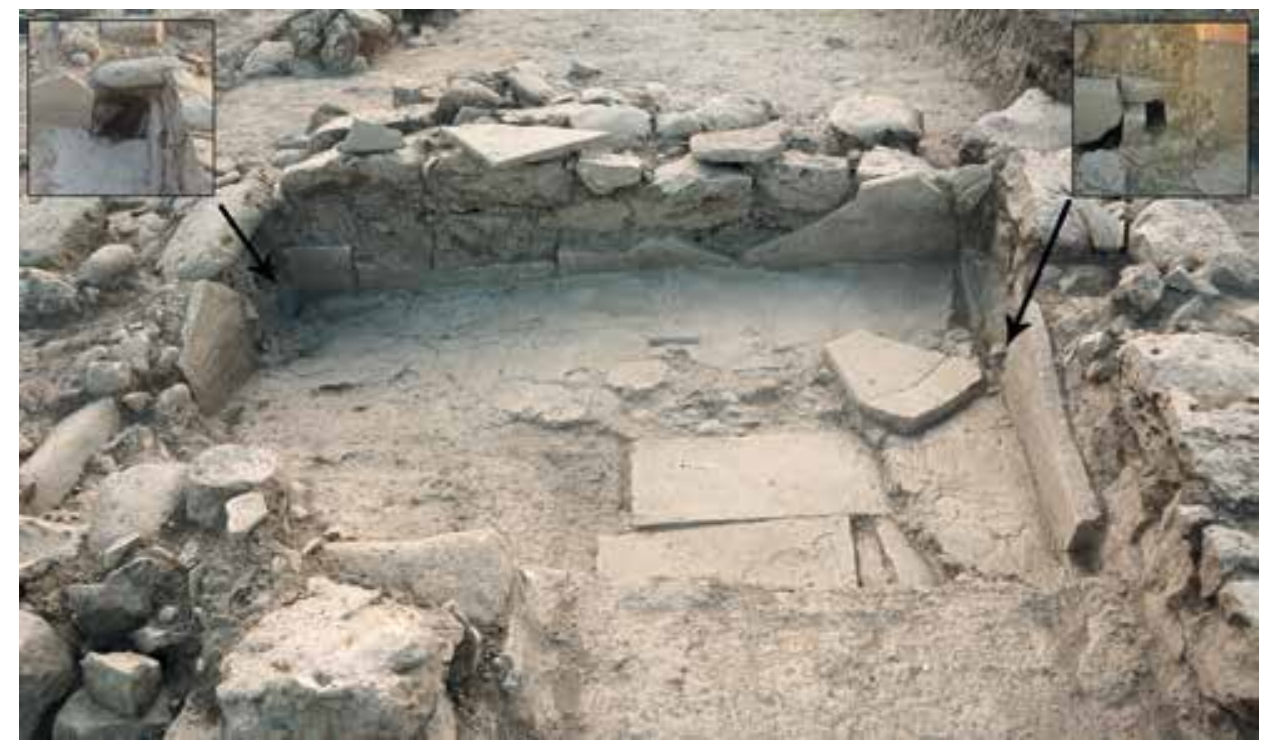

Fig. 60 Hala Sultan Tekke (Cyprus), City Quarter 4, Stratum 1, 'bathroom' with inlet (upper right) and drain (upper left) (photo/C P. M. Fischer) 


\section{Dietary and Mobility Reconstruction Using Stable Isotope Analyses for Mycenaean Greece: the Case of Portes}

$\mathrm{PhD}$ project by Annalisa Rumolo

In this project funded by the Gerda-Henkel-Stiftung and supported by the OeAW, two main tasks are the reconstruction of diet and mobility of targeted individuals at the cemetery of Portes in Achaea (north-western Peloponnese) and a general reassessment of published isotopic and archaeological evidence from coeval Mycenaean sites. In 2018 at the University of Southampton, A. Rumulo conducted C, N and Sr isotope analyses on skeletal materials from Portes under the supervision of Alistair Pike (Fig. 61). The application of the innovative laser ablation technique (ICP-MS) is providing a very fine chronological resolution for assessing residential mobility.

From June to September, Annalisa Rumolo held an ÖAI ATHENS scholarship, undertook comparative research and met with scholars working on the evidence for Mycenaean nutrition at other sites. Thanks to the courtesy of Olympia Vikatou, director of the Ephorate of Antiquities of Aetolia-Acarnania and Leukas, Annalisa Rumolo can now enlarge the project database by including funerary contexts from the LH IIIA1 to the LH IIIC cemetery site of Mageiras (excavated by O. Vikatou) in the neighbouring region of Elis. Human skeletons from eight chamber tombs will be investigated by means of stable isotope analysis. This will enable a comparison between the diet and mobility of two western Peloponnesian communities, adding to the evaluation of new against previously published data.

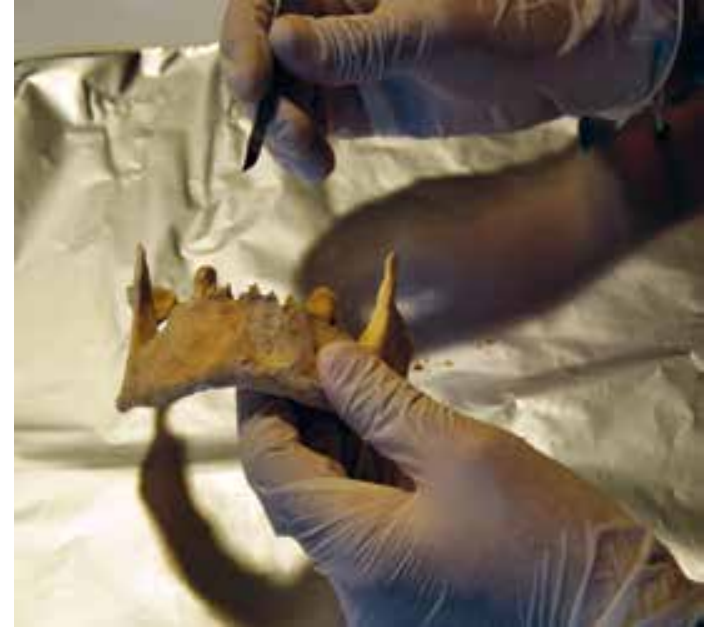

Fig. 61 Tooth sampling of an individual from Portes (Greece) (photo/C A. Rumolo)

Gerda-Henkel-Stiftung, doctoral scholarship for A. Rumolo

In March and April 2018 Reinhard Jung joined the excavation team of Pyla Kokkinokremos (southern Cyprus) upon invitation by the directors Joachim Bretschneider, Jan Driessen and Athanasia Kanta to coordinate the pottery study of that ongoing research project. For July, Claude DoumetSerhal invited him to coordinate the Mycenaean pottery study at her excavations at Sidon, College Site (southern Lebanon). In both cases, Reinhard Jung started to educate young researchers in pottery documentation and study.

\section{Events}

- 4.4.2018, Munich: P. M. Fischer and T. Bürge organized the workshop Bronze Age Cyprus: Regionalism versus Interculturalism at the $11^{\text {th }}$ ICAANE in Munich including papers by P. M. Fischer, T. Bürge and P. Waiman Barak, presenting preliminary results of the project The Collapse of Bronze Age Societies in the Eastern Mediterranean: Sea Peoples in Cyprus?

- 8.-9.11.2018, Vienna: R. Jung and E. Kardamaki organised an international workshop with the title Synchronizing the Destructions of the Mycenaean Palaces at OREA. The speakers presented their latest results on different destruction events at Mycenaean palaces (including Ayios Vasileios) and some other major sites from southern Greece, Crete, Cyprus and the Levant. The proceedings of the conference will be submitted for publication in 2019 .

- 13.-15.6.2018, Vienna: In order to further deepen and promote scholarly discussions on prehistoric economies - a field already well established with the "Zentral-Café" - an international symposium entitled The Critique of Archaeological Economy was held at OREA. The 
organisers R. Jung (OREA) and St. Gimatzidis (ÖAI) brought together scholars from different archaeological, anthropological, historical and economic disciplines, who offered critical discussions of models currently in use for pre-capitalist economic systems, while at the same time presenting alternative theoretical approaches.

\section{Outreach activities}

- 29.11.2018: The Südwestfunk (Baden-Württemberg, Germany) broadcasted an interview with K. Horst, R. Jung, and J. Maran on Mycenaean Greece, on the occasion of the opening of the large Mycenae exhibition at the Landesmuseum Karlsruhe ("Mykene - Die sagenhafte Welt des Agamemnon"). See https://www.swr.de/swr2/programm/sendungen/swr2-forum/mykenearchaeologie-schliemann-schaetze-hochkultur-griechenland-peloponnes-kulturhistorischhomer/-/id=660214/did=22687860/nid=660214/1v2nmpi/index.html

- 1.9.2018: Die Presse, Von den Zedern des Herrn, https://diepresse.com/home/science/5489120/ Von-den-Zedern-des-Herrn

- 24.4.2018: M. Hennies interviewed S. Deger-Jalkotzy, R. Jung and J. Maran for the programme „IQ - Wissenschaft und Forschung“ of the Bayerischer Rundfunk (Germany) in a feature with the title „Das rätselhafte Ende der Bronzezeit - Klärung in Sicht?“" dealing with the end of many social systems in the Eastern Mediterranean around 1200 BCE. See https://www.br.de/ mediathek/podcast/iq-wissenschaft-und-forschung/das-raetselhafte-ende-der-bronzezeit-klaerung-in-sicht/ 676744

- 28.3.2018: Der Standard, Zedern des Pharaos, https://derstandard.at/2000076858185/Zedernfuer-den-Pharao

- The Swedish radio station Sveriges Radio visited the Hala Sultan Tekke excavations in June 2018 and broadcasted a programme about the current project on the Late Bronze Age collapse. See https://sverigesradio.se/sida/avsnitt/1089577?programid=407

\section{Highlights 2018}

- P. M. Fischer and T. Bürge published Two Late Cypriot City Quarters at Hala Sultan Tekke. The Söderberg Expedition 2010-2017 (Studies in Mediterranean Archaeology 147), which is the first final publication volume of the new Swedish expedition at Hala Sultan Tekke.

- For the first time in Lebanon, LiDAR scanning was conducted within the framework of the project Between Land and Sea: The Chekka Region in Lebanon. The aim of this endeavour covering an area of more than $100 \mathrm{~km}^{2}$ is to get a diachronic picture of how a coastal site interacted with its hinterland and how this changed over time.

- The exhibition The First Gold: Ada Tepe the Oldest Gold Mine in Europe (March $7^{\text {th }}$ to June $25^{\text {th }} 2017$, at the Kunsthistorisches Museum, Vienna) was the most visited archaeological exhibition worldwide in the year 2017 and took the first place in the international ranking in the category Antiquities. ${ }^{*}$ An updated version of the exhibition was shown in Sofia from 25.10.2017-28.1.2018

Teresa Bürge - Laura Burkhardt - Reinhard Jung Eleftheria Kardamaki - Karin Kopetzky - Annalisa Rumolo

Ranked: the top ten most popular shows in their categories from around the world, The Art Newspaper, March $26^{\text {th }} 2018$, see https://www.theartnewspaper.com/feature/top-10-exhibition-and-museum-visitor-figures-2017 (last accessed December $18^{\text {th }} 2018$ ) 


\section{The Mycenaean Aegean: \\ Cultural Dynamics from the Middle Bronze Age to the Early Iron Age}

(Research group leader: Birgitta Eder)

\section{Objectives}

The work of the Mycenaean Research Group covers various aspects of the Late Bronze Age cultures of the Greek Mainland and the Middle Bronze Age strands of its genesis (Minoan Crete, Middle Helladic mainland) as well as its transformation into the Greek Early Iron Age. Various projects study aspects of the political structures of Mycenaean Greece and its political geography, the northern and western regions of Mycenaean Greece, the relations between the Greek mainland and Crete during the Late Bronze Age, the textual evidence of the Linear B documents, Mycenaean cult practice and rituals, but also Middle Helladic and Early Mycenaean pottery, burials and habitation sites. The geographical scope includes all areas of the Mycenaean civilisation from Thessaly to Crete and from the Ionian Islands to the Dodecanese and the coast of Asia Minor. Several projects are dedicated to the preparation of final excavation reports and the interdisciplinary evaluation of Middle Bronze Age and Mycenaean pottery.

\section{Current research}

\section{Middle Bronze Age Pottery from the Peloponnese Archaia Pheneos}

PI: Michaela Zavadil; project staff: Clare Burke, Georgia Kordatzaki

M. Zavadil continued studying the MH pottery from the excavations on the acropolis of Archaia Pheneos (Corinthia) in the museum at Archaia Pheneos. In 2018 her work was again dedicated to the rich corpus of MH III/LH I pottery (Fig. 62).

Clare Burke undertook petrographic analysis of 147 samples of the pottery covering the time span between EH III/MH I and the Mycenaean period. The material is dominated by two main petrographic fabrics, which are consistent with the geology of the landscape surrounding the settlement and thus testify to the dominance of local pottery production. Imported pottery is very rare within the assemblage: this impression already arose in the course of the macroscopic examination of the pottery and was confirmed by the work of Clare Burke; within the sampled material only two imports clearly appeared, which originate from Aegina.

A one-week stay by Georgia Kordatzaki (Research Associate, Fitch Laboratory of the British School at Athens) was devoted to working with Michaela Zavadil to examine the prehistoric pottery for macroscopically detectable traces of their manufacture. These traces provide information on the techniques applied to the production of the vessels, e.g. pinching, coil-building, forming with the use of paddle and anvil, wheel-finishing. Based on these observations G. Kordatzaki will reproduce some of these vessels. The marks on the experimental pots will then be compared with those on the ancient pots/ sherds in order to check their consistency.

A small storage jar that was found in the earliest Bronze Age layer (EH III/MH I) contained $36.6 \mathrm{~kg}$ of pebbles that do not originate from the acropolis, i.e. the place where they were found. To find out more about the possible purpose of this find, an application to conduct Organic Residue Analysis (ORA) was submitted to the Greek Ministry of Culture and Sport.

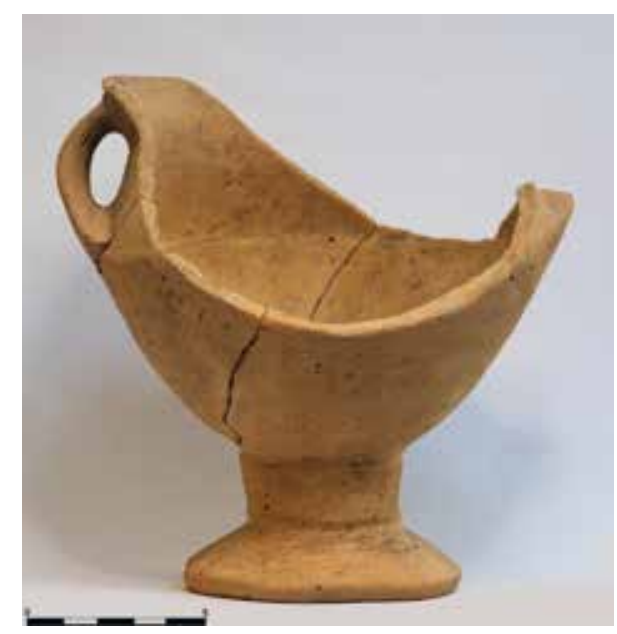

Fig. 62 Middle Helladic/Late Helladic I goblet from the settlement at Archaia Pheneos in ancient Arcadia (photo: J. Kraschitzer) 
After official permission was received, some of the fragments of the pithos, some soil adhering to the pebbles and some of the pebbles themselves were taken as samples on 23 August 2018. ORA will be carried out by Cynthianne Debono Spiteri (University of Tübingen).

In November Michaela Zavadil presented the first results of the pottery evaluation in a lecture at the Austrian Archaeological Institute, Athens Branch, entitled "Archaia Pheneos: A Middle Helladic Settlement in Arcadia".

Funding: INSTAP, University of Graz, OREA

Cooperation partners: K. Kissas (Ephorate of Antiquities of the Corinthia); P. Scherrer (University of Graz)

\section{Midea}

Michaela Zavadil spent two months at the Austrian Archaeological Institute, Athens Branch, as part of a Research Fellowship with the Austrian Academy of Sciences, where she worked on the publication of the EH III and MH pottery found in trenches A and Aa on the acropolis of Midea (Argolid). Most of the pottery dates to the transition from late EH III (Lerna IV:3) to MH I, and comes from a partly preserved floor level situated in the southern part of the excavated area. Fragments dating to later phases of the Middle Bronze Age are quite rare and mainly come from mixed contexts.

\section{Technological transition and social changes: Middle Helladic pottery analyses in the Peloponnese, Greece}

Michaela Zavadil submitted a larger project to the Austrian Science Fund, which was designed together with Evangelia Kiriatzi and Georgia Kordatzaki (Fitch Laboratory of the British School at Athens). The project is dedicated to an integrated archaeological and scientific study of $710 \mathrm{MH}$ pottery fragments from seven sites in the Peloponnese (Korakou, Gonia [Corinthia], Tiryns [Argolid], Asea-Palaiokastro [Arcadia]), Ay. Stephanos [Laconia], Nichoria [Messenia], Pisa [Elis]). This envisages the study of Middle Bronze Age ceramic production in two stages. Adopting a bottom-up approach, the team plans to move from the site to a regional level in order to gain a better understanding of the entire region. The scientific methods applied (petrography, wavelength dispersive x-ray fluorescence spectroscopy, neutron activation analysis and scanning electron microscopy) will serve various purposes and will contribute to clarifying questions of provenance and technology.

\section{Kakovatos and Triphylia in the $2^{\text {nd }}$ Millennium BCE}

\section{PI: Birgitta Eder; project staff: Jasmin Huber, Georgia Kordatzaki}

Kakovatos in Triphylia (western Peloponnese) with its three prominent tholos tombs and the contemporary habitation site forms the centre of this project, which is dedicated to the integrated evaluation of the recent excavations (2010-2011) of the settlement remains and the (re)publication of the old finds from the tombs. Moreover, it takes into consideration the regional dimension and aims at understanding the rise and demise of the site of Kakovatos within the micro-region of northern Triphylia. Therefore, the systematic and integrated analysis of the Mycenaean pottery from three neighbouring sites in terms of production, consumption and circulation forms another key aspect of the larger project.

The archaeological evaluation of the pottery from Kakovatos, Kleidi-Samikon, Epitalion and Aghios Dimitrios continued throughout the year. A meeting of Birgitta Eder, Jasmin Huber, Evangelia Kiriatzi and Georgia Kordatzaki in Athens was dedicated to the joint archaeological and petrographic discussion and evaluation of the pottery samples in order to approach questions of diachronic developments in the regional pottery production.

The typological and quantitative analysis of the Early Mycenaean ceramic material shows that the inhabitants of Triphylia adopted Mycenaean practices of pottery production from early on. All 


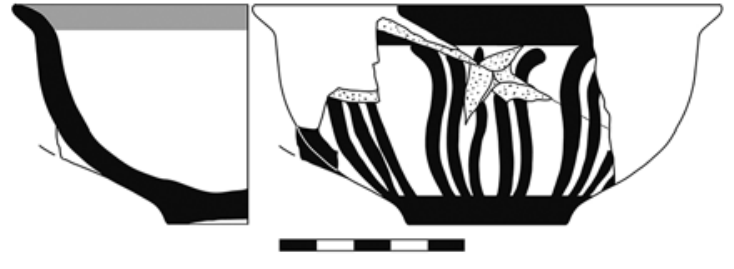

Fig. 63 LH IIB cup decorated with groups of vertical stems from Kleidi-Samikon (graphics: J. Huber, (C OREA) studied sites produced a broad range of locally produced LH IIA-IIIA1 Mycenaean wheelmade shapes. Moreover, Early Mycenaean Triphylia apparently participated in supra-regional networks. Imports from Crete, the south-east Aegean, Kythera, Aegina and the Argolid provide clear evidence for the existence of relations with other regions.

Apart from imported goods, shared pottery styles and technical features indicate social relations and can even mark shared social practices. Certain features of the local Triphylian production suggest connections to the southern Peloponnese, e. g. shallow cups with framed spirals and monochrome painted interior (Kakovatos, Epitalion, Kleidi-Samikon) and spinning bowls (Kakovatos). Other local features point to the northern Peloponnese and Central Greece. Wishbone handles from Kleidi-Samikon and Epitalion as well as fringed curved motifs find their closest counterparts in the northern Peloponnese and further north. The presence of certain Mycenaean lustrous painted motifs consisting of groups of vertical stems refers to the same northern network. It occurs on a shallow cup from Kleidi-Samikon (Fig. 63). This kind of decoration is most common in Corinthia. While further examples come from Attica, Kea, Boeotia, Chalkis on Euboea, Aetolo-Akarnania, Central Greece and Thessaly, this motif is almost absent in the southern Peloponnese. Thus, the Triphylian connections with the southern Peloponnese, especially Messenia and indirectly with Crete, are mirrored in the predilection for specific motifs, shapes and modes of decoration. However, the material of Kleidi, in particular, suggests that Triphylia apparently lay at the interface of culturally different regions.

As part of the archaeometric analysis and evaluation of the pottery, an extensive geological prospection and sampling took place that aimed at exploring the accessible raw materials in Triphylia. Evangelia Kiriatzi and Georgia Kordatzaki collected 24 geological samples from 15 different sites that reflect the spectrum of the main geological formations available. After processing the samples into briquettes, thin-sections enabled the systematic petrographic examination and the chemical analysis through WD-XRF. This approach provides the basis for comparisons of the geological samples with the pottery fabrics to check their compositional and textural similarities. That allows assumptions about the raw materials that might have been exploited for the local pottery production in Triphylia in prehistoric times.

Funding: FWF; INSTAP

Main cooperations: Ephorate of Antiquities of Elis at Olympia, P. Moutzouridis, K. Nikolentzos (Greek Ministry of Culture and Sports); Fitch Laboratory of the British School at Athens (E. Kiriatzi); H. Mommsen (University of Bonn)

\section{Kleidi-Samikon - Investigations of the Archaeological Landscape}

\section{PI: Birgitta Eder; technical staff: Mario Börner}

The site of Kleidi consists of a group of three small hills and lies to the west of and below the Classical-Hellenistic fortress of Samikon and close to the modern village of Kato Samiko. It is known as a Bronze Age settlement on the west coast of the Peloponnese. In March 2017 a cooperation project between the Ephorate of Antiquities in Elis, directed by Erofili-Iris Kolia and Birgitta Eder, was devoted to the systematic survey of the terrain around Kleidi in order to map the morphology of the hills and the existing building remains and to provide information on the character of the Bronze Age settlement and landscape use in historical times.

In this context, 2017 and 2018 geo-archaeological investigations were carried out by the team of the University of Mainz under the direction of Andreas Vött for a better understanding of the palaeo-environment. Site prospection based on electrical resistivity tomography (ERT) and vibracoring was carried out to detect and analyse subsurface stratigraphies in the area east and north of the northern hillock. 


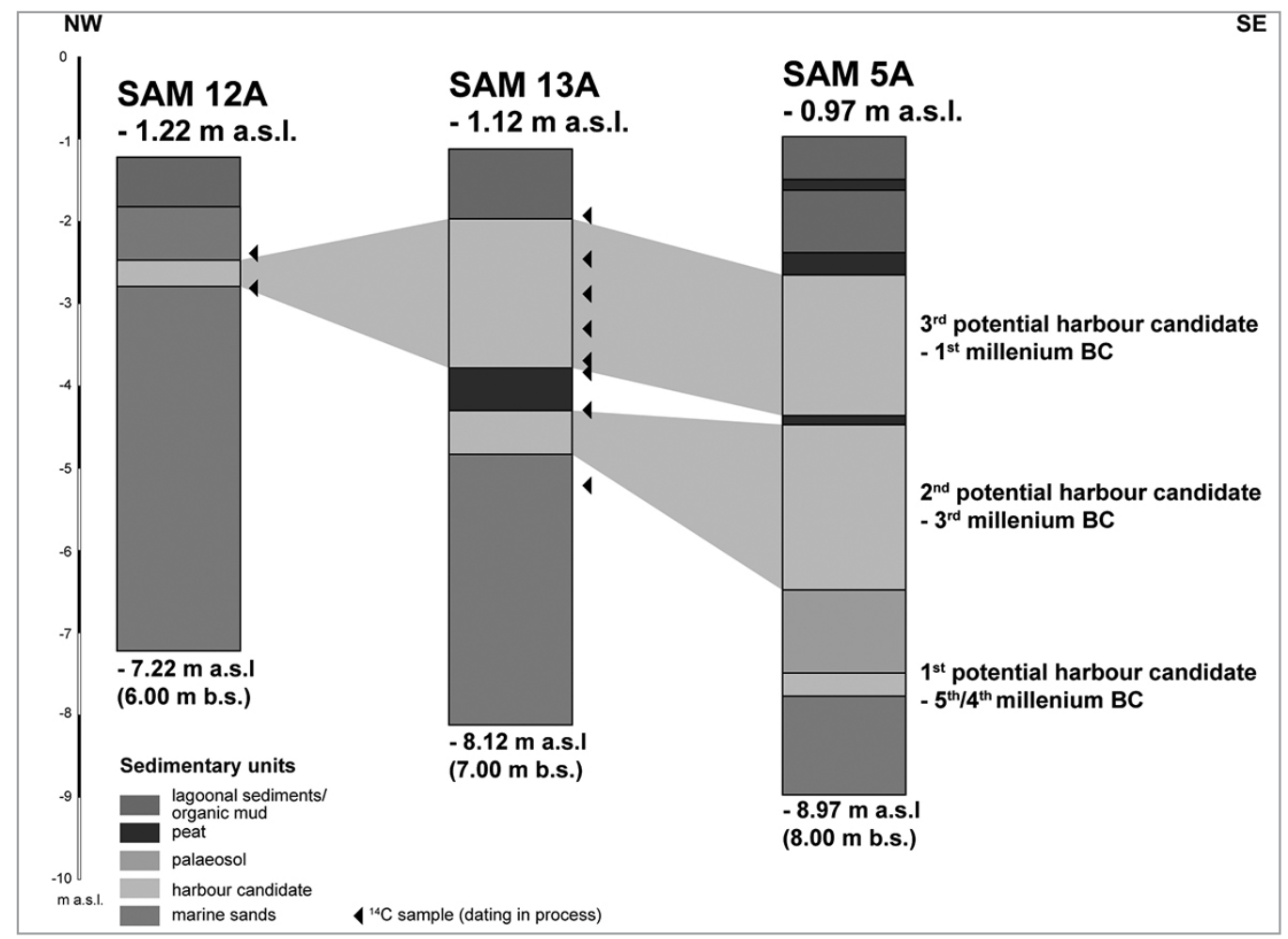

Fig. 64 Stratigraphic cross-section along the vibracoring transect near Kleidi based on sediment core data (C A. Vött and team, Institute for Geography, University of Mainz)

The sedimentary record at three different vibracoring sites revealed sections of fine-grained sediments associated with a quiescent water body that is generally suitable for a harbour basin. Moreover, sediments of harbour candidates were found in consistent stratigraphic positions at all coring sites (harbour candidate deposits I: present at all vibracoring sites; harbour candidate deposits II: present at vibracoring sites SAM 5A and SAM 13A) (Fig. 64). Only deposits of harbour candidate III were not detected in sediment cores SAM 12A and SAM 13A. With regard to changing sedimentary conditions at all investigated sites, further sedimentary analyses and ${ }^{14} \mathrm{C}$ dating of selected samples are currently in progress.

Cooperation: E.I. Kolia (Ephorate of Antiquities of Elis); A. Vött and team (Institute for Geography, University of Mainz)

\section{LH IIIC settlement of Aigeira in Achaia}

PI: Eva Alram-Stern; project staff: Mario Börner; pottery in situ: Sigrid Deger-Jalkotzy

Excavations from 1975 until 1980 at Aigeira on the southern coast of the Corinthian Gulf in the ancient region of Achaia took place under the auspices of the Austrian Archaeological Institute (directed by W. Alzinger) and revealed an important Mycenaean settlement of the post-palatial period of the $12^{\text {th }}$ and early $11^{\text {th }}$ century BCE on the acropolis. In cooperation with M. Börner, E. Alram-Stern has prepared the publication of the stratigraphy and architecture. The stratigraphic and contextual analysis of the excavation records forms the basis for the reconstruction of the social and economic organisation of the settlement. The monograph will be submitted to print in 2019.

In settlement phase Ib two house complexes north and south of an alley were identified. In the north-western complex a cluster of two independent households was reconstructed, which were probably based on family structures as they are characteristic of the post-palatial Mycenaean period. The goods that were stored in special storage rooms (Fig. 65) and produced in 
ovens and a kiln were most probably not only intended for the inhabitants of the households, but also for people connected to them like shepherds, craftspersons and the population integrated into the regional exchange systems. Consumption of food and drink in terms of feasting argues for a certain political importance of the households. The higher social status of the inhabitants of the acropolis is underlined by the ritual room in the south-western part of the plateau. Possibly the inhabitants of the acropolis are distinguished from the inhabitants of the lower terraces by the topography of the plateau. During settlement phase IIb the fortification wall, which was constructed communally by the inhabitants, served to stress this demarcation.

In LH IIIC Aigeira belonged to those settlements, which were characterised by a stratified society based on families and kinship. In this sense, they were the seats of local rulers, who were the heads of such local groups. The end of the palatial system was probably responsible for the reorganisation of society on the regional level too that led to new foundations, of which the acropolis of Aigeira may be a characteristic example.

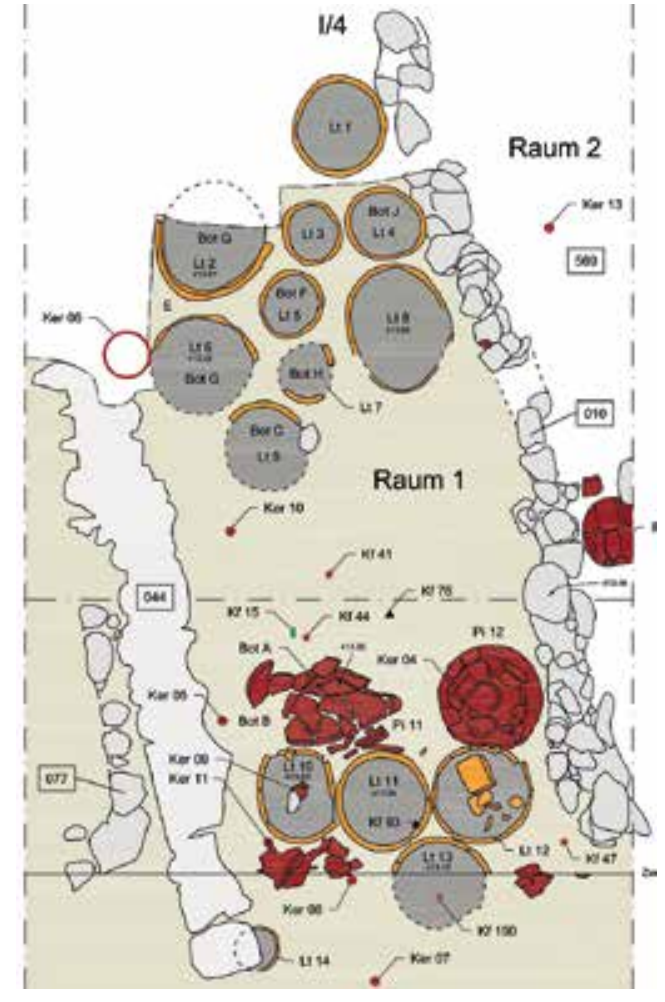

Fig. 65 Storage room of House 3 in the north-western part of the settlement on the acropolis of Aigeira in Achaia (after E. Alram-Stern, in preparation; graphics: M. Börner)

\section{The Transformation of the Mycenaean World}

The transition from the Bronze Age to the Iron Age $\left(12^{\text {th }}-9^{\text {th }}\right.$ century BCE) was an important transformative period, because major changes in the political and economic conditions led to the emergence of new social structures and political geographies in the Aegean. Since current research is often accessible only in scattered and specialised journals and publications, recent years have seen the organisation and compilation of major handbooks on the period. Birgitta Eder has written and continues to contribute general surveys of the period to several of these publications that will make Early Iron Age studies much more easily accessible to a wider group of scholars. In 2018, Birgitta Eder wrote the chapter "Homeric Burial Practices" for the Cambridge Guide to Homer, which was edited by Susanne Lupack, Corinne Pache, Casey Due, and Robert Lamberton and is due to appear late in 2019. In addition, Birgitta Eder has given several lectures on the early history of the sanctuary of Olympia and the emergence of the Greek sanctuaries in the Late Bronze Age/Early Iron Age transition.

\section{(Social) Place and Space in Early Mycenaean Greece}

Birgitta Eder and Michaela Zavadil have been editing almost 30 contributions to the international conference on "(Social) Place and Space in Early Mycenaean Greece" that was held at the Austrian Archaeological Institute in Athens (http://www.orea.oeaw.ac.at/place-and-space.html) in October 2016. The large number of rich papers, some of which are of considerable length, promises to turn the publication of the conference into a quite substantial publication on the period. The book will be part of the publications of the OREA Institute and will be submitted in 2019. 


\section{Highlights 2018}

- B. Eder spent January through March 2018 as part of a Visiting Research Fellowship at Merton College, Oxford. During this time she completed and submitted her habilitation thesis. Her host was Prof. I. Lemos, with whom she shares common interests in the Early Iron Age history of Greece. Her stay was accompanied by the seminar series on "New Discoveries and Approaches in the Archaeology of Early Greece" during Hilary term, and Birgitta Eder delivered a lecture on "The Political Geography of a Mycenaean Region: Kakovatos and Triphylia". She also gave an additional lecture on "Olympia - the Beginnings of the Sanctuary between the Mycenaean and Greek Worlds" for the Greek Archaeology Group \& Prehistoric and Early Greece Graduate Seminar, School of Archaeology, Oxford.

- Birgitta Eder and Jasmin Huber participated in the third international conference on "The Periphery of the Mycenaean World: Recent discoveries and research results", which took place 18-21 May 2018 in Lamia. While Birgitta Eder presented a paper on "The Mycenaean Periphery: Questions of Definition", Jasmin Huber took the opportunity to present the results of her current research in the framework of her dissertation project on "Triphylia: A Mycenaean Periphery? What the analysis of pottery can tell".

- Birgitta Eder submitted her habilitation thesis with the title "Elis und Olympia. Die Genese zweier Zentren einer Landschaft" to the Technical University of Darmstadt, where it was accepted after a public lecture in July 2018.

- Michaela Zavadil presented the paper "Remembering old graves? Jar burials in the Mycenaean period" at the international biennial Aegaeum conference that took place in Venice and Udine on 17-21 April, 2018 and was dedicated to the topic of MNHMH. Past and Memory in the Aegean Bronze Age.

- Together with Dieter Hertel, Sigrid Deger-Jalkotzy published the fine and handy monograph on the Mycenaean World, Das mykenische Griechenland: Geschichte, Kultur, Stätten, that appeared in German in the C.H. Beck publishing house in autumn 2018.

- As part of her research fellowship with the Austrian Academy of Sciences at the Austrian Archaeological Institute, Athens, M. Zavadil spent two months in Athens working on the publication of the MH pottery found in trenches A and Aa on the acropolis of Midea (Argolid). On 20 November she delivered the evening lecture at the Austrian Archaeological Institute on "Archaia Pheneos: A Middle Helladic Settlement in Arcadia".

- On 30 November, 2018 Birgitta Eder joined the opening of the largest ever exhibition in Germany on the Mycenaean world under the title Mycenae - the mythical world of Agamemnon at the Badisches Landesmuseum in Karlsruhe. The Karlsruhe exhibition presents many great archaeological finds from Mycenaean Greece that are also discussed in a corresponding lavish catalogue. Among these are a rich series of finds from Kakovatos including jewellery of lapis lazuli, amethyst and amber as well as gold foil ornaments, a sword and two palatial amphorae. Birgitta Eder and Jasmin Huber wrote entries on the site and finds from Kakovatos for the catalogue. The Karlsruhe exhibition was accompanied by a conference in Heidelberg on "Ambivalent Times: The Mycenaean Palatial Period between Splendour and Demise", 1-3 December, 2018, where Birgitta Eder delivered the paper "Beyond the Mycenaean palaces: The extent and limits of palatial influence and control".

Birgitta Eder - Eva Alram-Stern - Jasmin Huber - Andreas Vött - Michaela Zavadil 


\section{Urnfield Culture Networks \\ (Research group leader: Mario Gavranović)}

\section{Objectives}

The research group Urnfield Culture Networks is focused on the long-term investigation of the Bronze Age in central and south-east Europe with a special emphasis on the emergence and expansion of the Urnfield Culture and mutual interactions with neighbouring, contemporary cultural phenomena.

Special attention is given to burial customs, socio-economic phenomena, as well as religion and ritual and their impact on the cultural and social developments. Selected research questions include: resources, technologies and power, cremation burials and cultural transmission in a diachronic perspective, as well as social identities and mobility as expressed through cultural and biological parameters.

The social, economic and religious aspects of the Urnfield Culture are explored by the team members in various regional studies in Austria and in the Balkans and are embedded in the European context of the Bronze Age. Essential for the successful cooperation and implementation is the integration of local researchers and specialists in a common network. The research group strongly supports medium- and long-term inclusion of young talent at doctoral and early postdoc level.

The utilisation and evaluation of large data sets from excavations that have been conducted over many years in Austrian sites, such as the settlements of Thunau am Kamp, Stillfried an der March, as well as the cemeteries Franzhausen-Kokoron and Inzersdorf ob der Traisen are of central importance for the research in Austria as one of the core zones of Urnfield culture. The investigations in south-east Europe (Croatia, Bosnia-Herzegovina, Serbia and Macedonia), conducted in the frame of the "Balkan initiative" of the OREA Institute, represent another important and complementary part of the research programme. Open access digital initiatives, interactive publications, international workshops and conferences organised by the members of the UCN in Austria and abroad round out the activities of the team.

\section{Current research}

\section{South Connections: Spreading of the Urnfield Phenomena and Mobility in Bronze Age}

Team: Mario Gavranović, Michaela Lochner

This project aims to explore specific interregional connections between the regions of Lower Austria and northern Croatia during the older stage of the Urnfield culture (Baierdorf-Velatice complex) with a special emphasis on chronology, burial customs and changes in the material culture. The focus of the bilateral project will be on the comparison of the advanced typological sequence of the material culture in correlation with absolute dates.

In March 2018 the Austrian and Croatian team members visited the museums in Zagreb, Križevci and Slatina. The goal was to compare the detailed typological and chronological sequence of pottery shapes and decorations related to the early phase of the Urnfield Culture from important sites such as Zagreb-Vrapče (Archaeological Museum Zagreb), Kalnik (City Museum Križevci) and Veliko Polje (Museum Slatina).

In May 2018, the Croatian project partners visited Austria and the OREA Institute. The team members first stopped at Asparn (MAMUZ), then went to Eggenburg (Krahuletz Museum) and Horn (Höbarthmusuem), followed by Nußdorf ob der Traisen (Urzeitmuseum) and finally Stillfried an der March (Zentrum der Urzeit). Thanks to free access to the museum depots, some of the crucial finds of the Baierdorf-Velatice stage, including objects from urn graveyards in Baierdorf and Horn, were revisited and studied. As part of the cooperation, project members also developed 
an outline of the joint actions for the following months involving archaeo-metallurgical analyses of some distinctive bronze types, both from Croatia and Lower Austria.

Cooperation partners: Snježana Karavanić, Daria Ložnjak Dizdar (Institute for Archaeology, Zagreb, Croatia)

Funding: Austrian Agency for International Cooperation in Education and Research (OEAD), Scientific and Technological Cooperation Programme (WTZ), Federal Ministry of Science, Research and Economy (1.1 2018 - 31.12. 2019).

\section{Securing resources, power and cult in Stillfried?}

PI: Michaela Lochner, team: Monika Griebl (Key Researcher), Benedikt Biederer

The project is devoted to the question of whether or not the central site at Stillfried had the function of a supra-regional grain storage space accompanied by elaborate rituals. The remarkably high density of cone-shaped (storage) pits with similar filling patterns triggered these considerations; in particular, the depositions of wild and domesticated animals in these pits are exceptional.

Throughout the first half of 2018 material recording and evaluation of the single feature were successfully completed and work on the final publication resulting in a monograph was intensified. Recent analyses succeeded in identifying black ring-shaped objects found in a storage pit (No. 5400) as a cereal product (barely - wheat) in cooperation with Andreas G. Heiss (University of Natural Resources and Life Sciences, Vienna). Furthermore, strontium isotope analyses of eleven human individuals from the collective grave within the fortified area of Stillfried have been undertaken. Additionally, fifteen samples from different areas of the site (Wagneracker, Küssleracker und Bügeleisen) were ${ }^{14} \mathrm{C}$ dated in the Poznan laboratory (Poland). With this last step, the total number of radiocarbon dates gained at Stillfried is 60 .

In May 2018 the members of the project initiated a round table with several renowned experts in botany, archaeobotany and archaeology (Ulf Baum, Michaela Popovtschak, Clemens Eibner, Martin Penz and Peter Trebsche) with the aim of discussing all relevant project questions regarding the storage of supplies. Monika Griebel and Benedikt Biederer also took part in the organization of Urnfield Culture Dialogues ("UK-Gespräche"), where they presented the latest project results. Subsequently, they initiated and organized an excursion to Stillfried for all workshop participants with a detailed guided tour of the site and in the nearby museum of Stillfried (Fig. 66).

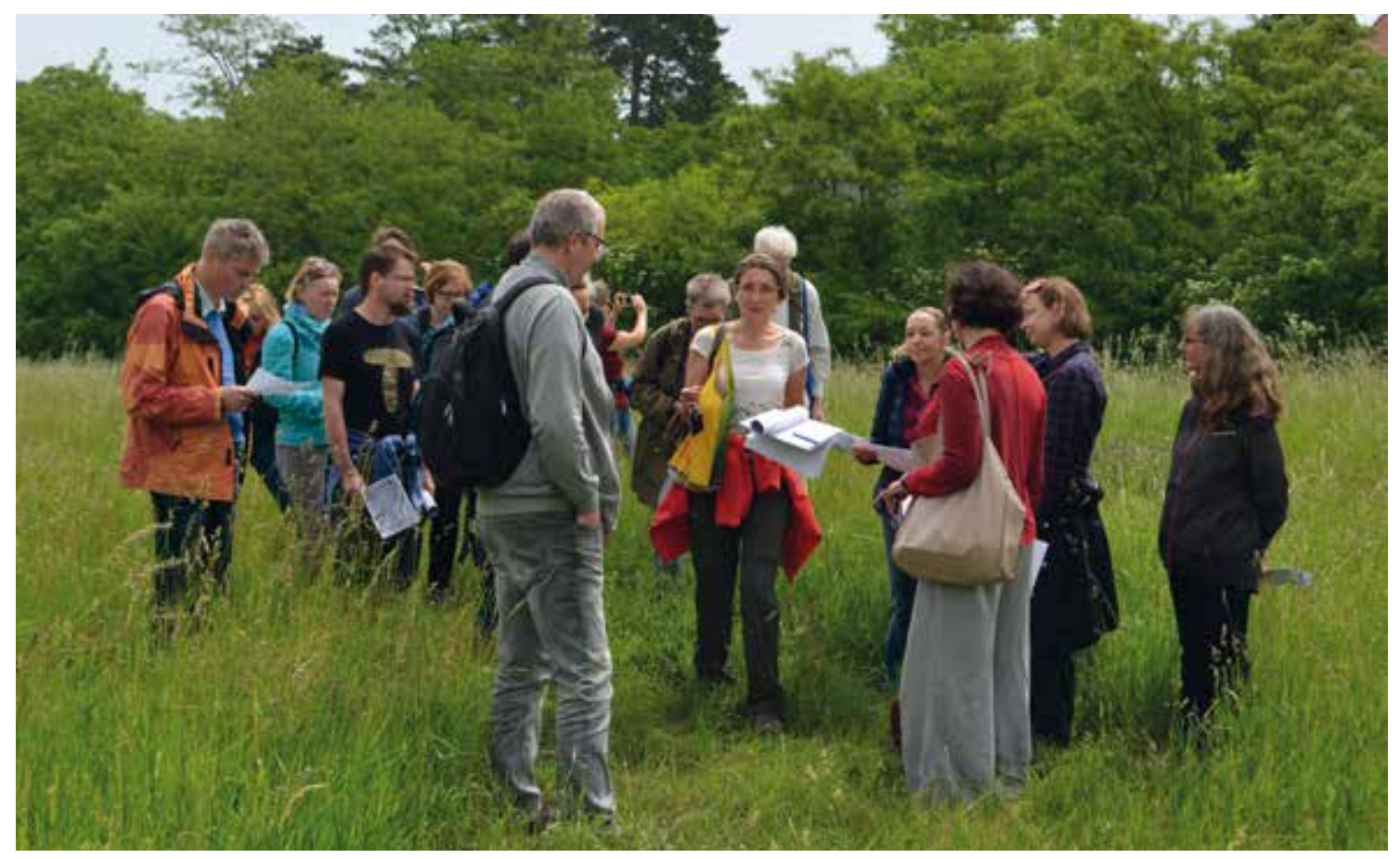

Fig. 66 UC Dialogues, Stillfried exursion (photo: M. Gavranović, (C OREA) 
After the successful completion of his master's thesis, Benedikt Biederer started with his $\mathrm{PhD}$ thesis (University of Vienna) based on the results of the Stillfried project. He will investigate food storage patterns in central Europe from the Neolithic to the Bronze Age. His $\mathrm{PhD}$ thesis will also include an experimental part with three storage pits, that he and project members set up in loess soil (in summer 2018) in Lower Austria. The pits were filled with crops and closed using different techniques and will be opened at different stages. In December 2018, the PhD proposal by Benedict Biederer was awarded the DOC Stipendium of the Austrian Academy of Sciences (three years).

Funding: FWF stand-alone project P 28005 (1.11.2015-31.3.2019)

\section{The Early Urnfield Culture cemetery of Inzersdorf ob der Traisen, Lower Austria}

Team: Michaela Lochner, Mario Gavranović, Katharina Rebay-Salisbury, Michaela Fritzl

Despite falling victim to grave robbery in Antiquity, the 273 urn burials and scattered cremations of the cemetery were found exceptionally well equipped with grave goods. The analysis and interpretation of the cemetery is being carried out by several young scientists in a joint action by the research groups Urnfield Culture Networks and Prehistoric Identities.

In 2018, Nicole Mittermair, a master's student associated with the UCN group, finished the first metallographic analyses of selected bronze finds (35 items) from graves (knifes, razors and pins) that will be an integral part of her master's thesis (submission summer 2019). The analyses were conducted at the archaeo-metallurgical laboratory of the Vienna Institute for Archaeological Science (VIAS) under the guidance of Mathias Mehofer.

The comprehensive analysis of the Inzersdorf cemetery, with a focus on possible non-local elements both in material culture and biological parameters (isotopes), will be the focus of the $\mathrm{PhD}$ thesis of Michaela Fritzl, which she started in 2018 within the research group Prehistoric Identities.

\section{The Late Urnfield Culture cemetery of Franzhausen-Kokoron, Lower Austria}

Team: Michaela Lochner, Mario Gavranović

The extensive analysis and interpretation of the 403 cremation graves with approximately 1600 individual objects includes a catalogue and photographic material (overview plan, photographs and drawings of finds and contexts), which is available as a digital, interactive open access publication via the Austrian Academy of Sciences Press. In 2018 several hundred graves were also integrated into the Cremation Bronze Age Burials (CBAB) database and can be retrieved by various queries.

As part of Nicole Mittermair's master's thesis, 40 selected bronze finds from the graveyard in Franzhausen (knifes, razors and pins) were analysed and evaluated in terms of metallography (use traces, abrasion, details of casting, decoration details, metal structure). The results will be presented in the master's thesis and will also provide a solid basis for further analytical steps (chemical composition, isotopes).

\section{Visualizing the unknown Balkans}

Team: Barbara Horejs, Mario Gavranović, Irene Petschko, Bogdana Milić

This project represents a joint action by the research groups Prehistoric Phenomena and Urnfield Culture Networks. Based on five case studies by the OREA Institute in the Balkans, the project aims to publish the results of the archaeological research with accessible visual concepts which can be readily understood by the broader public. The UCN research group is involved in three case study areas, including eastern Serbia (Bronze Age sites with evidence of metallurgical activities), central Bosnia (Bronze Age hill top settlements) and north-eastern Bosnia (large tumuli in lowlands).

The first activity in 2018 (October) involved field work on the sites Trnjane (settlement) and Hajdučka česma (cremation burial site) in eastern Serbia. The excavations and surveys yielded a 


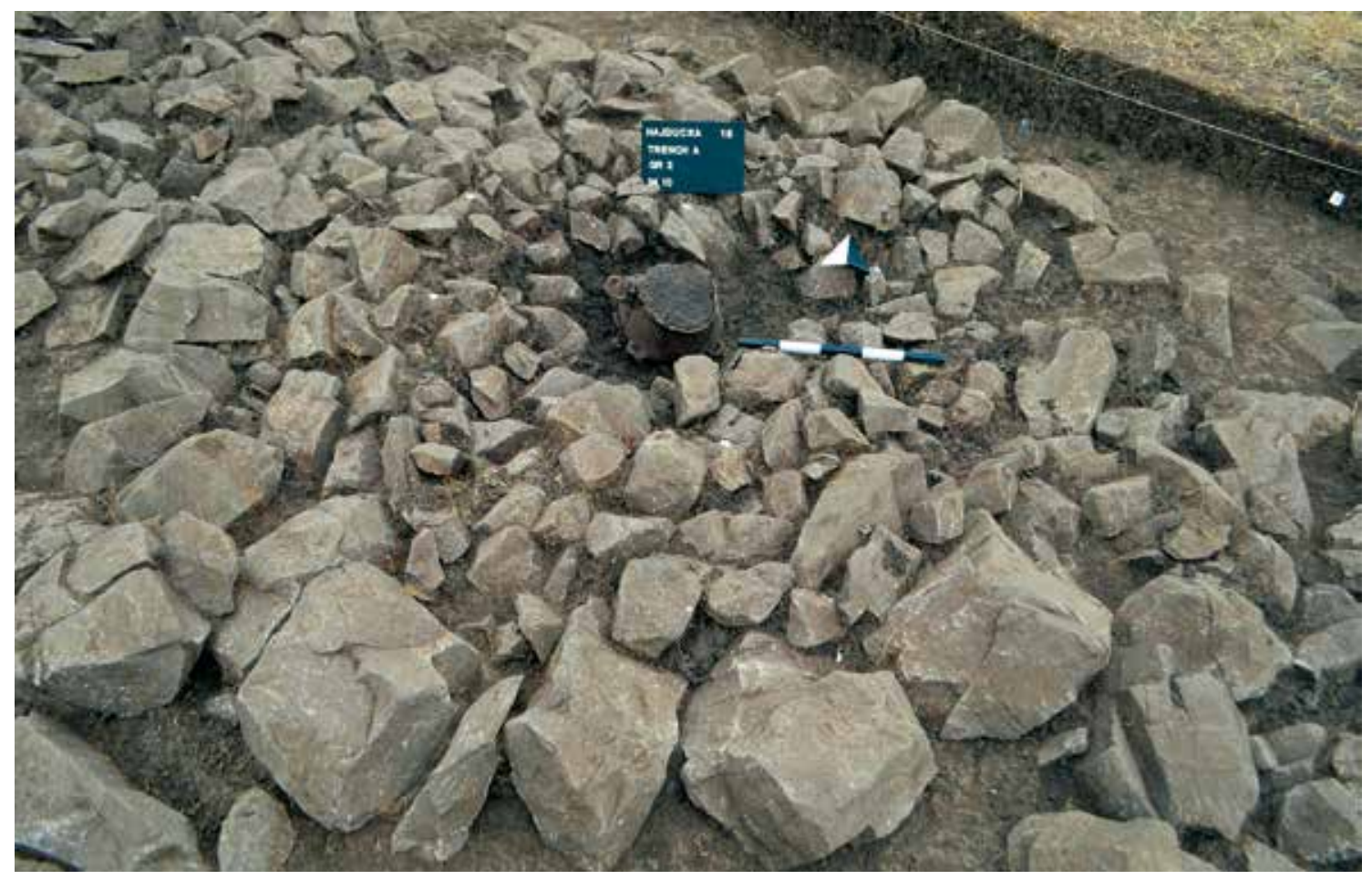

Fig. 67 Hajdučka česma, Eastern Serbia, grave no. 2 (photo: M. Gavranović, (C) OREA)

great number of new primary data regarding the chronology and the structure of Bronze Age societies in this region. Of special interest were the detection of metallurgical activities in the Trnjane settlement (slags and ores) and the discovery of the large cremation burial site in Hajdučka česma (Fig. 67). Judging by the previously conducted geomagnetic screening and first excavations in 2018 , this graveyard contains around 80 circular stone constructions with urns. For the purpose of visualization, all revealed structures were documented using 3D techniques accompanied by drone photographs and movies of the sites and surrounding landscape.

In early November 2018 the team members were engaged in geomagnetic prospection of the Bronze Age hill top settlements Kopilo, Ravna and Gradac in the vicinity of Zenica in central Bosnia (Fig. 68). All three sites investigated are in direct visual contact with one another, pointing

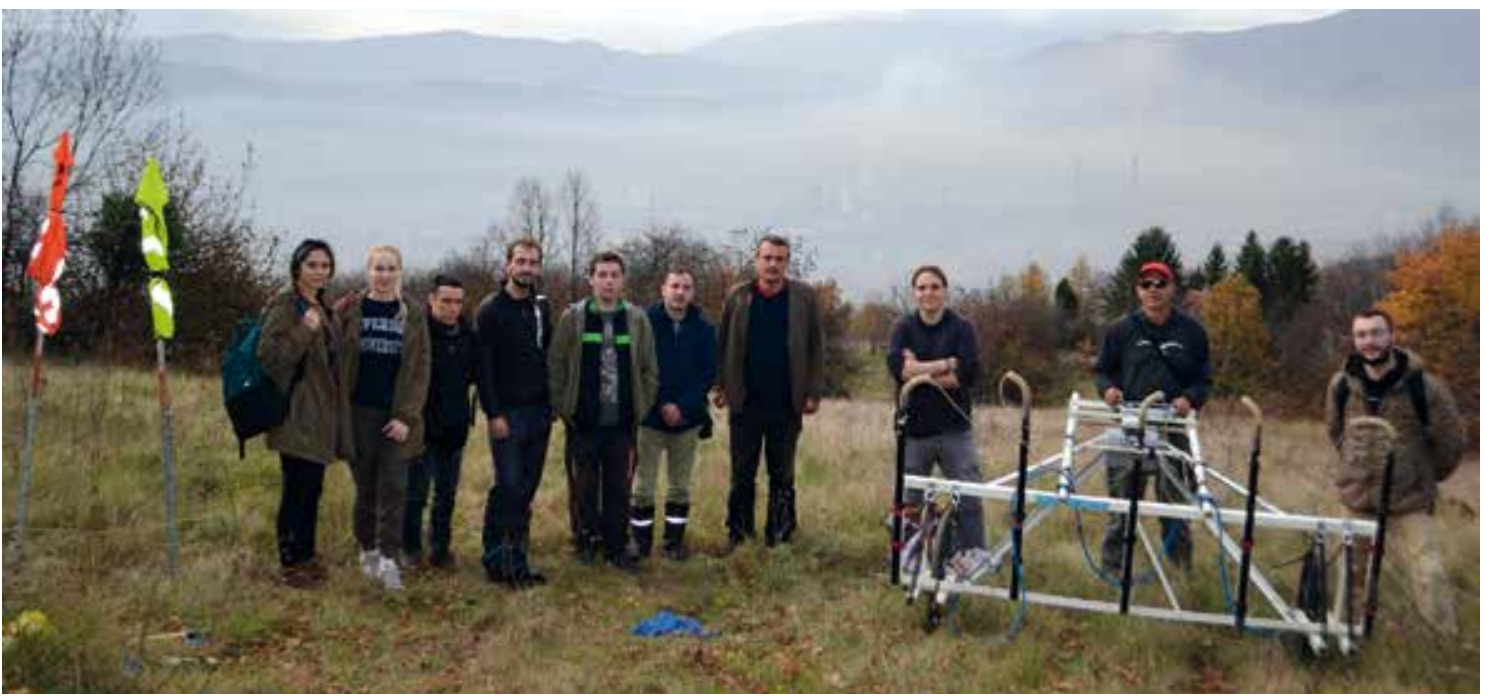

Fig. 68 Zenica, Bosnia-Herzegowina, geomagnetic prospection (photo: W. Hypiak, (C) OREA) 
to straight communication. The first geomagnetic results indicate comparable activity zones in all three sites (objects, ovens, pits), mostly located on the terraces along the fortification, whilst the central settlement areas appear to be less frequently used. Future field work in 2019 will contribute to embedding these sites in a local and regional background.

The next field action was focused on large tumuli near Bijeljina in north-eastern Bosnia. After the geomagnetic screening indicated the presence of tumuli structures (enclosures with prehistoric structures), the excavation in November 2018 at the site Novo Selo revealed the existence of a Bronze Age burial site with both inhumation and cremation urn graves. A skeleton was found in a crouched position and was deposited on a pebble platform (Fig. 45). Although only one quarter of the tumulus could be completely excavated, the data obtained provide sufficient evidence for the visual reconstruction of a burial place with a peculiar enclosure in a keyhole shape and with clearly visible remains of a vegetative substrate that was intentionally deposited below the graves.

Final activities in December 2018 involved airborne prospection (LiDAR) of the sites in central Bosnia and eastern Serbia. Due to the mountainous terrain, a helicopter was used. The airborne screening covered around $10 \mathrm{~km}^{2}$ of heavily forested surroundings at each site area.

Funding: Innovation Fund of the Austrian Academy of Sciences

\section{Bronze Age metallurgy in the western and central Balkans}

PI: Mario Gavranović, key researcher: Mathias Mehofer (Vienna Institute for Archaeological Science)

The project aims to investigate metal production and the metal supply and exchange networks of the Bronze Age societies in the Balkans representing the intermediary region between central Europe (Urnfield culture) and the Mediterranean world. By using various chemical-analytical and archaeological methods, the project seeks to develop a new idea about the importance of the local metallurgy and ore resources.

In 2018 the team members undertook several efforts with the aim of significantly extending the existing data sets. Thanks to the cooperation agreements between OREA and museums in Sombor (City Museum), Novi Sad (Museum of Vojvodina) and Požarevac (National Museum) in Serbia, Mario Gavranović and Mathias Mehofer were able to sample a further 200 Bronze Age artefacts (finished and semi-finished products, ingots, slags and ores) during the research trip in April and May 2018 (Fig. 69). Furthermore, they studied the finds from the Balkans stored at the Natural History Museum in Vienna and selected 95 relevant objects to be sampled in February

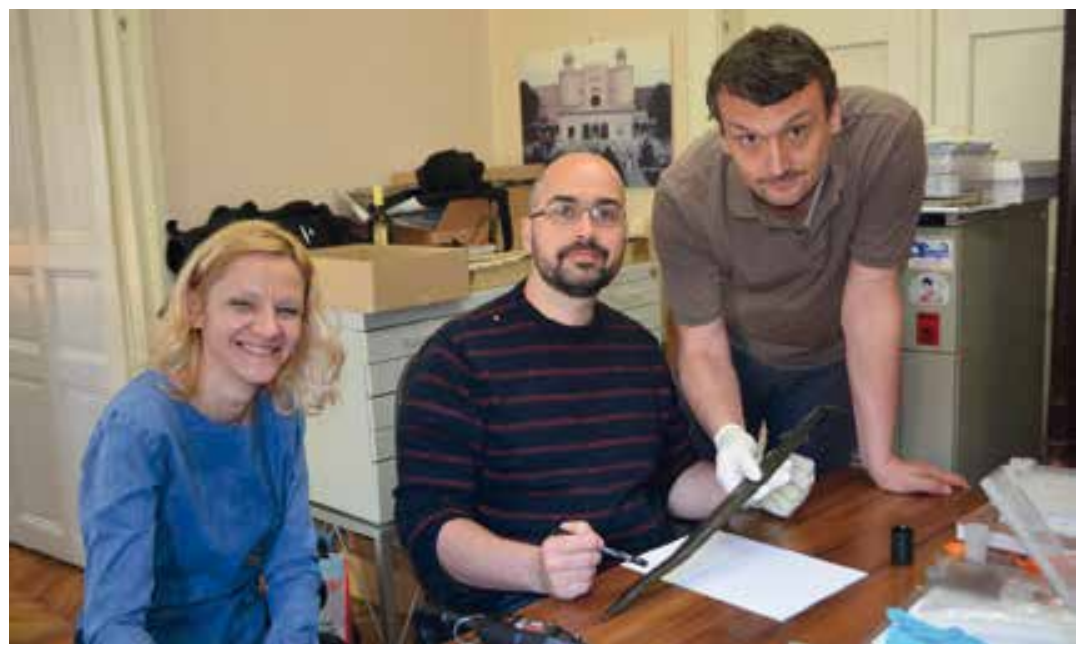

Fig. 69 Sampling of bronze finds in Sombor City Museum, Serbia, A. Putica, M. Mehofer, M. Gavranović (photo: V. Uzelac) 
2019. Together with previously conducted activities in Serbia, Bosnia-Herzegovina and Croatia, the total number of samples obtained amounts to 650 .

The first analyses of the finds from the sites with metallurgical activities in eastern Serbia such as Trnjane and Ružana clearly confirmed Bronze Age copper smelting activities with different slag types pointing to developed technology. The field work in the Trnjane site (October 2018) yielded new slag finds as well as a mass of pottery finds, stone artefacts and animal bones. The smelting of the ore was obviously performed within the settlement. Further analyses (radiocarbon, chemical composition, isotopes) are planned and will shed new light on Bronze Age copper production in this region. Together with cooperation partners from Serbia (Archaeological Institute Belgrade and the Museum of Mining and Metallurgy in Bor), the team members will conduct further field investigations in 2019.

Mario Gavranović's successful application to the Dr. Anton Oelzelt-Newin'schen Foundation in November 2018 has enabled a larger series of analyses (trace elements, lead isotope) on samples obtained from the Balkans. With the help of the funding, nearly 100 samples were sent to the Curt Engelhorn Centre of Archaeometry in Mannheim. The results will be evaluated in 2019.

In August 2018 Mario Gavranović also submitted an application for an FWF stand-alone research project with the title "New insights in Bronze Age metal producing societies". The main objective of the project is the evaluation of the already collected samples and the interpretation of results on a regional and supra-regional scale. The results are pending.

In October 2018 Mario Gavranović and Mathias Mehofer launched the seminar ("Bronze Age metallurgy in the Balkans") at the University of Vienna. The objective is to introduce previous and new research on this topic, including the achievements of the ongoing project, to advanced students.

Some aspects of the project were also presented to a broader public during the "Tag des Denkmals" at the Austrian Academy of Sciences, where around 600 visitors had the chance to learn about the process of metallurgical investigation in the Balkans and current analytic methods.

\section{Macedonian Metals}

Team: Mario Gavranović, Aleksandra Papazovska (Archaeological Museum Skopje), Mathias Mehofer (Vienna Institute for Archaeological Science)

Based on the long-term cooperation agreement between the OREA Institute and the Archaeological Museum in Skopje signed in 2018, this project represents the first joint action by the two

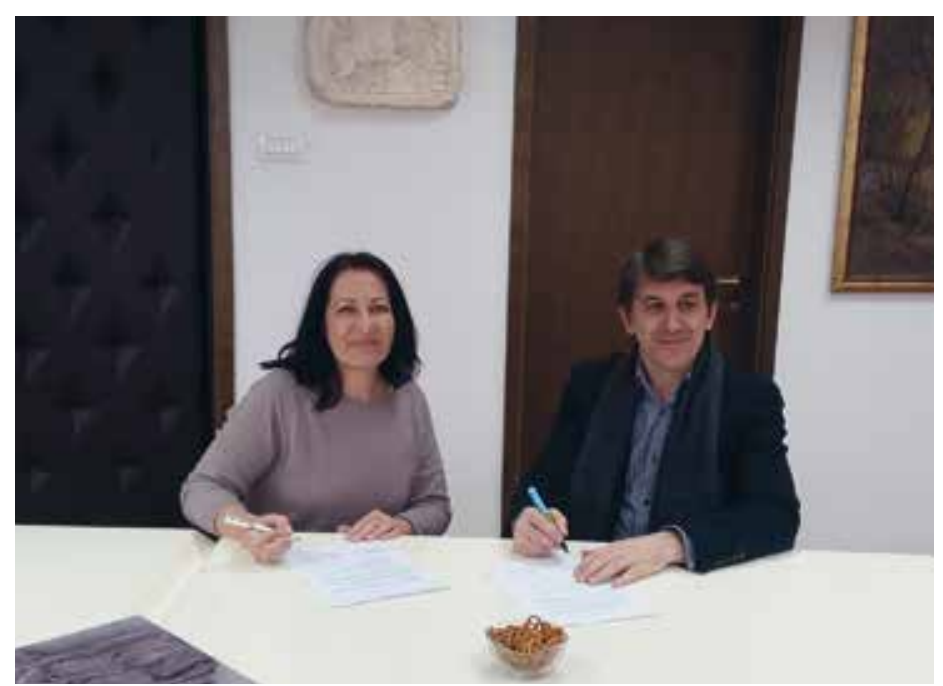

Fig. 70 Signing the cooperation agreement at the Archaeological Museum Skopje, B. Horejs and G. Sanev (photo: A. Papazovska Sanev) 
institutions (Fig. 70). The main objective is to investigate the technological and metallurgical background of Bronze and Early Iron Age metal finds from the Republic of North Macedonia by combining archaeological and analytical methods. This will help to reconstruct regional and local metallurgical networks and to identify the possible origins of the raw material copper. Furthermore, the analytic results (chemical and isotopic signature) will allow comparison with data sets from the surrounding regions in south-eastern and central Europe.

In May 2018 the team members sampled 65 metal artefacts from museums in Skopje, Veles and Gevgelija. The spectrum included typical local and regional forms from the Late Bronze Age (e. g. pins of the type Fortuna), foreign forms (Mycenaean rapier from Tetovo, socketed axes from Manastir) as well as a variety of so called "Macedonian bronzes" (pendants, belts discs) from female graves in necropolises in Milci, Lisičin Dol, Bučinci, Dedeli and Mali Dol. The first series of analyses will be presented in 2019 .

\section{Digital initiatives}

\section{- Cremation Bronze Age Burials Database (CBAB)}

Team: Mario Gavranović, Michaela Lochner

The aim is the coordinated assessment of the European phenomenon of cremation burials in the Late Bronze Age based on a shared database, a comparison of local and partial analyses of cemeteries, anthropological analyses as well as theoretical considerations of funerary rituals.

Thanks to the cooperation with the Austrian Centre for Digital Humanities (ACDH), the open access and browser-supported database app CBAB (Cremation Bronze Age Burials) was developed and completed in 2018. The process of development and code writing will be explained and presented in detail in a joint paper by ACDH and UCN team members scheduled for 2019.

After the successful test phase and first entries, the CBAB database was officially released in February 2018. To date, the database contains data on several hundred burials from sites in Austria, Slovenia, Hungary, Croatia and Serbia. The mid-term goal is to significantly increase the amount of data in order to provide the possibility for relevant queries on a larger regional scale. The first step will be to complete the data entries of large and well published burial places in Austria, starting with Franzhausen-Kokoron and Inzersdorf ob Traisen. In a second step, the $\mathrm{CBAB}$ will integrate the existing databases of Bronze Age burials, developed and used by different scholars throughout Europe, and is collaborating with the UCN research group.

\section{- OREA Dokuplattform Thunau am Kamp - a fortified hilltop settlement of the Urnfield Culture} Team: Mario Gavranović, Michael Konrad, Michaela Lochner

This project is part of the analysis of excavations carried out between 1965 and 2003 (excavations directors: Herwig Friesinger, Erik Szameit). The large number of finds from over 430 excavation trenches, excavated over the whole extent of the 20 ha complex, comprises over 100,000 individual objects. The finds have already been inventoried and categorised, a large part has been drawn and parts of the sections/plans of contexts have been digitalised.

Thanks to the cooperation with the Austrian Centre for Digital Humanities (ACDH), Archaeological Department for Prehistory in Lower Austria (Franz Pieler) and the newly established Digital Documentation Lab at OREA, the structure for online presentation of all available data was further developed and eventually finalised by the end of 2018. The first test version of the web page was launched in November 2018 as the transmission of all data into the central repository of the Austrian Academy of Sciences was successfully accomplished. The existing web page structure is currently being upgraded with new data that will then be available in the course of 2019. The goal was to create a user-friendly web page with the possibility to access large data sets that can be used both for public and scientific purposes on different levels (review, research, queries). 


\section{Conferences/workshops}

\section{- Urnfield Culture dialogues ("UK-Gespräche”)}

The UC dialogues ("Get together") is an annual workshop for researchers on the Late Bronze Age/Urnfield Culture (1300-800 BC) in Europe with different thematic and regional focuses. All meetings are organised by the research group Urnfield Culture Networks and the home institute OREA. The concept combines a one- or two-day thematic workshop, a corresponding public evening lecture and, usually, an excursion or field trip to the sites in the vicinity of Vienna.

Starting from the results of the research project "Securing resources, power and cult in Stillfried", the UC dialogues in 2018 focused on different aspects of food storage and consumption in Bronze Age central Europe.

- 16.5.2018: UK-Gespräche/Key note lecture: Immo Heske, University Göttingen: Vorratshaltung und Vorratsgefäße: Siedlungen und Nahrungsdistribution nördlich der Mittelgebirgszone von der mittleren Bronzezeit bis in die frühe Eisenzeit

- 17.5.2018: UK-Gespräche/Workshop: "Storage and Consumption/New Insights on Bronze Age storage and nourishment practices"

- 18.5.2018: UK-Gespräche/Field trip to Stillfried/Site visit and Museum Stillfried

- PEBA (Perspectives on Balkan Archaeology)

The primary aim of the PEBA initiative is to create an international platform for young academics that will refresh, further facilitate and maintain cross-border archaeological research between central and south-east Europe.

After the organisation of two international conferences, 2016 in Sarajevo (The Early Iron Age: Methods and Approaches) and in 2017 in Belgrade ("Spheres of Interaction. Contacts and Relationships between the Balkans and adjacent regions in the Bronze and Iron Ages"), the PEBA team focused on the publication of proceedings in 2018. The 2016 papers from Sarajevo were published in a special section of the peer-reviewed journal "Jahrbuch des Zentrums für Balkanfoschungen", volume 48, 2018. The proceedings of the conference in Belgrade have been submitted and will be published in a first volume of the newly established series (PEBA Conferences) in 2019. The next conference is scheduled for 2020 and will take place in Ohrid (Macedonia).

\section{Outreach activities}

- 30.9.2018: Public presentation of the project "Vizualising the unkown Balkans" in the frame of a National Monuments Day in the Austrian Academy of Sciences. Around 600 visitors, including school classes, had an opportunity to experience the results of archeological research (Mario Gavranović and Irene Petschko)

- 25.10.2018: Mario Gavranović and the cooperation partner Aleksandar Kapuran, Institute of Archeology in Belgrade, presented the results of excavation at the site Hajdučka česma for regional and state media in Serbia, including TV- Stations, Radio and Web.

- 5.11.2018: Public lecture about the perspectives of archeological research in Bosnia and Herzegovina at the Austrian Embassy in Sarajevo (Mario Gavranović, Barbara Horejs)

- 21.11.2018: Mario Gavranović and Snježana Antic, Museum of Semberija in Bijeljina, gave a extensive overview about the investigation results at the site Novo Selo near Bijeljina for a National TV Broadcaster in a Live Morning Show. They also organized a media day at the site, attended by several TV and Radio crews and journalists of regional and national newspapers. 


\section{Highlights 2018}

- Successful accomplishment of the field work campaigns in Serbia and Bosnia-Herzegovina between October and November 2018 within the project "Visualizing the unknown Balkans", including the discovery of a new cremation burial site Hajdučka česma (eastern Serbia) and the Bronze Age bi-ritual tumulus in Bijeljina (Bosnia-Herzegovina).

- Organisation of "Urnfield Culture Dialogues" (UK-Gespräche) between $16^{\text {th }}$ and $18^{\text {th }}$ May and excursion to Stillfried site.

- Start of the project "Macedonian Metals" in cooperation with the Archaeological Museum Skopje, followed by first sampling series in Museums in Skopje, Veles and Gevegelija.

- Doc grant from the Austrian Academy of Sciences for Benedikt Biederer (Project: Securing resources, power and cult in Stillfried?).

- Approval of the funding from the Dr. Anton Oelzelt-Newin'schen Foundation for the first large series of analyses within the project "Bronze Age metallurgy in the Balkans".

- Funding from the JESH (Joint Excellence in Science \& Humanities) programme of the Austrian Academy of Sciences for Daria Ložnjak Dizdar (Archaeological Institute Zagreb, Croatia). Visit to the OREA Institute 14.1.-15.3.2019.

Mario Gavranović - Monika Griebl - Benedikt Biederer 
OREA RaW Material LaB

(Lab leader: Michael Brandl)

\section{Objectives}

The OREA Raw Material Lab is an analytical facility for archaeometric analyses of archaeological materials. The primary objectives are material, technological and provenance studies of rocks and ceramics from archaeological contexts. Currently, leather technology is also represented by a Hertha Firnberg research project directed by Gabriela Ruß-Popa.

The Lab is equipped with high resolution reflected- and polarized light microscopy coupled with a state-of-the-art camera system for standardised microphoto documentation. Research collaborations with the University of Vienna and the University of Graz provide access to environmental Scanning Electron Microscopy (SEM) and Laser Ablation Inductively Coupled Plasma Mass Spectrometry (LA-ICP-MS) for trace element analyses. Additionally, one of the most relevant comparative rock collections in Europe, the Vienna Lithothec, housed by the University of Vienna, is available for provenance studies.

Lithic provenance studies are performed according to the "Multi-Layered-Chert-SourcingApproach" (MLA). This technique combines petrographic, mineralogical, geochemical and multivariate statistical analyses for the determination of the origin of raw materials used for chipped stone tool production.

Ceramic raw material and technological studies are undertaken using thin section petrographic analysis. Skin and leather are examined under reflected light stereomicroscopy.

The analyses performed in the OREA Raw Material Lab are the basis for reconstructing socio-economic developments, exchange networks, and for testing models of prehistoric resource management on local, regional and supra-regional scales.

\section{Lab team}

Michael Brandl (director, lithic analyses), Clare Burke (ceramic petrography), Gabriela Ruß-Popa (leather and skin technology)

Associated researcher: Oliver Schmitsberger (BergBauLandschaftWien project)

\section{Current research}

The OREA Raw Material Lab looks back on an eventful year in 2018. This report is structured according to the different materials studied during the reporting period in a chronological order.

\section{Lithic studies \\ (Michael Brandl)}

Technological and raw material analyses of the Early and Middle Neolithic chipped stone tool assemblage from Paliambela Kolindros in Greek Macedonia were undertaken in March by Michael Brandl and Bogdana Milić (member of the research group Prehistoric Phenomena). Raw material surveys in the vicinity of the site produced evidence for locally available cherts, radiolarites, quartz and jasper. The Early Neolithic is characterised by those local raw materials, while obsidian dominates the Middle Neolithic assemblage. The observed "microlithic" character of the Early Neolithic assemblage appears to be a result of two factors: the small size of the available local raw materials and a local tradition. However, the sample is very small and may not be representative for the overall picture, hence further studies are planned for 2019 to substantiate the dataset.

In the framework of the planned project "BergbauLandschaftWien" geo-archaeological surveys were conducted in the area of the Lainzer Tiergarten, which has now produced evidence for 15 previously unknown radiolarite quarrying and processing sites. They attest to the existence of a mining cluster of international significance in the west of Vienna. The planned project will 


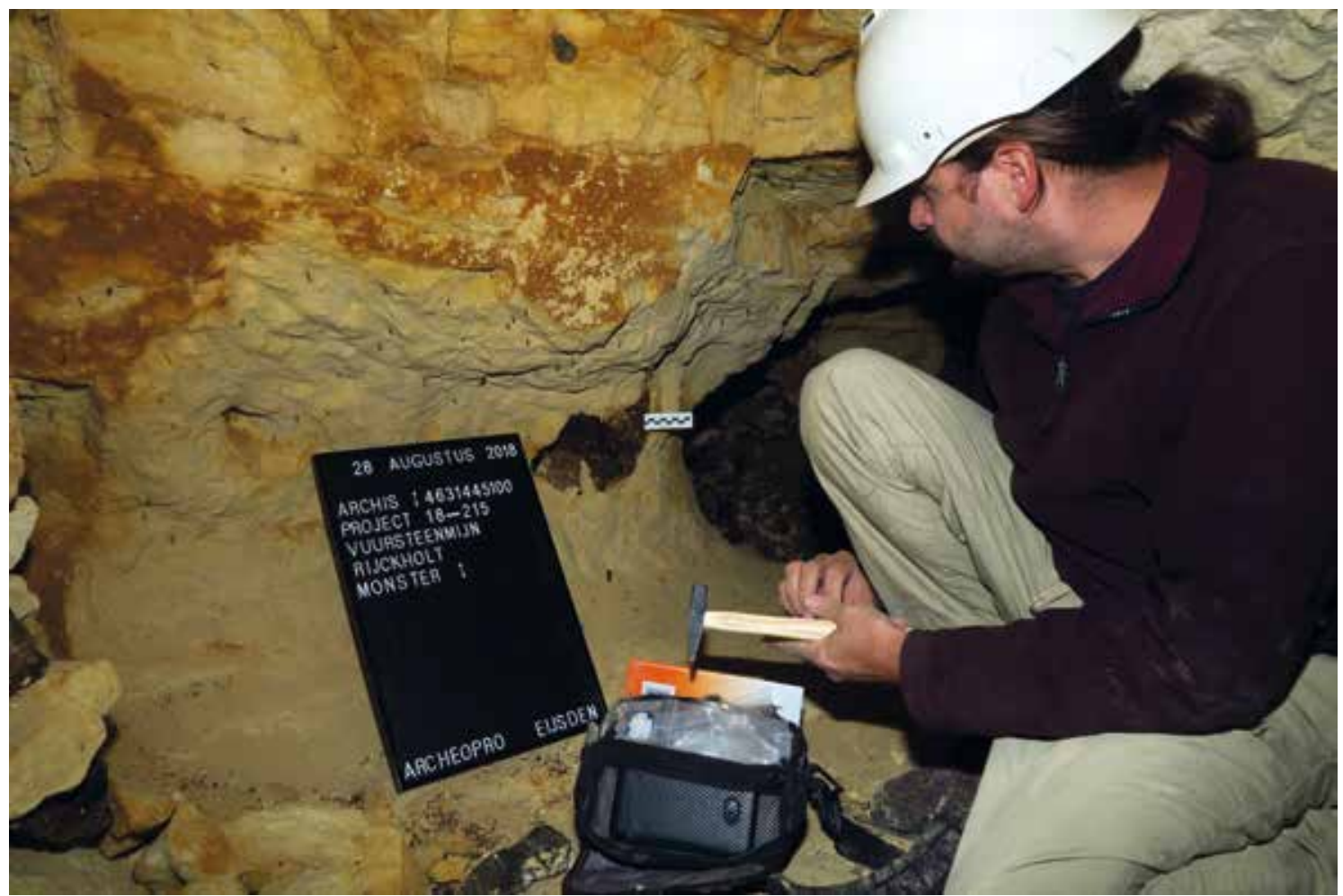

Fig. 71 Sampling the Rijckholt St. Geertruid flint mine, Netherlands (photo: G. Trnka)

focus on a chronological assessment of the quarries and attempt to trace the raw materials to lithic assemblages in Lower Austria, since there is currently no information concerning the extent of the use of Klippen Zone radiolarite. In the same context, a small test excavation was conducted in cooperation with the University of Vienna and the Stadtmuseum Wien from 29-31 May at the Gemeindeberg in Vienna (Ober-St.-Veit district). From here, (Late) Neolithic settlement traces have been known since the 1920s, with excavations initiated by Josef Fritz Kastner and later by Josef Bayer. The test excavation exposed a quarrying pit of as yet unknown depth, produced abundant quarrying and knapping debris (flakes, blades and cores) and evidence for fire setting as a mining technique. Five retrieved charcoal samples will allow for a dating of the site. These results raise the hope that radiolarite might have been mined at the Gemeindeberg in deep shafts similar to Vienna Mauer. Future research is planned to clarify this question.

The "Raw Material Project" is a long-standing research agenda with the aim of characterising the most important silicite raw materials throughout central Europe. One missing link in the geochemical database was the Rijckholt St. Geertruid flint mine in the Netherlands, which was especially important during the Michelsberg Culture (c. 4400-3500 BC). With special permission, Michael Brandl and Gerhard Trnka (University of Vienna) were able to sample the enigmatic flint layer No. 10, the goal of the prehistoric miners (Fig. 71), at the end of August. Geochemical analyses, which are planned for 2019, will enable us to create a "fingerprint" of this significant raw material and facilitate understanding of lithic resource networks in Late Neolithic central Europe.

During this year`s Svinjarička Cuka excavation campaign by the OREA Institute in southern Serbia, raw material analyses which were initiated in 2017 and have since been published (see Brandl, Hauzenberger 2018 in publication list) were continued in September 2018. In the course of geo-archaeological field surveys, eight distinct outcrops of chert were sampled for geochemistry. From each location 25 samples were collected to ensure statistically relevant results considering trace element distribution in specific outcrops. Additionally, the lithic archaeological material from Svinjarička Čuka was investigated, which comprises of chipped and ground stone tools. Chipped stone tools from the freshly exposed Neolithic contexts were also sampled for geochemistry. Preliminary microscopic on-site analyses revealed that the vast majority of all lithics from 
Cuka come from sources in the closer vicinity of the site. Thus, one goal of the future research is to establish a link between the results of the high resolution geo-archaeological sampling and the archaeological material to subsequently test raw material procurement strategies of the Neolithic farming communities in this micro-region. During this campaign, a future research cooperation with the Archaeological Museum of Macedonia in Skopje was established in order to compare Early Neolithic materials from a larger area.

In the course of the Platia Magoula Zarkou (Thessaly) publication project, archaeological material was provided by Catherine Perlès for geochemical analyses, which were performed in April. In order to obtain comparative geological samples, surveys were undertaken by Michael Brandl and Eva Alram-Stern around the city of Larissa in the central Thessalian basin in November. After consultation with Riccardo Caputo (University of Ferrara) and Georgios Toufexis (Ephorate of Antiquities of Larissa), the Pineios and Portaikos rivers, both bringing rock material from the Koziakas Mountains, as well as primary sources in the latter were examined. The field surveys revealed high quality radiolarite and chert in gravels of the Portaikos, and the same materials of lower quality in the Pineios. By contrast, our observations indicate a prevalence of rocks suitable for ground stone tool production in the Pineios. However, this observation needs further investigation. Additionally, primary sources of high quality radiolarite were detected in Mesozoic formations of the Koziakas Mountains. Both primary and secondary deposits carry material visually matching exactly the enigmatic "Pindos radiolarite" or "chocolate radiolarite", which makes us confident that the sources of this kind of material have been identified. Geochemical analyses will be undertaken for verification.

Two guest researchers from Turkey were hosted in the OREA Raw Material Lab between September and December, Yavuz and Buket Aydin from the University of Ankara. This collaborative effort focused on provenance studies of Lower Palaeolithic stone tools from Karain Cave, the most important Palaeolithic cave site in Turkey (See also the "Turkey Scientific Initiative"). For this purpose petrographic and geochemical analyses were performed on over 50 artefacts (Fig. 72) and a statistically relevant amount of geological comparison material from the vicinity of the site. Preliminary results are promising, and we are confident that we will be able to identify the sources used by Lower Palaeolithic people in the Karain Cave. The initial results were presented on December $4^{\text {th }}$ at the OREA Institute.

In November, Alba Masclans Latorre from the University of Barcelona conducted use wear analyses on ground stone tools from the early Neolithic burial site of Kleinhadersdorf in Lower Austria. First results indicate that the investigated stone axes were used for a wide array of tasks aside from woodworking.

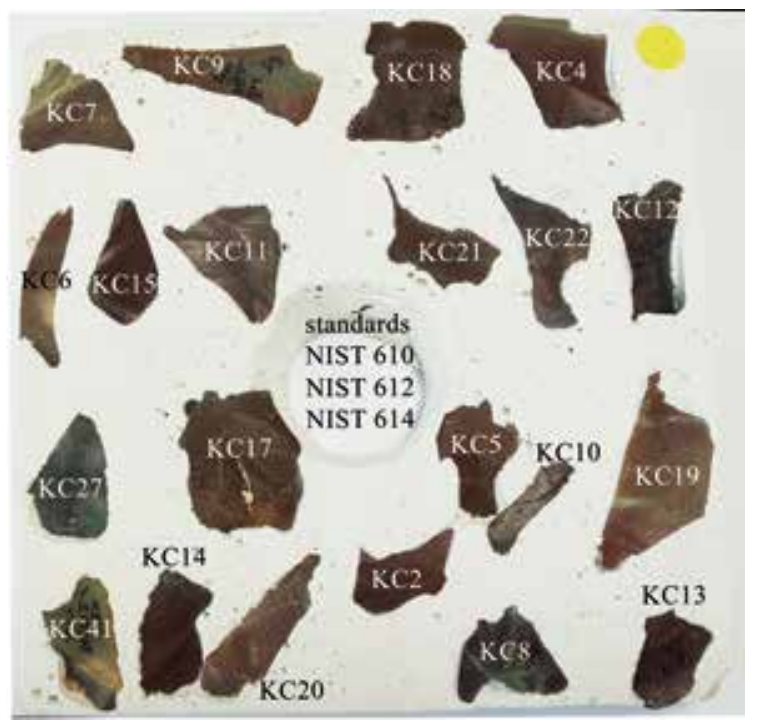

Fig. 72 Mount 1 for non-destructive geochemical analyses of stone tools from the Karain Cave (samples KC) (photo: M. Brandl, (C) OREA)
Lastly, three artefacts - a serpentinite axe head, a modern obsidian arrow head and a necklace with beads of as yet unidentified material - were brought in for an assessment by a rpivate collector. In the course of the assessments, the OREA Raw Material Lab Report Forms were implemented.

\section{Outreach activities}

- At the "BE OPEN - Science \& Society Festival" between the $8^{\text {th }}$ and $12^{\text {th }}$ September on the occasion of the $50^{\text {th }}$ anniversary of the FWF, the Raw Material Lab was represented with hands-on microscopic raw material analyses at the OREA Pavilion. 
- The exhibition "Messerscharf" (razor sharp) at the Universalmuseum Joanneum in Graz presented the results of 10 years of research at the Neolithic chert quarrying site of Rein in Styria. The exhibition opened on May $17^{\text {th }}$ and lasted until October $31^{\text {st }}$. Within the context of "Messerscharf", flint knapping was demonstrated during the "Long Night of Museums" on October $6^{\text {th }}$.

- In November, M. Brandl held a one-day workshop at the International Academy Traunkirchen together with Estella Weiss-Krejci. They provided detailed insight into applied archaeological and experimental techniques for interested pupils.

- An ERC Starting Grant with the title "ECOLITHICS - The emergence of 'modern' economic behaviour: lithic raw material economy in the Balkans as an indicator for Neolithisation" was submitted. In the context of this undertaking, collaborations with several research institutions throughout the Balkan region were established, including Albania, Macedonia, Serbia and Bulgaria. Additionally, a cooperation concerning the use of the Vienna Lithothec was achieved with the Institute of Prehistoric and Historical Archaeology (IUHA) of the University of Vienna.

- As in previous years, coursework on topics relating to raw material determination and lithic economy was provided at the IUHA. This included a course in the recording of Palaeolithic assemblages together with Thomas Einwögerer, and one lecture in the framework of the lecture series "scientific methods in archaeology".

- Finally, the results of geochemical analyses of erratic flint implements from Krems-Wachtberg were presented in June at the $18^{\text {th }}$ UISPP World Congress in Paris at the Session "Siliceous rocks: procurement and distribution systems" organised by the UISPP Commission on Flint Mining during Pre- and Protohistoric Times.

\section{Ceramic analyses \\ (Clare Burke)}

The Raw Material Lab has provided ceramic analysis as part of a number of new and ongoing projects, covering pottery from the Early Neolithic all the way through to the Late Bronze Age and geographical regions including Greece, Turkey and the Balkans.

Clare Burke has undertaken petrographic analysis of Early, Middle and Late Bronze Age ceramics from the site of Pheneos in Mainland Greece, funded by INSTAP, the preliminary results of which have been submitted for publication within a peer-reviewed conference volume.

The results of typological, macroscopic and petrographic analyses of Late Neolithic to Early Bronze Age ceramics from Midea have also been submitted for publication in collaboration with Eva Alram-Stern, and other project members, as part of a peer-reviewed volume from the international conference "The Wider Island of Pelops: a workshop on Prehistoric pottery in memory of Professor Christopher Mee", 18-19 September 2017.

In the summer Clare Burke travelled to examine Late Bronze Age ceramics from the Ada Tepe gold mine in Bulgaria together with Laura

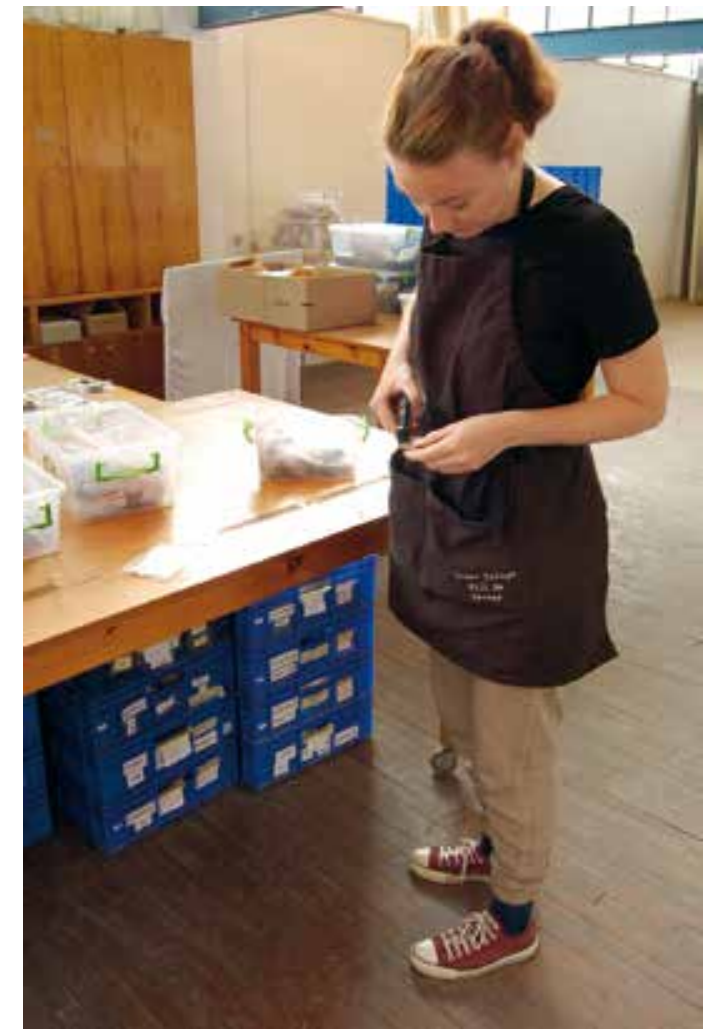

Fig. 73 Clare Burke sampling ceramics from Çukuriçi Höyük (photo: M. Röcklinger) 
Burkhart, who is studying the ceramics for her $\mathrm{PhD}$ thesis. Macroscopic details about the technology have been recorded and samples taken for more detailed analysis using thin section petrography. This collaborative project has subsequently been expanded to include examination of pottery from other parts of the mining complex, broadening OREA's cooperation with Bulgarian colleagues from the National Institute of Archaeology with Museum, Bulgarian Academy of Sciences.

As part of the Pusta Reka project team, Clare Burke travelled to Serbia to work with the pottery from the new excavations at Svinjarička $\check{C} u k a$ and to meet with colleagues at the archaeological museum in Skopje, Macedonia to begin a new collaboration examining the raw materials and technological development of Early Neolithic pottery.

She also travelled to Sweden to help develop a new collaborative project directed by Eva Alram-Stern that will examine Early, Middle and Late Bronze Age ceramics from the Asine collection, with an FWF application being submitted in 2019.

In Turkey she examined the Neolithic ceramics from Çukuriçi Höyük, looking at macroscopic evidence for their forming, finishing and firing technologies. A range of sherds were sampled for more detailed microscopic analysis in 2019 (Fig. 73).

Finally, Clare Burke is currently completing analysis of ceramic thin sections from Dolina in Croatia as part of the Burial project, the results of which will be published as part of the wider project.

\section{Leather and skin technology \\ (Gabriela Ruß-Popa)}

Within the framework of the Hertha Firnberg Programme funded by the FWF, Gabriela Ruß-Popa became part of the OREA Raw Material Lab team in October 2018. The title of her project is " $A$ diachronic study of animal resources: skin, leather and fur technologies based on selected find complexes from Central Europe and the Middle East" (FWF Project Number T-1025).

The project will last for three years and focuses on resource management strategies and technological aspects of the production and processing of animal skins, leather and fur. Two sites in Europe (Dürrnberg/Hallein in Austria and Glauberg in Germany) and one in the Near East (Chehrābād in Iran) where such materials have been preserved will be investigated. Methods include comparative, topological and material scientific analyses as well as experimental archaeology and the natural sciences. Investigating finds from such diverse cultural and chronological backgrounds will allow us to answer questions relating to economic archaeology and the history of culture and crafting on a broader scale.

\section{Events}

- 19.11.2018, Traunkirchen: "Messer, Mörser, Beil: Die Bedeutung von Steinrohstoffen im täglichen Leben prähistorischer Menschen" a one-day workshop at the International Academy Traunkirchen held by M. Brandl together with E. Weiss-Krejci. They provided detailed insight into applied archaeological and experimental techniques for interested pupils.

\section{Outreach activities}

- The publication of the article A multi-technique analytical approach to sourcing Scandinavian fint: Provenance of ballast flint from the shipwreck "Leirvigen 1", Norway in the journal PLOS ONE received broad attention from the press, and was covered by e.g. Science APA, Der Standard and Kurier.

- Michael Brandl together with curator Daniel Modl organized the Exhibition Messerscharf. 6000 Jahre Hornsteinbergbau in Rein bei Graz, 18.5.-31.10.2018. This exhibition presented the results of 10 years of research at the Neolithic chert quarrying site of Rein in Styria and was relized by the Archäologiemuseum Schloss Eggenberg part of the Universalmuseum 
Joanneum in cooperation with OREA and the Institute of Prehistoric and Historical Archaeology, University of Vienna, see also https://www.museum-joanneum.at/archaeologiemuseumschloss-eggenberg/ausstellungen/ausstellungen/events/event/6876/messerscharf.

- 8.-12.9.2018: "BE OPEN - Science \& Society Festival" between the $8^{\text {th }}$ and $12^{\text {th }}$ September on occasion of the $50^{\text {th }}$ anniversary of the FWF, the Raw Material Lab was represented with hands-on microscopic raw material analyses at the OREA Pavilion (see above pp. 18-21 for more details).

- 6.10.2018, Graz: During the "Lange Nacht der Museen" on October $6^{\text {th }}$ flintknapping was demonstrated to the public within the framework of "Messerscharf".

\section{Highlights 2018}

- An ERC Starting Grant with the title ECOLITHICS - The emergence of 'modern' economic behaviour: lithic raw material economy in the Balkans as indicator for Neolithisation was submitted by Michael Brandl. This project intends to investigate economic group behaviour based on lithic resource management strategies. This concept will be tested throughout the Balkan region, a key area for the understanding of the Neolithisation of Europe.

- The results of an extensive lithic provenance study with the title $A$ multi-technique analytical approach to sourcing Scandinavian flint: Provenance of ballast flint from the shipwreck "Leirvigen 1", Norway was published in the journal PLOS ONE. The outcomes demonstrate the potential of the Multi Layered Chert Sourcing Approach (MLA) using the example of Scandinavian Flint, an especially challenging undertaking, and can be regarded as a breakthrough in lithic provenance studies.

- A case study for sourcing lithic material from secondary deposits was successfully conducted with materials from the Leskovac basin in South Serbia. This area is rich in such secondary placer deposits of chert, jasper and chalcedony. The results were published in the Archaeologia Austriaca journal, https://austriaca.at/?arp=0x003a26c3.

- For the first time, it was possible to conduct provenance studies on Lower Palaeolithic stone tools from the world famous Karain Cave site near Antalya in Turkey. The importance of the site lies in its long-standing chronological sequence from the Lower Palaeolithic to the Holocene. The analyses were performed according to the MLA and revealed which of these sources were used by the Lower Palaeolithic inhabitants of the cave.

- It was also possible to sample the Rijckholt St. Geertruid flint mine in the Netherlands, as the first research team since the 1960s to do so. The incorporation of petrographic and geochemical data from this significant flint mine will achieve a finer resolution of raw material networks than previously possible, and be available for researchers in the form of an open access publication.

- One major success in geoarchaeological survey activities is the discovery of the sources of the enigmatic "Pindos radiolarie" in the framework of the Platia Magoula Zarkou publication project, a result which was greatly appreciated by local as well as international researchers working in Thessaly.

- The publication of a chapter by Clare Burke in OREA's Oriental and European Archaeology series volume "Pottery Technologies and Sociocultural Connections Between the Aegean and Anatolia During the $3^{\text {rd }}$ Millennium BC. Oriental and European Archaeology series". This chapter deals with Neolithic and Early Bronze Age ceramic production and distribution at Midea and Tiryns, two key centres for ceramic production in Greece.

Michael Brandl - Clare Burke - Gabriela Ruß-Popa 


\section{Digital Documentation LaB}

(Head: Mario Börner)

\section{Overall Objectives}

With the foundation of the DIGital Documentation Lab a central facility has been created, bringing the application of computer-assisted methods for capturing, processing and preparing research data in the diverse projects of the institute together. The Lab has been developed out of the former Digital Archaeology group and is now focusing on all the digital support archaeological research might need - professional excavation engineering and provision of all of computer-assisted methods for capturing, and the processing and preparation of research data.

The expertise of OREA's DIGital Documentation Lab are:

- GIS applications

- 3D modelling of archaeological finds and features at excavations

- digitizing, archiving and preparation for long-term preservation of analogue and digital research documentation

- integration and homogenisation of archaeological research data

- preparation for linking to e-research infrastructures

- data management

- ontologies

- research visualisation and dissemination to the public and researchers through digital resources

The DIGital Documentation Lab utilises state of the art technology (Fig. 74):

- Terrestrial 3D laser scanner Riegl VZ-400

- Multicopter DJI Inspire 1 Pro

- Breuckmann structured light 3D scanner

- Laser scanner Faro Edge $2.7 \mathrm{~m}$

- Totalstation Leica TS11 with GS12 GNSS Smart-Antenna

- Leica GS14 GNSS Smart-Rover

- Several high-performance desktop PCs and notebooks for photogrammetric applications

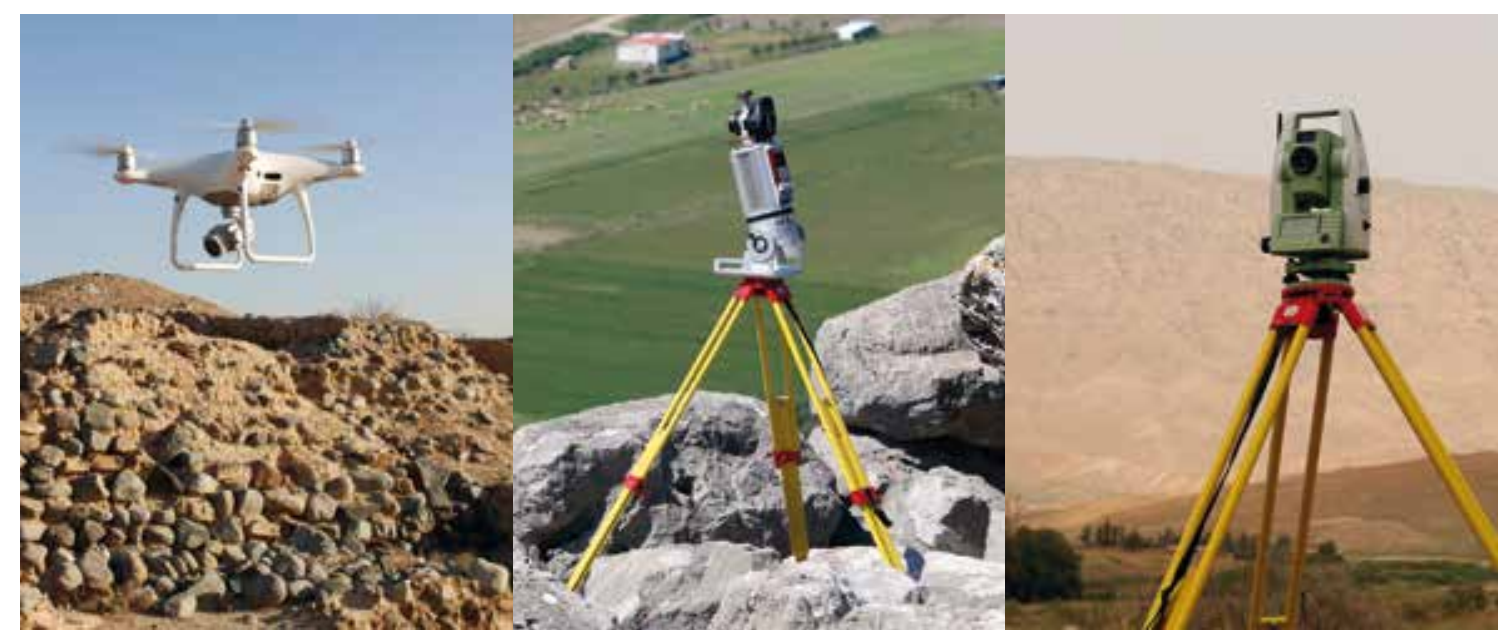

Fig. 74 High precision technical field equipment (photos: M. Börner, (C OREA) 
The DIGital Documentation Lab is responsible for the digital conservation and archiving of OREA research data and the transfer into long-term repositories in cooperation with the Austrian Centre for Digital Humanities - ACDH.

On the staff level, the team of seven people, under the direction of an academically trained excavation engineer, consists of archaeologists with relevant skills in informatics, graphics and visualization, merging archaeological and digital approaches to research.

The objectives of this facility are the development of workflows and best practice guides to create standards which meet the challenges of modern documentation and archiving, and to advance inter-institutional networking with national and international partners. Further, digital technological training of OREA researchers in the DIGital Documentation Lab will guarantee a large number of users of the state-of-the-art equipment and software, with training held on a regular basis and demand-oriented.

The completion of the transformation process into a technical service unit, supporting the OREA research projects is envisaged during 2019.

New in the portfolio of the DIGital Documentation Lab is not only the application of the latest software, but simultaneously the continuous and systematic development as well as refinement of specific software. Furthermore, the DIGital Documentation Lab assists at project proposal in an consultative role regarding the collection, processing and evaluation of primary data as well as the requirements to be fulfilled by the technical equipment concerned.

The expansion of the technical equipment for digital documentation and archiving in the field as well as in storage facilities is another major task - the realization is planned together with the Institute for the Study of Ancient Culture - IKAnt.

\section{Projects 2018}

In autumn 2018 two field campaigns in the Balkans were supported technically by the newly installed Lab. A 6 week field season in Svinjarička Čuka, Leskovac Basin, Serbia was carried out. The second was a 4 week campaign in Novo Selo, Bijeljina, Republic of Bosnia and Herzegovina, (Fig. 75).

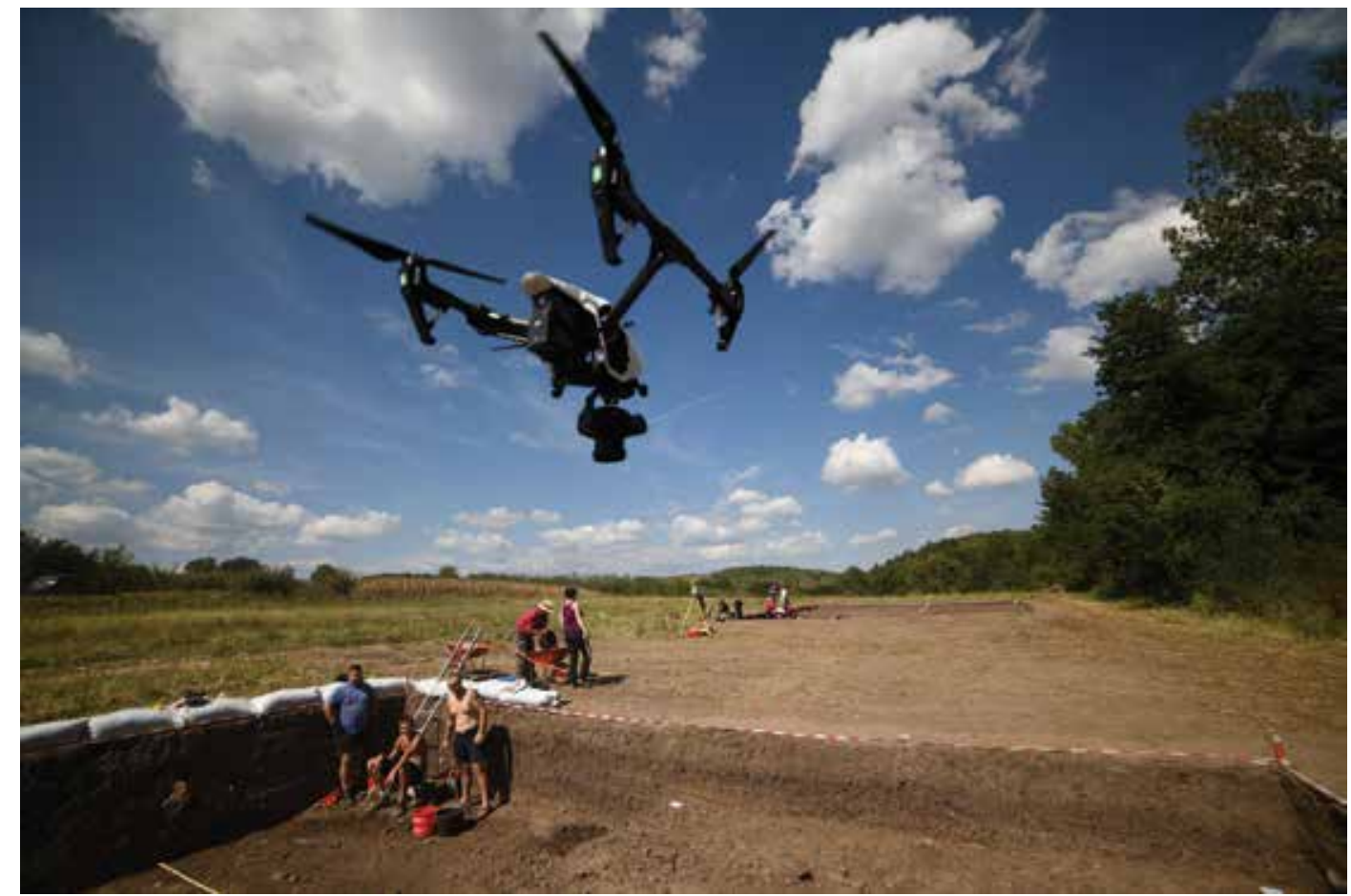

Fig. 75 Excavation autumn 2018 (photo: F. Ostmann, C OREA) 
In these campaigns, following the installation of a geographical measuring system via DGPSsystem and a topographical assessment, the geophysical data were used for the layout of the excavation areas and the survey trench systems.

The collection of all geospatial data, such as feature geometry and find distribution, was done exclusively digitally.

According to the particular requirements of each project, different combinations of tachymetric measuring systems and drone supported 3D photogrammetry were employed. The processing of the photogrammetric data was achieved by Agisoft Photoscan. The point clouds generated were then further processed into grid data sets as e.g. ortho photos and digital elevation models (DEMs). Together with the tachymetrically documented find distributions they served as basis for the GIS supported mapping, extended analyses and visualizations. These tasks represent the core competence of the DIGital Documentation Lab staff in terms of fieldwork and field documentation.

Several projects are tightly connected with the DIGital Documentation Lab, as their digital requirements are integrative components of the research methods and goals. These are:

- Digitizing Early Farming Cultures (https://www.orea.oeaw.ac.at/forschung/digital-documentation-lab/godigital-digitizing-early-farming-cultures/), managed by Edeltraud Aspöck

- Visualizing the unknown Balkans (https://www.orea.oeaw.ac.at/forschung/urnfield-culture-networks/visualizing-the-unknown-balkans/)

- Dokuplattform Thunau am Kamp (https://www.orea.oeaw.ac.at/forschung/urnfield-culture-networks/thunau-am-kamp-eine-befestigte-hoehensiedlung-der-urnenfelderkultur/dokuplattform-thunau-am-kamp/)

- ARIADNE (https://www.orea.oeaw.ac.at/forschung/digital-documentation-lab/ariadne/), managed by Edeltraud Aspöck

- Zentrum oder Peripherie? (https://www.orea.oeaw.ac.at/forschung/material-culture-inegypt-nubia/zentrum-oder-peripherie/)

- A Puzzle in 4D (https://www.orea.oeaw.ac.at/forschung/digital-documentation-lab/a-puzzlein-4d/), scientific coordination by Edeltraud Aspöck

\section{A Puzzle in 4D: digital preservation and reconstruction of an Egyptian palace}

PI: Barbara Horejs, project staff: Edeltraud Aspöck (scientific coordinator), Angela Schwab (project management), Karin Kopetzky (archiving), Martina Simon (project assistant), Karl Burkhart, Stefanie Fragner, Irene Petschko, Julian Posch (digitization, metadata entries)

In 2018 a large volume of analogue documentation resources from the excavations at Tell el-Daba in Egypt was digitized. With the arrival of the new Noritsu HS-1800 film scanner at the ÖAW $\mathrm{ACDH}$, it was possible to digitise a large part of the Tell el-Daba photographic resources, scanning 47,000 photos and providing around 18,000 metadata entries for long-term archiving and openaccess online publication. Unfortunately, the previous storage conditions of the black and white negatives resulted in damage so an additional part of the work after their digitisation was to store the analogue resources in new folders with acid-free covers to ensure long-time preservation. The digitisation of the large and fragile plans (ink on transparent paper) was achieved with the new camera scan system Phase One at the ÖAW ACDH, which allows high resolution non-destructive recording. Numerous analogue resources are stored in the archive of the ÖAI at Cairo and one of our team members spent 2 weeks there to scan protocols and field drawings which are missing in the OREA archives. Furthermore, we were able to finish the digitization and the enrichment with metadata of the inventory books and are going to finish the metadata of each inventory entry of the finds in spring 2019 thus bringing these resources together (Fig. 76).

Funding: Österreichische Nationalstiftung für Forschung, Technologie \& Entwicklung (DH 2014/12)

Project partners: Tell el-Daba Publications, AAS ACDH, Austrian Archaeological Institute (ÖAI), Ludwig Boltzmann Institute Archaeological Prospection and Virtual Archaeology (LBI ArchPro), PIN, ADS, University of Chicago, Universität Bochum 


\section{Presentations 2018}

- Gerald Hiebel (29.5.2018), “A Puzzle in 4D” At: ÖAW ACDH Tool Gallery 4.1, 29 May 2018 - Workshop on ontology engineering with a special focus on CIDOC CRM https://www.oeaw. ac.at/acdh/events/event-series/event-detail/article/acdh-tool-gallery-41/

- Irene Petschko - Edeltraud Aspöck (19.3.2018), "From analogue field documents to digital objects - A Puzzle in 4D.” At: CAA Twitter Conference, 19.3.2018 (Tübingen/Germany, March 2018). https://twitter.com/OREA_digArch/status/976007601455443968

\section{Highlights 2018}

- Lange Nacht der Forschung, 13 April 2018 - Presentation of our 3D models and the walkthrough (https://4dpuzzle.orea.oeaw.ac.at/reconstruct/)

- ÖAW ACDH Tool Gallery 4.1, 29 May 2018 - Workshop on ontology engineering with a special focus on CIDOC CRM.

- New camera scan system Phase One at the ÖAW ACDH - for scanning large and fragile documents

Mario Börner - Edeltraud Aspöck - Martina Simon
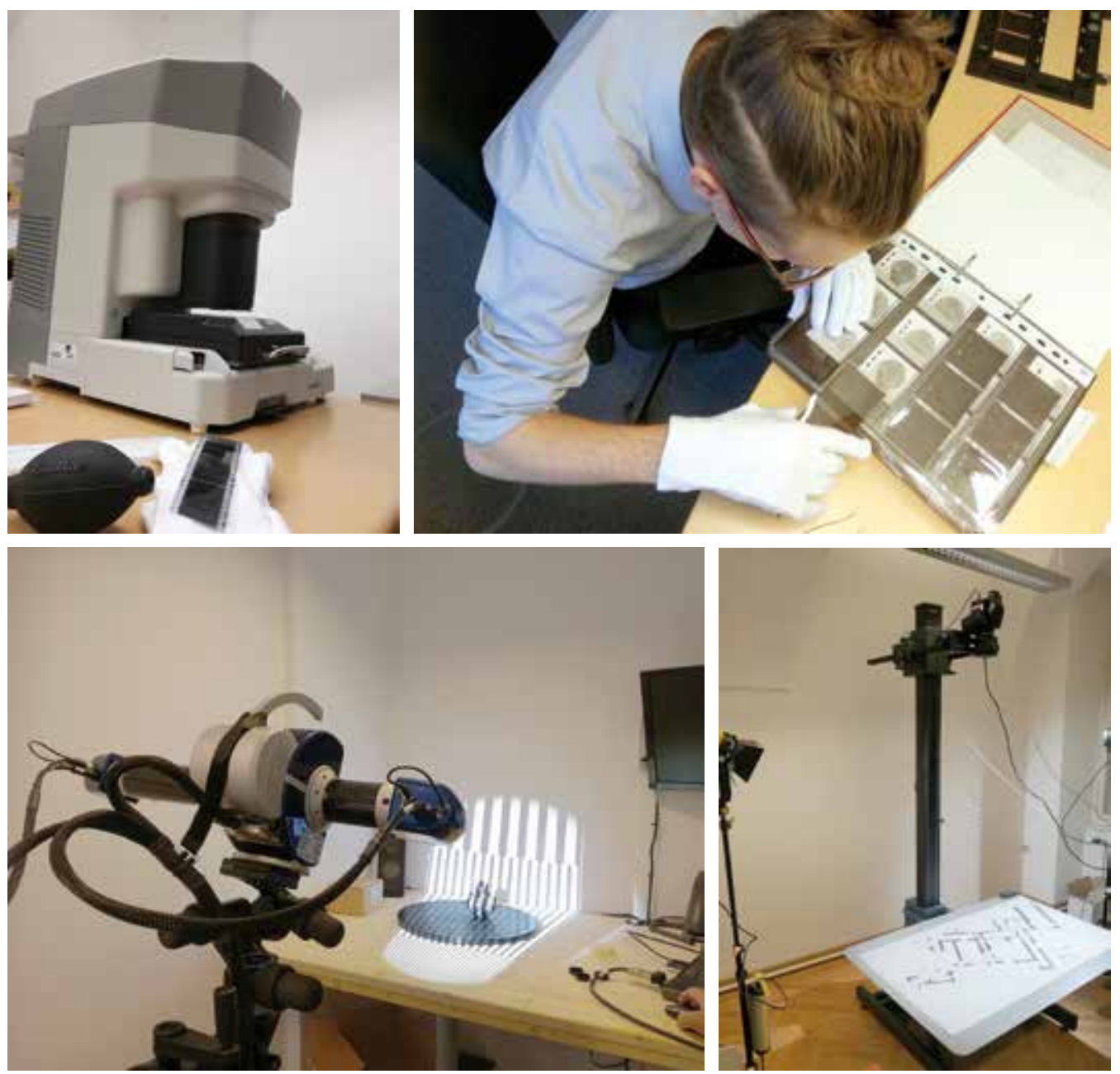

Fig. 76 Digitizing the Tell el-Daba archives (photos: M. Simon, (C) OREA) 


\section{ACross AnCient Borders and Cultures}

(Principal Investigator: Julia Budka)

\section{Objectives and results}

The research project Across Ancient Borders and Cultures (START project J. Budka, 20122017) focused on settlement patterns in Northeast Africa of the 2nd millennium BC based on the detailed analysis of material remains. It has achieved an important advancement in the field of settlement archaeology in Northeast Africa with new excavations at two significant sites of the Egyptian New Kingdom - Sai in modern Sudan and Elephantine in Egypt - which yielded large amounts of new material and new data sets, based on modern techniques of analysis and recording in the field.

On Sai Island, the focus was on the virtual reconstruction of the town area, the assessment of certain groups of objects, and the study of human remains from a newly discovered tomb. The size, layout and evolution of the Egyptian town of Sai can now be safely recreated, including a $3 \mathrm{D}$ reconstruction of the settlement based on a 3D laser scanning campaign. Considerable differences between urban sectors were noted, suggesting some impact of individuals and spontaneous dynamics of the settlement, despite of general state planning.

On Elephantine Island, the work focused on the study of the ceramics from $18^{\text {th }}$ Dynasty levels of a structure labelled House 55, which was completely excavated within the framework of the project. House 55's excellent state of preservation and the large amount and quality of pottery and other finds exceeded all expectations. In addition to the important general comparison between the two ceramic corpora from Sai and Elephantine, the new stratigraphic sequence from Elephantine has resulted in new ceramic studies of the New Kingdom that include the important preceding phase, the late Second Intermediate Period.

As result of the comparative approach of the project, the original hypothesis of Sai Island as an Egyptian microcosm could be confirmed. Further, the old theory of strict boundaries between Nubians and Egyptians, and social stratification based on origin, could be disproved, as such the older theories can now be replaced by the metaphor of cultural entanglement in a complex two-way mixture of lifestyles. This project illustrates Sai as very significant for understanding the most important aspects of New Kingdom colonial strategy in Nubia: Sai became home not only for Egyptians, but also for Nubians who intermingled with the "colonialists". As a whole, the project demonstrates the coexistence of Egyptians and Nubians as a case study that highlights dynamic aspects of, and individual options within, acculturation processes. This ancient example of complex intermingling of cultures might also be instructive for modern studies of multi-ethnic communities in urban spaces.

\section{Current research}

The project was successfully completed by October 2017 and work is now focused on the preparation of final publications, in particular on the results of the strontium isotope analyses and a monograph dedicated to Tomb 26 on Sai Island. 


\section{Ankh-Hor Project \\ (Principal Investigator: Julia Budka)}

\section{Objectives}

The new Ankh-Hor Project, hosted at the LMU Munich and conducted in cooperation with OREA and ÖAI, was launched in 2018. Its principal aim is a complete study and analysis of finds excavated under the directorship of Manfred Bietak in the years 1969 to 1979 in the Asasif, Egypt, first of all from TT 414. TT 414 is the monumental tomb of Ankh-Hor, High Steward of the Divine Adoratrice Nitocris (26 ${ }^{\text {th }}$ Dynasty). Although TT 414 was published soon after excavation as a two volume monograph by Manfred Bietak and Elfriede Reiser-Haslauer, large amounts of finds from the Austrian excavations are as yet unpublished and were left on site in the mission's storeroom. This material holds rich potential for understanding the funerary customs in the Late Period, the Ptolemaic and Roman era and has not yet been published.

The exhaustive documentation of the objects brought to light by the Austrian mission during the 1970s and now conducted by the new Ankh-Hor Project offers a unique opportunity to both study and preserve a large corpus of material coming from scientifically up-to-date excavations and covering a timespan from the $26^{\text {th }}$ Dynasty up to Roman, and even Coptic times. Due to their unusually secure context, the objects from TT 414 may serve as important terms of reference in order to analyse many objects without provenance in museum collections throughout the world. This will enable us to gain further insights to the specific usages and functions of monumental tombs in the Asasif in general, and to increase the understanding of the connections, interrelationships and developments between the $26^{\text {th }}$ and $30^{\text {th }}$ Dynasties and Ptolemaic and Roman times.

\section{Current research}

The first season was successfully conducted from March 10 to March 292018 in the mission's storeroom, that is, Tomb 1 of the former Austrian concession, a Middle Kingdom saff-tomb

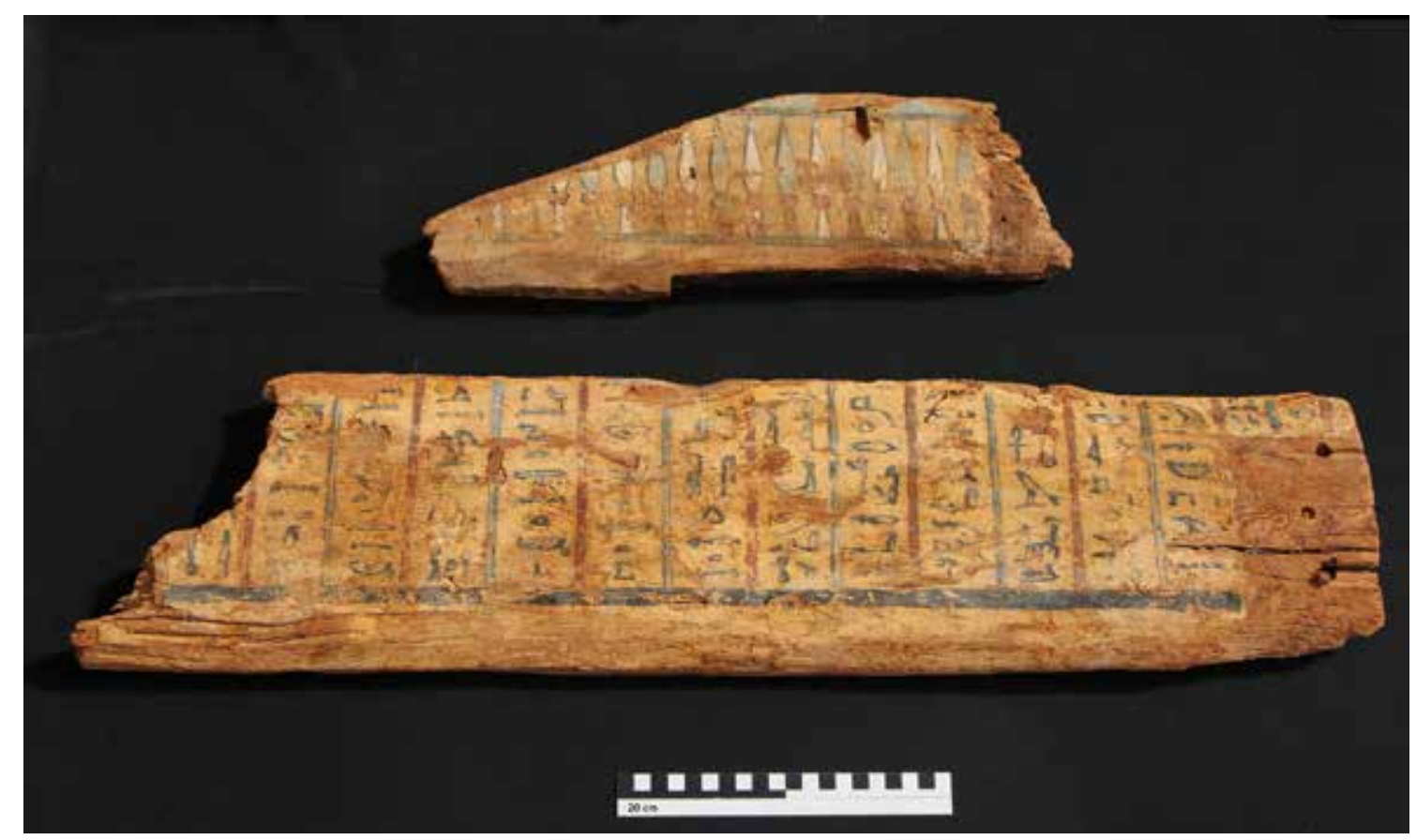

Fig. 77 Fitting parts of the qrsw coffin of the daughter of Ankh-Hor (photo: C. Geiger, (C) Julia Budka) 
(MM 737 of Winlock's cemetery 700) located opposite TT 27, the tomb of Sheshonk of the $26^{\text {th }}$ Dynasty.

During the study season in 2018 the documentation of the finds continued, with a focus on the coffins from the tomb of Ankh-Hor. These coffins belong both to primary burials of the family of Ankh-Hor and to secondary burials of Amun priests, mostly dating to the $4^{\text {th }}$ and $3^{\text {rd }}$ centuries BC. Some pieces were identified for the first time and correlated with the documentation from the 1970s, alongside othermaterialrecorded for the first time. All finds were digitally photographed and entered in a database, created in File Maker Pro. A total of more than 80 drawings were produced in 2018, comprising small finds (24 drawings, mostly Ptolemaic faience shabtis with texts bearing the names of their owners), wooden objects including a PtahSokar-Osiris statue ( 5 drawings in total) and pottery ( 55 pottery vessels and fragments, mostly Ptolemaic from the re-use of TT414, but also Saite vessels).

In addition to these drawing, 360 objects were photographed with a full-frame camera with very high resolution. These objects were primarily coffin fragments, fragments of wooden shrines and boxes and shabtis. The new photos from the 2018 season are suitable for publication and allow a detailed study of the inscriptions of a large number of objects, primarily coffins.

Conservation work, conducted by Daniel Oberndorfer (ÖAI) focused in the 2018 season on wooden objects, especially on coffins and fragments of shrines and wooden statuettes (PtahSokar-Osiris figures).

One main aim of the season was joining fragmented pieces of coffins together. The success of this task can be illustrated by one example (Fig. 77) - the side board of the qrsw coffin of the daughter of Ankh-Hor was already published in 1982 and cleaned in 2009. This season, we managed to locate a small fragment in one of the boxes which must come from the same coffin. It is a small fragment from the vaulted lid of a qrsw coffin showing an ordinary kheker-frieze. The style of painting and the colours, as well as the quality of the wood and the thickness of the board, correspond to Reg. No. 377b, the fragment bearing the name of Merit-Neith. Interestingly, the find position for this new piece is documented: it was found together with other fragments of $26^{\text {th }}$ Dynasty qrsw coffins in the shaft filling from room 8 in TT 414 . Until this season, we had no clue where Merit-Neith was buried within TT 414. Now, it is likely the chamber at the base of the shaft from room 8 was her original burial place. Small matches like this example illustrate how much potential there is in the new detailed analysis of all finds from TT 414 which is currently being undertaken.

Julia Budka 


\section{The EnigMa of THE HyKsos}

(ERC Advanced Grant Project; Principal investigator: Manfred Bietak)

\section{Objectives}

In total, the Hyksos Enigma project runs for five years and explores the origin, the ethnicity and the influence of the 'rulers of the foreign countries' - the Hyksos, ruling the North of Egypt in the Second Intermediate Period. Therefore, archaeological findings from several missions working in the Eastern Delta of Egypt, have to be compared to structures and objects known from the Levant and surrounding regions.

\section{Current Research}

Preliminary possible outcomes become more apparent and all research tracks are so far within their foreseen time schedules. The project team is now complete and project related tasks are implemented and progressing steadily. Above all the Bournemouth University has granted one additional member of staff, Arwa Kharobi, to join the bio-archaeological team and to support efforts within Research Track 8 (7). Her broad experience, especially of sites in the Near East, will surely contribute to the compilation of complementing information to this interdisciplinary project.

In order to achieve all deliverables set by the project, slight adaptions were necessary, as i.e. site visits on location in Egypt are not possible, due to various reasons, one of which is that so far the Academy has not succeeded gaining a granted security. Which means a visit to the material at Tell el-Dacba was until now not possible and therefore resources of some team members had to be used to find relevant material elsewhere, outside of Egypt. Somehow, this option was accounted for from the outset; nevertheless, it is time consuming and these efforts could be used otherwise. Thankfully, there are research institutions who want to help out and cooperate with the project team to alleviate the associated problems.

It is testimony to the good work of the project team that alternative routes have been considered, but there is of course still hope that the vital material placed at Tell el-Dacba can be viewed before the project ends and enough time remains to sufficiently analyse and scrutinise this material. Hence a variety of samples from Vienna, Canada, Lebanon and Australia have been transferred to some laboratories for further investigations, for which results are awaited in the following year.

Liaising with other research organisations, universities and researchers is an ongoing process as besides sourcing much needed material also complementing research and the opinions of other researchers seem important to the progression of interdisciplinary projects. Therefore, conferences and workshops have been visited, seminars (internal as well as external) have been attended and invitations to present have been accepted.

The third year of the project has started with avid preparations for a Hyksos Workshop at the $11^{\text {th }}$ ICAANE, which took place from the $3^{\text {rd }}$ until the $7^{\text {th }}$ April 2018 in Munich. Most team members gave presentations and within this project workshop, invited researchers used the topical platform to present related topics and work (Fig. 78).

Besides this, the team in Vienna concentrated efforts on a poster presentation at the 'Lange Nacht der Forschung' (13.4.2018 on various locations throughout Austria attracting a large audience of over 200,000 visitors), where the Austrian Academy provided Orea a display area to introduce ongoing research work and projects to the broader public. The poster included a brief description of the Hyksos Enigma Research Tracks, and project members were on site to answer any questions the visitors had. This was a different possibility for outreach and similar events would be welcome to highlight the ongoing work of the team.

Elisa Priglinger (RT 2) attended also the AMPAH in London (17.3.2018) and the 50. SÄK in Münster (13.7.2018), where she presented her work, whilst the PI, Prof. Bietak gave keynote lectures at the 64. RAI Assyrology in Innsbruck (16.-20.7.2018) and the $8^{\text {th }}$ Maimonides Lectures in Krems (28.11.2018). He was also invited to the $7^{\text {th }}$ Melammu Workshop in Padua (5.-7.11.2018), all of which lent possibilities to report on the ERC project. Together with Sarah Vilain he also at- 


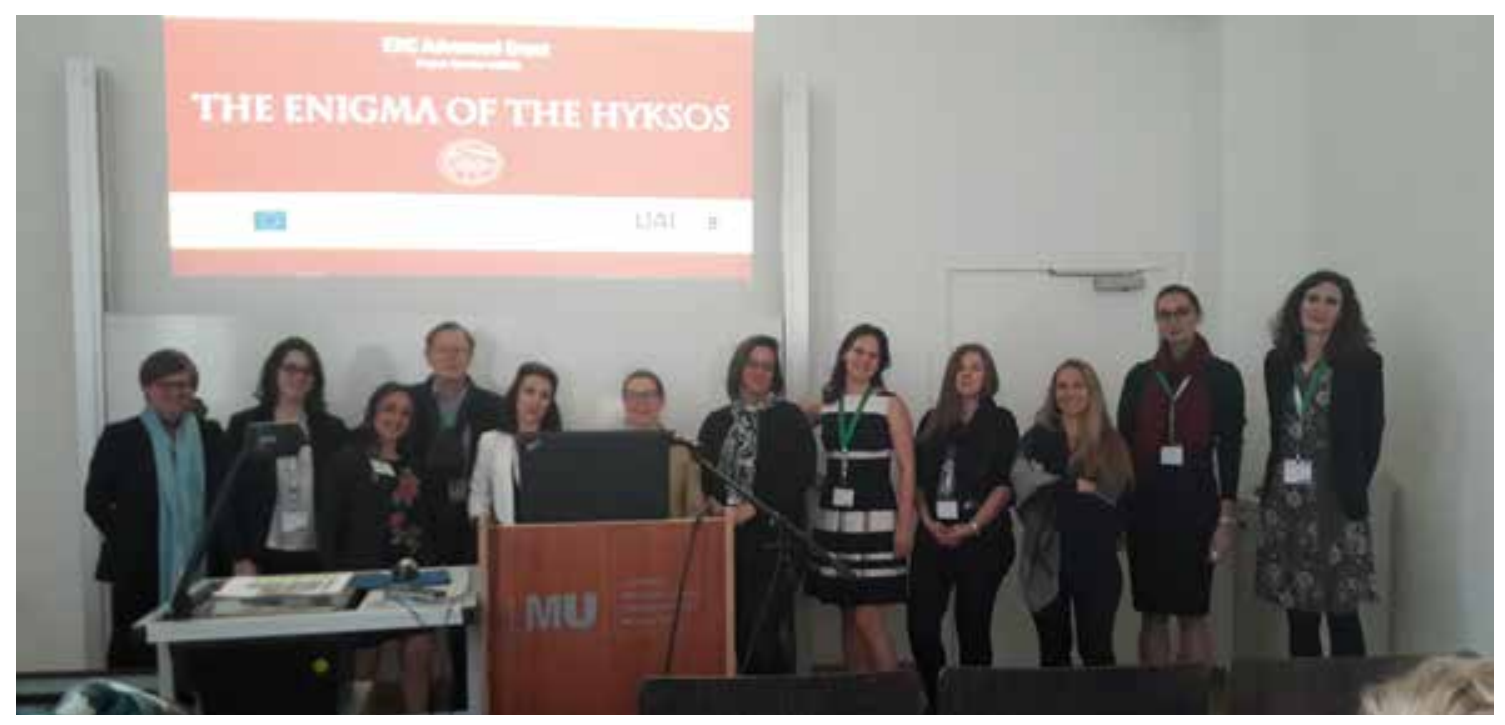

Fig. 78 Hyksos Enigma Workshop at the $11^{\text {th }}$ ICAANE in Munich (C The Enigma of the Hyksos)

tended the Crossroads III, in Prague (10.-13.9.2018). Anna-Latifa Mourad received an invitation to present at the ASOR 2018 in Boston (12.-17.11.2018). A great opportunity for the PhD student Silvia Gómez-Senovilla presented itself in form of a lecture as well as a poster presentation at the VI Congreso Iberoamericano de Egiptologico in Madrid (3.-5.12.2018).

The researchers from the BU, Nina Maaranen and Christina Stantis organised one trip to Australia at the beginning of the year (Fig. 79), spent time over the summer at excavation sites in the Lebanon and viewed sample material at the Forensic Institute and the Naturhistorische Museum in Vienna, during May and November 2018. They also attended numerous workshops, training courses and seminars, crucial for the project advancement.

Furthermore, the foreseen publications are being discussed in more detail and plans about the time schedule for the remaining two years become more concrete. It is envisaged for each research track to provide textual material, which can be seen as a collection at the end. The individual progress can be summarised

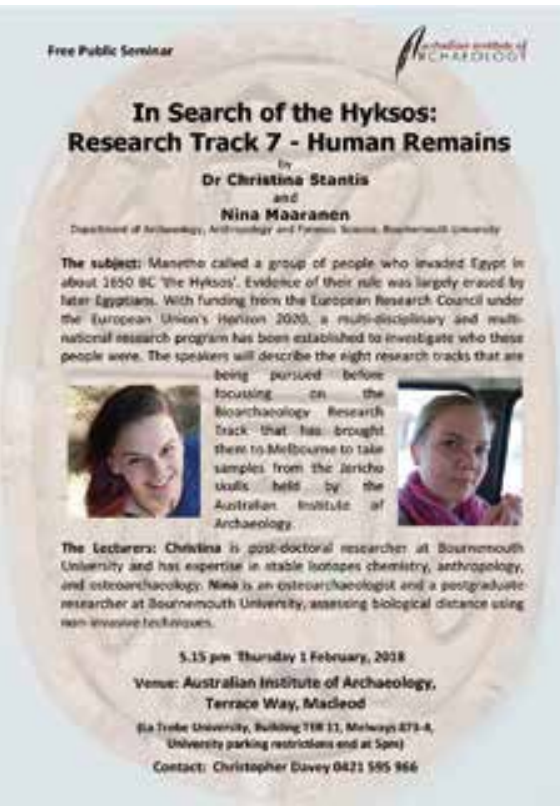

Fig. 79 BU Poster about lecture Nina Maaranen and Christina Stantis at the Australian Institute (C) The Enigma of the Hyksos) as follows: Elisa Priglinger (RT 2) finished an article called 'The Role of Migration Theory in Egyptology'; Silvia Prell (RT 3) advances her work on 'The Burial Customs in the Ancient Near East in Diachronic Perspective: From the Early to the Late Bronze Age'; Silvia Gómez-Senovilla (RT 4) is proceeding with her thesis 'Settlement pattern and Settlement Morphology at Tell el-Dabca and the Ancient Near East' and meeting additional milestones within her doctoral studies; Anna-Latifa Mourad (RT 5) edited a manuscript by E. Bumann 'The Hyksos and Acculturation' and continues work on her monograph 'Cultural Interference of the Hyksos and their aftermath'; Sarah Vilain (RT 6) submitted an article in Egypt and Levant 28. Along his various commitments the PI is preparing a book on 'The spiritual Homeland of the Hyksos: A Comparative Architectural Study on Temples in the Ancient Near East.' As part of the FWF Project Palaces in Egypt, the follow up volume of 'Ancient Egyptian and Ancient 
Near Eastern Palaces Vol. I' was edited and put to press. Proceedings of project workshops at the ASOR 2017 and $11^{\text {th }}$ ICAANE 2018 will be published in the near future.

Towards the end of the year, the project underwent an audit organised by the Academy and another one put forward by the EU (11/2018). Both audits went well, only minor issues were highlighted and the positive reports are expected in the New Year.

The results of the ERC Advanced Grant are exciting. An architectural comparative analysis of temples in the Near East revealed that the decision makers in Avaris had their spiritual roots in northernmost Syria and in northern Mesopotamia. It became now the question again, if Hurrians, who lived in this region were a part of the Hyksos elite. Another study, the comparative analysis of burial customs produced similar results. Attendant burials as found in Phase F in Tell el-Daba (c. 1700 BC) have thus far only parallels at Tell Arbid in the Khabur region in northernmost Syria. The distribution of intramural burials and the of graves with weapons as offerings spread from Anatolia to northern Syria and Mesopotamia in order to disappear afterwards in northern Syria in favour of a southward distribution in the Middle Bronze Age. It looks like a southward movement of population.

The study of the impact of the Hyksos on the Egyptian culture of the New Kingdom showed that a fair amount of the Asiatic population stayed in Egypt after their defeat. Their technological skills were used especially in the Egyptian military production, in glyptic art.Also the religion and spiritual world of the Near Easterners entered Egyptian cult and literature. The cultural interference during the Second Intermediate Period was subject of a manuscript of Ernest Bumann which was completely edited by Anna Latifa Mourad. It analyses the complicated acculturation process of the Asiatic population in the Eastern Delta with the Egyptian population and even shows an arrest in this process and a retreat to Near Eastern traditions. Gas-chromatographic investigations identified aromatic essences in different kinds of wares, especially Tell el-Yahudiya Ware. The Bournemouth team had access to osteological material from the Lebanon, Syria, Jordan and Egypt from different excavations and museums. Results can be expected this year. External colleagues work on onomastic studies in order to assess if besides Western-Semitic also names with different roots are present in the collection.

For more detailed information on the project: http://thehyksosenigma.oeaw.ac.at/

Manfred Bietak 


\title{
Longterm Research
}

\author{
F.E.R.C.AN. \\ Fontes Epigraphici Religionum Celticarum Antiquarum \\ (Principal Investigators: Gerhard Dobesch and Herwig Friesinger, \\ coordination: Manfred Hainzmann)
}

Ancient inscriptions containing names of gods and religious terms on monuments and small finds are of outstanding importance for knowledge of Celtic religion in its various forms. Equally revealing are the evidence of votive offerings, the groups of dedicators and their motives. So far, these sources have never been systematically documented and analysed; a research gap shall be closed through the F.E.R.C.AN. Project of the Austrian Academy of Sciences launched in 1998.

The aim of this major international project is the complete documentation, new edition and analysis of Greek, Latin and Celtic written records of religious content. As part of the edition, archaeological and historical findings, as well as linguistic-philological and religious studies, will be taken into account. For this reason, an interdisciplinary research advisory committee was established to support the epigraphic research.

The first volume of the series Corpus - F.E.R.C.AN. (Fontes epigraphici religionum Celticarum antiquarum), re-edits religious inscriptions from the provinces of the Roman world with a probably Celtic-speaking background. The F.E.R.C.AN. editions are meant to offer not only a thorough philological commentary on and a translation of the documents collected, but also an in-depth interdisciplinary analysis and classification of the invocations and the divine names contained in them, from a linguistic, an epigraphic-historical, and also an iconographical perspective.

It collects the Norican evidence and consists of two fascicles. In the first one, a methodological section ("From divine names to deities? On the analysis of the divine names") is followed by a section discussing the numina in alphabetical order and comprising the individual linguistic and historical commentaries on the invocations attested, together with several tables illustrating the diffusion of the single Norican cults, their mutual relationship, and the social provenance of their dedicants. An iconographical analysis of the few extant representations of 'Norican' numina constitutes the third main section of Fasciculus 1. An extensive and well-illustrated inscription catalogue represents the core of Fasciculus 2, with 145 tituli scalpti and 13 instrumenta inscripta, while an appendix with concordances of the votive strings and the personal names contained in the documents is distributed, together with further information, over both fascicles. The mvolume has been accepted by the publication committee of the AAS and is currently in preparation for publication.

\section{Scientific Board:}

Helmut Birkhan (Vienna, Department of German Studies)

Patricia de Bernardo Stempel (UPV/EHU, Linguistica and Celtic Studies)

Gerhard Dobesch (Vienna, Department of Ancient History, Papyrology and Epigraphy)

Ute Klatt (Mainz, Department of Ancient History and Classical Archaeology)

Nicolas Mathieu (Grenoble, Department of Ancient History)

Francisco Marco Simón (Saragossa, Deparment of Religious Studies)

Otto H. Urban (Vienna, Department of Prehistoric and Historical Archaeology)

Rainer Wiegels (Osnabrück, Department of Ancient History and Epigraphy)

Funding: FWF P 14306

Manfred Hainzmann 


\section{The Temple Inscriptions from Philae}

(Principal Investigator: Holger Kockelmann, senior research associate: Erich Winter)

\section{Overall Objectives}

The temples of Philae, now located on Agilkia island some $5 \mathrm{~km}$ south of Aswan, form a conglomerate of sanctuaries, colonnades, kiosks and gates. The long-term objective of the Philae Temple Text Project (Projekt Edition der Tempelinschriften von Philae) is to publish the hieroglyphic reliefs of all these buildings. The latest monograph of the Philae Temple Text series, which has appeared in 2016, is devoted to the Second East Colonnade of the great Temple of Isis. The next volume will contain a complete edition of the scenes and inscriptions of the Temple of Hathor, which are partly unique and many of which represent key sources for the study of Egyptian religion. Apart from text editions, the project publishes studies on the cults, theology and history of Philae.

\section{Research 2018}

The Philae Temple Text Project continued to study the hieroglyphic Philae reliefs and conducted two field work campaigns in April/May and October/November. Members of the 2018 mission were Holger Kockelmann (Director/ Field Director), epigraphist Silke Caßor-Pfeiffer, Juliette Fayein (restorer). Representatives of the Ministry of Antiquities were inspectors Mikel Kamal Nader, Alyaa Abdelmonsef Hassan Ali, Ranya Tageldeen Barsi, and Mohamed Abderraziq, joined by restorers Mohamed Abdeldayem and Ahmed Tawfik.

The team continued the epigraphic survey of the decoration of the Philae Temple of Hathor (Fig. 80). Thanks to the financial support by the "Holzhausen Legat", around 50\% of the Hathor Temple reliefs were copied in high quality facsimile since 2016 . Another $25 \%$ could be drawn in facsimile in 2018 with funding kindly provided by the Michela Schiff Giorgini Foundation (Geneva); all facsimiles were done by our epigraphic draughtswoman Pauline Calassou. During the field campaigns, the team collated a part of the aforementioned facsimiles with the original reliefs and priority was given to the scenes and inscriptions of the columns of the entrance

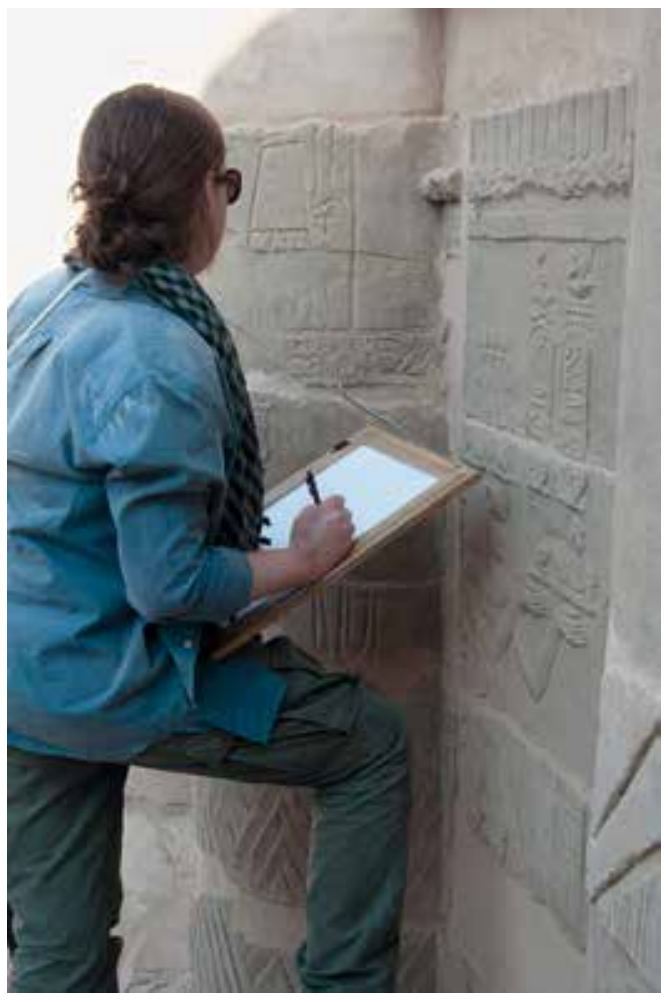

Fig. 80 Project member Silke Caßor-Pfeiffer checking facsimiles in the Temple of Hathor (photo/C) H. Kockelmann) kiosk. Additionally, the photographic documentation of the Temple of Hathor was supplemented. All inspectors of the Ministry of Antiquities taking part in the mission received an introduction into the history, theology and temple decoration of Philae by the mission members and were trained in reading and copying hieroglyphic inscriptions.

The Philae Temple Text Project has not only been active in epigraphic research, but has also engaged itself intensely in site management. The new project The Second Salvage of the Temples of Philae, which is funded by the Gerda Henkel Foundation (Düsseldorf) and devoted to the long-term preservation and documentation of the decorated temple spolia found during the UNESCO translocation of the temples in the 1970s, has almost been completed. More than 270 temple blocks and block fragments were transferred from a storage depot to Agilkia island, where they are now stored under ideal conditions next to the temples of Philae. Thanks to the work accomplished by the mission, this 
unique epigraphic material has become accessible to scholars and the public for the first time. It comprises spolia from the Ramesside Period (c. 1279-1070 BC), the reign of the Kushite king Taharqa (690-664 BC), the earliest temple of Isis on Philae (pharaohs Psametik II, Amasis, and Nectanebo I, $6^{\text {th }}-4^{\text {th }}$ centuries $\mathrm{BC}$ ) and from the Graeco-Roman period ( $3^{\text {rd }}$ century BC to $1^{\text {st }}$ century $\mathrm{AD}$ ). In total, three new storage areas were created, with single blocks and reconstructed relief walls placed on supports. Spolia which needed cleaning and consolidation, were treated by restorers Juliette Fayein, Mohamed Abdeldayem, and Ahmed Tawfik. A selection of the historically most important blocks and scenes can be seen by visitors of the temples at the Temple of Hathor and in Agilkia north-east. Visitor signs, which provide essential background data on the significance of the spolia, have been developed in close collaboration with the Egyptian Ministry of Antiquities (Cairo and Aswan inspectorate) and installed at each block depot and at the entrance of the temple island (Figs. 81, 82). Another task was complementing the documentation of the block material. Seven reconstructed reliefs and the 84 most interesting spolia were copied by Pauline Calassou in facsimile.

In addition to its research and fieldwork, the project offered consulting to various companies producing documentary films about Philae; one of these filmed the mission at its work in the temples of Philae in November 2018.

Holger Kockelmann

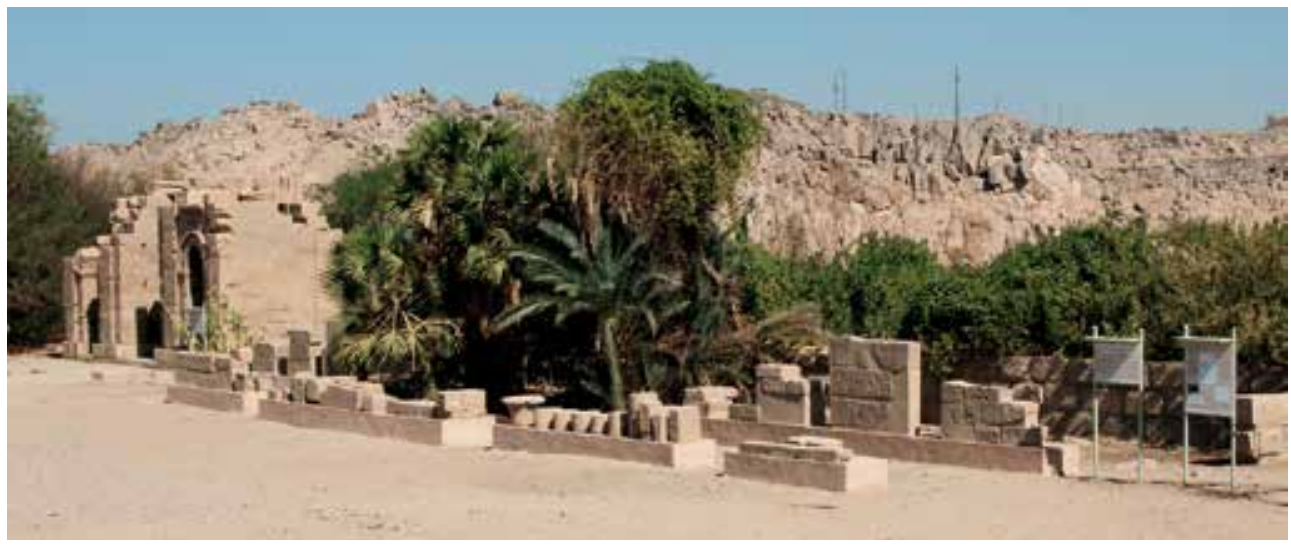

Fig. 81 The temple block depot in Agilkia north-east with Ramesside and Kushite spolia and remains of the earliest temple of Isis on Philae (photo/C H. Kockelmann)

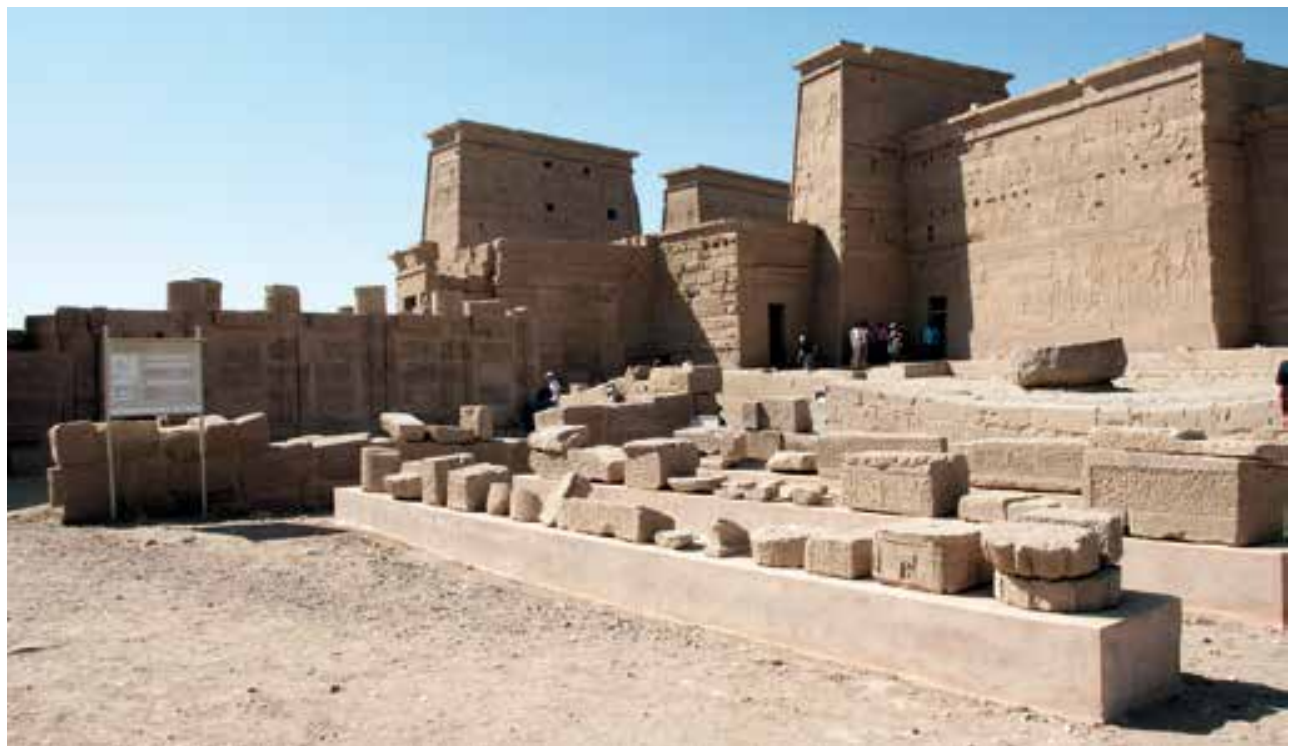

Fig. 82 The block storage area at the Temple of Hathor. In the background: the pylons and hypostyle hall of the temple of Isis (photo/C H. Kockelmann) 


\section{OREA-Team 2018}

Eva Alram-Stern

Patrick Aprent

Edeltraud Aspöck

David A. Aston

Bettina Bader

Marlon Bas

Sebastian Becker

Benedikt Biederer

Manfred Bietak

David Blattner

Dominik Bochatz

Mario Börner

Michael Brandl

Teresa Bürge

Clare Burke

Laura Burkhardt

Karl Burkhart

Ernst Czerny

Bibiana Dernec

Birgitta Eder

Thomas Einwögerer

Stefanie Fragner

Michaela Fritzl

Mario Gavranović

Silvia Gómez Senovilla

Monika Griebl

Roman Gundacker

Marc Händel
Irmtraud Hellerschmid

Felix Höflmayer

Barbara Horejs

Hermine Huber

Jasmin Huber

Lucia Hulková

Valentin Jovanovic

Reinhard Jung

Elefteria Kardamaki

Christian Knoblauch

Michael Konrad

Karin Kopetzky

Elke Kraft

Michaela Lochner

Nicola Math

Rosa Matic

Dagmar Melman

Bogdana Milić

Nicole Mittermair

Constanze Moser

Anna-Latifa Mourad

Sandra Müller

Vera Müller

Mohamad Mustafa

María Antonia Negrete Martínez

Felix Ostmann

Doris Pany-Kucera

Areti Pentedeka
Elisa Perego

Irene M. Petschko

Julian Posch

Sigrid Pratsch

Silvia Prell

Elisa Priglinger

Katharina Rebay-Salisbury

Barbara Rendl

Maria Röcklinger

Gabriela Ruß-Popa

Roderick Salisbury

Natalie Savic

Ulrike Schuh

Angela Schwab

Christoph Schwall

Martina Simon

Ulrich Simon

Michaela Spannagl-Steiner

Roswitha Thomas

Sarah Vilain

Lukas Waltenberger

Lyndelle Webster

Estella Weiss-Krejci

Annik Wüthrich

Michaela Zavadil

Sophie Zimmermann

\section{Guests and Associated Scientists 2018}

Buket Aydın
Yavuz Aydın
Katrin Bernhardt
Christopher Britsch
Norbert Buchinger
Julia Budka
Claudio Cavazzuti
Divina Centore
Ciler Çilingiroğlu
Christine de Vree
Sigrid Deger-Jalkotzy

Yana Dimitrova
Julie Dunne
Peter M. Fischer
Florian Fladerer
Herwig Friesinger
Stefan Grasböck
Manfred Hainzmann
Gizem Kartal
Metin Kartal
Neyir Kolankaya-Bostanc1
Ken Massy

Yana Dimitrova

Florian Fladerer

Herwig Friesinger

Stefan Grasböck

Manfred Hainzmann

Gizem Kartal

Neyir Kolankaya-Bostanc1

Ken Massy
Uroš Matić

Alba Masclans Latorre

Petar Minkov

Christine Neugebauer-Maresch

Annalisa Rumolo

Oliver Schmitsberger

Christophe Snoeck

Veronica Tamorri

Sinan Ünlüsöy

Jörg Weilhartner 


\section{OREA Publications 2018}

\section{Quaternary Archaeology}

T. Einwögerer, KG Kammern, Fundberichte aus Österreich 55, 2016, 2018, 215-216.

T. Einwögerer, Bericht über die Ausgrabungen an der paläolithischen Freilandstation in Kammern-Grubgraben 2016, Fundberichte aus Österreich 55, Wien 2018, D2639-D2654.

S. M. Groza - U. Hambach - D. Veres - A. Vulpoi - M. Händel - T. Einwögerer - U. Simon - C. Neugebauer-Maresch - A. Timar-Gabor, Optically stimulated luminescence ages for the Upper Palaeolithic site Krems-Wachtberg, Austria, Quaternary Geochronology, 2018. DOI: 10.1016/j.quageo.2018.04.005.

M. Händel, The stratigraphy of the Gravettian sites at Krems, Quartär 64, 2017, 129-155. http://dx.doi.org/10.7485/ QU64_6 (published 2018 with year 2017).

M. Händel - Krems-Wachtberg 2005-2015: The function of occupation horizon AH 4.4, in: S. Boriová - M. Novák - S. Sázelová (eds.), Mikulovský Antropologický Mítink II; 11. a 12. ř́jen 2018, Mikulov - Pavlov; Sborník abstraktů, Archeologický ústav AV ČR, Brno 2018, 24.

S. Meyer-Heintze - T. Sprafke - P. Schulte - B. Terhorst - J. Lomax - M. Fuchs - F. Lehmkuhl - C. Neugebauer-Maresch - T. Einwögerer - M. Händel - U. Simon - B. Solís-Castillo, The MIS 3/2 transition in a new loess profile at Krems-Wachtberg East - A multi-methodological approach, Quaternary International 464, Part B, 2018, 370-385. DOI: 10.1016/j.quaint.2017.11.048.

O. Schmitsberger - C. Neugebauer-Maresch, KG Grinzing u. a., 19. Bezirk u. a., Fundberichte aus Österreich 55, 2016, $2018,572-575$.

O. Schmitsberger - C. Neugebauer-Maresch, „Gog \& Magog - die Mammutjägerzeit in Wien“, Prospektionsprojekt zum Paläolithikum 2015 - 2016, Fundberichte aus Österreich 55, 2016, 2018, D8614-D8626.

O. Schmitsberger - C. Neugebauer-Maresch, „Rammkernsondierung Titlgasse“, Prospektionsprojekt zum Paläolithikum 2016, Fundberichte aus Österreich 55, 2016, Wien 2018, D8763-D8767.

U. Simon, Gravettian ivory beads at Krems-Wachtberg (Austria), in: Hugo Obermaier Society for Quaternary Research and Archaeology of the Stone Age, 60 $0^{\text {th }}$ Annual Meeting, April $3^{\text {rd }}-$ April $7^{\text {th }}$ 2018, Tarragona (Spain), 51-52.

\section{Prehistoric Phenomena}

St. Alexandrov - Y. Dimitrova - H. Popov - B. Horejs - K. Chukalev (eds.), Злато \& бронз / Gold \& Bronze. Metals, Technologies and Interregional Contacts in the Eastern Balkans during the Bronze Age (Sofia 2018).

E. Alram-Stern, The Mycenaean Bird Figurines from Kynos. Their Typology, Meaning and Function, in: M.-Ph. Pa-

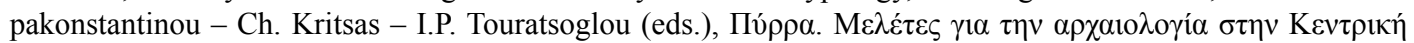

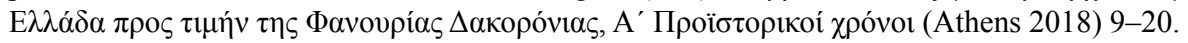

E. Alram-Stern, Visviki Magoula, Thessaly. Reconsidering Cultural Change from the Arapi- to the Dimini and Rachmani Phases, in: S. Dietz - F. Mavridis - Ž. Tankosić - T. Takaoğlu (eds.), Communities in Transition. The Circum-Aegean Area in the $5^{\text {th }}$ and $4^{\text {th }}$ Millennia BC (Oxford 2018) 217-227.

E. Alram-Stern, Early Helladic II Pottery from Midea in the Argolid. Forms and Fabrics Pointing to Special Use and Import, in: E. Alram-Stern - B. Horejs (eds.), Pottery Technologies and Sociocultural Connections Between the Aegean and Anatolia During the $3^{\text {rd }}$ Millennium BC, Oriental and European Archaeology 10 (Vienna 2018) $161-181$

E. Alram-Stern - B. Horejs (eds.), Pottery Technologies and Sociocultural Connections between the Aegean and Anatolia during the $3^{\text {rd }}$ Millennium BC, Oriental and European Archaeology 10 (Vienna 2018).

C. Burke - P. M. Day - E. Alram-Stern - K. Demakopoulou - A. Hein, Crafting and Consumption Choices. Neolithic Early Helladic II Ceramic Production and Distribution, Midea and Tiryns, Mainland Greece, in: E. Alram-Stern - B. Horejs (eds.), Pottery Technologies and Sociocultural Connections between the Aegean and Anatolia during the $3^{\text {rd }}$ Millennium BC, Oriental and European Archaeology 10 (Vienna 2018) 145-159. 
S. Felkel-C. Vogl-D. Rigler-V. Jagannathan-T. Leeb-R. Fries-M. Neuditschko-S. Rieder-B. Velie-G. LindgrenC.J. Rubin - C. Schlötterer - T. Rattei - G. Brem - B. Wallner, Asian horses deepen the MSY phylogeny, Animal Genetics 49, 1, 2018, 90-93.

C. Gaunitz-A. Fages-K. Hanghøj-A. Albrechtsen-N. Khan-M. Schubert-A. Seguin-Orlando-I. J. Owens-S. FelkelO. Bignon-Lau-P. de Barros Damgaard-A. Mittnik-A. F. Mohaseb-H. Davoudi-S. Alquraishi-A. H. AlfarhanK. A. S. Al-Rasheid - E. Crubézy - N. Benecke - S. Olsen - D. Brown - D. Anthony - K. Massy - V. Pitulko A. Kasparov - G. Brem - M. Hofreiter - G. Mukhtarova - N. Baimukhanov - L. Lõugas - V. Onar - P. W. Stockhammer - J. Krause - B. Boldgiv - S. Undrakhbold - D. Erdenebaatar - S. Lepetz - M. Mashkour - A. Ludwig - B. Wallner - V. Merz - I. Merz - V. Zaibert - E. Willerslev - P. Librado - A. K. Outram - L. Orlando, Ancient genomes revisit the ancestry of domestic and Przewalski's horses. Science 360, 6384, 2018, 111-114.

B. Horejs - Ch. Schwall - V. Müller - M. Luciani - M. Ritter - M. Guidetti - R. B. Salisbury - F. Höflmayer - T. Bürge (eds.), Proceedings of the $10^{\text {th }}$ International Congress on the Archaeology of the Ancient Near East, $25^{\text {th }}-29^{\text {th }}$ April 2016, Vienna, vols. 1-2 (Wiesbaden 2018).

B. Horejs, OREA. The Institute for Oriental and European Archaeology, Austrian Academy of Sciences, IANSA IX, 2018, 1, 2018, 103-108.

B. Horejs, Die Bronzezeit. Anfänge und Dynamik einer neuen Epoche, in: Badisches Landesmuseum Karlsruhe (eds.), Mykene. Die sagenhafte Welt des Agamemnon, Sonderausstellung des Badischen Landesmuseums Karlsruhe in Kooperation mit dem Ministerium für Kultur und Sport der Republik Griechenland im Schloss Karlsruhe, vom 1. Dezember 2018 bis 2. Juni 2019 (Darmstadt 2018) 58-60.

B. Horejs - A. Bulatović - C. Meyer - B. Milić - St. Schneider - M. Schlöffel - V. Stevanović, Prehistoric Landscapes of the Pusta Reka River (Leskovac). New investigations along the Southern Morava River, Journal of Serbian Archaeological Society 34, 2018, 23-51.

B. Horejs - S. Japp - H. Mommsen, Early Bronze Age Pottery Workshops around Pergamon. A Model for Pottery Production in the $3^{\text {rd }}$ Millennium BC, in: E. Alram-Stern - B. Horejs (eds.), Pottery Technologies and Sociocultural Connections between the Aegean and Anatolia during the $3^{\text {rd }}$ Millennium BC, Oriental and European Archaeology 10 (Vienna 2018) 25-61.

B. Horejs - Ch. Schwall, Interaction as a stimulus? Çukuriçi Höyük and the transition from the Late Chalcolithic period to the Early Bronze Age in Western Anatolia, in: S. Dietz - F. Mavridis - Ž. Tankosić - T. Takaoğlu (eds.), Communities in Transition. The Circum-Aegean Area in the $5^{\text {th }}$ and $4^{\text {th }}$ Millennia BC, Monographs of the Danish Institute at Athens 20 (Oxford 2018) 530-537.

P. Pavúk - B. Horejs, Ceramics, Surveys, and Connectivity in Western Anatolia. The Middle and Late Bronze Age Bakırçay/Kaikos Valley Restudied, Ägypten und Levante 28, 2018, 457-486.

L. Peloschek, Marble-Tempered Ware in $3^{\text {rd }}$ Millennium BC Anatolia, in: E. Alram-Stern - B. Horejs (eds.), Pottery Technologies and Sociocultural Connections between the Aegean and Anatolia during the $3^{\text {rd }}$ Millennium BC, Oriental and European Archaeology 10 (Vienna 2018) 63-76.

M. Röcklinger - B. Horejs, Function and Technology. A Pottery Assemblage from an Early Bronze Age House at Çukuriçi Höyük, in: E. Alram-Stern - B. Horejs (eds.), Pottery Technologies and Sociocultural Connections between the Aegean and Anatolia during the $3^{\text {rd }}$ Millennium BC, Oriental and European Archaeology 10 (Vienna 2018) 77-104.

Ch. Schwall, Çukuriçi Höyük 2. Das 5. und 4. Jahrtausend v. Chr. in Westanatolien und der Ostagäis (mit einem Beitrag von B. Horejs), Oriental and European Archaeology 7 (Wien 2018).

Ch. Schwall, Rezension zu: Irina Gambashidze, Thomas Stöllner, (eds.), The Gold of Sakdrisi: Man‘s First Gold Min-

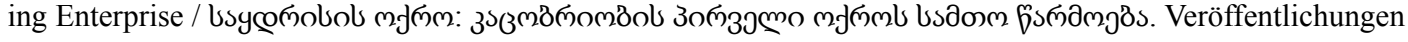
aus dem Deutschen Bergbau-Museum Bochum 211. VML Verlag Marie Leidorf, Rahden/Westf. 2016, 174 pages, ca. 400 color figures, hardcover, ISBN 978-3-86757-011-4, Archaeologia Austriaca 102, 2018, 256-260.

Ch. Schwall - B. Horejs, Permanent or Seasonal? Evidence of Settlements in Late Chalcolithic Western Anatolia, in: B. Horejs - Ch. Schwall - V. Müller - M. Luciani - M. Ritter - M. Guidetti - R. B. Salisbury - F. Höflmayer - T. Bürge (eds.), Proceedings of the $10^{\text {th }}$ International Congress on the Archaeology of the Ancient Near East, $25^{\text {th }}-29^{\text {th }}$ April 2016, Vienna, vol.1 (Wiesbaden 2018) 57-68.

\section{Prehistoric Identities}

C. Haselgrove - P. S. Wells - K. Rebay-Salisbury (eds.), The Oxford Handbook of the European Iron Age (Oxford 2018).

B. Horejs - Ch. Schwall - V. Müller - M. Luciani - M. Ritter - M. Guidetti - R. B. Salisbury - F. Höflmayer - T. Bürge (eds.), Proceedings of the $10^{\text {th }}$ International Congress on the Archaeology of the Ancient Near East, $25^{\text {th }}-29^{\text {th }}$ April 2016, Vienna, vols. 1-2 (Wiesbaden 2018). 
D. Pany-Kucera - M. Berner - H. Reschreiter - A. Kern - K. Kowarik, Chronische Entzündungen der Nasennebenhöhlen als Hinweis auf die Umweltbedingungen im eisenzeitlichen Hallstatt, in: J. Drauschke - E. Kislinger - K. Kühtreiber - T. Kühtreiber - G. Scharrer-Liska - T. Vida (eds.), Lebenswelten zwischen Archäologie und Geschichte. Festschrift für Falko Daim zu seinem 65. Geburtstag. Monographien des RGZM 150 (Mainz 2018) 985-995.

E. Perego - R. Scopacasa, The Agency of the Displaced? Roman Expansion, Environmental Forces, and the Occupation of Marginal Landscapes in Ancient Italy. Humanities 7, 2018, article 116.

K. Rebay-Salisbury, Horses, wagons and chariots, in: C. Haselgrove - P. S. Wells - K. Rebay-Salisbury (eds.), The Oxford Handbook of the European Iron Age. Oxford Handbooks Online (Oxford 2018).

K. Rebay-Salisbury, Personal relationships between co-buried individuals in the central European Early Bronze Age, in: G. Lillehammer - E. Murphy (eds.), Across the Generations: The Old and the Young in Past Societies. Childhood in the Past Monograph Series 8 (Stavanger 2018) 35-48.

K. Rebay-Salisbury, Vielversprechende Ansätze und kleine Irrwege: die Interpretationsgeschichte frühbronzezeitlicher Bestattungen am Beispiel Schleinbach, in: F. Pieler - P. Trebsche (eds.), Beiträge zum Tag der Niederösterreichischen Landesarchäologie 2018 (Asparn 2018) 45-56.

K. Rebay-Salisbury - D. Pany-Kucera - M. Spannagl-Steiner - F. Kanz - P. Galeta - M. Teschler-Nicola - R. B. Salisbury, Motherhood at early Bronze Age Unterhautzenthal, Lower Austria. Archaeologia Austriaca 102, 2018, 71-134.

R. B. Salisbury, European Year for Cultural Heritage: An Opportunity for Archaeology and Archaeological Heritage Public Policies. The European Archaeologist 56, 2018, 15-16.

M. Teschler-Nicola - F. Novotny - U. M. Spannagl-Steiner - E. Haring - J. Irrgeher - A. Zitek - K. Rumpelmayr E. M. Wild - B. Tautscher - T. Prohaska, Die frühmittelalterlichen Fundstellen von Thunau am Kamp (NÖ) und ihre bioanthropologischen Evidenzen - eine Zusammenfassung, in: E. Nowotny - M. Obenaus - S. UzunogluObenaus (eds.), 50 Jahre Archäologie in Thunau am Kamp. Festschrift für Herwig Friesinger. Archäologische Forschungen in Niederösterreich 5 (Asparn 2018) 219-240.

K. Wiltschke-Schrotta - D. Pany-Kucera, Poster: Planning Ahead - artificial cranial deformation: an exceptional form of childcare (Vienna 2018).

V. Zanoni - M. Saracino - E. Perego - L. Zamboni, Crossing places. Luoghi di passaggio e resti umani nella protostoria dell'Italia nord-orientale, in: V. Nizzo (ed.), Archeologia e antropologia della morte. Atti del III incontro di studi di archeologia e antropologia a confronto (Roma 2018).

\section{Poster Publications Prehistoric Identities}

M. Bas, Poster: A preliminary analysis of the Paleopathology and Dental Microwear in deceased children from an Early Bronze-Age community in Lower Austria (Vienna 2018).

M. Fritzl, Poster: Graves within a circular ditch: A grave architecture predominantly used for child burials in Inzersdorf ob der Traisen? (Vienna 2018).

F. Novotny - U. M. Spannagl-Steiner - A. C. von Miller, Poster: An unusual bi-ritual burial of the Urnfield Culture in Lower Austria. 22 ${ }^{\text {nd }}$ European meeting of the Paleopathology Association (Zagreb 2018).

D. Pany-Kucera - M. Spannagl-Steiner - K. Rebay-Salisbury, Poster: The "auriculate extension": a new indicator of pregnancy and childbirth at the sacrum? (Austin, Texas, USA 2018).

D. Pany-Kucera - U. M. Spannagl-Steiner - K. Rebay-Salisbury, Poster: Extracting obstetric histories from pelvic features (Zagreb 2018).

V. Tamorri - E. Perego, Poster: Coffin birth or post-mortem foetal extrusion: an on-going archaeological debate (Vienna 2018).

\section{DEEPDEAD - Deploying the Dead: Artefacts and human bodies in socio-cultural transformations}

M. Binder-E. Weiss-Krejci, Zu den postmortalen Eingriffen am Skelett: Hinweis auf eine intentionelle Zerkleinerung?, in: M. Binder - S. Ladstätter (eds.), Die Heilige vom Hemmaberg - Cold Case einer Reliquie (Vienna 2018) 95-105.

K. Mandl - F. Novotny - M. Teschler-Nicola - E. Weiss-Krejci, The corpse in the Early Bronze Age: results of histotaphonomic and archaeothanatological investigations of human remains from the Cemetery of Franzhausen I, Lower Austria, Archaeologia Austriaca 102, 2018, 135-167. 
R. B. Salisbury - K. Rebay-Salisbury - E. Weiss-Krejci, Disciplinarity in Archaeology, 4th Annual Central Europe TAG (Theoretical Archaeology Group). Vienna, 16-17 October 2017. Conference and Workshop Reports, The European Archaeologist (TEA) 55, 2018, 14-16.

E. Weiss-Krejci, Book review of 'Mortuary Landscapes of the Classic Maya: Rituals of Body and Soul', Latin American Antiquity 29, 2018, 200-202.

E. Weiss-Krejci, Foreword, in: N. Seefeld, The Hydraulic System of Uxul. Origins, Functions, and Social Setting, Archaeopress Precolumbian Archaeology 9 (Oxford 2018) xv.

E. Weiss-Krejci, Märtyrer, Heilige und Körperreliquien in der frühchristlichen Welt, in: M. Binder - S. Ladstätter (eds.), Die Heilige vom Hemmaberg - Cold Case einer Reliquie (Vienna 2018) 137-147.

E. Weiss-Krejci, Who is who in the grave? A cross-cultural approach, in: A. Schmitt - S. Déderix - I. Crevecoeur (eds.), Gathered in Death. Archaeological and Ethnological Perspectives on Collective Burial and Social Organisation, Aegis: Actes de Colloques 14 (Louvain-la-Neuve 2018) 107-123.

E. Weiss-Krejci - B. Horejs, Editorial, Archaeologia Austriaca 102/2018, 7-8.

\section{Levantine and Egyptian Histories}

R. Gundacker, Where to place 'Ältere Komposita'? Traces of Dialectal Diversity among Early Toponyms and Theonyms, in: D. A. Werning (ed.), Proceedings of the Fifth International Conference on Egyptian-Coptic Linguistics (Crossroads V), Berlin, February 17-20, 2016, Lingua Aegyptia 25 (Hamburg 2018) 101-176.

R. Gundacker, Retention or Rejection: The Fate of 'Ältere Komposita' at the Transition from the 'Dreisilbengesetz' to the 'Zweisilbengesetz', in: A. Kahlbacher - E. Priglinger (Eds.), Tradition and Transformation in Ancient Egypt. Proceedings of the $5^{\text {th }}$ International Congress for Young Egyptologists, Vienna, $15^{\text {th }}$ to $19^{\text {th }}$ September 2015 , Contributions to the Archaeology of Egypt, Nubia and the Levant 6 (Vienna 2018) 159-194.

R. Gundacker, The Descent of Kawab and Hetepheres II, Göttinger Miszellen, Beiträge zur ägyptologischen Diskussion 256, 2018, 65-91.

R. Gundacker, Zu Lesung und Bedeutung von PT 1 § 1a T. Grammatik und Morphologie im Zusammenspiel mit Struktur und Stilistik, Lingua Aegyptia, Journal of Egyptian Language Studies 26, 2018, 103-150.

R. Gundacker, Review: Marc Brose, Grammatik der dokumentarischen Texte des Mittleren Reiches, Lingua Aegyptia Studia Monographica 13, Hamburg: Widmaier Verlag 2014, Die Welt des Orients 48, 2018, 157-171.

F. Höflmayer, An Early Date for Khyan and Its Implications for Eastern Mediterranean Chronologies, in: I. Forstner-Müller - N. Moeller (eds.), The Hyksos Ruler Khyan and the Early Second Intermediate Period in Egypt: Problems and Priorities of Current Research. Proceedings of the Workshop of the Austrian Archaeological Institute and the Oriental Institute of the University of Chicago, Vienna, July 4-5, 2014, Ergänzungsheft zu den Jahresheften des Österreichischen Archäologischen Institutes in Wien 17 (Wien 2018) 143-171.

F. Höflmayer, Review: Fremdes in Anatolien. Importgüter aus dem Ostmittelmeerraum und Mesopotamien als Indikator für spätbronzezeitliche Handels- und Kulturkontakte von Ekin Kozal, Wiener Zeitschrift für die Kunde des Morgenlandes 108, 2018, 330-334.

F. Höflmayer - A. A. Burke - B. N. Damiata - J. R. Southon - E. M. Wild - P. Steier - P. M. Fischer, Radiocarbon, in: P. M. Fischer - T. Bürge (eds.), Two Late Cypriot City Quarters at Hala Sultan Tekke. The Söderberg Expedition 2010-2017, Studies in Mediterranean Archaeology 147 (Uppsala 2018) 595-602.

F. Höflmayer - K. Streit, The Impact of Radiocarbon Dating and Absolute Chronology in the Holy Land: A Social Archaeological Perspective, in: A. Yasur-Landau - E. H. Cline - Y. M. Rowan (eds.), The Social Archaeology of the Levant: From Prehistory to the Present (Cambridge 2018) 573-593.

B. Horejs - Ch. Schwall - V. Müller - M. Luciani - M. Ritter - M. Guidetti - R. B. Salisbury - F. Höflmayer - T. Bürge (eds.), Proceedings of the $10^{\text {th }}$ International Congress on the Archaeology of the Ancient Near East, $25^{\text {th }}-29^{\text {th }}$ April 2016, Vienna, vols. 1-2 (Wiesbaden 2018).

K. Streit, Beyond the Image. Composite Female Figurines and Gender Relations of the Near East in the Mid-Sixth Mill. Cal. B.C.E., Zeitschrift des Deutschen Palästina-Vereins 134 (1), 2018, 1-27.

K. Streit - L. Webster - V. Becker - A.-K. Jeske - H. Misgav - F. Höflmayer, Between Destruction and Diplomacy in Canaan: The Austro-Israeli Expedition to Tel Lachish, Near Eastern Archaeology 81 (4), 2018, 259-268.

L. Webster - O. Sergi - S. Kleiman - O. Lipschits - Q. Hua - G. E. Jacobsen - Y. Tristant - Y. Gadot, Preliminary Radiocarbon Results for Late Bronze Age Strata at Tel Azekah and Their Implications, Radiocarbon 60 (1), 2018, 309-331. 


\section{Material Culture in Egypt and Nubia}

B. Bader, On Simple House Architecture at Tell el-Daba and its Parallels in the late Middle Kingdom, Ägypten und Levante 28, 2018, 111-146.

L. Hulková - M.H.M Ahmed - S.A.E. Hashem - A. Wodzińska, Egyptian Salvage Excavations at Tell el-Mansheya, Ägypten und Levante 28, 2018, 55-84.

C. Knoblauch - E.C. Köhler, III. 2. Die Keramik vom B-Friedhof, Abydos, Mitteilungen des Deutschen Archäologischen Instituts, Abteilung Kairo 73, 2018, 23-35.

C. Knoblauch, The Late Middle Kingdom in the Cemeteries at Mirgissa. Pottery and Relative Chronology, Cahier de la Ceramique Egyptienne 11, 2018, 47-72.

U. Matić, De-colonizing historiography and archaeology of ancient Egypt and Nubia Part 1. Scientific Racism, Journal of Egyptian History 11, 2018, 19-44.

U. Matić, "Execration" of Nubians in Avaris: A case of mistaken ethnic identity and hidden archaeological theory, Journal of Egyptian History 11, 2018, 87-112.

J. Sigl - B. Bader - M. Fielauf - C. Jeuthe, - E. Laskowska-Kusztal - P. Kopp - C. Malleson - M.-C. Schröder C. Von Pilgrim, Elephantine - Report on the $47^{\text {th }}$ season: Report on the Excavations at Elephantine by the German Archaeological Institute and the Swiss Institute from autumn 2017 to summer 2018, 2018, https://www. dainst.org/project/25953/.

\section{Tell el-Daba Publications}

D. Aston, How Early (and How Late) can Khyan really be? An Essay based on "Conventional Archaeological Methods", in: I. Forstner-Müller - N. Moeller (eds.), The Hyksos Ruler Khyan and the early Second Intermediate Period in Egypt: Problems and Priorities of Current Research. Ergänzungshefte zu den Jahresheften des Österreichischen Archäologischen Institutes 17 (Vienna 2018) 15-55.

B. Bader, On Simple House Architecture at Tell el-Daba and its Parallels in the late Middle Kingdom, Ägypten und Levante 28, 2018, 111-146.

E. Czerny - M. Bietak, Preface, Ägypten und Levante 28, 2018, 13-16.

B. Horejs - Ch. Schwall - V. Müller - M. Luciani - M. Ritter - M. Guidetti - R. B. Salisbury - F. Höflmayer - T. Bürge (eds.), Proceedings of the $10^{\text {th }}$ International Congress on the Archaeology of the Ancient Near East, $25^{\text {th }}-29^{\text {th }}$ April 2016, Vienna, vols. 1-2 (Wiesbaden 2018).

K. Kopetzky, Storage jars found in Middle Bronze Age Ashkelon, in: L. E. Stager - J. D. Schloen - R. J. Voss (eds.), Ashkleon 6. The Middle Bronze Age Ramparts and Gates of the North Slope and Later Fortifications (University Park 2018) 209-236.

K. Kopetzky, Tell el-Dabca and Byblos - New chronological evidence, Ägypten und Levante 28, 2018, 313-362.

V. Müller, VII.1. Beschriftete Keramik und neue Festsiegel, in: G. Dreyer et al., Umm el-Qaab - Nachuntersuchungen im frühzeitlichen Königsfriedhof. 25./26./27. Vorbericht, Mitteilungen des Deutschen Archäologischen Instituts Kairo 73, 2017 (published 2018), 67-75.

V. Müller, Chronological Concepts for the Second Intermediate Period and Their Implications for the Evaluation of Its Material Culture, in: I. Forstner-Müller - N. Moeller (eds.), The Hyksos Ruler Khyan and the early Second Intermediate Period in Egypt: Problems and Priorities of Current Research. Ergänzungshefte zu den Jahresheften des Österreichischen Archäologischen Institutes 17 (Vienna 2018) 199-216.

V. Müller, Gedanken zur Beigabe von (Modell)Speichern in Grabkontexten der ägyptischen Frühzeit, in: A. I. Blöbaum - M. Eaton-Krauss - A. Wütherich (eds.), Pérégrinations avec Erhart Graefe - Festschrift zu seinem 75. Geburtstag. Ägypten und Altes Testament 87 (Münster 2018) 405-419.

\section{Mediterranean Economies}

T. Bürge, Late Bronze Age Offering Pits from Hala Sultan Tekke, Cyprus: Diachronic Perspectives of Activities, Ceremonies and Rituals in a Suburban Area, in: B. Horejs - Ch. Schwall - V. Müller - M. Luciani - M. Ritter - M. Guidetti - R. B. Salisbury - F. Höflmayer - T. Bürge (eds.), Proceedings of the $10^{\text {th }}$ International Congress on the Archaeology of the Ancient Near East, $25^{\text {th }}-29^{\text {th }}$ April 2016, Vienna, vol. 1 (Wiesbaden 2018) 209-220. 
T. Bürge - P. M. Fischer, The Early Iron Age at Tell Abu al-Kharaz, Jordan Valley and its Relations to the Eastern Mediterranean: Trade, Migration, Hybridization, and Other Phenomena, in: Ł. Niesiołowski-Spanò - M. Węcowski (eds.), Change, Continuity, and Connectivity. North-Eastern Mediterranean at the Turn of the Bronze Age and in the Early Iron Age, Philippika. Altertumswissenschaftliche Abhandlungen 118 (Wiesbaden 2018) 169-193.

T. Bürge - P. M. Fischer, New Insights on Burial Practices at the Late Bronze Age City of Hala Sultan Tekke, Cyprus, Ugarit-Forschungen 48/2017, 2018, 121-171.

T. Bürge - P. M. Fischer, Ivory at the Transition from the Late Bronze to the Early Iron Age in Transjordan: Trade and Distribution, in: B. Horejs - Ch. Schwall - V. Müller - M. Luciani-M. Ritter-M. Guidetti-R. B. Salisbury - F. Höflmayer - T. Bürge (eds.), Proceedings of the $10^{\text {th }}$ International Congress on the Archaeology of the Ancient Near East, $25^{\text {th }}-29^{\text {th }}$ April 2016, Vienna, vol. 2 (Wiesbaden 2018) 261-273.

P. M. Fischer - T. Bürge, Two Late Cypriot City Quarters at Hala Sultan Tekke. The Söderberg Expedition 2010-2017, Studies in Mediterranean Archaeology 147 (Uppsala 2018).

P. M. Fischer - T. Bürge, The New Swedish Cyprus Expedition 2017: Excavations at Hala Sultan Tekke (The Söderberg Expedition). Preliminary Results, Opuscula. Annual of the Swedish Institutes in Athens and Rome 11, 2018, $29-79$.

P. M. Fischer - T. Bürge, A Levantine Vessel from a Late Cypriot Tomb at Hala Sultan Tekke, in: I. Shai - J. R. Chadwick - L. A. Hitchcock - A. Dagan - C. McKinny - J. Uziel (eds.), Tell it in Gath. Studies in the History and Archaeology of Israel: Essays in Honor of Aren M. Maeir on the Occasion of his Sixtieth Birthday, Ägypten und Altes Testament 90 (Münster 2018) 194-205.

B. Horejs - R. Jung, Networks and Cultural Contacts with the Aegean, in: St. Alexandrov - Y. Dimitrova - H. Popov - В. Horejs - K. Chukalev (eds.), Злато \& Бронз / Gold \& Bronze. Metals, Technologies and Interregional Contacts in the Eastern Balkans during the Bronze Age (Sofia 2018) 233-240.

B. Horejs - Ch. Schwall - V. Müller - M. Luciani - M. Ritter - M. Guidetti - R. B. Salisbury - F. Höflmayer - T. Bürge (eds.), Proceedings of the $10^{\text {th }}$ International Congress on the Archaeology of the Ancient Near East, $25^{\text {th }}-29^{\text {th }}$ April 2016, Vienna, vols. 1-2 (Wiesbaden 2018).

R. Jung, Mycenaean Pottery in coastal Syria, in: L. Badre - E. Capet - B. Vitale (eds.), Tell Kazel au Bronze récent. Études céramiques, Bibliothèque Archéologique et Historique 211 (Beirut 2018) 47-51; 148-155.

R. Jung, Late Bronze Age Trojan Grey Ware Pottery from Sidon - Interpretation, Archaeology and History in Lebanon 48-49, 2018-2019, 117-122.

R. Jung, Push and Pull Factors of the Sea Peoples between Italy and the Levant, in: J. Driessen (ed.), An Archaeology of Forced Migration. Crisis-induced Mobility and the Collapse of the $13^{\text {th }} \mathrm{c}$. BCE Eastern Mediterranean, Aegis 15 (Louvain-la-Neuve 2018) 273-306.

R. Jung, Warriors and Weapons in the Central and Eastern Balkans, in: St. Alexandrov - Y. Dimitrova - H. Popov B. Horejs - K. Chukalev (eds.), Злато \& Бронз / Gold \& Bronze. Metals, Technologies and Interregional Contacts in the Eastern Balkans during the Bronze Age (Sofia 2018) 241-252.

R. Jung, Inferno in der Bronzezeit. Das Ende der ostmediterranen Königreiche, in: Mykene - Die sagenhafte Welt des Agamemnon. Exhibition Catalog Karlsruhe (Karlsruhe, Darmstadt 2018) 230-233.

E. Kardamaki, Book review: P. A. Mountjoy, Troy VI Middle, VI Late and VII: The Mycenaean Pottery. Studia Troica Monographien 9 (Bonn 2017), Archaeologia Austriaca 102, 2018, 265-269.

E. Kardamaki - K. Kaza-Papageorgiou, Change and continuity in the pottery tradition at Kontopigado, Alimos, during the late $13^{\text {th }}$ and the early $12^{\text {th }}$ c. BC., in: I. Caloi - Ch. Langohr (eds.), Technology in Crisis. Technological changes in ceramic production during periods of trouble, Aegis 16 (Louvain-la-Neuve 2018) 111-138.

K. Kaza-Papageorgiou - E. Kardamaki, A LH IIIA1 deposit from Kontopigado, Alimos and Processes of Mycenaeanization at Athens, Athenische Mitteilungen 133, 2018, 1-58.

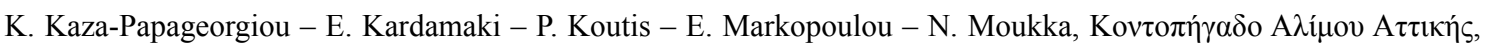
Archaeologike Ephemeris (Athens 2018).

Ch. Kleitsas - M. Mehofer - R. Jung, The Late Bronze Age Hoard of Stephani in Preveza, Epirus, NW Greece, Archäologischer Anzeiger 2018/1, 73-107.

D. Kofel - T. Bürge, Agriculture and Storage Practices in an Early Iron Age Household: Analyses of Plant Macro Remains at Tell Abu Al-Kharaz, Jordan Valley, Ägypten und Levante 28, 2018, 291-308.

\section{Mycenaean Aegean}

E. Alram-Stern, The Mycenaean bird figurines from Kynos. Their typology, meaning and function, in: M.-Ph. Papakon-

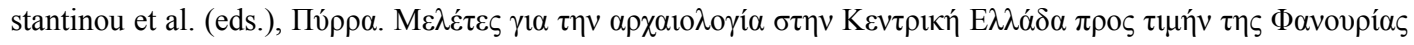

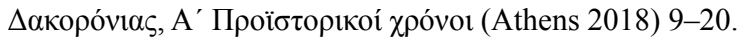


K. Bernhardt, Mycenaean imports to Crete: Some thoughts on the interrelations between the Greek mainland and

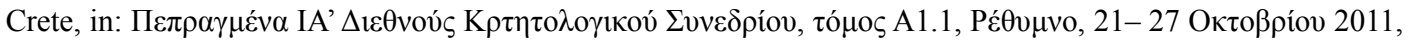
Rethymnon 2018, 87-98.

S. Deger-Jalkotzy, Geometric pottery from Elateia-Alonaki. The end of a long history, in: M.-Ph. Papakonstantinou et

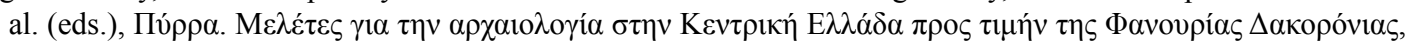

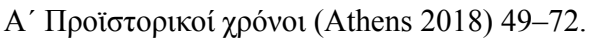

S. Deger-Jalkotzy - D. Hertel, Das mykenische Griechenland: Geschichte, Kultur, Stätten, C.H. Beck Reihe Wissen (Munich 2018).

B. Eder, Elis und Olympia. Die Genese zweier Zentren einer Landschaft, Habilitation thesis Technical University of Darmstadt 2018.

B. Eder, Hoch hinaus und gut vernetzt: Die frühmykenischen Eliten von Kakovatos, in: Badisches Landesmuseum (ed.), „Mykene. Die sagenhafte Welt des Agamemnon“, Katalog zur Sonderausstellung 30. November 2018-02. Juni 2019 im Badischen Landesmuseum in Karlsruhe (Darmstadt 2018), 90-94.

B. Eder, Katalogeinträge: Nr. 48 Amethystperlen, Nr. 49 Schmuckperlen, in: Badisches Landesmuseum (ed.), „Mykene. Die sagenhafte Welt des Agamemnon“, Katalog zur Sonderausstellung 30. November 2018-02. Juni 2019 im Badischen Landesmuseum in Karlsruhe (Darmstadt 2018), 279.

B. Eder, Starthilfe von der Insel Kreta, Damals 12, 2018, 22-25.

B. Eder, 2.5.1. Overview: Greece and Greeks in the Mediterranean world, in: A. M. Wittke (ed.) Brill's New Pauly Supplements 9: The Early Mediterranean World, 1200-600 BC (Leiden - Boston 2018) 209-216.

B. Eder, 2.5.11. Olympia, in: A. M. Wittke (ed.) Brill's New Pauly Supplements 9: The Early Mediterranean World, 1200-600 BC (Leiden - Boston 2018) 246-248.

B. Eder, 2.5.9. Peloponnese, in: A. M. Wittke (ed.) Brill's New Pauly Supplements 9: The Early Mediterranean World, 1200-600 BC (Leiden - Boston 2018) 238-244.

B. Eder - St. Gimatzidis, 2.5.3. Northwestern Greece, in: A. M. Wittke (ed.) Brill's New Pauly Supplements 9: The Early Mediterranean World, 1200-600 BC (Leiden - Boston 2018) 220-222.

St. Gimatzidis - B. Eder, 2.5.16. Aegean networks in the Mediterranean, in: A. M. Wittke (ed.) Brill's New Pauly Supplements 9: The Early Mediterranean World, 1200-600 BC (Leiden - Boston 2018) 258-263.

J. Huber, Katalogeinträge: Nr. 42: Applikation in Form einer Eule, Nr. 45-46: Palatiale Amphoren, in: Badisches Landesmuseum (ed.), Mykene. Die sagenhafte Welt des Agamemnon“, Katalog zur Sonderausstellung 30. November 2018-02. Juni 2019 im Badischen Landesmuseum in Karlsruhe (Darmstadt 2018), 277-278.

L. Obrocki - B. Eder - H.-J. Gehrke - E. I. Kolia - F. Lang - A. Vött - T. Willershäuser - P. Fischer - G. ChatziSpiliopoulou - K. Rusch - D. Wilken - E.-I. Kolia - O. Vikatou, Detection and localization of chamber tombs in the environs of ancient Olympia (Peloponnese, Greece) based on a combination of archaeological survey and geophysical prospection using electrical resistivity tomography (ERT), Geoarchaeology 2019, 1-13. DOI: 10.1002/gea.21724.

J. Weilhartner, Eine animalische Kopulationsszene aus dem frühen Kreta: Bronzezeitlich oder Früheisenzeitlich?, in: R. Kastler - F. Lang - H. Wendling (eds.), Faber Salisburgi. Festschrift für Wilfried K. Kovacsovics zum 65. Geburtstag, Salzburg Studien 18 = ArchaeoPlus 18 (Salzburg 2018) 351-358.

J. Weilhartner, The Missing Mother. Zur fehlenden Darstellung stillender Mütter in der minoischen Bilderwelt, Forum Archaeologiae 86/III/2018 (http://farch.net).

J. Weilhartner, Entzifferung von Linear B: Michael Ventris, in: Badisches Landesmuseum (eds.), „Mykene. Die sagenhafte Welt des Agamemnon“, Katalog zur Sonderausstellung 30. November 2018-02. Juni 2019 im Badischen Landesmuseum in Karlsruhe (Darmstadt 2018) 47-48.

J. Weilhartner - M. Vetters, Conceptions of Gender and Body Images in the Aegean World and East Mediterranean Societies in the Late Bronze Age, in: B. Horejs - Ch. Schwall - V. Müller - M. Luciani - M. Ritter - M. Guidetti - R. B. Salisbury - F. Höflmayer - T. Bürge (eds.), Proceedings of the $10^{\text {th }}$ International Congress on the Archaeology of the Ancient Near East, $25^{\text {th }}-29^{\text {th }}$ April 2016, Vienna, vol.1 (Wiesbaden 2018) 551-562.

\section{Urnfield Culture Networks}

B. Biederer, Verteilungsmuster spätbronzezeitlicher Speichergruben in Mitteleuropa, Archaeologica Austriaca 102, 2018, 169-199. 
M. Gavranović, No group, no people? Archeological record and creation of the groups in the western Balkans, in: S. Gimatzidis - M. Pieniążek - S. Votruba (eds.), Archaeology across Frontiers and Borderlands. Fragmentation and Connectivity in the North Aegean and the Central Balkans from the Bronze Age to the Iron Age, Oriental and European Archeology, Oriental and European Archaeology 9, 427-447.

M. Gavranović - A. Sejfuli, The Early Iron Age in Central Bosnia - overview and research perspectives, Proceedings of the first PEBA Conference "The Early Iron Age: Methods and Approaches" National Museum in Sarajevo, (8th-9th April 2016), Godišnjak Centra za balkanološka ispitivanja 48, Sarajevo 2018, 27-45.

\section{Raw Material Lab}

M. Brandl - C. Hauzenberger, Geochemical Sourcing of Lithic Raw Materials from Secondary Deposits in South Serbia. Implications for Early Neolithic Resource Management Strategies, Archaeologia Austriaca 102, 2018, 55-70.

M. Brandl - M. M. Martinez - C. Hauzenberger - P. Filzmoser - P. Nymoen - N. Mehler, A multi-technique analytical approach to sourcing Scandinavian flint: Provenance of ballast flint from the shipwreck aLeirvigen $1^{\circ}$, Norway, PLOS ONE 13(8), 2018: e0200647. https://doi.org/10.1371/journal.pone.0200647

M. Brandl - O. Schmitsberger - G. Trnka, News from the Eastern Fringe - The Baunzen Site near Vienna, Austria, in: D. H. Werra - M. Woźny (eds.), Between History and Archaeology. Papers in Honour of Jacek Lech (Oxford 2018) 59-68.

M. Brandl, Der richtige Stein muss es sein, in: N. Hofer - F. Sauer (eds.), Ins wilde Längental, Steinzeitjäger und Almwirtschaft im Kühtai, Tirol. Archäologie aktuell 2, 2018, 68-69.

C. Burke - P. M. Day - E. Alram-Stern - K. Demakopoulou - A. Hein, Crafting and Consumption Choices: NeolithicEarly Helladic II Ceramic Production and Distribution, Midea and Tiryns, Mainland Greece, in: E. Alram-Stern B. Horejs (eds.), Pottery Technologies and Sociocultural Connections Between the Aegean and Anatolia During the $3^{\text {rd }}$ Millennium BC. Oriental and European Archaeology 10 (Vienna 2018) 145-160.

C. Burke-S. Spencer-Wood, Crafting a History. Introduction to Crafting in the World, in: C. Burke-S. Spencer-Wood (eds.), Crafting in the World. Materiality in the Making (New York 2018) 1-16.

G. Ruß-Popa, Der Gebrauch von Schaffell in der mitteleuropäischen urgeschichtlichen Kleidung, Annalen des Naturhistorischen Museums, Serie A, vol. 120, 2018, 157-176.

S. Spencer-Wood - C. Burke, Epilogue. The Future of Craft Research, in: C. Burke - S. Spencer-Wood (eds.), Crafting in the World. Materiality in the Making (New York 2018) 255-287.

O. Schmitsberger - M. Penz, Klippen, Bergbau, Schlagabfällle - Neu entdeckte Radiolarit-Abbaustellen im Lainzer Tiergarten in Wien mit einem ersten Überblick über die Fundstellen in der „Bergbauzone Tiergarten“, Fundort Wien 21, 2018, 120-146.

O. Schmitsberger - M. Penz, Wien 13, Lainzer Tiergarten (Südostbereich) - Dorotheer und Inzersdorfer Wald (Fundchronik-Kurzbericht), Fundort Wien 21, 2018, 222.

O. Schmitsberger - M. Penz - M. Brandl, BergbauLandschaftWien - an der Schnittstelle von Geologie und Archäologie: Die St. Veiter Klippenzone als Rohstofflieferant im Neolithikum (Doppelposter). WGM - Veranstaltung „Wissen für Wien“, Wappensaal im Rathaus Wien, 20.11.2018. http://wgm.wien.at/Poster.207.0.html.

\section{Across Ancient Borders and Cultures}

I. Adenstedt, The Fortifications of the Pharaonic Town on Sai Island: A reinvestigation, in: J. Budka - J. Auenmüller (eds.), From Microcosm to Macrocosm. Individual households and cities in Ancient Egypt and Nubia (Leiden 2018) 135-146.

J. Budka - J. Auenmüller, From Microcosm to Macrocosm. Individual households and cities in Ancient Egypt and Nubia (Leiden 2018) (https://www.sidestone.com/books/from-microcosm-to-macrocosm\#).

J. Budka, with an appendix by Giulia d'Ercole, Egyptian pottery from the New Kingdom temple town of Sai Island, in: R. David (ed.), Egyptian pottery in ancient Sudan: imports, imitations and influences, Cahiers de la céramique égyptienne 11, 2018, 107-133.

J. Budka, Individual Households and Cities in Ancient Egypt and Nubia: A short summary of the state-of-the-art, in: J. Budka - J. Auenmüller (eds.), From Microcosm to Macrocosm. Individual households and cities in Ancient Egypt and Nubia (Leiden 2018) 13-28. 
J. Budka, AcrossBorders: Five seasons of work in the Pharaonic town, Sai Island, in: J. Budka - J. Auenmüller (eds.), From Microcosm to Macrocosm. Individual households and cities in Ancient Egypt and Nubia (Leiden 2018) $113-126$.

J. Budka, Pots \& People: Ceramics from Sai Island and Elephantine, in: J. Budka - J. Auenmüller (eds.), From Microcosm to Macrocosm. Individual households and cities in Ancient Egypt and Nubia (Leiden 2018) 147-170.

J. Budka, Tomb 26 in Cemetery SAC5 on Sai Island, in: J. Budka - J. Auenmüller (eds.), From Microcosm to Macrocosm. Individual households and cities in Ancient Egypt and Nubia (Leiden 2018) 185-196.

J. Budka, Sai in the New Kingdom. An ancient Egyptian outpost in Sudan, Current World Archaeology 88, 2018, $22-28$.

J. Budka, Palaces in so-called Nubian temple towns: A reassessment, in: M. Bietak - S. Prell (eds.), Ancient Egyptian and Ancient Near Eastern Palaces. Volume I. Proceedings of the Conference on Palaces in Ancient Egypt, held in London $12^{\text {th }}-14^{\text {th }}$ June 2013, Contributions to the Archaeology of Egypt, Nubia and the Levant 5 (Vienna 2018) $251-273$

J. Budka, The Urban Landscape of Upper Nubia (Northern Sudan) in the Second Millennium BC, in: B. Horejs - Ch. Schwall - V. Müller - M. Luciani - M. Ritter - M. Guidetti - R. B. Salisbury - F. Höflmayer - T. Bürge (eds.), Proceedings of the $10^{\text {th }}$ International Congress on the Archaeology of the Ancient Near East, $25^{\text {th }}-29^{\text {th }}$ April 2016, Vienna, vol. 2 (Wiesbaden 2018) 175-189.

J. Budka, The fortified pharaonic town on Sai Island: new results from current fieldwork (2013-2014), in: M. Honegger (ed.), Nubian Archaeology in the XXI ${ }^{\text {st }}$ Century 2014, Proceedings of the Thirtheenth International Conference for Nubian Studies, Neuchâtel, $1^{\text {st }-6^{\text {th }}}$ September 2014, Orientalia Lovaniensia Analecta 273 (Leuven 2018) 293-300.

\section{Ankh-Hor Project}

J. Budka, Padihorresnet C und andere Beamte der Spätzeit im östlichen Teil des Asasif, in: A. I. Blöbaum M. Eaton-Krauss - A. Wüthrich (eds.), Pérégrinations avec Erhart Graefe. Festschrift zu seinem 75. Geburtstag, Ägypten und Altes Testament 87 (Münster 2018) 103-114.

\section{The Enigma of the Hyksos}

M. Bietak, The Giparu of Ur as a Paradigm for Gender-Related Temple Types in the Ancient Near East, in: Eretz Israel 33, The Lawrence Stager Memorial Volume (Jerusalem 2018) 9*-24*.

M. Bietak - C. von Rüden, Contact Points: Avaris and Pi-Ramesse, in: J. Spier - T. Potts - S. Cole (eds.), Beyond the Nile: Egypt and the Classical World, The Paul Getty Museum (Los Angles 2018) 18-23.

M. Bietak, The Many Ethnicities of Avaris: Evidence from the northern borderland of Egypt, in: J. Budka - J. Auenmüller (eds.), From Microcosm to Macrocosm: Individual Households and Cities in Ancient Egypt and Nubia (Leiden 2018) 73-92.

M. Bietak, Introduction to Palaces in Egypt: What they tell us about the Ruler, Administration and Culture, in: M. Bietak - S. Prell (eds.), Ancient Egyptian and Ancient Near Eastern Palaces, vol. I, Egypt, Contributions to the Archaeology of Egypt, Nubia and the Levant 5 (Vienna 2018) 23-38.

M. Bietak, A Thutmosid Palace Precinct at Peru-Nefer (Tell el-Dab'a), in: M. Bietak - S. Prell (eds.), Ancient Egyptian and Ancient Near Eastern Palaces, vol. I, Egypt, Contributions to the Archaeology of Egypt, Nubia and the Levant 5 (Vienna 2018) 231-257.

M. Bietak, Book review: Anna-Latifa Mourad, Rise of the Hyksos, Egypt and the Levant from the Middle Kingdom to the Early Second Intermediate Period, Oxford 2015: Archaeopress Egyptology, 11, Bibliotheca Orientalis 75, 3-4, 2018, 227-247.

M. Bietak, Book review: James K. Hoffmeier (ed.), Excavations in North Sinai: Tell el-Borg I, edited by James K. Hoffmeier, with contributions by Kenneth A. Kitchen, James E. Knudstad, Rexine Hummel, Stuart Swiny, Catherine Duff, Gregory D. Mumford, Thomas Herbich, Stephen O. Moshier, and others. Winona Lake, Indiana 2014, in Palestine Exploration Quarterly 150 (2018), DOI:10.1080/00310328.2018.1424414.

E. Priglinger, The Role of Migration Theory in Egyptology, Journal of Ancient Egyptian Interconnections 19, 2018, $22-42$. 
Eva Alram-Stern

iD https://orcid.org/0000-0002-4921-3061

Edeltraud Aspöck

https://orcid.org/0000-0001-7535-2316

Bettina Bader

https://orcid.org/0000-0003-2497-2894

Marlon Bas

https://orcid.org/0000-0001-7236-2404

Benedikt Biederer

iD https://orcid.org/0000-0003-2117-2605

Manfred Bietak

https://orcid.org/0000-0003-2867-8617

Mario Börner

https://orcid.org/0000-0002-7601-3487

Michael Brandl

https://orcid.org/0000-0002-0214-8231

Gottfried Brem

iD https://orcid.org/0000-0002-7522-0708

Julia Budka

https://orcid.org/0000-0002-9805-4394

Teresa Bürge

https://orcid.org/0000-0002-5875-365X

Clare Burke

(iD) https://orcid.org/0000-0001-7117-5930

Birgitta Eder

iD https://orcid.org/0000-0001-8386-5541

Thomas Einwögerer

https://orcid.org/0000-0003-0612-906X

Michaela Fritzl

https://orcid.org/0000-0002-9858-3181

Mario Gavranovic

https://orcid.org/0000-0001-6249-1819

Monika Griebl

(iD) https://orcid.org/0000-0002-3552-7115

Manfred Hainzmann

https://orcid.org/0000-0002-9727-8767

Felix Höflmayer

https://orcid.org/0000-0002-6784-0536
Barbara Horejs

https://orcid.org/0000-0002-4818-6268

Jasmin Huber

https://orcid.org/0000-0002-6264-4595

Reinhard Jung

https://orcid.org/0000-0001-7618-3761

Eleftheria Kardamaki

https://orcid.org/0000-0003-3450-3784

Holger Kockelmann

https://orcid.org/0000-0002-8796-4325

Karin Kopetzky

https://orcid.org/0000-0002-4707-4272

Vera Müller

https://orcid.org/0000-0002-9736-7399

Pany-Kucera

https://orcid.org/0000-0003-4140-3220

Elisa Perego

https://orcid.org/0000-0002-7197-3972

Katharina Rebay-Salisbury

https://orcid.org/0000-0003-0126-8693

Annalisa Rumolo

https://orcid.org/0000-0002-0861-0773

Gabriela Ruß-Popa

https://orcid.org/0000-0001-8492-6238

Roderick B. Salisbury

https://orcid.org/0000-0003-3773-5337

Martina Simon

https://orcid.org/0000-0003-4646-5594

Barbara Wallner

https://orcid.org/0000-0003-4159-0695

Lukas Waltenberger

https://orcid.org/0000-0002-9670-6117

Estella Weiss-Krejci

https://orcid.org/0000-0002-9762-2038

Annik Wüthrich

https://orcid.org/0000-0001-9665-3222 
ISBN: 978-3-903207-35-6 